\title{
THE ROLES OF NA ${ }^{+} / \mathrm{H}^{+}$EXCHANGER REGULATORY FACTOR 1 AND AQUAPORIN-1 IN THE PATHOMECHANISM OF EXPERIMENTAL ACUTE PANCREATITIS
}

Zsolt Balla, M.Sc.

Ph.D. Thesis 


\section{THE ROLES OF $\mathrm{NA}^{+} / \mathrm{H}^{+}$EXCHANGER REGULATORY FACTOR 1 AND AQUAPORIN-1 IN THE PATHOMECHANISM OF EXPERIMENTAL ACUTE PANCREATITIS}

Zsolt Balla, M.Sc.

Ph.D. Thesis

Supervisor: $\quad$ Zoltán Rakonczay Jr., M.D., Ph.D., D.Sc.

Department of Pathophysiology

University of Szeged

Szeged, Hungary

2019 


\section{Articles closely related to the subject of the thesis}

I. Pallagi P*, Balla Z*, Singh AK*, Dósa S, Iványi B, Kukor Z, Tóth A, Riederer B, Liu Y, Engelhardt R, Jármay K, Szabó A, Janovszky A, Perides G, Venglovecz V, Maléth J, Wittmann T, Takács T, Gray MA, Gácser A, Hegyi P, Seidler U, Rakonczay Z Jr. The role of pancreatic ductal secretion in protection against acute pancreatitis in mice. Crit Care Med. 2014 [IF 2014: 6.312]; 42(3):e177-88. PMID: 24368347. *The first three authors contributed equally.

II. Venglovecz V, Pallagi P, Kemény LV, Balázs A, Balla Z, Becskeházi E, Gál E, Tóth E, Zvara Á, Puskás LG, Borka K, Sendler M, Lerch MM, Mayerle J, Kühn JP, Rakonczay Z Jr, Hegyi P. The importance of aquaporin 1 in pancreatitis and its

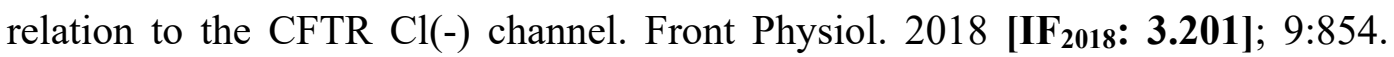
PMID: 30050452 .

\section{Articles not closely related to the subject of the thesis}

I. Rumbus Z, Toth E, Poto L, Vincze A, Veres G, Czako L, Olah E, Marta K, Miko A, Rakonczay Z Jr, Balla Z, Kaszaki J, Foldesi I, Maleth J, Hegyi P, Garami A. Bidirectional Relationship Between Reduced Blood pH and Acute Pancreatitis: A Translational Study of Their Noxious Combination. Front Physiol. 2018 [IF 2018: 3.201]; 9:1360. PMID: 30327613.

II. Balázs A, Balla Z, Kui B, Maléth J, Rakonczay Z Jr, Duerr J, Zhou-Suckow Z, Schatterny J, Sendler M, Mayerle J, Kühn JP, Tiszlavicz L, Mall MA, Hegyi P. Ductal Mucus Obstruction and Reduced Fluid Secretion Are Early Defects in Chronic Pancreatitis. Front Physiol. 2018 [IF 2018: 3.201]; 9:632. PMID: 29896115.

III. Katona M, Hegyi P, Kui B, Balla Z, Rakonczay Z Jr, Rázga Z, Tiszlavicz L, Maléth J, Venglovecz V. A novel, protective role of ursodeoxycholate in bile-induced pancreatic ductal injury. Am J Physiol Gastrointest Liver Physiol. 2016 [IF 2016: 3.468]; 310(3):G193-204. PMID: 26608189.

IV. Kui B, Balla Z, Vasas B, Végh ET, Pallagi P, Kormányos ES, Venglovecz V, Iványi B, Takács T, Hegyi P, Rakonczay Z Jr. New insights into the methodology of L-arginine-induced acute pancreatitis. PLoS One. 2015 [IF 2015: 3.057]; 10(2):e0117588. PMID: 25688985. 
V. Aranyi P, Turoczi Z, Garbaisz D, Lotz G, Geleji J, Hegedus V, Rakonczay Z, Balla Z, Harsanyi L, Szijarto A. Postconditioning in major vascular surgery: prevention of renal failure. J Transl Med. 2015 [IF 2015: 3.691]; 13:21. PMID: 25622967.

VI. Maléth J, Balázs A, Pallagi P, Balla Z, Kui B, Katona M, Judák L, Németh I, Kemény LV, Rakonczay Z Jr, Venglovecz V, Földesi I, Pető Z, Somorácz Á, Borka K, Perdomo D, Lukacs GL, Gray MA, Monterisi S, Zaccolo M, Sendler M, Mayerle J, Kühn JP, Lerch MM, Sahin-Tóth M, Hegyi P. Alcohol disrupts levels and function of the cystic fibrosis transmembrane conductance regulator to promote development of pancreatitis. Gastroenterology. 2015 [IF 2015: 18.187]; 148(2):42739.e16. PMID: 25447846.

VII. Kui B, Balla Z, Végh ET, Pallagi P, Venglovecz V, Iványi B, Takács T, Hegyi P, Rakonczay Z Jr. Recent advances in the investigation of pancreatic inflammation induced by large doses of basic amino acids in rodents. Lab Invest. 2014 [IF 2014: 3.676]; 94(2):138-49. PMID: 24365745.

VIII. Onody P, Stangl R, Fulop A, Rosero O, Garbaisz D, Turoczi Z, Lotz G, Rakonczay Z Jr, Balla Z, Hegedus V, Harsanyi L, Szijarto A. Levosimendan: a cardiovascular drug to prevent liver ischemia-reperfusion injury? PLoS One. 2013 [IF 2013: 3.534]; 8(9):e73758. PMID: 24040056.

IX. Garbaisz D, Turóczi Z, Fülöp A, Rosero O, Arányi P, Ónody P, Lotz G, Rakonczay Z, Balla Z, Harsányi L, Szijártó A. [Postconditioning can reduce long-term lung injury after lower limb ischemia-reperfusion]. Magy Seb. 2013 [IF 2018: 0.000]; 66(3):146-54. PMID: 23782601.

X. Garbaisz D, Turoczi Z, Fulop A, Rosero O, Aranyi P, Onody P, Lotz G, Rakonczay Z, Balla Z, Harsanyi L, Szijarto A. Therapeutic option for managing lung injury induced by infrarenal aortic cross-clamping. J Surg Res. 2013 [IF 2013: 2.121]; 185(1):469-76. PMID: 23751804.

XI. Czigány Z, Turóczi Z, Bulhardt O, Hegedüs V, Lotz G, Rakonczay Z, Balla Z, Harsányi L, Szijártó A. [Remote ischemic conditioning: short-term effects on rat liver ischemic-reperfusion injury]. Orv Hetil. 2012 [IF 2012: 0.000]; 153(40):157987. Hungarian. PMID: 23022881. 
XII. Biczó G, Hegyi P, Dósa S, Balla Z, Venglovecz V, Iványi B, Wittmann T, Takács T, Rakonczay Z Jr. Aliphatic, but not imidazole, basic amino acids cause severe acute necrotizing pancreatitis in rats. Pancreas. 2011 [IF 2011: 2.386]; 40(3):486-7. PMID: 21412124.

Number of full publications:

14

Cumulative impact factor:

56.038 


\section{Table of contents}

1 LIST OF ABBREVIATIONS

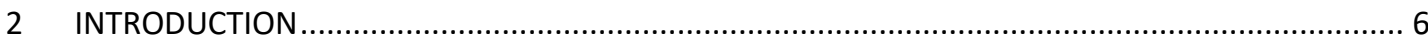

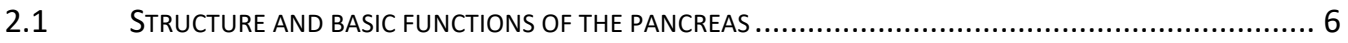

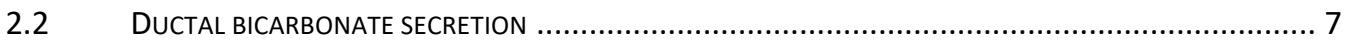

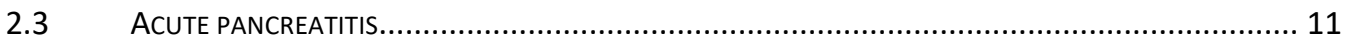

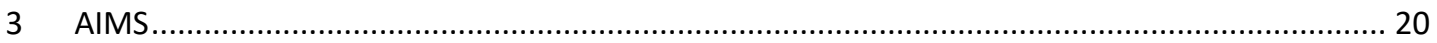

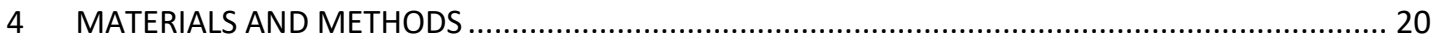

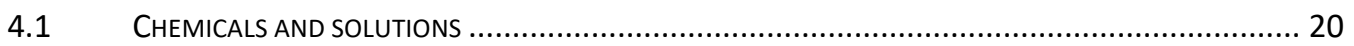

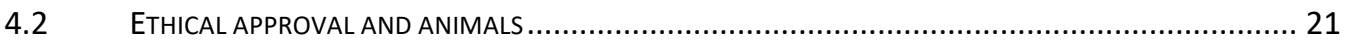

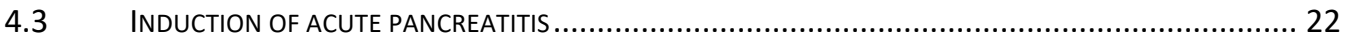

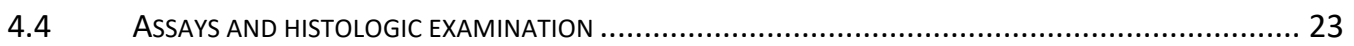

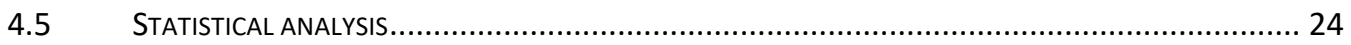

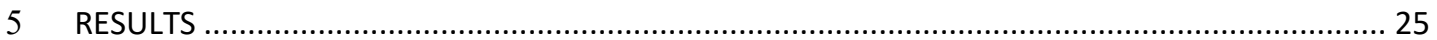

5.1 Cerulein-INDUCED PANCREATITIS IS MORE SEVERE IN NHERF-1-KNOCK-OUt MICE ..................... 25

5.2 INTRADUCTAL ADMINISTRATION OF SODIUM-TAUROCHOLATE CAUSES MORE EXTENSIVE ACINAR CELL NECROSIS IN NHERF-1-KO COMPARED TO WILD-TYPE MICE ............................................ 31

5.3 THE SEVERITY OF ACUTE PANCREATITIS IS AGGRAVATED IN AQUAPORIN-1 KO MICE...................... 34

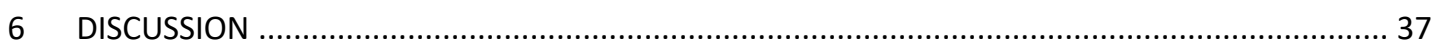

6.1 THE ROLE OF NHERF-1 IN ACUTE EXPERIMENTAL PANCREATITIS ......................................... 38

6.2 THE ROLE OF AQUAPORIN-1 CHANNEL IN ACUTE EXPERIMENTAL PANCREATITIS........................... 40

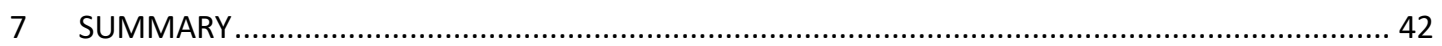

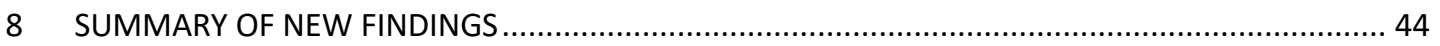

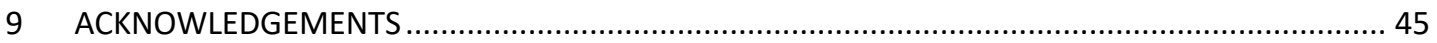

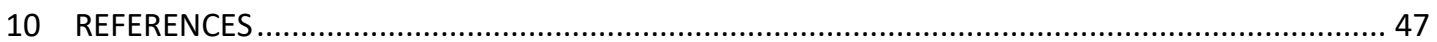

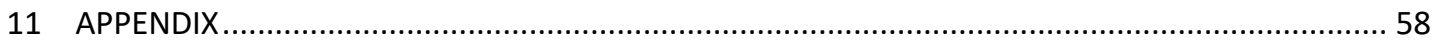




\section{List of abbreviations}

AP: acute pancreatitis

$\mathrm{AQP}:$ aquaporin

CF: cystic fibrosis

CFTR: cystic fibrosis transmembrane conductance regulator $\mathrm{Cl}^{-}$channel $\mathrm{HCO}_{3}^{-}$: bicarbonate

HSP: heat shock protein

IкB: inhibitor kappa-B

i.d.: intraductal

i.p.: intraperitoneal

IL-1 $\beta$ : interleukin-1 $\beta$

KO: knock-out

MPO: myeloperoxidase

NHE3: $\mathrm{Na}^{+} / \mathrm{H}^{+}$exchanger-3

NHERF-1: $\mathrm{Na}^{+} / \mathrm{H}^{+}$exchanger regulatory factor-1

NF-кB: nuclear factor kappa B

PS: physiological saline

WT: wild-type 


\section{INTRODUCTION}

\subsection{Structure and basic functions of the pancreas}

The pancreas is made up of exocrine and endocrine parts. The exocrine pancreas secretes approximately 1.5-2 liters of isotonic fluid per day, which is rich in bicarbonate $\left(\mathrm{HCO}_{3}^{-}\right)$and contains digestive enzymes. The exocrine pancreas consists of two main cell types: acinar cells (responsible for the production of digestive enzymes) and ductal cells (responsible for bicarbonate and fluid secretion), the former cells constitute the majority of glandular tissue. The ductal cells form a complex tubular network that runs through the entire gland [Argent et al. 2012] (Figure 1) and unites in an outlet duct (Wirsungianus).

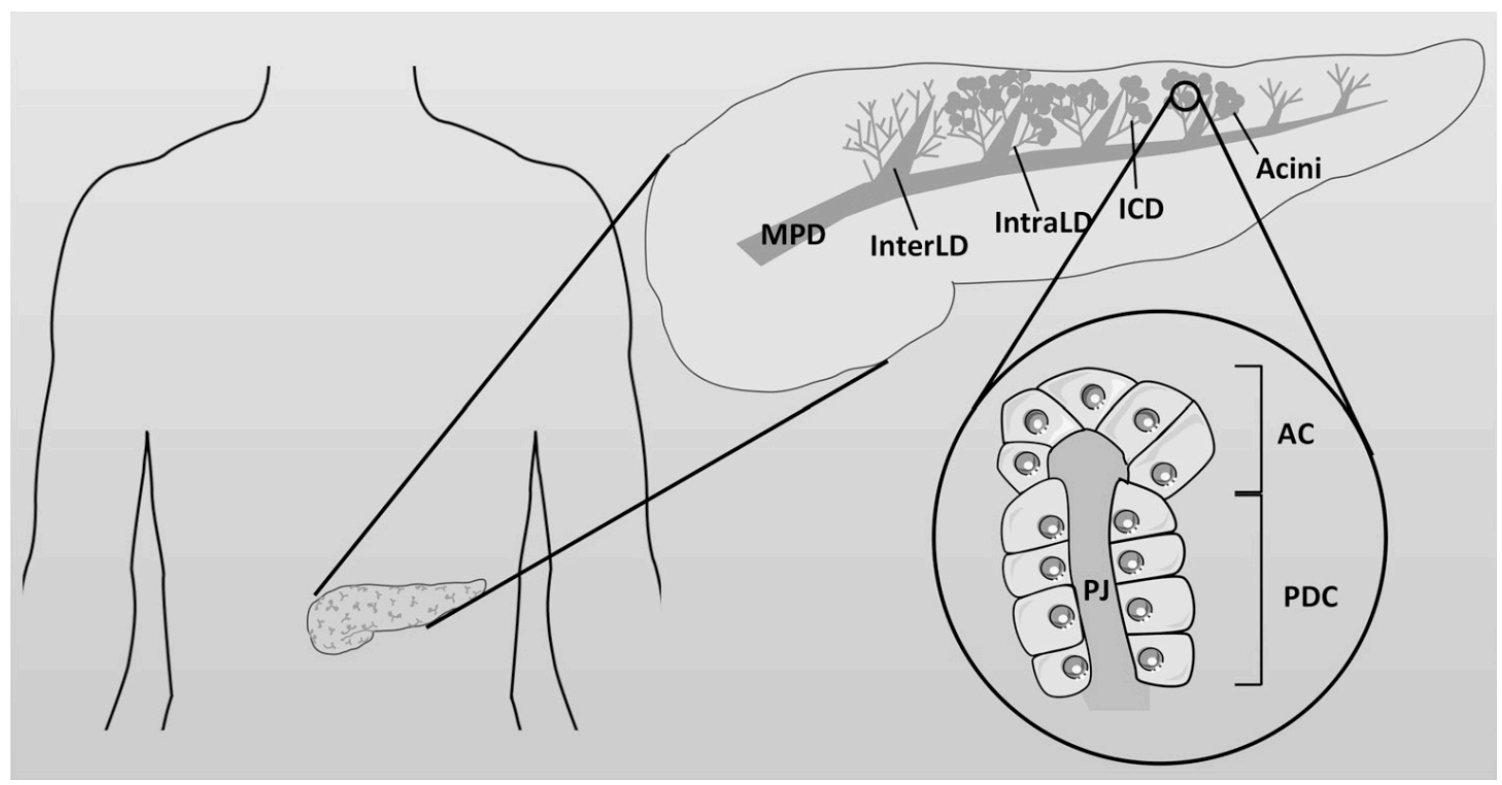

Figure 1. Simplified structure of the pancreas. The exocrine pancreas consists mainly of acini that surround a smaller central duct and open toward the duct system. Acinar cells (AC) secrete digestive enzymes into small intercalated channels (ICDs), where pancreatic ductal cells (PDCs) transmit pancreatic juice (PJ) towards the duodenum. These channels are directly connected to a growing network of intralobular (intraLD) and interlobular (interLD) ducts, and later to the major pancreatic duct [Vinciane et al. 2017]. 


\subsection{Ductal bicarbonate secretion}

The primary role of pancreatic ductal cells is the secretion of $\mathrm{HCO}_{3}^{-}$[Argent et al. 2012, Steward et al. 2005]. The first step in the secretion of $\mathrm{HCO}_{3}^{-}$is its uptake from the extracellular space. This process occurs through the basolateral membrane via the $\mathrm{Na}^{+} / \mathrm{HCO}_{3}^{-}$ cotransporter, or by diffusion of $\mathrm{CO}_{2}$, which is then converted to carbonic acid $\left(\mathrm{H}_{2} \mathrm{CO}_{3}\right)$ by carbonic anhydrase. The resulting protons are released from the cell by $\mathrm{Na}^{+} / \mathrm{H}^{+}$exchangers or $\mathrm{H}^{+}$pumps. Intracellular $\mathrm{HCO}_{3}^{-}$derived from $\mathrm{H}_{2} \mathrm{CO}_{3}$ is secreted through transporters. This is followed by the second step of $\mathrm{HCO}_{3}^{-}$secretion: bicarbonate exits ductal cells via cystic fibrosis transmembrane conductance regulator (CFTR) and solute carrier anion exchangers (SLC26A3, or down-regulated in adenoma, DRA; or SLC26A6, putative anion transporter-1, PAT-1) and is secreted into the luminal space.

In contrast with the well-understood role of digestive enzymes, the functions and processes of pancreatic electrolyte secretion have not yet been clearly described, although it surely facilitates the transport of zymogens to the small intestine and contributes to the neutralization of stomach acid in order to provide optimal $\mathrm{pH}$ for digestive enzymes in the duodenum. This is significant because maintaining a neutral or alkaline luminal $\mathrm{pH}$ is crucial for the membrane dynamics of acinar cells and, consequently, for the exocytosis of zymogen granules [Freedman et al. 2001]. Previous studies have shown that lower extracellular pH enhances secretagogue-induced zymogen activation in acinar cells [Bhoomagoud et al. 2009]. Recent studies have also shown, as a result of the Pancreatic Research Group in Szeged, that proper $\mathrm{HCO}_{3}^{-}$secretion is essential to prevent autoactivation of trypsin in the ductal tree. Moreover, trypsin itself can reduce apical proteinase-activated receptor-2 by activating CFTR-dependent $\mathrm{HCO}_{3}^{-}$secretion in ductal cells [Pallagi et al. 2011], leading to further trypsin autoactivation. Thus, the reduction of ductal $\mathrm{HCO}_{3}^{-}$secretion is of paramount importance in the preservation of intact pancreatic structure [Hegyi et al. 2016] (Figure 2). 


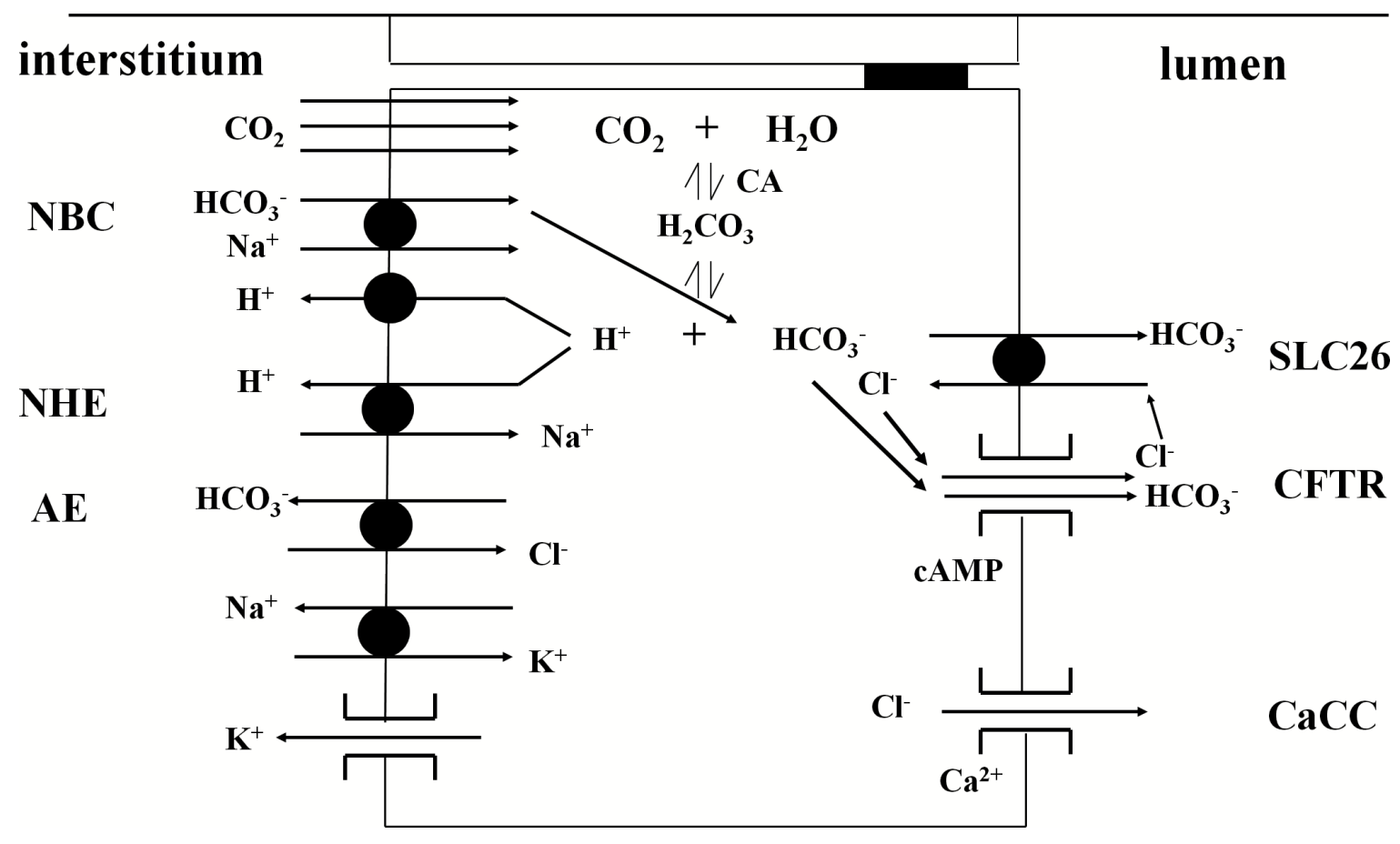

Figure 2. Schematic diagram of ion transport systems in pancreatic ductal epithelial cells. AE, anion exchanger 2 [Pallagi et al. 2015].

\subsubsection{The roles of CFTR and NHERF-1 in ductal secretion}

CFTR is expressed in the apical membrane of ductal cells, but it is absent in acinar cells [Crawford et al. 1991, Marino et al. 1991]. Its proper function is essential for pancreatic ductal $\mathrm{HCO}_{3}^{-}$and fluid secretion [Steward et al. 2009]. The importance of CFTR can be illustrated by CF, in which the lack of CFTR-dependent fluid secretion has been shown to cause nearly complete glandular destruction at birth in $85 \%$ of patients [Hegyi et al. 2016, Kopelman et al. 1985].

The intercalated and/or intralobular and interlobular ductal cells express CFTR (to varying degrees depending on the species) and are responsible for producing an isotonic, highly alkaline fluid with a $140 \mathrm{mM} \mathrm{NaHCO} 3$ content. However, the composition of the secretion may vary from species to species depending on the flow rate [Argent et al.2012, Novak et al. 2013, Steward et al. 2005]. At maximum velocity, $\mathrm{HCO}_{3}^{-}$concentration is about $140 \mathrm{mM}$ in most species with the exception of rats and mice, where the maximum is about $70 \mathrm{mM}$ [Argent et al. 2012, Novak et al. 2013]. 
The major physiological regulator of pancreatic $\mathrm{HCO}_{3}^{-}$secretion is secretin, which is released from the intestinal " $\mathrm{S}$ " neuroendocrine cells, mainly in response to acidic gastric contents. By binding to the receptors on ductal cells, secretin stimulates the activation of protein kinase A, which leads to an elevation of intracellular cAMP levels and consequently causes an increase in CFTR activity through channel phosphorylation.

$\mathrm{Na}^{+} / \mathrm{H}^{+}$exchanger regulatory factor-1 (NHERF-1, also known as Ezrin binding protein-50, EBP50) is a cytosolic regulatory protein. NHERF-1 promotes the formation of multiple multiprotein-associated complexes with postsynaptic density-95/disc-large/zonula occludens-1 (PDZ) and ezrin-radixin-moesin (ERM) binding domains [Brône et al. 2005]. The adapter protein has been shown to bind to CFTR and $\mathrm{Na}^{+} / \mathrm{H}^{+}$exchanger-3 with PDZ-binding motifs. NHERF-1 also affects many other proteins, such as regulation of kidney phosphate transport [Blaine et al. 2011], hepatic Mrp2 expression [Li et al. 2010], and function, protein kinase D activity [Kunkel et al. 2009], $\beta 2$-adrenergic receptor [Wheeler et al. 2007, or opioid kappa receptor transport [Liu-Chen 2004]. NHERF-1 is also involved in pathophysiological processes. Based on small intestine and sigmoid biopsies, the change in transepithelial sodium and fluid transport in inflammatory bowel disease is partly due to reduced NHERF1 expression [Liu-Chen 2004]. In NHERF-1 knock-out (KO) mice, increased phosphate secretion of the renal tubules has been observed, leading to hypophosphatemia [Prié et al. 2004]. The role of NHERF-1 in the pancreas is not yet well understood. However, deletion of NHERF-1 resulted in gross mislocalization of CFTR, causing marked reduction in pancreatic ductal fluid and bicarbonate secretion [Pallagi et al. 2014].

\subsubsection{Role of SLC26A3/A6 in ductal bicarbonate secretion}

In the late 1990's, the SLC26 gene family emerged as a group of anion exchangers that were structurally distinct from the classical anion exchangers (now referred to as SLC4) gene family. Ten family members (SLC26A1-A11, A10 is a pseudogene) have been cloned to date. Most of them act as anion exchangers in the kidney, gut and pancreas; however, SLC26A5 (prestin) is the motor protein in the outer hair cells of the inner ear, SLC26a 7 and SLC26a9 act as $\mathrm{Cl}^{-}$channels. Strong candidates for the apical anion exchanger in pancreatic duct cells are SLC26A3 (down regulated in adenoma, DRA) and 
even more so SLC26A6 (putative anion transporter-1, PAT-1). DRA is mutated in congenital chloride diarrhea and is expressed at high level at the luminal membrane of the colon. It was originally identified as a chloride transporter, but subsequent studies have shown that it functions as a $\mathrm{Cl}^{-} / \mathrm{HCO}_{3}^{-}$exchanger. DRA belongs to the family of SLC26 transporters: it is designated SLC26A3 and is expressed in several epithelia. Notably SLC26A3 functions as an electrogenic $2 \mathrm{Cl}^{-} / 1 \mathrm{HCO}_{3}^{-}$exchanger. PAT-1 was originally identified in a search for novel SLC26 transporters, and as the oxalate transporter in the renal proximal tubule. SLC26A6 and its two splice variants are ubiquitously expressed, with high levels in the luminal membrane of the pancreatic duct. SLC26A6 functions as a $2 \mathrm{HCO}_{3}^{-} / 1 \mathrm{Cl}^{-}$exchanger. Although some laboratories have examined the characteristics of $\mathrm{HCO}_{3}^{-}$transport in intact pancreatic ducts isolated from SLC26a6 KO mice [Ishiguro et al. 2007], further investigation is required to prove the role of SLC26 anion exchangers in ductal fluid and $\mathrm{HCO}_{3}^{-}$secretion.

\subsubsection{Role of aquaporins in ductal fluid secretion}

Aquaporins (AQPs) are small membrane proteins whose primary function is to help transport water molecules. Recent studies have highlighted their essential role in specific regulatory processes [Madeira et al. 2015, Ribatti et al. 2014, Rodriguez et al. 2011]. To date, 13 AQP isoforms have been identified in mammals, and some show species-specific expression patterns in the pancreas. AQP1, -5, -8, and -12 are also present in the human pancreas [Burghardt et al. 2003, Furuya et al. 2002, Hurley et al. 2001, Itoh et al. 2005, Tani et al. 2001]. AQP1 is the first AQP described that is only permeable to water [Preston etal. 1992]. The presence of AQP1 has been previously demonstrated in the apical and lateral plasma membranes of centrifugal cells and the apical and basolateral membranes of intercalary and intralobular ductal cells [Burghardt et al.2003, Furuya et al. 2002]. AQP5 has been proven to be an aquaglyceroporin that aids in the transport of water along with glycerol, urea, and other small solutes. The expression of AQP5 was not detected in the centroacinar cells but only in the apical plasma membrane of the intercalated ducts [Burghardt et al. 2003]. The colocalization of AQP1 and -5 with CFTR on the apical membrane of the ducts is of particular interest, confirming that the channels influence 
each other's function [Burghardt et al. 2003]. AQP8 and -12, on the other hand, are localized exclusively in centroacinar cells [Hurley et al. 2001, Itoh et al. 2005, Tani et al. 2001].

Numerous studies have indicated that altered function or expression of AQPs is often associated with various diseases of the kidney, colon or salivary gland [Bedford et al. 2003, Steinfeld et al. 2001, Tsubota et al. 2001, Zhu et al. 2016].

\subsection{Acute pancreatitis}

\subsubsection{Clinical features}

\subsubsection{Incidence and etiology}

Acute pancreatitis (AP) is a sudden inflammation of the pancreas, the severity of which ranges from a mild to a severe, the latter of which sometimes has a fatal outcome.

The incidence of AP varies from country to country. In Western-type societies, it is most commonly 15-45/100 000 inhabitants/year, which is still slightly increasing [Robert et al. 2013]. AP is one of the most common gastroenterological disorders requiring hospital admission. In fact, this means 200000 hospital admissions in the US each year, costing the health care system $\$ 2-2.5$ billion.

Alcohol consumption and gallstones are responsible for the development and exacerbation of $70-80 \%$ of AP cases [Parniczky et al. 2016]. However, several other etiological factors (e.g. drugs, hypertriglyceridemia, pancreatic- or ampulla of Vater tumor, trauma, various mumps-, H1N1-, Coxsackie virus, bacterial infections) are known [Pandol et al. 2007]. In $10-20 \%$ of cases, the cause cannot be identified, thus the case is labeled idiopathic. Occasionally, AP develops after various endoscopic bile duct interventions, called postendoscopic retrograde-cholangiopancreatography (ERCP) pancreatitis.

In cholelithiasis, gallstones leaving the gallbladder may get stuck in the biliary ducts during migration, most commonly at the ampulla of Vater. The obstruction causes an increase in intraductal (i.d.) pressure in the pancreatic duct, which may contribute to the 
induction of AP. The exact cause of AP in alcohol consumption is not fully understood. Some experiments suggest that ethanol causes spasm of the sphincter of Oddi, which increases the sensitivity of acini to cholecystokinin [Gorelick etal.2003]. Ethanol and its metabolites stimulate the early activation of inactive zymogens within the acini. Also, alcohol metabolites induce acinar hypersecretion, which in effect alters the composition of the fluid secreted by the pancreas. Occasionally, the change in viscosity of the fluid may lead to the development of protein plugs, which may block the pancreatic duct itself. Thus, a blocked line may contribute to the formation of AP. Alcoholism is often not sufficient to induce AP, and other environmental factors are likely to contribute to it [Whitcomb et al. 2005]. This is also supported by the fact that AP cannot be induced in rodents by only drinking alcohol.

Thus, the development of AP is due to a variety of causes. Clearly identifying these causes is crucial to developing an appropriate therapeutic plan, but it can also reduce the recurrence of AP. In addition to the reasons mentioned above, a fat-rich-diet can also lead to AP. Accurate, rapid diagnosis is essential, especially for biliary AP complicated with cholangitis, because of the urgent need for ERCP.

\subsubsection{Classification}

In 2011, the revised Atlanta-classification was created for the most accurate diagnosis, evaluation of severity, and classification of AP. On the basis of the development and duration of organ failure, mild, moderate and severe AP can be distinguished. Approximately $75-80 \%$ of cases are mild, $15-20 \%$ moderate, and about $10 \%$ are severe. In mild AP, no local or distant complications occur. In moderate AP, local pancreatic (necrosis, pseudocyst, peripancreatic fluid) complications are present or transient distant organ failure (lung, kidney, liver, heart) appear within 48 hours, associated with inflammation. Persistent organ failure can be observed after 48 hours in severe AP, and local pancreatic complications can often be associated with it. In this case, admission to the intensive care unit is also frequent. Due to the development of diagnostic procedures and intensive care, the survival of AP is improving, but severe cases continue to have 
unacceptably high mortality rates. Patients with mild AP have a mortality rate of less than $1 \%$, it is around $5 \%$ with moderate pancreatitis, and $30 \%$ to $50 \%$ with severe AP.

The determinants of severity are not fully understood. However, the balance between proinflammatory and anti-inflammatory factors and affects the severity of inflammation of the pancreas. Recent results have shown that the predominance of pro-inflammatory factors could be explained by genetic polymorphisms of inflammatory mediators and regulatory factors, such as heat shock protein-72 (HSP-72), which ameliorates disease severity.

\subsubsection{Clinical symptoms and treatment}

One of the most common symptoms of AP is abdominal pain, usually in the epigastrium, which radiates to the back. This pain reaches its maximum within about 30 minutes, by which time it becomes almost unbearable and typically persists for 24 hours without a pain-free period(s). Very often, it is accompanied by nausea and vomiting, after which the patient does not feel relief. In parallel, fever and diarrhea, as well as its opposite, constipation due to paralytic ileus can occur often. The upper abdomen also becomes sensitive to slight physical pressure.

There is no specific therapy for AP. The treatments given to the patient are mainly symptomatic, e.g. fluid replacement, nutrition, analgesia, reduction of pancreatic secretory function when needed, and antibiotics if an appropriate indication is present. Enteral nutrition can be either nasogastric (currently under investigation) or nasojejunal (classically accepted mode of nourishment). Thus, the gastric and enteral phases of pancreatic enzyme secretion can be temporarily interrupted, reducing the autodigestive processes. Oral nutrition can be restarted when abdominal pain and inflammatory parameters improve. It is essential to distinguish between biliary pancreatitis and other forms because ERCP may be required in the former. Plasma apheresis may be required in case of AP due to hypertriglyceridemia. 


\subsubsection{Pathomechanism}

The pathomechanism of the disease is not fully understood, and unfortunately, specific therapy is still unknown. Therefore, the search for new therapeutic targets, experimental, and clinical examination of inflammation is also vital for reducing the mortality of the disease. Thus, several theories are known about the pathomechanism of inflammation, the mechanisms of which have been learned from in vivo and in vitro experiments. All of which are likely to play a role in the development of human AP.

In the pancreas, various aggressive and/or protective processes play a role in mediating the course of AP. The disease, initiated by various etiological factors, is likely to run on multiple parallel strands, which can eventually lead to inflammation of the pancreas and, in severe cases, cell death. These processes include: premature activation of

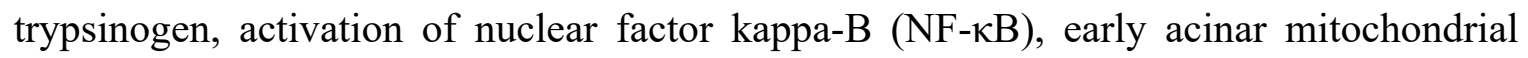
damage, the role of white blood cells, oxidative stress, and inflammatory mediators. Heat shock proteins (e.g. HSP 72) and pancreatic ductal secretion are likely to be protective.

\subsubsection{Premature activation of trypsinogen}

In the first phase of the disease, premature activation of trypsin is observed within the acinar cells and the ductal lumen. According to some hypotheses, stressors (such as ethanol or bile acids) cause $\mathrm{Ca}^{2+}$ signaling to be disturbed in acinar cells, leading to early activation of trypsinogen within the pancreas [Hofbauer et al. 1998, Saluja et al. 1997]. Under physiological conditions, trypsinogen is only activated to trypsin in the duodenum by enterokinase.

Trypsin activation is a crucial step in the process of digestive enzyme activation. Physiologically, pancreatic enzymes are synthesized and stored entirely separately from the cytoplasm, together with protease inhibitors encapsulated in zymogen granules. One idea is that the excretion of zymogen granules into the ductal space is also inhibited by acinar

damage [Halangk et al. 2000, Saluja et al. 1987]. As a result, the granules accumulate in the cell and then fuse with lysosomes until the trypsinogen is released from the granules and 
cathepsin B actives trypsinogen. Active trypsin is then able to activate other trypsinogens (autoactivation) as well as other previously inactive digestive enzymes (e.g. chymotrypsin, elastase, collagenase). It is essential to note that the activation of trypsinogen and cathepsin- $\mathrm{B}$ occurs at low $\mathrm{pH}$, and the activation of pancreatic trypsinogen increases with low $\mathrm{pH}$. It is a good indication of the complexity of the process that the protection against early trypsinogen activation in cathepsin-B knock out mice is incomplete during AP [Halangk et al. 2000].

\subsubsection{Nuclear factor-kB activation}

It is clear from the research carried out so far that the effect of NF- $\kappa \mathrm{B}$ is prominent in the pathomechanism of AP [Rakonczay et al. 2008b]. NF- $\mathrm{KB}$ is a transcription factor that plays an essential role in the regulation of many pro-inflammatory genes [Lawrence et al. 2009]. Such regulated genes include interleukins, chemokines, adhesion molecules, receptors, and enzymes whose end products contribute to the pathogenesis of inflammatory diseases

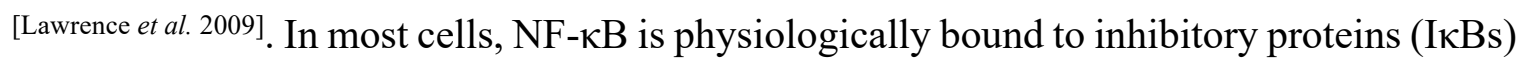
in the cytoplasm in an inactive form [Lawrence et al. 2009]. For proper stimulation, they are phosphorylated by IкBs kinases, ubiquitinated, and degraded by proteasomes. This is the process by which the nuclear localization signal of NF- $\mathrm{\kappa B}$ allows the transcription factor to be translocated to the nucleus [Lawrence et al. 2009]. There, it can bind to NF- $\kappa B$ specific $(\kappa B)$ sequences in the promoter region, thereby transactivating downstream genes [e.g. interleukin-1 $\beta$ (IL-1 $\beta$ ), interleukin-6 (IL-6), tumor necrosis factor- $\alpha$ (TNF- $\alpha$ ), plateletactivating factor, intercellular adhesion molecule-1)]. One of the primary mediators of the response to systemic and acute inflammation is TNF- $\alpha$. It is mainly produced by macrophages, neutrophils, and endothelial cells, but, importantly, acini are also capable of synthesizing TNF- $\alpha$ [Gukovskaya et al. 1997]. Thus, the activation of NF- $\kappa$ B initiates two major intracellular signaling pathways. In one case, the cytokine cascade begins, and in the other, cell apoptosis occurs. Therefore, the adequately measures levels of TNF- $\alpha$ and IL-1 $\beta$ in the serum and pancreas are proportional to the severity of AP. 


\subsubsection{Inflammatory infiltration in the pancreas}

Under stress, pancreatic acinar cells produce cytokines and chemokines, which then attract neutrophil granulocytes and monocytes to the pancreas. Through the capillary endothelium, cellular adhesion molecules (e.g., P-selectin, ICAM-1) mediate leukocyte migration. The proinflammatory mediators produced by leukocytes in the pancreatic tissue will result in progressive acinar damage and pro-inflammatory cytokine synthesis. The extent of neutrophil granulocyte infiltration can be characterized by pancreatic myeloperoxidase (MPO) activity, which varies according to the number of inflammatory cells.

\subsubsection{Mitochondrial damage, cell death}

It is well known that mitochondrial function, including ATP synthesis, is essential for cellular function. Incidentally, they also play an essential role in regulating cell death. In the absence of ATP, the cell is killed by necrosis.

In case of mitochondrial dysfunction, the intracellular signaling system of acinar cells is also "damaged". In the subapical region of the cell, the mitochondria located around the zymogen granules and the endoplasmic reticulum act as a kind of barrier to the intracellular $\mathrm{Ca}^{2+}$ signaling pathway by "uptake" of the passing $\mathrm{Ca}^{2+}$ [Tinel et al. 1999]. When mitochondria are damaged, intracellular ATP levels in the cells are also reduced. Thus, ATP-dependent processes are also inhibited, e.g., uptake of $\mathrm{Ca}^{2+}$ into the endoplasmic reticulum (by the SERCA pump) and the mitochondria, and pumping $\mathrm{Ca}^{2+}$ through the plasma membrane (using $\mathrm{Ca}^{2+}$-activated ATPase in the plasma membrane). Any of these processes may play a role in achieving toxic intracellular $\mathrm{Ca}^{2+}$ levels [Criddle et al. 2007].

Cell death is a critical step during necrotizing AP [Bhatia et al. 2004]. This process can take place in several ways, such as spontaneous (necrosis) or programmed by the cell (apoptosis, autophagy). The degree of pancreatic necrosis is decisive for the outcome of the disease. However, apoptosis of pancreatic acinar cells reduces the severity of AP. During apoptosis, the cell begins to shrink under the influence of endogenous proteases, whereby 
the chromatin matrix is condensed, and the cell organelles are unable to enter the extracellular space. Thus, dead cells are engulfed by macrophages. Also, apoptosis is accompanied by minimal inflammation. Caspase is one of the essential endogenous proteases in the development of apoptosis. Thus, the type of cell death depends on the cellular ATP concentration that is mainly affected by mitochondrial dysfunction.

\subsubsection{Oxidative stress}

Oxygen is essential for the proper functioning of the body, but it can easily damage cells when reactive oxygen species exceed the physiological level. These reactive oxygen species may be formed by reduction of the oxygen molecule by two pathways: enzymatically (e.g. by NADPH oxidase in macrophages) or non-enzymatically (a byproduct of the respiratory chain) [Malorni etal.2007]. Biologically the most important are superoxide anion, hydroxyl, and nitric oxide (NO) radicals. Reactive oxygen metabolites are quite cytotoxic. Among other things, they damage the cell membrane (peroxidation of lipids or glycoproteins), cellular proteins (carbonyl protein formation), DNA, mitochondria, or NF-kB activation. When inflammation and oxidative stress increase significantly, the activity of pancreatic antioxidant enzymes also increases. It has been shown that in the early stages of AP, the rate of synthesis of protective endogenous dismutases is significantly reduced in the gland, followed by in the increased level of free

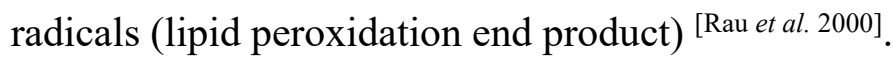

\subsubsection{Inflammatory mediators}

Proinflammatory mediators also play an essential role in AP: TNF-alpha, IL-1 $\beta$, and IL-6. TNF- $\alpha$, which plays a vital role in the inflammatory cascade, and IL-1 are also naturally occurring inhibitors (these are the soluble TNF- $\alpha$ receptor and IL-1 receptor antagonists). The role of the soluble TNF-alpha receptor is to bind TNF- $\alpha$, so it will not be able to bind to the active TNF- $\alpha$ receptor on the cell membrane. The IL-1 receptor antagonist, however, is responsible for occupying the binding site of the cytokine at the 
receptor. This is evidenced by the significant improvement in survival in experimental APs using the TNF- $\alpha$ receptor and antagonists of the IL-1 receptor [Norman et al. 1995].

\subsubsection{Heat-shock proteins}

Chaperone proteins, also known as HSPs, are essential for survival in both prokaryotic and eukaryotic organisms. The origin of the name HSP is because the cells significantly increase their production due to heat shock other than their average growth temperature. The classification of HSPs is based on their approximate molecular weight in $\mathrm{kD}$.

The role of HSPs is essential in the prevention, survival, and mitigation of the damage caused by specific stress effects, diseases. The main tasks of HSPs are to recognize damaged, partially, or fully denatured proteins. They then bind to them to stabilize them and restore their native conformation. If the extent of the damage is irreversible, then the protein is labeled and "directed" to the proteosomes.

There are several HSPs in the pancreas, the most important of which are HSP-90, $-70,-60$, and -20 , which, by their constant presence or by heat shock induction, facilitate normal functioning [Rakonczay et al. 2003, Dudeja et al. 2009].

In most cases, HSPs need harmful effects for their protective function. Therefore, it is difficult to enhance the synthesis of HSPs without having the least toxic effects on the body itself. It is immediately apparent that drugs that promote the production of HSPs may be new therapeutic options. That is why there are several studies and researches conducted by drug companies to determine the appropriate molecule and dose.

\subsubsection{Pancreatic ductal $\mathrm{HCO}_{3}^{-}$and fluid secretion}

The importance of ductal $\mathrm{HCO}_{3}^{-}$and fluid secretion is essential for the proper functioning of the pancreas [Steward et al. 2005]. The ductal epithelium prevents the diffusion of pancreatic enzymes back into the pancreatic tissue and also protects the acini as a barrier. By blocking the main pancreatic duct, i.d. pressure is increased, which facilitates the 
development of damage to the so-called ductal barrier function. Therefore, active digestive enzymes can diffuse into the tissue of the pancreas and further aggravate the disease process.

When the ductal secretion is impaired (for example, in CF), this in itself can lead to development of pancreatitis. Research in recent years has shown that crucial factors required for AP formation (e.g. bile acids, ethanol) accelerate the secretion of $\mathrm{HCO}_{3}^{-}$and fluid by the ductal cells [Venglovecz et al. 2008, Yamamoto et al. 2003]. In connection with this, the theory has been proposed that the accumulation of toxic agents (e.g. digestive enzymes) is attempted to be washed away by the pancreas. This increased hypersecretion also provides some protection against the deleterious effects of regurgitating bile acids in ampulla of Vater occlusion [Hegyi et al. 2010]. The secretion of $\mathrm{HCO}_{3}^{-}$alkalizes the lumen, thereby reducing the activation of trypsinogen, which may play a significant role in leaching active trypsin under pathological conditions [Freedman et al. 2001, Noble et al. 2008]. This process has also been demonstrated in $\mathrm{CF}$ mice, whereby correction of the luminal $\mathrm{pH}$ also repaired the defect in acinar membrane transport [Freedman et al. 2001]. Thus, it can be concluded that enhanced ductal $\mathrm{HCO}_{3}^{-}$and fluid secretion may be protective against the development of AP. 


\section{AIMS}

In this study, I had the following goals:

- to investigate the role of NHERF-1 protein in acute experimental pancreatitis

- to investigate the role of AQP1 channel in acute experimental pancreatitis.

\section{MATERIALS AND METHODS}

\subsection{Chemicals and solutions}

All chemicals were obtained from Sigma-Aldrich (Budapest, Hungary) unless indicated otherwise. Cerulein was from the American Peptide Company (Sunnyvale, CA, USA). IL-1 $\beta$ ELISA kit was purchased from R\&D Systems (Minneapolis, MN, USA). Laboratory chow was from Biofarm (Zagyvaszántó, Hungary). Amylase was determined using commercial kit (DIALAB GmbH, Neudorf, Austria, and Diagnosticum ZRt., Budapest, Hungary, respectively). Concentrated stock solutions of cerulein $(4 \mathrm{mM})$ were prepared in dimethylsulfoxide and were kept at $-20{ }^{\circ} \mathrm{C}$ until use. Right before the experiments, cerulein was diluted in physiological saline (PS). Anesthesia was performed with i.p. injection of pentobarbital (Bimeda MTC, Cambridge, Canada). CP-Ketamine $(10 \%)$ and CP-Xylazine $(2 \%)$ which were obtained from CP-Pharma-Handelsgesellschaft MBH (Burgdorf, Germany). 


\subsection{Ethical approval and animals}

Animal experiments were conducted in accordance with the Guide for the Care and Use of Laboratory Animals (2010/63/EU Directive). In addition, the experimental protocol was approved by the local Ethical Board of the University of Szeged, Hungary and also by the National Scientific Ethical Committee on Animal Experimentation (Budapest, Hungary).

Mice were housed in a typical animal care facility in regular plastic cages on 12:12 hour light-dark cycle at room temperature $\left(23 \pm 1^{\circ} \mathrm{C}\right)$ and were allowed free access to standard laboratory chow for rodents (Biofarm, Zagyvaszántó, Hungary) and drinking water. All mice were genotyped prior to the experiments. For genotyping, genomic DNA from the tail was isolated using the DirectPCR (Tail) reagent supplemented with proteinase $\mathrm{K}$ and was amplified by traditional PCR.

NHERF-1-deficient mice were originally generated and described at Duke University Medical Center. NHERF-1 mutation was congenic for the FVB/N background for at least 15 generations [Shenolikar et al. 2002]. Experiments were performed on litter-matched (12-16-week-old) wild-type (WT), and NHERF-1 knock out (KO) male mice. These animals were the gift from Prof. Ursula Seidler (Hannover Medical School, Hannover, Germany). The primer sequences for genotyping NHERF-1 mice were as follows: WT forward, 5'-TCGGGGTTGTTGGCTGGAGAC-3'; common reverse, 5'-AGCCCAACCCGCACTTACCA-3'; KO forward, 5'-AGGGCTGGCACTCTGTCG-3'. Amplicons generated by PCR were $294 \mathrm{bp}$ for the WT gene and $242 \mathrm{bp}$ for the KO gene.

Heterozygous AQP1 mice were originally generated by Ma et al. ${ }^{[1998]}$ and the KO mice were a kind gift of Prof. Alan Verkman (University of California San Francisco School of Medicine, CA, USA) and Dr. Alastair Poole (University of Bristol, UK). Experiments were performed on 12-16-week-old litter-matched WT and AQP1 KO mice. For the genotyping of AQP1 mice, we used the following primers: WT forward, 5'-AAGTCAACCTCTGCTCAGCTGGG-3', common reverse, 5'-CTCTATGGCTTCTGAGGCGGAAAG-3', and KO forward, 
5'-ACTCAGTGGCTAACAACAAACAGG-3'. Amplicons generated by PCR were 530 bp for the WT gene and $460 \mathrm{bp}$ for the KO gene.

\subsection{Induction of acute pancreatitis}

\subsubsection{Cerulein-induced pancreatitis}

AP was induced in mice by hourly (7 or 10 times) i.p. injections of cerulein (50 $\mu \mathrm{g} / \mathrm{kg}$ per injection). Control mice were given PS $(0.9 \% \mathrm{NaCl})$ solution i.p. instead of cerulein. Two hours after the final injection, mice were euthanized by pentobarbital overdose ( $85 \mathrm{mg} / \mathrm{kg}$ i.p.). Mice were exsanguinated via the inferior vena cava (NHERF-1 experiments) or via cardiac puncture (AQP1 experiments), and the pancreata were immediately removed. The pancreas was trimmed from fat and lymphatic tissue. Approximately one-quarter of the pancreatic tissue was put into a $6 \%$ neutral formaldehyde solution, and the other three quarters were dropped in liquid nitrogen and stored at $-80{ }^{\circ} \mathrm{C}$ until use. The collected blood was centrifuged at $4{ }^{\circ} \mathrm{C}$ with $2500 \mathrm{RCF}$ for $15 \mathrm{~min}$ and the serum was stored at $-20^{\circ} \mathrm{C}$ until use.

\subsubsection{Sodium-taurocholate-induced pancreatitis}

Na-taurocholate was administered i.d. as described previously by Perides et al. ${ }^{[2010]}$. Briefly, anesthesia was carried out using i.p. administration of ketamine $(125 \mathrm{mg} / \mathrm{kg})$ and xylazine $(12.5 \mathrm{mg} / \mathrm{kg})$ cocktail. The duodenum was punctured with a $0.4 \mathrm{~mm}$ diameter needle connected to a polyethylene tube after performing median laparotomy. Leakage of Na-taurocholate was prevented by temporary ligature of the biliopancreatic duct, while the proximal bile duct was temporarily occluded with a microvessel clip. $4 \%$ Na-taurocholate or PS solution was infused with an infusion pump (10 $\mu \mathrm{l} / \mathrm{min})$ (TSE System GmbH, Bad Homburg, Germany) for $5 \mathrm{~min}$. After the infusion, we removed the microvessel clip, the distal ligature, and also the injection needle. For a short time, the possibility of bleeding was monitored, and the abdominal wall and the skin were sewed. The body temperature of animals was monitored and was kept at $37^{\circ} \mathrm{C}$ until 
they woke up. Mice were exsanguinated through the inferior vena cava $24 \mathrm{~h}$ after the i.d. injection. Thereafter, all procedures were carried out as described previously in the case of cerulein-induced pancreatitis. The only difference was that all of the pancreatic tissues were fixed in a $6 \%$ neutral formaldehyde solution for histological quantification.

\subsection{Assays and histologic examination}

Amylase was measured with commercial colorimetric kit (DIALAB GmbH, Neudorf, Austria, and Diagnosticum ZRt., Budapest, Hungary) using a FLUOstar OPTIMA (BMG Labtech, Budapest, Hungary) microplate reader at $405 \mathrm{~nm}$. Acinar cell viability was determined using the $0.4 \%$ trypan-blue exclusion test. Pancreatic IL- $1 \beta$ concentrations

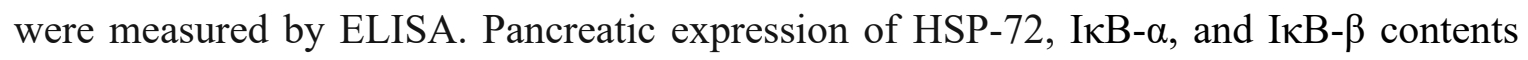
were determined by Western-blot analysis [Rakonczay etal. 2008a]. Myeloperoxidase (MPO) activity, as a marker of tissue leukocyte infiltration, was assessed by the method of Kuebler et al. ${ }^{[1996]}$.

Pancreatic injury was evaluated by semiquantitative grading of interstitial edema, leukocyte infiltration, necrosis, and in case of the Na-taurocholate model hemorrhage [Rakonczay et al. 2008a]. The extent (\%) of cell damage was confirmed by analysis with ImageJ software (NIH, Bethesda, MD, USA). The fixed pancreatic tissue was embedded in paraffin blocks, cut into $3 \mu \mathrm{m}$ thick sections, and stained for hematoxylin-eosin using standard techniques and viewed by light microscopy. A semiquantitative scoring system (0-3) in the case of AQP1 experiments was used, as we described previously [Kui et al. 2015]. Edema (0: none, 1: patchy interlobular; 2: diffuse interlobular; 3: diffuse interlobular, and interacinar), leukocytic infiltration (0: none; 1: patchy interlobular; 2: diffuse interlobular; 3: diffuse interlobular and interacinar). The rate of necrosis was expressed as a percentage of the total analyzed pancreatic area. 


\subsection{Statistical analysis}

Statistical analysis was performed by SigmaPlot (Systat Software Inc., Chicago, IL, USA). Data are presented as means \pm SEM. Both parametric (one- or two-way analysis of variance (ANOVA) and non-parametric (Kruskal-Wallis) tests were used based on the normality of data distribution (analyzed by the Shapiro-Wilk test). Post-hoc analysis (either Dunn's or Bonferroni's test) was performed according to the recommendations made by SigmaPlot. $\chi^{2}$-test was used to determine differences between groups in the proportion of mice who died. $\mathrm{P}<0.05$ was accepted as statistically significant. 


\section{RESULTS}

\subsection{Cerulein-induced pancreatitis is more severe in NHERF-1- knock-out mice}

To determine if the reduction of pancreatic secretion could influence the development of AP, NHERF-1 WT, or KO mice were given 10 hourly i.p. injections of either PS (control) or supramaximal doses of cerulein (Figure 3/A).

The control animals had normal pancreatic histology (Figure 3/A.a,d). I.p. injections of cerulein caused extensive pancreatic cell damage (Figure 3/A.b,c,e,f); the rates of necrosis (Figure 3/B), and apoptosis (Figure 3/C) were markedly higher in the NHERF-1-KO vs. WT mice. However, no significant differences were observed in the extent of interstitial edema ( $2.0 \pm 0.11$ for WT vs. $2.2 \pm 0.2$ for KO) or leukocyte infiltration $(1.72 \pm 0.08$ for WT vs. $1.95 \pm 0.13$ for $\mathrm{KO}, \mathrm{p}=0.08)$ in cerulein-treated groups.

There were also no significant differences between the WT and NHERF-1-KO control groups in all measured laboratory parameters, except for the pancreatic expression of IкB- $\beta$.

Serum amylase activities were significantly elevated in cerulein-treated vs. control WT and NHERF-1-KO mice (Figure 4/A). Importantly, amylase activity was significantly higher in the cerulein-treated NHERF-1-KO vs. WT mice. Pancreatic MPO activities were significantly increased in cerulein-treated vs. control groups, but they were not different in WT compared to KO mice exposed to cerulein (Figure 4/B). Pancreatic HSP-72 expression (a sensitive marker of tissue injury) was significantly increased in cerulein-treated vs. control groups (Figure 5/A), and significant differences were also observed between cerulein-treated WT and NHERF-1-KO groups. 
A
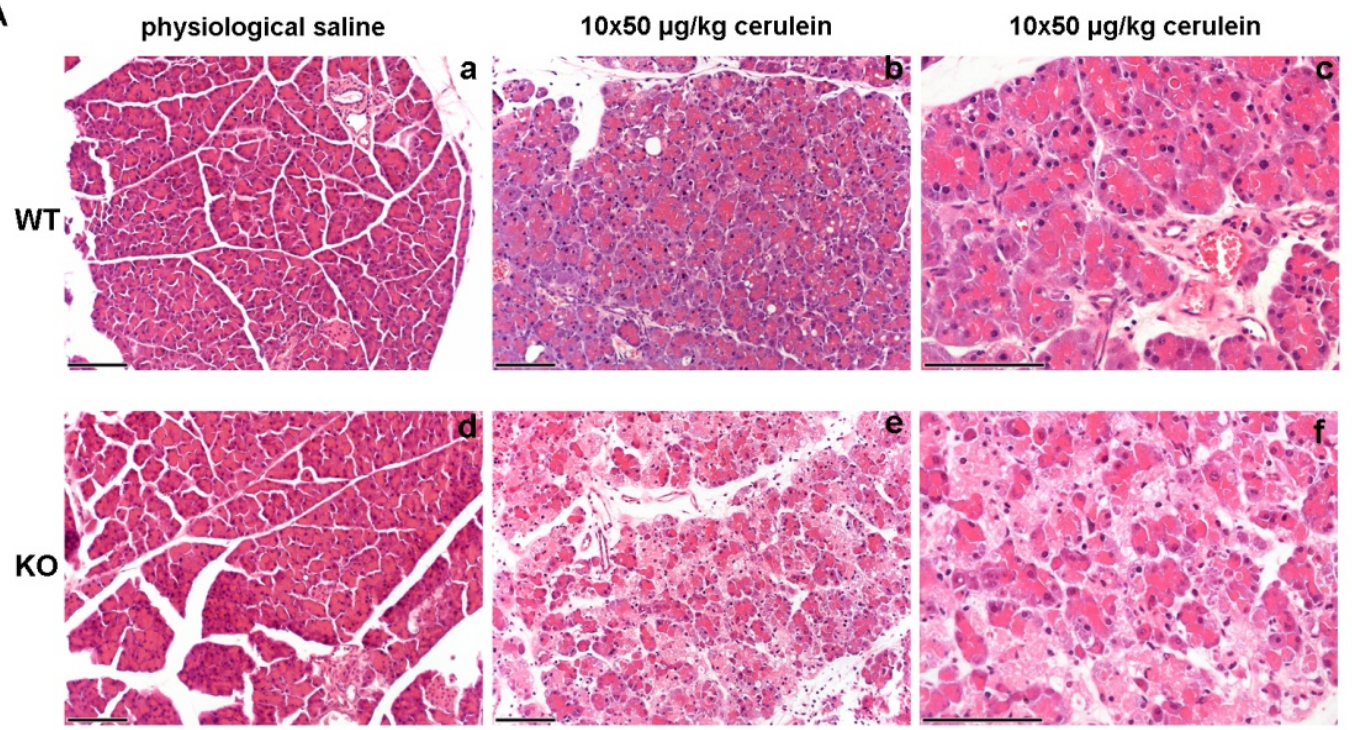

B

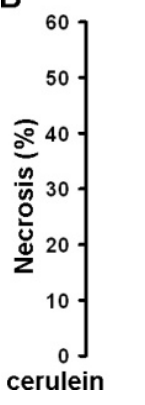

C

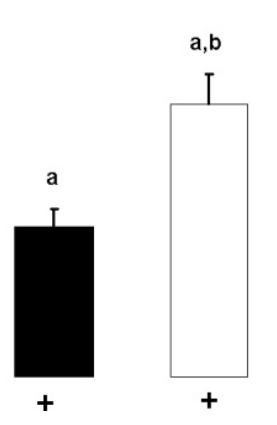

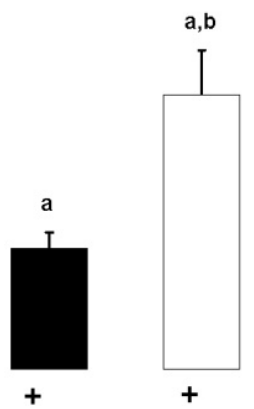

Figure 3. Histopathologic changes of the pancreas in response to intraperitoneal (i.p.) administration of $10 \times 50 \mu \mathrm{g} / \mathrm{kg}$ cerulein in wild-type (WT) and NHERF-1-knock-out (KO) mice. Acute pancreatitis was induced by administering 10 hourly i.p. injections of cerulein (50 $\mu \mathrm{g} / \mathrm{kg}$ per injection, cerulein + ). Control mice were given PS (cerulein-) instead of cerulein. Mice were exsanguinated through the inferior vena cava $12 \mathrm{~h}$ after the first i.p. injection. (A) The pictures show representative light micrographs (H\&E staining) of the pancreata of WT control (a) and ceruleintreated (b-c) and NHERF-1-KO control (d) and cerulein-treated (e-f) mice. Scale bar=100 $\mu$. The bar diagrams show the rates of pancreatic necrosis $(\boldsymbol{B})(n=9-10)$ and apoptosis $(\boldsymbol{C})(n=4-6)$. Data are shown as means $\pm S E M . P<0.05$ vs. a: the respective control group or b: vs. the WT cerulein + group. Closed columns represent WT, open columns represent NHERF-1-KO mice.

Key events in the pathogenesis of AP include premature activation of pancreatic trypsinogen [Hofbauer et al. 1998, Saluja etal. 1997] and the activation of the proinflammatory transcription factor NF-אB [Rakonczay et al. 2008b]. To exclude any potential effects of NHERF-1 deletion on early trypsinogen and NF-אB activation (regulated by IкBs), we measured pancreatic trypsin activity (Figure 5/B), and expression of IkBs (Figure 6/A-B) in mice injected i.p. with $1 \times 50 \mu \mathrm{g} / \mathrm{kg}$ cerulein. Trypsin activity was increased by about 4 -fold $0.5 \mathrm{~h}$ after the injection of cerulein compared to the control group (Figure 5/B); however, there 
were no significant differences between WT and NHERF-1-KO mice. Also, with respect to IкB- $\alpha$ expression, there were no significant differences between WT and NHERF-1-KO animals in cerulein-treated groups (Figure 6/A).

A

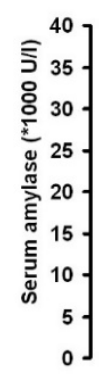

cerulein

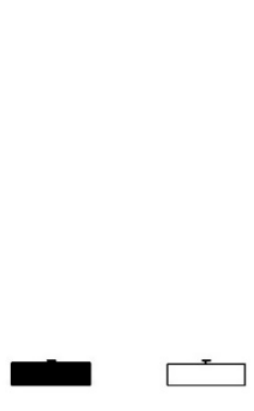

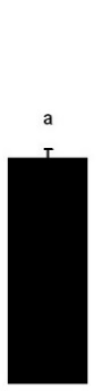

$+$

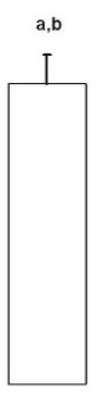

$+$
B
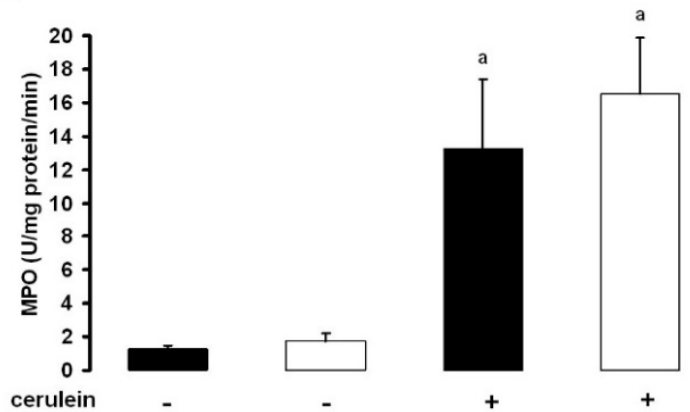

Figure 4. Effects of cerulein administration on serum amylase- and pancreatic myeloperoxidase activities in WT and NHERF-1-KO mice. Acute pancreatitis (AP) was induced in WT (closed columns) and NHERF-1-KO (open columns) mice by administering 10 hourly i.p. injections of $50 \mu \mathrm{g} / \mathrm{kg}$ cerulein (cerulein+). Control mice were given PS instead of cerulein. Mice were exsanguinated through the inferior vena cava $12 \mathrm{~h}$ after the first i.p. injection. The bar diagrams show serum amylase activity (A) and pancreatic myeloperoxidase (MPO) activity (B). Data are shown as means $\pm S E M, n=4-6 . P<0.05$ vs. a: the respective control group or b: vs. the WT cerulein + group.
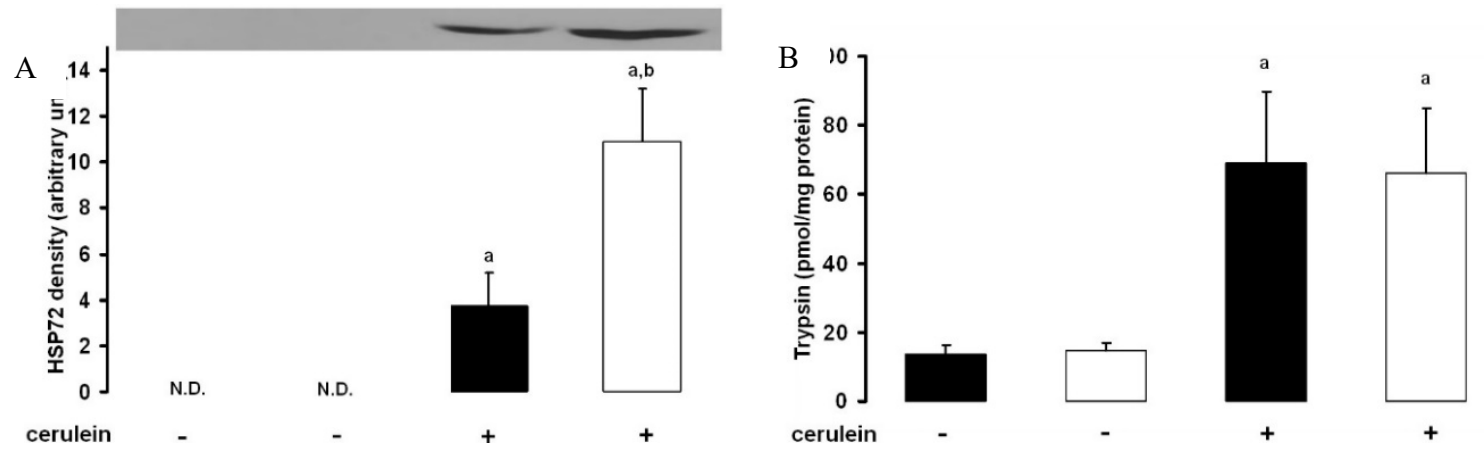

Figure 5. Severity of cerulein-induced AP and pancreatic trypsinogen activation in WT and NHERF-1-KO mice. Acute pancreatitis was induced in WT (closed columns) and NHERF-1-KO (open columns) mice by administering $1 \times 50 \mu \mathrm{g} / \mathrm{kg}$ (for measurement of trypsin activity) or 10 hourly i.p. injections of $50 \mu \mathrm{g} / \mathrm{kg}$ cerulein (cerulein + ). Control mice were given PS instead of cerulein. Mice were exsanguinated through the inferior vena cava $0.5 \mathrm{~h}$ (in case of measurement of trypsin activity) or $12 \mathrm{~h}$ after the first i.p. injection. The bar diagrams show pancreatic heat shock protein-72 (HSP-72) expression (A) and trypsin (B) activity. Data are shown as means $\pm S E M, n=4-6 . P<0.05$ vs. a: the respective control group or b: vs. the WT cerulein+ group. N.D.: not detected.

The basal level of I $\mathrm{B}-\beta$ was significantly higher in NHERF-1-KO vs. WT control mice, and no differences were observed in cerulein-treated WT and NHERF-1-KO groups 
(Figure 6/B). These data demonstrate that the difference in AP severity between WT and NHERF-1-KO mice is independent of pancreatic trypsinogen and NF- $\mathrm{BB}$ activation.

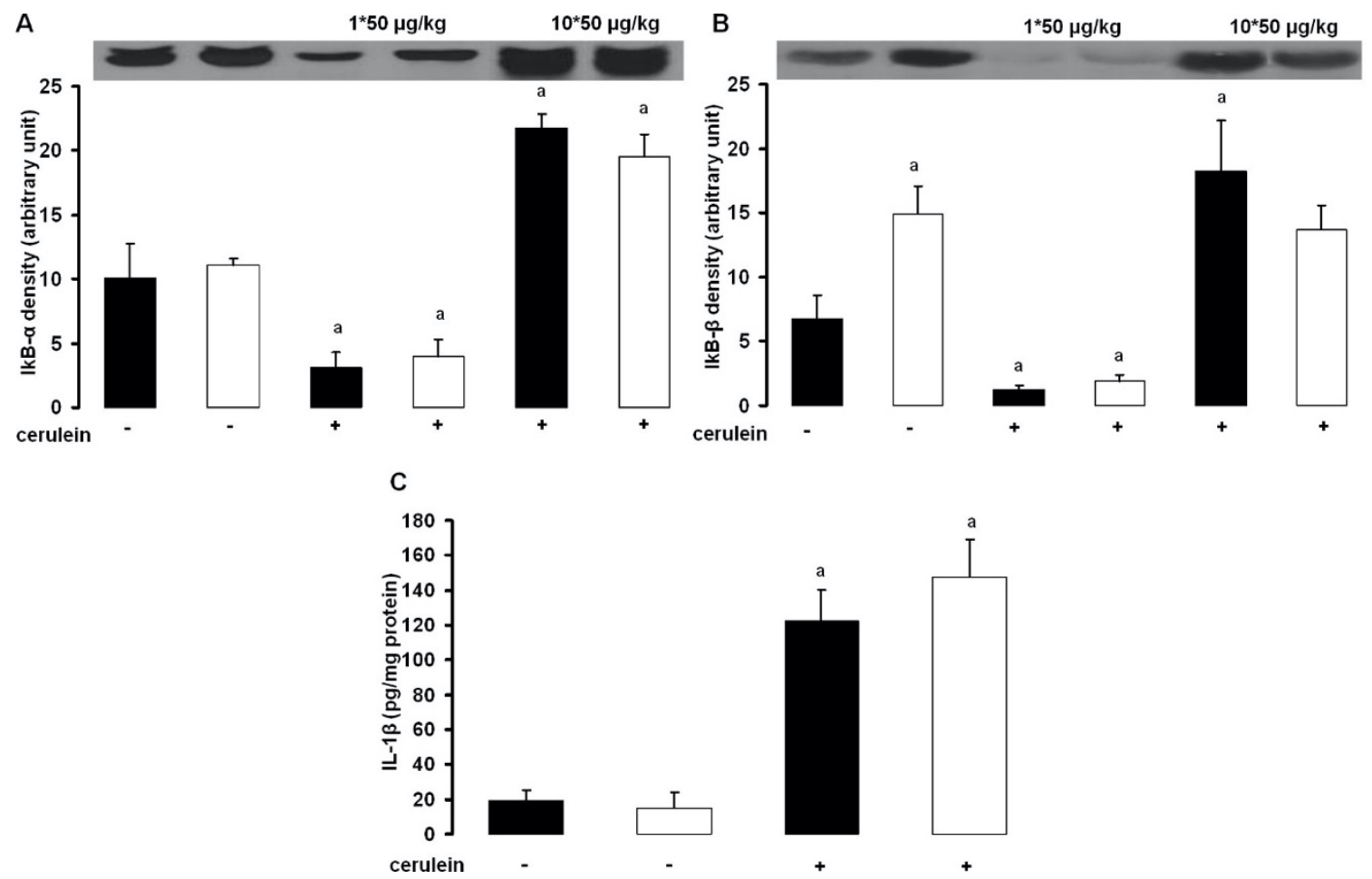

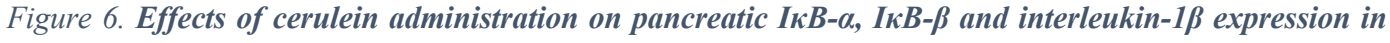
WT and NHERF-1-KO mice. Acute pancreatitis was induced by administering $1 \times 50 \mu \mathrm{g} / \mathrm{kg}$ (for measurements of

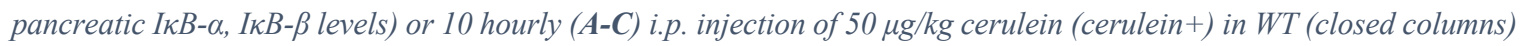
and NHERF-1-KO (open columns) mice. Control animals were given PS (cerulein-) instead of cerulein. Mice were sacrificed by exsanguination through the inferior vena cava $0.5 \mathrm{~h}$ (in case of administration of $1 \times 50 \mu \mathrm{g} / \mathrm{kg}$ cerulein) or $12 \mathrm{~h}$ after the first i.p. injection. The bar diagrams and the representative Western immunoblot analysis (A, B) of protein lysates (40 $\mu \mathrm{g} /$ lane) from the pancreas of mice, showing the expression of I $\mathrm{K} B-\alpha(\boldsymbol{A})$ and $I \kappa B-\beta(\boldsymbol{B})$. Equal loading/transfer of proteins was checked by Ponceau $S$ staining of the nitrocellulose membrane. IL-1 $\beta$ expression was determined from the pancreatic homogenates by ELISA $(\boldsymbol{C})$. Means \pm SEM for 4-6 animals are shown. $P<0.05 v$ s. a: the respective control group.

The expression of the proinflammatory cytokine IL-1 $\beta$ was significantly elevated in the pancreas of cerulein-treated vs. control WT and NHERF-1-KO mice (Figure 6/C), but there was no significant difference between the cerulein-treated WT vs. NHERF-1-KO mice. 
A

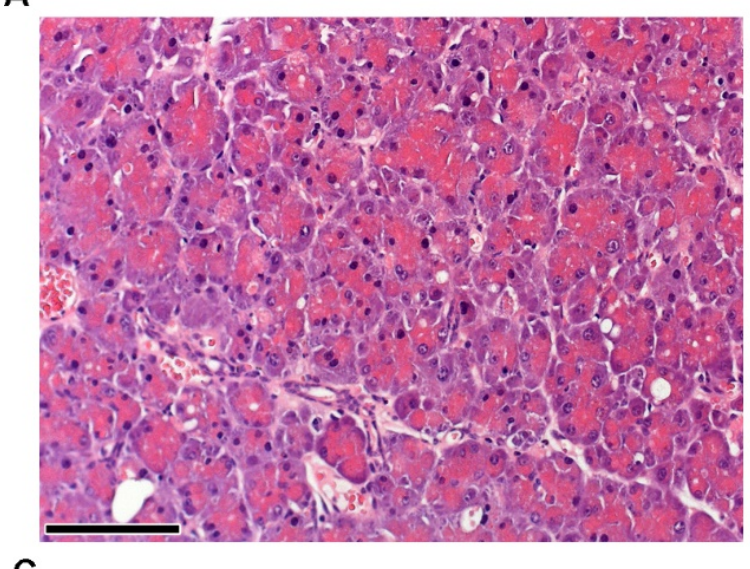

C

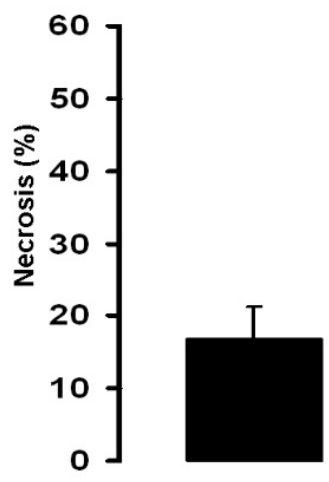

B
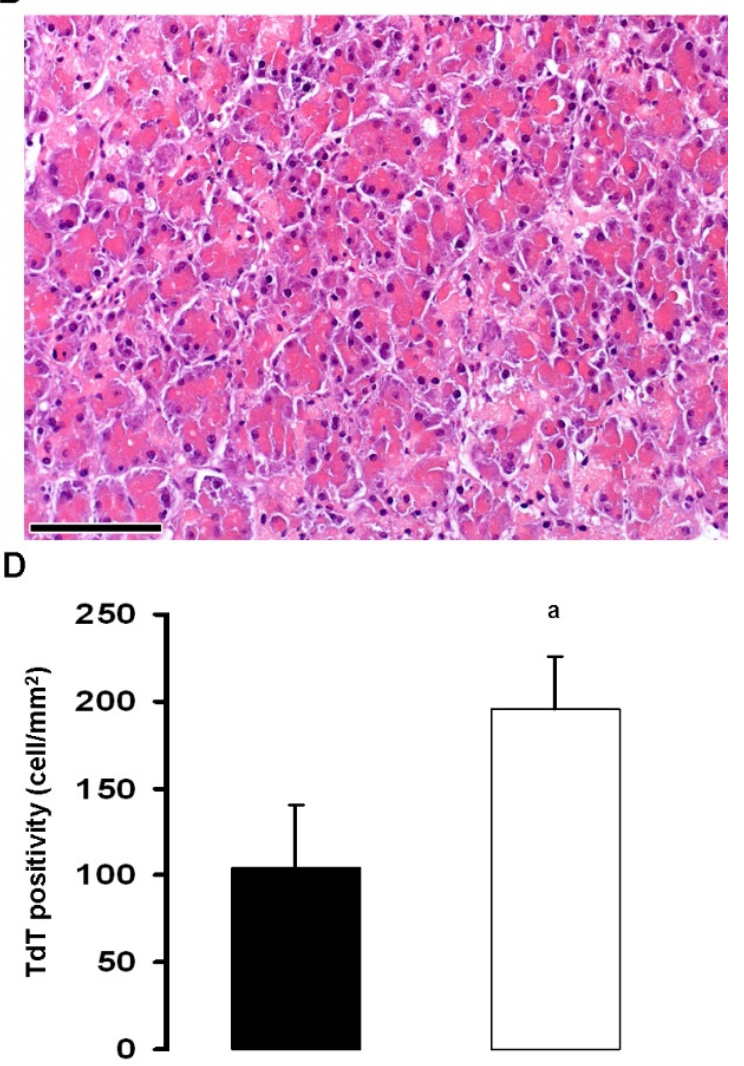

Figure 7. Histopathologic changes of the pancreas in response to i.p. administration of $7 \times 50 \mu \mathrm{g} / \mathrm{kg}$ cerulein in WT and NHERF-1-KO mice. Acute pancreatitis was induced in WT (closed columns) and NHERF-1-KO (open columns) mice by administering 7 hourly i.p. injections of cerulein (50 $\mu \mathrm{g} / \mathrm{kg}$ per injection). The mice were sacrificed by exsanguination through the inferior vena cava $12 \mathrm{~h}$ after the first i.p. injection. The diagrams show representative light micrographs (hematoxylin and eosin staining) of the pancreata of cerulein-treated WT (A) and NHERF-1-KO (B) mice. The bar diagrams show the rates of pancreatic necrosis $(\boldsymbol{C})$ and apoptosis $(\boldsymbol{D})$. Data are shown as means \pm SEM. a: $P<0.05$ vs. the WT group. Scale bar $=100 \mu \mathrm{m}$.

Of note, i.p. administration of $7 \times 50 \mu \mathrm{g} / \mathrm{kg}$ cerulein in WT and NHERF-1-KO mice caused similar effects in the investigated histological (Figure 7) and laboratory parameters (Figure 8), as shown for the higher cerulein dose. Overall, our results clearly demonstrate that the severity of cerulein-induced AP is lower in mice expressing NHERF-1. 
A

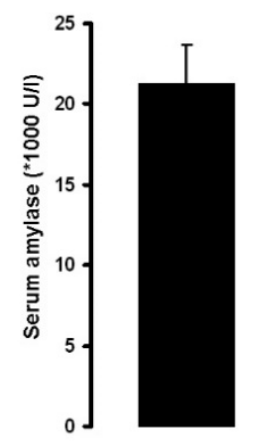

D

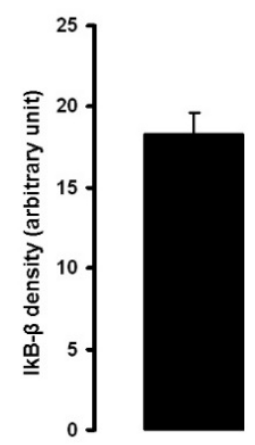

B

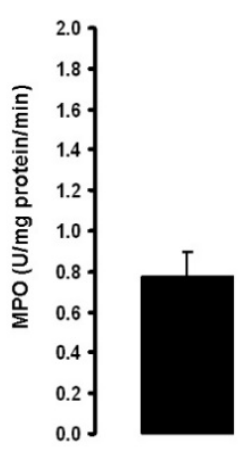

E

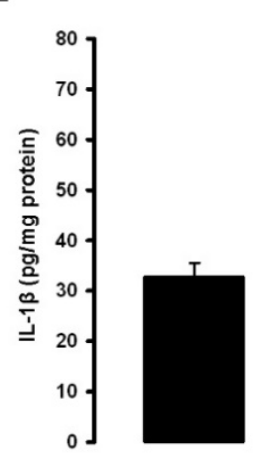

C
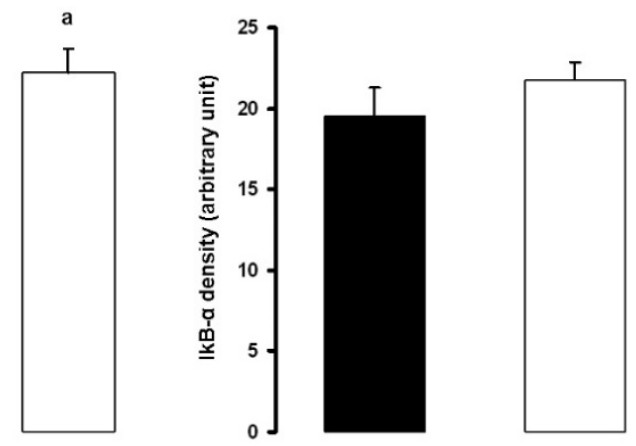

F

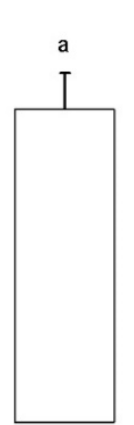

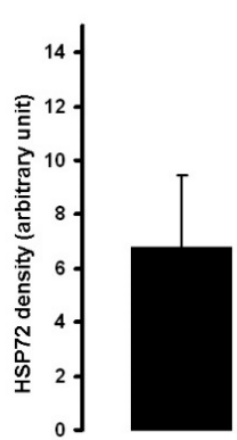

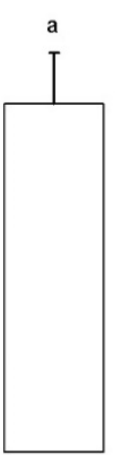

Figure 8. Severity of cerulein-induced $(7 x 50 \mu \mathrm{g} / \mathrm{kg})$ acute pancreatitis in WT and NHERF-1-KO mice. Acute pancreatitis was induced in WT (closed columns) and NHERF-1-KO (open columns) mice by administering 7 hourly i.p. injections of $50 \mu \mathrm{g} / \mathrm{kg}$ cerulein. The mice were sacrificed by exsanguination through the inferior vena cava $12 \mathrm{~h}$ after the first i.p. injection. There was no significant difference in serum amylase activity of WT and NHERF-1-KO mice (A). Pancreatic MPO activity was significantly increased in NHERF-1-KO vs. WT mice (B). No significant difference was detected between WT and NHERF-1-KO mice in expression of pancreatic I $B-\alpha(C)$. The expression of pancreatic I $\kappa B-\beta$ was significantly lower in NHERF-1-KO vs. WT mice (D). The expression of pancreatic IL-1 $\beta(\boldsymbol{E})$ and HSP72 $(\boldsymbol{F})$ were significantly higher in NHERF-1-KO vs. WT animals. Data are shown as means \pm SEM, $n=4-6$. a: $P<0.05$ vs. the respective control group.

To exclude any possible deleterious effects of NHERF-1 deletion on cholecystokinin receptor function, we tested the sensitivity of acinar cells to cerulein. Amylase secretion of acinar cells from WT and NHERF-1-KO animals showed no significant differences in response to cerulein stimulation (Figure 9.). 


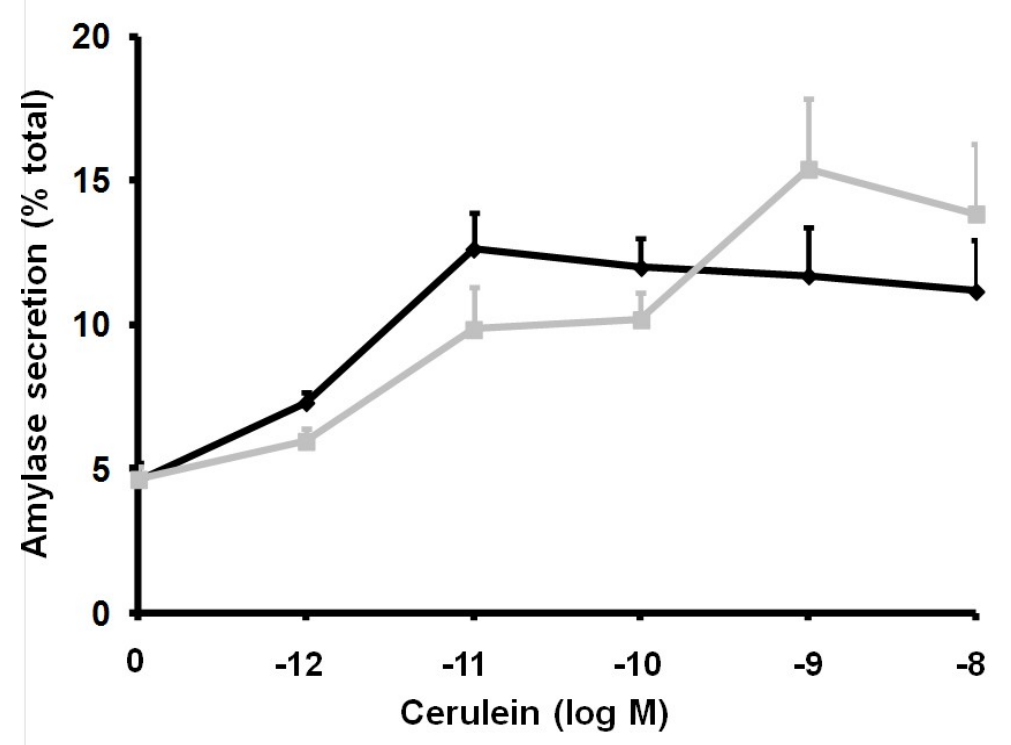

Figure 9. Pancreatic acinar sensitivity to cerulein is unaltered by NHERF-1 expression. To determine the sensitivity of dispersed acinar cells of WT (black line) and NHERF-1-KO (grey line) mice to cerulein, amylase secretion was determined in response to various concentrations $\left(10^{-12}-10^{-8} \mathrm{M}\right)$ of cerulein for $30 \mathrm{~min}$. Amylase secretion was calculated as the percent of total release (medium/medium + cells). a: $P<0.05$ vs. 0 M cerulein, $n=4-6$ animals.

\subsection{Intraductal administration of sodium-taurocholate causes more extensive acinar cell necrosis in NHERF-1-KO compared to wild-type mice}

We also investigated if $N H E R F-1-\mathrm{KO}$ mice respond differently than WT mice when AP was induced by i.d. infusion of $4 \%$ Na-taurocholate. Postoperative mortality after administration of Na-taurocholate in $\mathrm{KO}$ mice (2/14 animals) was not significantly different vs. WT animals (0/10). 
A

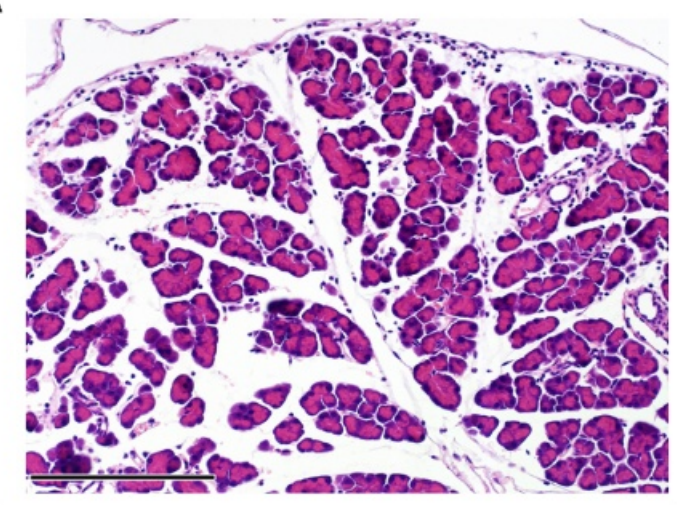

C

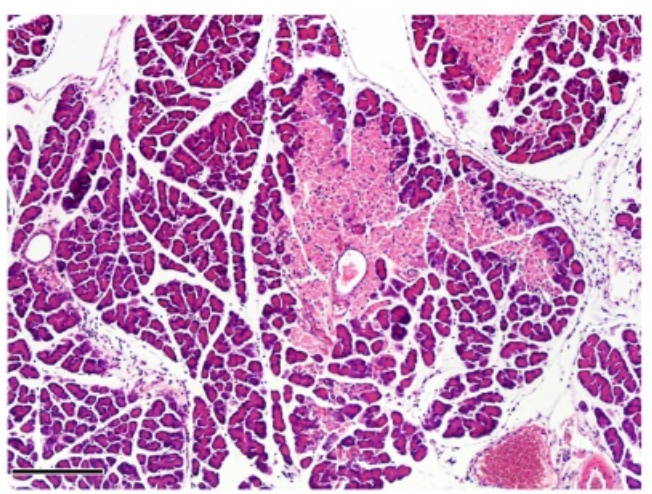

$\mathrm{E}$

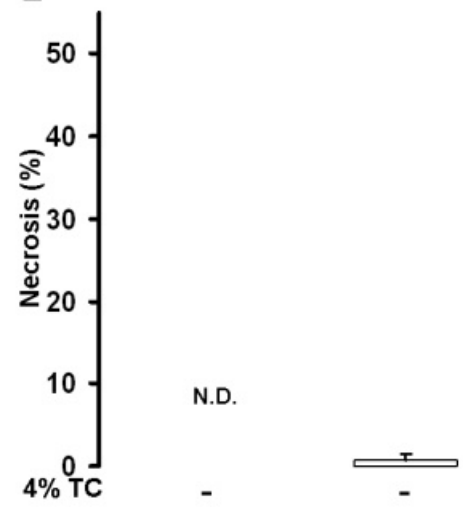

B

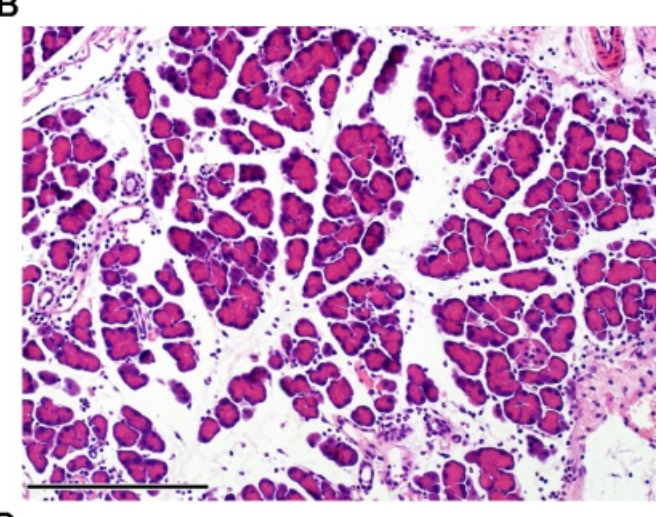

D
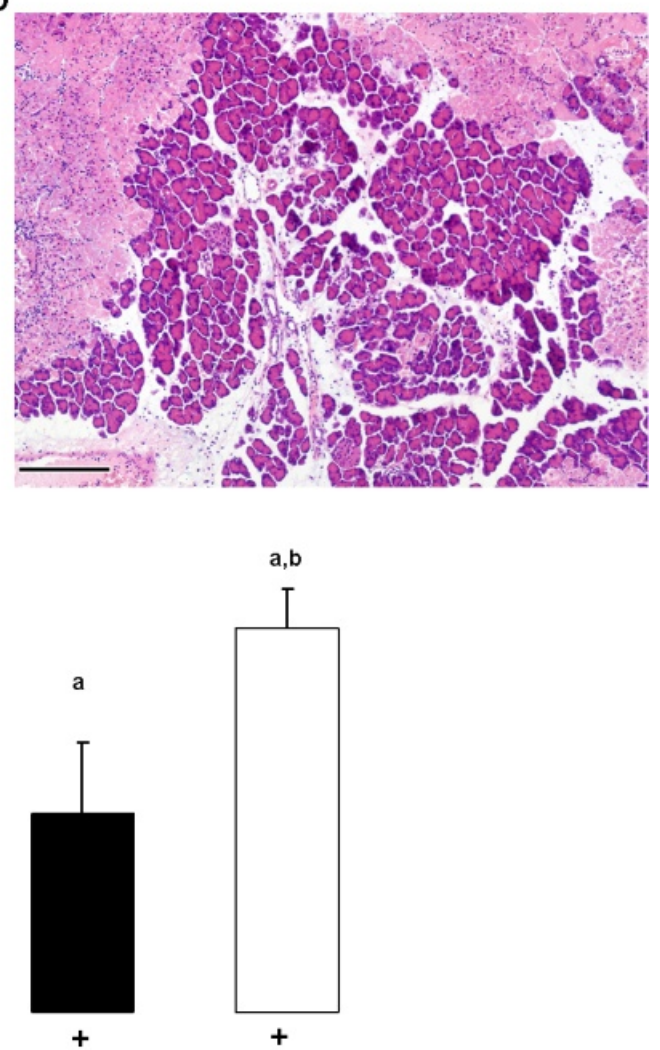

Figure 10. Histopathologic changes of the pancreatic head in response to intraductal (i.d.) administration of physiological saline (PS) and 4\% sodium-taurocholate in WT and NHERF-1-KO mice. The diagrams show representative light micrographs (H\&E staining) of pancreata of WT $(\boldsymbol{A}, \boldsymbol{C})$ and NHERF-1-KO (B, D) mice 24 h after intraductal treatment with $50 \mu \mathrm{l}(10 \mu \mathrm{l} / \mathrm{min})$ PS (4\%TC-) (A, B) or 4\% $\mathrm{Na}^{+}$-taurocholate $(4 \% \mathrm{TC}+)(\boldsymbol{C}, \boldsymbol{D})$. Inflammatory infiltration was significantly higher in NHERF-1-KO (A) vs. WT (B) PS-treated mice. Intraductal infusion with $4 \% \mathrm{Na}^{+}-$ taurocholate caused the development of severe acute necrotizing pancreatitis in WT (C) and NHERF-1-KO (D) mice. The bar diagram shows the rates of pancreatic necrosis $(\boldsymbol{E})$ in the various groups. Data are shown as means $\pm S E M, n=5-7$. $P<0.05$ vs. a: the respective control group or b: vs. the WT 4\%TC+ group. N.D.: not detected in the WT group. Scale bar $=200 \mu \mathrm{m}$. WT (closed columns), NHERF-1-KO (open columns).

I.d. infusion of PS caused no postoperative mortality, but mild pancreatic edema and inflammation were seen on histology without significant necrosis (Figure 10/A, B). 
The rate of leukocyte infiltration was significantly higher in the PS-treated NHERF-1-KO vs. WT mice (Table 1). The infusion of $4 \%$ Na-taurocholate into the pancreatic duct induced necrotizing AP in the head (Figure 10/C, D), but not in the tail of the pancreas (not shown). The latter finding is in accord with that of others [Perides et al. 2010]. Therefore; only the pancreatic heads were used for histological analysis. Approximately $24 \%$ of acinar cells were necrotic in WT (Figure 10/C, E) and about $47 \%$ in NHERF-1-KO mice (Figure 10/D, E). Table 1 summarizes the histopathological changes in the various groups. Significantly higher rates of leukocyte infiltration were detected in Na-taurocholate-treated vs. PS-treated WT groups. In contrast, there were no significant differences in leukocyte infiltration between the Na-taurocholate vs. PS-treated NHERF-1-KO groups, and Na-taurocholate-treated NHERF-1-KO vs. WT groups.

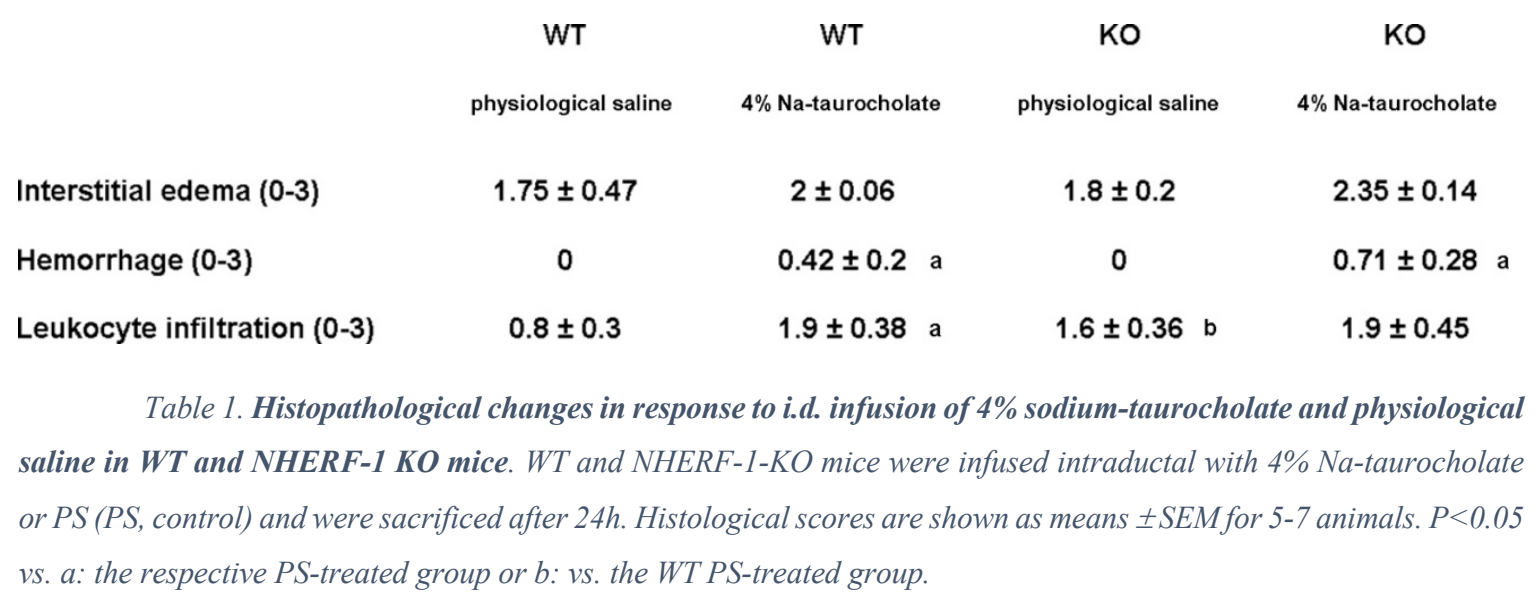

Serum amylase activities were significantly higher in Na-taurocholate-treated vs. control WT and NHERF-1-KO groups (Figure 11/A), but there were no differences between Na-taurocholate-treated NHERF-1-KO and WT mice. We did not observe any significant differences in pancreatic MPO activity between WT and NHERF-1-KO mice after i.d. PS infusion (Figure 11/B). However, MPO activity was increased in Na-taurocholate-treated NHERF-1-KO vs. control mice and even higher in the KO compared to the WT Na-taurocholate-treated mice. Pancreatic IL-1 $\beta$ expression was elevated in Na-taurocholate-treated WT and NHERF-1-KO mice vs. the control groups (Figure 11/C). However, there were no significant differences in the levels of IL-1 $\beta$ of Na-taurocholate-treated WT and NHERF-1-KO animals. 
A

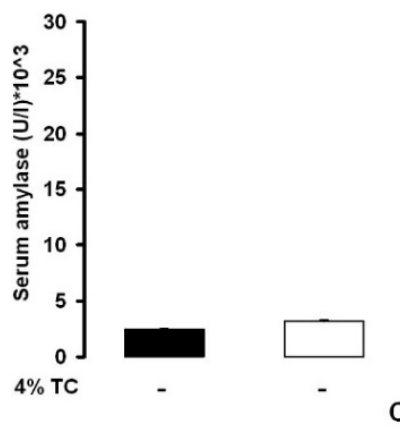

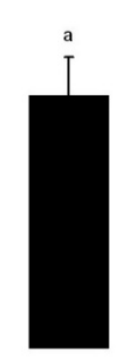

C

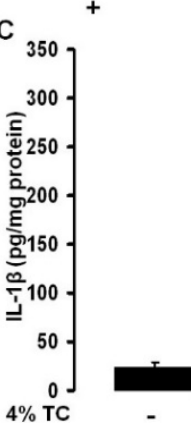

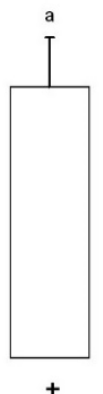

$+$
B
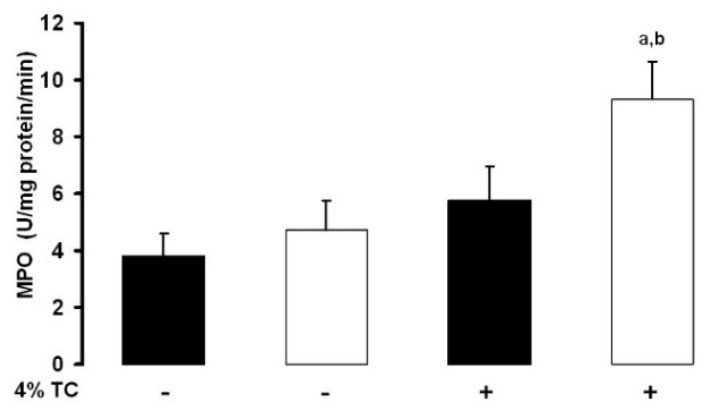

Figure 11. Severity of sodium-taurocholate-induced acute pancreatitis in WT and NHERF-1 KO mice. WT and NHERF-1-KO mice were treated as described earlier. The mice were sacrificed by exsanguination through the inferior vena cava $24 \mathrm{~h}$ after the infusion. There were no significant differences in serum amylase (A) and pancreatic MPO (B) activities between $\mathrm{Na}^{+}$-taurocholate-treated WT (closed columns) and NHERF-1-KO (open columns) mice. There was no significant difference in the levels of pancreatic $I L-1 \beta$ (C) of $N a^{+}$-taurocholate-treated $W T$ and NHERF-1-KO mice. Data are shown as means \pm SEM, $n=4-6$. $P<0.05$ vs. a: the respective control group or $b$ : vs. the WT $4 \%$ TC+ group.

These data indicate that NHERF-1 expression reduces Na-taurocholate-induced pancreatic injury, but it does not necessarily influence other laboratory parameters of the disease.

\subsection{The severity of acute pancreatitis is aggravated in aquaporin-1 KO mice}

In order to test the hypothesis that AQP1 may be involved in the pathomechanism of pancreatitis, we investigated the severity of cerulein-induced AP in WT and $A Q P 1 \mathrm{KO}$ mice. WT and AQP1 KO mice were given 10 hourly injections of either PS (control) or supramaximal doses of cerulein $(50 \mu \mathrm{g} / \mathrm{kg}$ per injection) i.p. After saline injection, the pancreas had normal histology in both WT and KO animals. In contrast, i.p. injections of cerulein caused extensive cell damage both in the WT and KO animals. The extent of 
pancreatic necrosis was markedly greater in the $A Q P 1 \mathrm{KO}(25 \pm 2.8 \%)$ vs. WT mice $(12.1 \pm 3.2 \%)$, whereas significant no differences were observed in the extent of edema and in the infiltration of inflammatory cells (Figure 12/A-C).
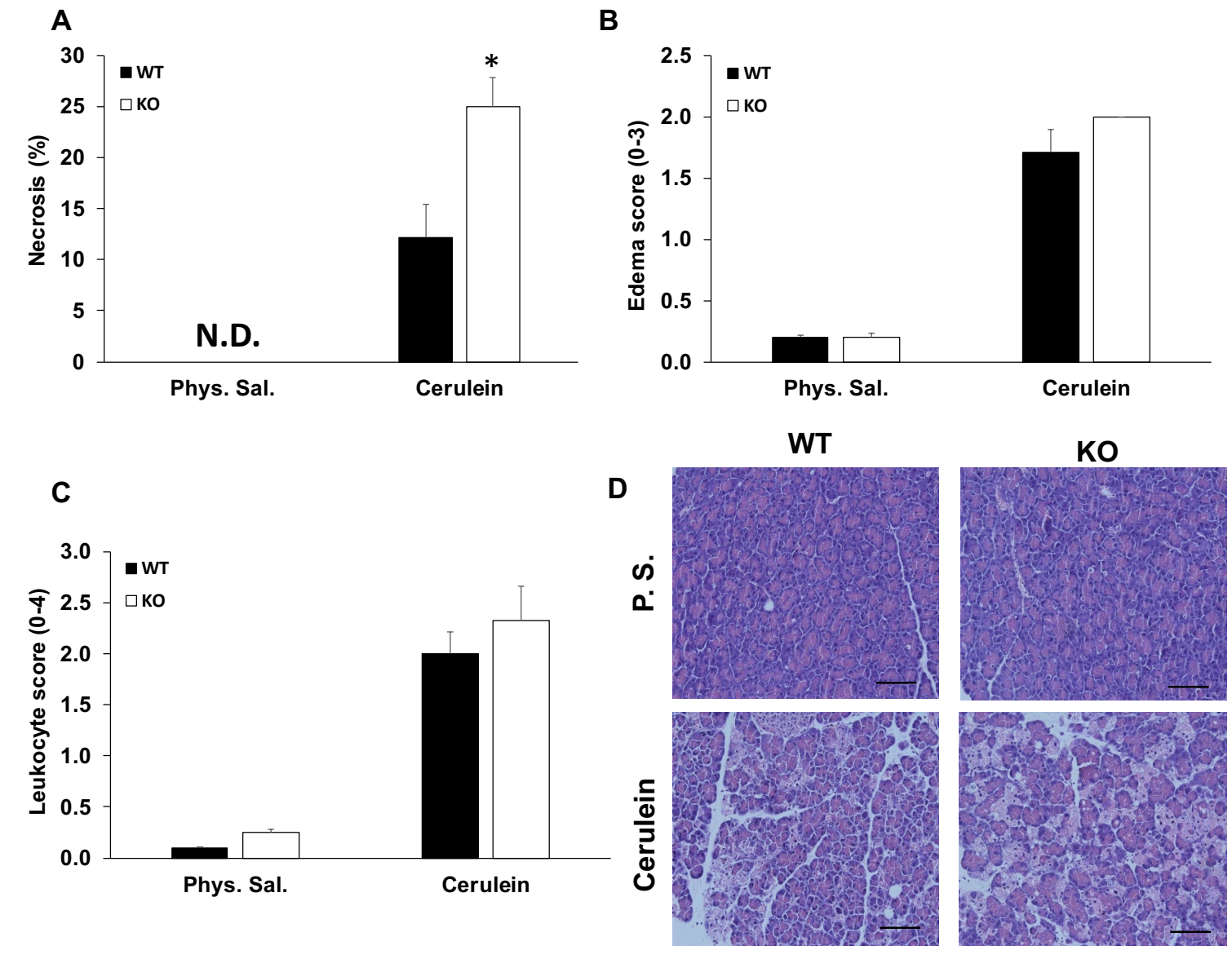

Figure 12. Histopathologic changes of cerulein-induced $(10 \times 50 \mu \mathrm{g} / \mathrm{kg})$ acute pancreatitis in WT and AQP1 KO mice. Pancreatic cell necrosis $(\boldsymbol{A})$, edema $(\boldsymbol{B})$, leukocyte infiltration $(\boldsymbol{C})$ were measured in WT and AQP1 KO mice after induction of pancreatitis. Control animals received the same amount of PS. Data are presented as means \pm SEM. *: $p \leq 0.05$ vs. WT. Representative histological images show pancreatic sections from control (physiological saline) and cerulein-treated animals (D). P.S.: physiological saline. N.D.: not detected; $n=6-8$. Scale bar=50 $\mu$ m.

As shown on the representative histological images (Figure 12/D), the rate of pancreatic necrosis was more extensive in $A Q P 1 \mathrm{KO}$ mice. Serum amylase activities were significantly higher in KO (1605 $\pm 6 \mathrm{U} / \mathrm{l})$ vs. WT mice $(1285 \pm 51 \mathrm{U} / \mathrm{l})$ after the induction of AP (Figure 13). Overall, these results indicate that in the absence of AQP1 expression, the course of pancreatitis is more severe. 


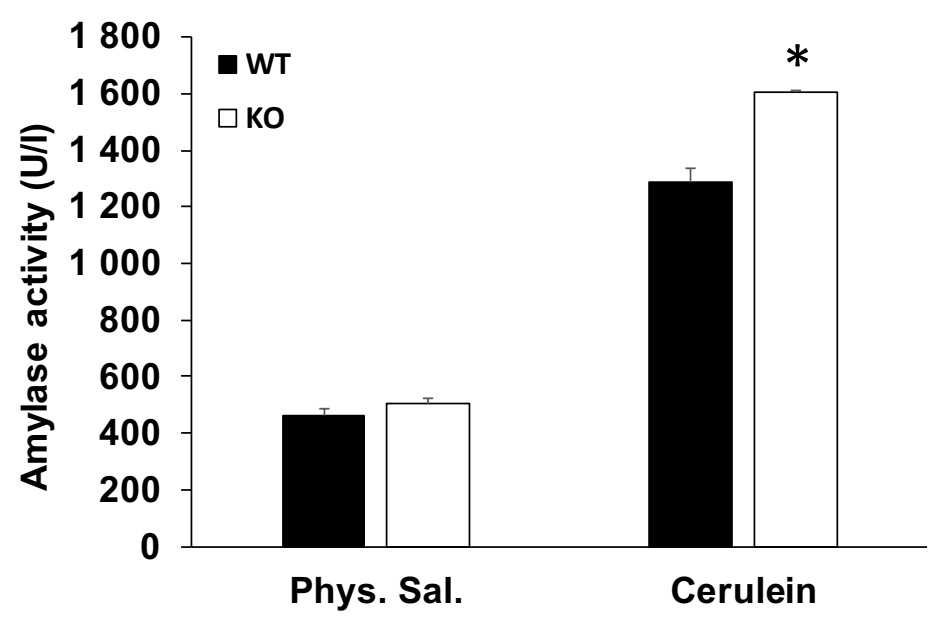

Figure 13. Serum amylase activity is increased in cerulein-induced $(10 \times 50 \mu \mathrm{g} / \mathrm{kg})$ acute pancreatitis in AQP1 KO vs. WT mice. Serum amylase activity (U/l) was measured in WT and AQP1 KO mice after induction of pancreatitis. Control animals received the same amount of PS. Data are presented as means \pm SEM. *: $p \leq 0.05$ vs. WT. Phys. Sal.: physiological saline. $n=6-8$. 


\section{Discussion}

Accumulating evidence suggests that pancreatic ducts have prominent roles not only physiologically but also pathophysiologically. It is well known that insufficient electrolyte and fluid secretion by ductal cells in CF lead to the destruction of acini [Steward et al. 2009]. On the other hand, numerous CFTR mutations predispose to chronic pancreatitis [Chen et al. 2009]. Until quite recently, the pathophysiological relevance of pancreatic ducts in AP has been neglected. It is commonly assumed that the primary target of all stressors is the acinar cells since they are damaged in all forms of AP. However, both clinical and experimental data suggest that pancreatic ductal cells may also have fundamental roles in the development of AP [Hegyi et al. ${ }^{2011]}$. Cavestro et al. ${ }^{[2010]}$ have found a statistically significant association of CFTR gene mutations in patients with recurrent AP. Pancreatic fluid secretion is greatly increased at the initiation of AP [Czako et al. 1997]. Also, in vitro administration of agents inducing AP such as ethanol, bile acids or viruses to pancreatic duct cells stimulate bicarbonate secretion [Hegyi et al. 2011, Venglovecz et al. 2008]. Our hypothesis is that ductal secretion serves to defend the pancreas by washing out toxic agents such as activated digestive enzymes when NHERF-1 protein is present. If this ductal defense mechanism is insufficient, ductal secretion will be inhibited, and the harmful enzymes cannot leave the pancreas, so it leads to more severe AP. The beneficial effect of ductal fluid hypersecretion is indicated by the fact that secretin, a major mediator of pancreatic ductal secretion, has been shown to protect against cerulein-induced AP [Niederau et al. 1985, Renner et al. 1983]. Furthermore, there is accumulating evidence that impaired pancreatic fluid secretion plays a role in the pathomechanism of pancreatitis [Hegyi et al. 2010, Maleth et al. 2015, Pallagi et al. 2014].

In the present study, we investigated the roles of NHERF-1 and AQP1 (both of which have essential roles in pancreatic ductal secretion) in experimental AP. 


\subsection{The role of NHERF-1 in acute experimental pancreatitis}

In the related article, we have demonstrated that NHERF-1 mRNA is highly expressed in mouse pancreatic ducts [Pallagi et al.2014. Furthermore, the genetic deletion of NHERF-1 greatly reduced the expression of CFTR in the luminal ductal cell membrane and also decreased both in vitro and in vivo pancreatic bicarbonate and fluid secretion. This may contribute to significantly increased severity of acute necrotizing pancreatitis in NHERF-1-KO mice in two distinct models. Importantly, early acinar events associated with $\mathrm{AP}$, like trypsinogen and $\mathrm{NF}-\kappa \mathrm{B}$ activation, were unaltered by genetic deletion of NHERF-1. However, late events such as apoptosis and necrosis were increased in the KO animals. Notably, the genetic deletion of $N H E R F-1$ had no deleterious effects on functions of acinar and inflammatory cells, indicating that increased severity of the disease is precisely due to impaired ductal secretion.

NHERF-1 has been identified as a CFTR-interacting PDZ domain protein, which is involved in the apical targeting of CFTR, signal complex formation with a variety of receptors, and possibly the interaction with other membrane transport proteins, in a cell and signal-specific manner [Benharouga et al. 2003, Milewski et al. 2001, Moyer et al. 1999, Ostedgaard et al. 2003, Raghuram et al. 2001, Swiatecka-Urban et al. 2002, Wu et al. 2012]. Consistent with our findings, mutations in CFTR that cause CF can also impair the stability of the $\mathrm{Cl}^{-}$channel in the plasma membrane and also result in markedly reduced bicarbonate and fluid secretion [Lukács et al. 2012]. Our study does not differentiate between a loss of $\mathrm{HCO}_{3}^{-}$and fluid secretion via CFTR or via a disruption between CFTR and other transporters involved in pancreatic bicarbonate and fluid secretion, such as solute carrier family 26 (SLC26) anion exchangers. Of note, both DRA and PAT-1 are known to have PDZ domain-binding motifs [Lamprecht et al. 2006] and bind to NHERF-1 [Lamprecht et al. 2002, Lohi et al. 2003, Rosmann et al. 2005]. In addition, activation of CFTR by SLC26 transporters was shown to be facilitated by PDZ ligands [Ko et al. 2004]. The reduced expression of CFTR in the apical membrane in NHERF-1-KO pancreatic ducts thus will likely decrease the activities of PAT-1 and DRA [Chernova et al. 2003, Rakonczay et al. 2008c].

Several groups have shown that the binding of CFTR to NHERF may regulate CFTR activity [Broere et al. 2007, Singh et al. 2009]. The unusually high expression of NHERF-1 and CFTR in pancreatic ducts is quite different from that found in the small intestine 
[Hillesheim et al. 2007, Singh et al. 2010]. These findings suggest to us that CFTR-NHERF-1 interaction may be crucial to pancreatic ductal secretion.

A striking finding of this study was that the severity of cerulein-induced acute necrotizing pancreatitis was significantly higher in animals lacking NHERF-1 (and thus reduced pancreatic ductal secretion), which suggests that normal ductal secretion in WT mice protects acinar cells against necrosis and apoptosis. This effect was independent of a change in cerulein sensitivity of acinar cells and shows that NHERF-1 expression is not necessary for cholecystokinin receptor function. Similar to our findings, another group has shown that transgenic mice with reduced CFTR expression were more susceptible to cerulein-induced AP [DiMagno etal.2005, 2010]. As CFTR-KO mice exhibited constitutive overexpression of pancreatic proinflammatory mediators, this is not that surprising. However, we did not find any differences in basal pancreatic proinflammatory between WT and NHERF-1-KO mice. Furthermore, in the studies by DiMagno et al. ${ }^{[2005,2010]}$, only the cerulein-induced AP model was tested, and the acinar- versus ductal-specific effects were not investigated. To confirm that the effect of diminished secretion on AP severity was not specific to the cerulein-induced model, we also determined disease severity in the clinically

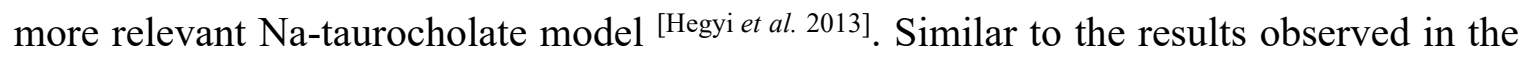
cerulein-induced pancreatitis model, the degree of acinar cell damage in Na-taurocholateinduced AP was significantly greater in NHERF-1-KO versus WT mice. Notably, the lower degree of necrosis was not necessarily accompanied by markedly reduced levels of inflammatory infiltration. Interestingly, leukocyte infiltration was higher in NHERF-1-KO versus WT mice injected i.d. with PS. Our data indicate that KO animals may even be more sensitive to increased ductal pressure.

Importantly, NHERF-1 expression did not influence the degree of the cell damage caused by high concentrations of cerulein or sodium taurocholate in isolated acini. These data indicate that the general deletion of NHERF-1 does not affect acinar damage caused by the latter agents. Therefore, it is likely that factors other than variations in the direct effects of cerulein or sodium taurocholate on acinar cells are responsible for the differences in AP severities of WT and NHERF-1-KO mice. 


\subsection{The role of aquaporin-1 channel in acute experimental pancreatitis}

There are two ways for water transport through epithelial cells. One is the paracellular way along the osmotic gradient generated by the ion transporters, and the other one is the transcellular pathway via AQPs. In the case of the pancreatic ducts, it is not clear which pathway is dominant. However, the pancreatic ductal epithelium is a moderately leaky epithelium that favors the paracellular movement of water [Novak et al. 1988].

AQP1 is a water channel that is extensively expressed in pancreatic acinar and ductal cells that are involved in fluid secretion. Altered expression or localization of AQPs is associated with different gastrointestinal disorders, such as gastritis or diarrhea; therefore, many studies have been conducted to identify the specific role of particular AQP isoforms. Although AQP1 plays an essential role in pancreatic physiology, its function under pathological conditions is not known. In order to determine the role of the AQP1 channel in AP, we used $A Q P 1 \mathrm{KO}$ mice. In the present study, we showed that the decreased expression of AQP1 in pancreatic ductal cells induces more severe pancreatitis in a cerulein-induced pancreatitis model.

No differences were observed in body weight and physical appearance of WT and KO mice, although the lifespan of $A Q P 1$ deficient mice was slightly lower. There are contradictious data partly in contrast with previous observations demonstrating that defect in AQP1 expression cause only a small but not significant decrease in the rate of stimulated pancreatic fluid secretion [Ma et al. 2001.]. Although this discrepancy can be explained by the different methods used for the measurement of pancreatic fluid, nevertheless, other studies have found that decreased expression or function of AQP1 dramatically reduces ductal fluid secretion [Gabbi et al. 2008, Ko et al. 2002]. The close relationship between AQPs and CFTR has been confirmed in rat epididymis, where CFTR potentiates AQP9-mediated water permeability [Cheung et al. 2003]. Moreover, a direct interaction between AQPs and CFTR has also been observed in Sertoli cells [Jesus et al. 2014a, 2014b].

The deletion of $A Q P 1$ itself does not damage the pancreas and does not cause pancreatitis in mice, which might be due to the compensating effect of AQP5; however, it 
induces a more severe disease progression. The involvement of AQP1 in the pathophysiology of pancreatitis has already been raised previously [Kitami et al. 2007]. Kitami et al. have found that AQP1 expression decreased both in the ductal and acinar cells in a cerulein-induced AP model, which indicates that reduced levels of AQP1 may contribute to exocrine insufficiency. The importance of AQP1 in the exocrine pancreas has also been confirmed by the fact that this water channel is abundantly expressed in the zymogen granules of acinar cells and plays an essential role in zymogen swelling and probably secretion [Cho et al. 2002]. AQP12 is also expressed in the zymogen granule of acinar cells, and a huge amount of this isoform is present in the rough endoplasmic reticulum [Ohta et al. 2009]. In the absence of AQP12, a high concentration of cholecystokinin octapeptide makes the pancreas more susceptible to pancreatitis, presumably by the aberrant exocytosis of zymogen granules in these mice [Ohta et al. 2009]. All of these previous observations indicate that AQP1 has essential roles in both ductal and acinar functions and makes the pancreas more sensitive for AP. 


\section{Summary}

Introduction: Pancreatic ductal epithelial cells (PDEC) secrete an alkaline $\mathrm{HCO}_{3}^{-}$-rich isotonic fluid. The secretion of $\mathrm{HCO}_{3}^{-}$across the apical membrane of PDEC is mediated by cystic fibrosis transmembrane conductance regulator $\mathrm{Cl}^{-}$channel (CFTR) and solute carrier family 26 (SLC26) anion exchangers. $\mathrm{Na}^{+} / \mathrm{H}^{+}$exchanger regulatory factor isoform-1 (NHERF-1) is a cytosolic adaptor protein, which binds CFTR on the apical membrane of epithelial cells. Aquaporins (AQPs) facilitate the transepithelial water flow involved in epithelial fluid secretion in numerous tissues. Acute pancreatitis (AP) is a serious disorder in which specific treatment is still not possible. Accumulating evidence indicate that decreased pancreatic ductal fluid secretion plays an essential role in AP.

The role of NHERF-1 in the pancreas has not yet been investigated despite the fact that CFTR, a key regulator of epithelial function, is controlled by this scaffolding protein Also the functions of AQPs in the pancreas are less characterized. Our aim was to characterize the function of NHERF-1 and AQP1 in AP.

Methods: We used 12-16-week old WT, NHERF-1 knock-out (KO) and AQP1 KO male mice. In the AP groups, mice were injected 7 or 10 times hourly, intraperitoneally (i.p.) with $50 \mu \mathrm{g} / \mathrm{kg}$ cerulein. In another AP model, $4 \% \mathrm{Na}$-taurocholate was administered i.d. via the punctured duodenum. Control animals were injected i.p. or i.d. with PS instead of cerulein or Na-taurocholate $(n=6-8)$. Animals were sacrificed at 12 hours in case of the cerulein model or 24 hours in the Na-taurocholate experiment. Laboratory [serum amylase- or, pancreatic myeloperoxidase (MPO) activity, pancreatic IL-1 $\beta$ concentrations] and histological parameters (pancreatic necrosis, edema, inflammatory cell infiltration) were measured to evaluate disease severity. Expression of HSP-72, IкB- $\alpha$, and IкB- $\beta$ contents were determined by Western-blot analysis.

Our results showed that the induction of AP was successful in both models and also in both strains. The injection of mice with cerulein or Na-taurocholate increased the measured laboratory and histological parameters vs. the control groups. The measured 
laboratory (serum amylase, HSP72) and histological parameters (necrosis, apoptosis) were significantly elevated in AP mice injected with cerulein vs. control mice. In accord with

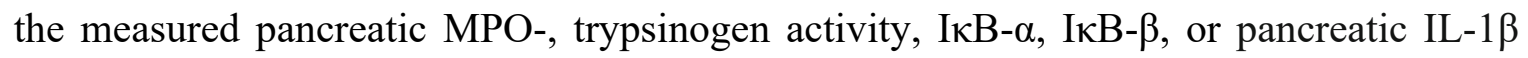
concentrations were not significantly altered in the NHERF-1 KO group vs. the WT AP groups. In case of the Na-taurocholate-induced AP, pancreatic necrosis, hemorrhage and MPO activity were significantly increased in the NHERF-1 KO group vs. the WT AP group. However, the pancreatic edema, leukocyte infiltration, IL-1 $\beta$ concentrations and serum amylase activity were significantly elevated in the WT or NHERF-1 KO AP vs. respective control groups but not in the NHERF-1 KO vs WT AP groups. The pancreatic leukocyte infiltration, edema, necrosis or serum amylase activity were significantly increased in cerulein-treated vs. control groups. In accord with the histological results, only necrosis and serum amylase activity were increased significantly in the AQP1 KO vs. WT AP groups.

In conclusion, after complete evaluation of the data, we can say that the AP in both NHERF-1 or AQP1 KO groups were more severe. These results may be due the reduced $\mathrm{HCO}_{3}^{-}$and fluid secretion. 


\section{Summary of new findings}

1. NHERF-1 and AQP1 have profound effects on the outcome of acute pancreatitis.

2. The severity of AP, particularly acinar necrosis and apoptosis was higher in NHERF-1 KO mice than in WT animals.

3. We have found that the deletion of $A Q P 1$ makes the pancreas more sensitive to pancreatitis. 


\section{Acknowledgements}

I would like to thank all the people who have helped and inspired me during my doctoral studies.

I would like to express my most sincere thanks to my mentor Prof. Dr. Zoltán Rakonczay, chairman of the Department of Pathophysiology, Faculty of Medicine, University of Szeged. Without his outstanding supervision, this $\mathrm{Ph} . \mathrm{D}$. thesis would not have been possible. I would like to also thank Prof. Dr. Péter Hegyi, chairman of the Institute for Translational Medicine, University of Pécs and Prof. Dr. Tamás Takács (First Department of Medicine, University of Szeged) for their guidance and support. Their wide knowledge and their logical way of thinking have been of great value for me. Their understanding and encouragement provided a good basis for this present thesis.

I am also grateful to Prof. Dr. Gyula Szabó, the former head of the Department of Pathophysiology Faculty of Medicine, University of Szeged, to Prof. Dr. Csaba Lengyel, Prof. Dr. György Ábrahám, and Prof. Dr. Tibor Wittmann, the current and former heads of the First Department of Medicine, and to Prof. Dr. András Varró, the former head of Department of Pharmacology and Pharmacotherapy, who provided me with the opportunity to work in their departments.

I would also like to thank my colleagues and friends, Dr. Balázs Kui, Dr. Eszter Kormányos, Dr. Máté Katona, Dr. István Németh, Dr. Eszter Hegyi, Dr. Anita Balázs, Dr. József Maléth, Dr. Klaudia Farkas, Dr. Mátyás Czepán, Dr. Balázs Németh, Dr. Petra Pallagi, Gabriella Für, Emese Réka Bálint, Tamara Madácsy, Dr. Éva Kunstár, Dr. Andrea Geisz, Dr. Andrea Schnúr, Dr. György Biczó, Nóra Gál, Emese Tóth, Júlia Fanczal, Andrea Molnár, Zsuzsanna Gyömbér, Árpád Varga, Réka Molnár, Dr. Dorottya Laczkó, Dr. Eszter Teréz Végh, Dr. Viktória Venglovecz, Dr. Eszter Becskeházi, Attila Ébert, Dr. Andrea Szentesi, Dr. Márta Gálfi, Dr. Marianna Radács, Dr. Miklós Jászberényi, Dr. Zsófia Mezei-Leprán, Dr. Zsolt Bagosi, Dr. Imre Pataki, Dr. Krisztina Csabafi, Dr. Júlia Szakács, Dr. Lóránd Kiss, Dr. Katalin Ibos, Dr. 
Árpád Gecse for all the help, encouragement and the great times we had, without them I would have been lost.

This thesis would not have been possible to accomplish without the assistance and help of Edit Magyarné Pálfi, Tünde Pritz, Rea Fritz, Miklósné Árva, Zoltánné Fuksz†, Dr. Mihály Zsilák-Urbán, Zoltán Kocsispéter, Zsolt Tóth, Magdolna Laurinyecz, Gusztáv Kiss, Ágnes Pál, Veronika Romhányi, Kitti Ancsányi, Erzsébet DallosSzilágyi, and Sándor Váczi.

I gratefully acknowledge the financial support that we received from the National Research, Development and Innovation Office (OTKA K116634, K119938, GINOP-2.3.215-2016-00015), the Ministry of Human Capacities (EFOP-3.6.2-16-2017-00006) and the MTA-SZTE Momentum Grant (LP2014-10/2014).

Last, but not least, I owe warm thanks to my parents and most importantly to my wife Márta Bába and also my kids Eszter and Áron for all their love, support, never-ending patience and encouragement. I dedicate this thesis to them.

"Per aspera ad astra" (Latin phrase) 


\section{References}

Argent BE, Gray MA, Steward MC, Case RM. Cell physiology of pancreatic ducts. In: Physiology of the gastrointestinal tract, Elsevier Inc, 2012; pp 1399-1424

Bedford JJ, Leader JP, Walker RJ. Aquaporin expression in normal human kidney and in renal disease. Journal of the American Society of Nephrology. 2003 Oct; 14:2581-2587.

Benharouga M, Sharma M, So J, Haardt M, Drzymala L, Popov M, Schwapach B, Grinstein $\mathrm{S}, \mathrm{Du} \mathrm{K}$, Lukacs GL. The role of the $\mathrm{C}$ terminus and $\mathrm{Na}+/ \mathrm{H}+$ exchanger regulatory factor in the functional expression of cystic fibrosis transmembrane conductance regulator in nonpolarized cells and epithelia. J Biol Chem. 2003; 278(24):22079-22089.

Bhatia M. Apoptosis versus necrosis in acute pancreatitis. Am J Physiol Gastrointest Liver Physiol 2004; 286:G189-96.

Bhoomagoud M, Jung T, Atladottir J, Kolodecik TR, Shugrue C, Chaudhuri A, Thrower EC, Gorelick FS. Reducing extracellular pH sensitizes the acinar cell to secretagogueinduced pancreatitis responses in rats. Gastroenterology 2009; 37:1083-1092.

Blaine J, Weinman EJ, Cunningham R. The regulation of renal phosphate transport. Adv Chronic Kidney Dis. 2011; 18:77-84.

Broere N, Hillesheim J, Tuo B, Jorna H, Houtsmuller AB, Shenolikar S, Weinman EJ, Donowitz M, Seidler U, de Jonge HR, Hogema BM. Cystic fibrosis transmembrane conductance regulator activation is reduced in the small intestine of $\mathrm{Na}+\mathrm{H}+$ exchanger 3 regulatory factor 1 (NHERF-1)- but not NHERF-2-deficient mice. J Biol Chem 2007; 282(52):37575-37584.

Brône B, Eggermont J. PDZ proteins retain and regulate membrane transporters in polarized epithelial cell membranes. Am J Physiol Cell Physiol. 2005; 288:C20-9

Burghardt B, Elkjaer ML, Kwon TH, Racz GZ, Varga G, Steward MC, Nielsen S. Distribution of aquaporin water channels AQP1 and AQP5 in the ductal system of the human pancreas. Gut 2003 Jul; 52:1008-1016. 
Cavestro GM, Zuppardo RA, Bertolini S, Sereni G, Frulloni L, Okolicsanyi S, Calzolari C, Singh SK, Sianesi M, Del Rio P, Leandro G, Franzè A, Di Mario F. Connections between genetics and clinical data: Role of MCP-1, CFTR, and SPINK-1 in the setting of acute, acute recurrent, and chronic pancreatitis. Am J Gastroenterol. 2010; 105(1):199-206.

Chen JM, Ferec C. Chronic pancreatitis: genetics and pathogenesis. Annu Rev Genomics Hum Genet 2009; 10:63-87.

Chernova MN, Jiang L, Shmukler BE, Schweinfest CW, Blanco P, Freedman SD, Stewart AK, Alper SL. Acute regulation of the SLC26A3 congenital chloride diarrhoea anion exchanger (DRA) expressed in Xenopus oocytes. J Physiol. 2003; 549(Pt 1):3-19.

Cheung KH, Leung CT, Leung GPH, Wong PYD. Synergistic effects of cystic fibrosis transmembrane conductance regulator and aquaporin- 9 in the rat epididymis. Biol Reprod. 2003 May; 68:1505-1510.

Cho SJ, Sattar A, Jeong EH, Satchi M, Cho JA, Dash S, Mayes MS, Stromer MH, Jena BP. Aquaporin 1 regulates GTP-induced rapid gating of water in secretory vesicles. Proc Natl Acad Sci USA. 2002 Apr; 99: 4720-4724.

Crawford I, Maloney PC, Zeitlin PL, Guggino WB, Hyde SC, Turley H, Gatter KC, Harris A, Higgins CF. Immunocytochemical localization of the cystic fibrosis gene product CFTR. Proc Natl Acad Sci USA. 1991; 88:9262-9266

Criddle DN, Gerasimenko JV, Baumgartner HK, Jaffar M, Voronina S, Sutton R, Petersen $\mathrm{OH}$, Gerasimenko OV. Calcium signalling and pancreatic cell death: apoptosis or necrosis? Cell Death Differ 2007; 14:1285-94.

Czako L, Yamamoto M, Otsuki M. Exocrine pancreatic function in rats after acute pancreatitis. Pancreas 1997; 15(1):83-90.

DiMagno MJ, Lee SH, Hao Y, Zhou SY, McKenna BJ, Owyang C. A proinflammatory, antiapoptotic phenotype underlies the susceptibility to acute pancreatitis in cystic fibrosis transmembrane regulator (-/-) mice. Gastroenterology 2005; 129(2):665-681.

DiMagno MJ, Lee SH, Owyang C, Zhou SY. Inhibition of acinar apoptosis occurs during acute pancreatitis in the human homologue DeltaF508 cystic fibrosis mouse. Am J Physiol Gastrointest Liver Physiol 2010; 299(2):G400-412. 
Dudeja V, Vickers SM, Saluja AK. The role of heat shock proteins in gastrointestinal diseases. Gut 2009; 58:1000-9.

Freedman SD, Kern HF, Scheele GA. Pancreatic acinar cell dysfunction in CFTR(-/-) mice is associated with impairments in luminal $\mathrm{pH}$ and endocytosis. Gastroenterology 2001; 121:950-7.

Furuya S, Naruse S, Ko SBH, Ishiguro H, Yoshikawa T, Hayakawa T. Distribution of aquaporin 1 in the rat pancreatic duct system examined with light- and electionmicroscopic immunohistochemistry. Cell and Tissue Research. 2002 Apr; 308:75-86.

Gabbi C, Kim HJ, Hultenby K, Bouton D, Toresson G, Warner M, Gustafsson JA. Pancreatic exocrine insufficiency in LXR beta(-/-) mice is associated with a reduction in aquaporin-1 expression. Proceedings of the National Academy of Sciences of the United States of America. 2008 Sep; 105:15052-15057.

Gorelick FS. Pancreas cell physiology and pancreatitis cell biology. Summary of a symposium held at the joint meeting of the EPC and the IAP, Heidelberg 2002. Pancreatology 2003; 3:207-8.

Gukovskaya AS, Gukovsky I, Zaninovic V, Song M, Sandoval D, Gukovsky S, Pandol SJ. Pancreatic acinar cells produce, release, and respond to tumor necrosis factor-alpha. Role in regulating cell death and pancreatitis. J Clin Invest 1997; 100:1853-62.

Halangk W, Lerch MM, Brandt-Nedelev B, Roth W, Ruthenbuerger M, Reinheckel T, Domschke W, Lippert H, Peters C, Deussing J. Role of cathepsin B in intracellular trypsinogen activation and the onset of acute pancreatitis. J Clin Invest 2000; 106:773-81.

Hegyi P, Rakonczay Z. Insufficiency of Electrolyte and Fluid Secretion by Pancreatic Ductal Cells Leads to Increased Patient Risk for Pancreatitis. Am J Gastroenterol. 2010 Sep; 105:2119-2120.

Hegyi P, Pandol S, Venglovecz V, Rakonczay Z Jr.: The acinar-ductal tango in the pathogenesis of acute pancreatitis. Gut 2011; 60(4):544-552.

Hegyi P, Perides G, Steer ML, Rakonczay Z Jr. Commonly employed rodent models of experimental acute pancreatitis: Their strengths and weaknesses, relevance to human 
disease, selection, and appropriate use. The Pancreapedia: Exocrine Pancreas Knowledge Base 2013; DOI: 10.3998/panc.2013.4.

Hegyi P, Wilschanski M, Muallem S, Lukacs GL, Sahin-Toth M, Uc A, Gray MA, Rakonczay Z Jr, Maleth J. CFTR: a new horizon in the pathomechanism and treatment of pancreatitis. Rev Physiol Biochem Pharmacol 2016; 170:37-66

Hillesheim J, Riederer B, Tuo B, Chen M, Manns M, Biber J, Yun C, Kocher O, Seidler U: Down regulation of small intestinal ion transport in PDZK1- (CAP70/NHERF3) deficient mice. Pflugers Arch 2007; 454(4):575-586.

Hofbauer B, Saluja AK, Lerch MM, Bhagat L, Bhatia M, Lee HS, Frossard JL, Adler G, Steer ML. Intra-acinar cell activation of trypsinogen during caerulein-induced pancreatitis in rats. Am J Physiol. 1998; 275:G352-62.

Hurley PT, Ferguson CJ, Kwon TH, Andersen MLE, Norman AG, Steward MC, Nielsen $\mathrm{S}$, Case RM. Expression and immunolocalization of aquaporin water channels in rat exocrine pancreas. Am J Physiol Gastrointest Liver Physiol. 2001 Apr; 280:G701-G709.

Ishiguro H, Namkung W, Yamamoto A, Wang Z, Worrell RT, Xu J, Lee MG, Soleimani M. Effect of Slc26a6 deletion on apical Cl-/HCO3- exchanger activity and cAMPstimulated bicarbonate secretion in pancreatic duct. Am J Physiol Gastrointest Liver Physiol. 2007 Jan; 292(1):G447-55. PMID: 16901991.

Itoh T, Rai T, Kuwahara M, Ko SBH, Uchida S, Sasaki S, Ishibashi K. Identification of a novel aquaporin, AQP12, expressed in pancreatic acinar cells. Biochemical and Biophysical Research Communications. 2005 May; 330:832-838.

Jesus TT, Bernardino RL, Martins AD, Sa R, Sousa M, Alves MG, Oliveira PF. Aquaporin4 as a molecular partner of cystic fibrosis transmembrane conductance regulator in rat Sertoli cells. Biochem Biophys Res Commun. 2014a. Apr; 446:1017-1021.

Jesus TT, Bernardino RL, Martins AD, Sa R, Sousa M, Alves MG, Oliveira PF. Aquaporin9 is Expressed in Rat Sertoli Cells and Interacts with the Cystic Fibrosis Transmembrane Conductance Regulator. Iubmb Life. 2014b Sep; 66:639-644. 
Kitami C-e, Koyama Y, Nishino H, Kurosaki I, Iiai T, Hatakeyama K. Dynamics of aquaporin 1 and aquaporin 8 in the pancreas: An experimental study with a caeruleininduced pancreatitis model. Acta Medica et Biologica. 2007; 55:91-101.

Ko SB, Zeng W, Dorwart MR, Luo X, Kim KH, Millen L, Goto H, Naruse S, Soyombo A, Thomas PJ, Muallem S. Gating of CFTR by the STAS domain of SLC26 transporters. Nat Cell Biol. 2004; 6:343-350.

Ko SB, Naruse S, Kitagawa M, Ishiguro H, Furuya S, Mizuno N, Wang YX, Yoshikawa T, Suzuki A, Shimano S, Hayakawa T. Aquaporins in rat pancreatic interlobular ducts. Am J Physiol Gastrointest Liver Physiol. 2002 Feb; 282:G324-G331.

Kopelman H, Durie P, Gaskin K, Weizman Z, Forstner G. Pancreatic fluid secretion and protein hyperconcentration in cystic fibrosis. N Engl J Med. 1985; 312:329-334.

Kuebler WM, Abels C, Schuerer L, Goetz AE. Measurement of neutrophil content in brain and lung tissue by a modified myeloperoxidase assay. Int J Microcirc Clin Exp. 1996; 16:89-97.

Kui B, Balla Z, Vasas B, Végh ET, Pallagi P, Kormányos ES, Venglovz V, Iványi B, Takács T, Hegyi P, Rakonczay Z Jr. New insights into the methodology of L-arginineinduced acute pancreatitis. PLoS One. 2015 Feb 17; 10(2):e0117588. doi: 10.1371/journal.pone.0117588. PubMed PMID: 25688985.

Kunkel MT, Garcia EL, Kajimoto T, Hall RA, NeVTon AC. The protein scaffold NHERF1 controls the amplitude and duration of localized protein kinase D activity. J Biol Chem. 2009; 284:24653-61.

Lamprecht G, Heil A, Baisch S, Lin-Wu E, Yun CC, Kalbacher H, Gregor M, Seidler U: The down regulated in adenoma (dra) gene product binds to the second PDZ domain of the NHE3 kinase A regulatory protein (E3KARP), potentially linking intestinal Cl/HCO3- exchange to Na+/H+ exchange. Biochemistry 2002; 41(41):12336-12342.

Lamprecht G, Seidler U. The emerging role of PDZ adapter proteins for regulation of intestinal ion transport. Am J Physiol Gastrointest Liver Physiol. 2006; 291(5):G766-777.

Lawrence T. The nuclear factor NF-kappaB pathway in inflammation. Cold Spring Harb Perspect Biol 2009; 1:a001651. 
Li M, Wang W, Soroka CJ, Mennone A, Harry K, Weinman EJ, Boyer JL. NHERF-1 binds to Mrp2 and regulates hepatic Mrp2 expression and function. J Biol Chem. 2010; 285:19299-307.

Liu-Chen LY. Agonist-induced regulation and trafficking of kappa opioid receptors. Life Sci. 2004; 75:511-36.

Lohi H, Lamprecht G, Markovich D, Heil A, Kujala M, Seidler U, Kere J. Isoforms of SLC26A6 mediate anion transport and have functional PDZ interaction domains. Am J Physiol Cell Physiol. 2003; 284(3):C769-779.

Lukács GL, Verkman AS. CFTR: folding, misfolding and correcting the DeltaF508 conformational defect. Trends Mol Med 2012; 18(2):81-91.

Ma TH, Yang BX, Gillespie A, Carlson EJ, Epstein CJ, Verkman AS. Severely impaired urinary concentrating ability in transgenic mice lacking aquaporin-1 water channels. $\mathrm{J}$ Biol Chem. 1998 Feb; 273:4296-4299.

Ma TH, Jayaraman S, Wang KS, Song YL, Yang BX, Li J, Bastidas JA, Verkman AS. Defective dietary fat processing in transgenic mice lacking aquaporin-1 water channels. Am J Physiol-Cell Physiol. 2001 Jan; 280:C126-C134.

Madeira A, Moura TF, Soveral G. Aquaglyceroporins: implications in adipose biology and obesity. Cell Mol Life Sci. 2015 Feb; 72:759-771.

Maleth J, Balazs A, Pallagi P, Balla Z, Kui B, Katona M, Judak L, Nemeth I, Kemeny LV, Rakonczay Z, Venglovecz V, Földesi I, Pető Z, Somorácz Á, Borka K, Perdomo D, Lukacs GL, Gray MA, Monterisi S, Zaccolo M, Sendler M, Mayerle J, Kühn JP, Lerch MM, Sahin-Tóth M, Hegyi P. Alcohol Disrupts Levels and Function of the Cystic Fibrosis Transmembrane Conductance Regulator to Promote Development of Pancreatitis. Gastroenterology. 2015 Feb; 148:427-U278.

Malorni W, Campesi I, Straface E, Vella S, Franconi F. Redox features of the cell: a gender perspective. Antioxid Redox Signal. 2007; 9:1779-1801.

Marino CR, Matovcik LM, Gorelick FS, Cohn JA. Localization of the cystic fibrosis transmembrane conductance regulator in pancreas. J Clin Invest. 1991; 88:712-716 
Milewski MI, Mickle JE, Forrest JK, Stafford DM, Moyer BD, Cheng J, Guggino WB, Stanton BA, Cutting GR. A PDZ-binding motif is essential but not sufficient to localize the C terminus of CFTR to the apical membrane. J Cell Sci. 2001; 114(Pt 4):719-726.

Moyer BD, Denton J, Karlson KH, Reynolds D, Wang S, Mickle JE, Milewski M, Cutting GR, Guggino WB, Li M, Stanton BA. A PDZ-interacting domain in CFTR is an apical membrane polarization signal. J Clin Invest. 1999; 104(10):1353-1361.

Niederau C, Ferrell LD, Grendell JH. Caerulein-induced acute necrotizing pancreatitis in mice: protective effects of proglumide, benzotript, and secretin. Gastroenterology 1985; 88(5 Pt 1):1192-1204.

Noble MD, Romac J, Vigna SR, Liddle RA. A pH-sensitive, neurogenic pathway mediates disease severity in a model of post-ERCP pancreatitis. Gut 2008; 57:1566-71.

Norman JG, Franz MG, Fink GS, Messina J, Fabri PJ, Gower WR, Carey LC. Decreased mortality of severe acute pancreatitis after proximal cytokine blockade. Ann Surg. 1995; 221:625-31.

Novak I, Greger R. Electrophysiological study of transport-systems in isolated perfused pancreatic ducts - properties of the basolateral membrane. Pflugers Archiv-Eur J Physiol. 1988 Jan; 411:58-68.

Novak I, Haanes KA, Wang J. Acid-base transport in pancreas-new challenges. Front Physiol. 2013; 4:380.

Ohta E, Itoh T, Nemoto T, Kumagai J, Ko SBH, Ishibashi K, Ohno M, Uchida K, Ohta A, Sohara E, Uchida S, Sasaki S, Rai T. Pancreas-specific aquaporin 12 null mice showed increased susceptibility to caerulein-induced acute pancreatitis. Am J Physiol-Cell Physiol. 2009 Dec; 297:C1368-C1378.

Ostedgaard LS, Randak C, Rokhlina T, Karp P, Vermeer D, Ashbourne Excoffon KJ, Welsh MJ. Effects of C-terminal deletions on cystic fibrosis transmembrane conductance regulator function in cystic fibrosis airway epithelia. Proc Natl Acad Sci USA. 2003; 100(4):1937-1942.

Pallagi P, Venglovecz V, Rakonczay Z Jr, Borka K, Korompay A, Ozsvari B, Judak L, Sahin-Toth M, Geisz A, Schnur A, Maleth J, Takacs T, Gray MA, Argent BE, Mayerle J, 
Lerch MM, Wittmann T, Hegyi P. Trypsin reduces pancreatic ductal bicarbonate secretion by inhibiting CFTR Cl(-) channels and luminal anion exchangers. Gastroenterology 2011; $141: 2228-2239$.

Pallagi P, Balla Z, Singh AK, Dosa S, Ivanyi B, Kukor Z, Toth A, Riederer B, Liu YJ, Engelhardt R, Jármay K, Szabó A, Janovszky A, Perides G, Venglovecz V, Maléth J, Wittmann T, Takács T, Gray MA, Gácser A, Hegyi P, Seidler U, Rakonczay Z Jr. The Role of Pancreatic Ductal Secretion in Protection Against Acute Pancreatitis in Mice. Crit Care Med. 2014 Mar; 42:E177-E188.

Pallagi P, Hegyi P, Rakonczay Z Jr. The Physiology and Pathophysiology of Pancreatic Ductal Secretion: The Background for Clinicians. Pancreas. 2015 Nov; 44(8):1211-33. Review. PubMed PMID:26465950.

Pandol SJ, Saluja AK, Imrie CW, Banks PA. Acute pancreatitis: bench to the bedside. Gastroenterology 2007; 132:1127-51.

Parniczky A, Kui B, Szentesi A, Balazs A, Szucs A, Mosztbacher D, Czimmer J, Sarlos P, Bajor J, Godi S, Vincze Á, Illés A, Szabó I, Pár G, Takács T, Czakó L, Szepes Z, Rakonczay Z, Izbéki F, Gervain J, Halász A, Novák J, Crai S, Hritz I, Góg C, Sümegi J, Golovics P, Varga M, Bod B, Hamvas J, Varga-Müller M, Papp Z, Sahin-Tóth M, Hegyi P; Hungarian Pancreatic Study Group. Prospective, Multicentre, Nationwide Clinical Data from 600 Cases of Acute Pancreatitis. Plos One. 2016 Oct; 11: e0165309.

Perides G, van Acker GJ, Laukkarinen JM, Steer ML. Experimental acute biliary pancreatitis induced by retrograde infusion of bile acids into the mouse pancreatic duct. Nat Protoc. 2010; 5(2):335-341.

Preston GM, Carroll TP, Guggino WB, Agre P. Appearance of water channels in xenopus oocytes expressing red-cell chip28 protein. Science. 1992 Apr; 256:385-387.

Prié D, Beck L, Friedlander G, Silve C. Sodium-phosphate cotransporters, nephrolithiasis and bone demineralization. Curr Opin Nephrol Hypertens. 2004; 13:675-81.

Raghuram V, Mak DO, Foskett JK. Regulation of cystic fibrosis transmembrane conductance regulator single-channel gating by bivalent PDZ-domain-mediated interaction. Proc Natl Acad Sci U S A. 2001; 98(3):1300-1305. 
Rakonczay Z, Takacs T, Boros I, Lonovics J. Heat shock proteins and the pancreas. J Cell Physiol. 2003; 195:383-391.

Rakonczay Z Jr, Hegyi P, Dósa S, Iványi B, Jármay K, Biczó G, Hracskó Z, Varga IS, Karg E, Kaszaki J, Varró A, Lonovics J, Boros I, Gukovsky I, Gukovskaya AS, Pandol SJ, Takács T.. A new severe acute necrotizing pancreatitis model induced by L-ornithine in rats. Crit Care Med. 2008a; 36:2117-2127

Rakonczay Z Jr, Hegyi P, Takács T, McCarroll J, Saluja AK. The role of NF-kappaB activation in the pathogenesis of acute pancreatitis. Gut 2008b; 57:259-267

Rakonczay Z, Jr., Hegyi P, Hasegawa M, Inoue M, You J, Iida A, Ignáth I, Alton EW, Griesenbach U, Ovari G, Vág J, Da Paula AC, Crawford RM, Varga G, Amaral MD, Mehta A, Lonovics J, Argent BE, Gray MA. CFTR gene transfer to human cystic fibrosis pancreatic duct cells using a Sendai virus vector. J Cell Physiol. 2008c; 214(2):442-455.

Rau B, Poch B, Gansauge F, Bauer A, Nussler AK, Nevalainen T, Schoenberg MH, Beger HG. Pathophysiologic role of oxygen free radicals in acute pancreatitis: initiating event or mediator of tissue damage? Ann Surg. 2000; 231:352-60.

Renner IG, Wisner JR Jr, Rinderknecht H. Protective effects of exogenous secretin on ceruletide-induced acute pancreatitis in the rat. J Clin Invest. 1983; 72(3):1081-1092.

Ribatti D, Ranieri G, Annese T, Nico B. Aquaporins in cancer. Biochimica Et Biophysica Acta-General Subjects. 2014 May; 1840:1550-1553.

Roberts SE, Akbari A, Thorne K, Atkinson M, Evans PA. The incidence of acute pancreatitis: impact of social deprivation, alcohol consumption, seasonal and demographic factors. Aliment Pharmacol Ther. 2013 Sep; 38(5):539-48.

Rodriguez A, Catalan V, Gomez-Ambrosi J, Fruhbeck G. Aquaglyceroporins serve as metabolic gateways in adiposity and insulin resistance control. Cell Cycle. 2011 May; 10:1548-1556.

Rossmann H, Jacob P, Baisch S, Hassoun R, Meier J, Natour D, Yahya K, Yun C, Biber J, Lackner KJ, Fiehn W, Gregor M, Seidler U, Lamprecht G. The CFTR associated protein CAP70 interacts with the apical $\mathrm{Cl}-/ \mathrm{HCO}_{3}^{-}$exchanger DRA in rabbit small intestinal mucosa. Biochemistry 2005; 44(11):4477-4487. 
Saluja A, Hashimoto S, Saluja M, Powers RE, Meldolesi J, Steer ML. Subcellular redistribution of lysosomal enzymes during caerulein-induced pancreatitis. Am J Physiol 1987; 253:G508-16.

Saluja AK, Donovan EA, Yamanaka K, Yamaguchi Y, Hofbauer B, Steer ML. Ceruleininduced in vitro activation of trypsinogen in rat pancreatic acini is mediated by cathepsin B. Gastroenterology 1997; 113:304-10.

Shenolikar S, Voltz JW, Minkoff CM, Wade JB, Weinman EJ. Targeted disruption of the mouse NHERF-1 gene promotes internalization of proximal tubule sodium-phosphate cotransporter type IIa and renal phosphate wasting. Proc Natl Acad Sci U S A. 2002 Aug 20; 99(17):11470-5. PubMed Central PMCID: PMC123280.

Singh AK, Riederer B, Krabbenhoft A, Rausch B, Bonhagen J, Lehmann U, de Jonge HR, Donowitz M, Yun C, Weinman EJ, Kocher O, Hogema BM, Seidler U. Differential roles of NHERF1, NHERF2, and PDZK1 in regulating CFTR-mediated intestinal anion secretion in mice. J Clin Invest. 2009; 119(3):540-550.

Singh AK, Riederer B, Chen M, Xiao F, Krabbenhoft A, Engelhardt R, Nylander O, Soleimani M, Seidler U. The switch of intestinal Slc26 exchangers from anion absorptive to $\mathrm{HCO}_{3}^{-}$secretory mode is dependent on CFTR anion channel function. Am J Physiol Cell Physiol. 2010; 298(5):C1057-1065.

Steinfeld S, Cogan E, King LS, Agre P, Kiss R, Delporte C. Abnormal distribution of aquaporin-5 water channel protein in salivary glands from Sjogren's syndrome patients. Lab Invest. 2001 Feb; 81:143-148.

Steward MC, Ishiguro H, Case RM. Mechanisms of bicarbonate secretion in the pancreatic duct. Annu Rev Physiol. 2005; 67:377-409.

Steward MC, Ishiguro H. Molecular and cellular regulation of pancreatic duct cell function. Curr Opin Gastroenterol. 2009; 25:447-53.

Swiatecka-Urban A, Duhaime M, Coutermarsh B, Karlson KH, Collawn J, Milewski M, Cutting GR, Guggino WB, Langford G, Stanton BA. PDZ domain interaction controls the endocytic recycling of the cystic fibrosis transmembrane conductance regulator. J Biol Chem. 2002; 277(42):40099-40105. 
Tani T, Koyama Y, Nihei K, Hatakeyama S, Ohshiro K, Yoshida Y, Yaoita E, Sakai Y, Hatakeyama K, Yamamoto T. Immunolocalization of aquaporin-8 in rat digestive organs and testis. Arch Histol Cytol. 2001 May; 64:159-168.

Tinel H, Cancela JM, Mogami H, Gerasimenko JV, Gerasimenko OV, Tepikin AV, Petersen $\mathrm{OH}$. Active mitochondria surrounding the pancreatic acinar granule region prevent spreading of inositol trisphosphate-evoked local cytosolic $\mathrm{Ca}(2+)$ signals. Embo J. 1999; 18:4999-5008.

Tsubota K, Hirai S, King LS, Agre P, Ishida N. Defective cellular trafficking of lacrimal gland aquaporin-5 in Sjogren's syndrome. Lancet. 2001; 357:688-689.

Venglovecz V, Rakonczay Z, Jr, Ózsvári B, Takács T, Lonovics J, Varró A, Gray MA, Argent BE, Hegyi P. Effects of bile acids on pancreatic ductal bicarbonate secretion in guinea pig. Gut. 2008; 57(8):1102-1112.

Vinciane Saint-Criq Michael A. Gray Role of CFTR in epithelial physiology Cell. Mol. Life Sci. 2017; 74:93-115.

Wheeler D, Sneddon WB, Wang B, Friedman PA, Romero G. NHERF-1 and the cytoskeleton regulate the traffic and membrane dynamics of $\mathrm{G}$ protein-coupled receptors. J Biol Chem. 2007; 282:25076-87.

Whitcomb DC. Genetic polymorphisms in alcoholic pancreatitis. Dig Dis 2005; 23:247-54.

Williams JA, Yule DI. Stimulus-secretion coupling in pancreatic acinar cells. In: Physiology of the gastrointestinal tract. Elsevier Inc. 2012; pp 1361-1398.

Wu Y, Wang S, Farooq SM, Castelvetere MP, Hou Y, Gao JL, Navarro JV, Oupicky D, Sun F, Li C. A chemokine receptor CXCR2 macromolecular complex regulates neutrophil functions in inflammatory diseases. J Biol Chem. 2012; 287(8):5744-5755.

Yamamoto A, Ishiguro H, Ko SB, Suzuki A, Wang Y, Hamada H, Mizuno N, Kitagawa M, Hayakawa T, Naruse S. Ethanol induces fluid hypersecretion from guinea-pig pancreatic duct cells. J Physiol. 2003; 551:917-26.

Zhu C, Chen Z, Jiang ZY. Expression, Distribution and Role of Aquaporin Water Channels in Human and Animal Stomach and Intestines. Int J Mol Sci. 2016 Sep; 17:18. 


\section{APPENDIX}

Articles closely related to the subject of the thesis 


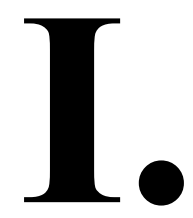




\section{The role of pancreatic ductal secretion in protection against acute pancreatitis in mice}

Petra Pallagi, $\mathrm{MSc}^{1 *}$; Zsolt Balla, MSc ${ }^{1 *}$; Anurag K. Singh, $\mathrm{PhD}^{2 *}$; Sándor Dósa, $\mathrm{MD}^{3}$; Béla Iványi, $\mathrm{MD}, \mathrm{PhD}, \mathrm{DSc}^{3}$; Zoltán Kukor, $\mathrm{MD}, \mathrm{PhD}^{4}$; Adél Tóth, $\mathrm{MSc}^{5}$; Brigitte Riederer, $\mathrm{PhD}^{2}$; Yongjian Liu, $\mathrm{MSc}^{2}$; Regina Engelhardt ${ }^{2}$; Katalin Jármay, $\mathrm{MD}, \mathrm{PhD}^{1}$; Andrea Szabó, $\mathrm{MD}, \mathrm{PhD}^{6}$; Ágnes Janovszky, $\mathrm{MD}^{6}$; George Perides, $\mathrm{PhD}^{7}$; Viktória Venglovecz, $\mathrm{PhD}^{8}$; József Maléth, $\mathrm{MD}^{1}$; Tibor Wittmann, $\mathrm{MD}, \mathrm{PhD}^{1}$; Tamás Takács, $\mathrm{MD}$, $\mathrm{PhD}, \mathrm{DSc}^{1}$; Mike A. Gray, $\mathrm{PhD}^{9}$; Attila Gácser, $\mathrm{PhD}^{5}$; Péter Hegyi, $\mathrm{MD}, \mathrm{PhD}, \mathrm{DSc}^{1}$; Ursula Seidler, $\mathrm{MD}, \mathrm{PhD}^{2}$; Zoltán Rakonczay Jr., MD, $\mathrm{PhD}, \mathrm{DSc}^{1}$

*The first three authors contributed equally.

University of Szeged, ${ }^{1}$ First Department of Medicine, ${ }^{3}$ Department of Pathology, ${ }^{5}$ Department of Microbiology, ${ }^{6}$ Institute of Surgical Research, ${ }^{8}$ Department of Pharmacology and Pharmacotherapy, Szeged, Hungary

${ }^{2}$ Department of Gastroenterology, Hepatology and Endocrinology, Hannover Medical School, Hannover, Germany

${ }^{4}$ Semmelweis University, Department of Medical Chemistry, Molecular Biology and Pathobiochemistry, Budapest, Hungary

${ }^{7}$ Department of Surgery, Tufts Medical Center, Boston, MA, USA

${ }^{9}$ Institute for Cell \& Molecular Biosciences, Newcastle University, Newcastle upon Tyne, UK

\section{Corresponding author, address reprint requests and proofs to:}

Dr. Zoltán Rakonczay, First Department of Medicine, University of Szeged

P.O. Box: 427, H-6701 Szeged, Hungary, Tel.: +36-62-545-200, Fax: +36-62-545185

E-mail: rakonczay.zoltan@med.u-szeged.hu 
Key words: NHERF-1; CFTR; pancreatic ducts; secretion; acute pancreatitis

Source of funding: This study was supported by National Development Agency grants (TÁMOP-4.2.2.A-11/1/KONV-2012-0035, TÁMOP-4.2.2-A-11/1/KONV-20120052 TÁMOP-4.2.2.A-11/1/KONV-2012-0073), the Hungarian Scientific Research Fund (NF105758 to Z.R., NF100677 to P.H., K101116 to T.T., and PD78087 to V.V.), the Hungarian Academy of Sciences (BO 00174/10/5 to Z.R., and DFG/192 to Z.R. and P.H.), the Deutsche Forschungsgemeinschaft (Se460/13-4, SFB621/C9 and the DeutschUngarisches Kooperationsprojekt DFG-436 UNG 113/190/01 to U.S.) and the National Institue of Health (DK 091327).

Abbreviations used in the paper: AP, acute pancreatitis; BCECF-AM, 2'7'bis(carboxyethyl)-5(6)-carboxyfluorescein acetoxymethyl ester; $\left[\mathrm{Ca}^{2+}\right]$, intracellular $\mathrm{Ca}^{2+}$ concentration; cAMP, cyclic AMP; CFTR, cystic fibrosis transmembrane conductance regulator $\mathrm{Cl}^{-}$channel; DAPI, 4',6-diamidino-2-phenylindole; DRA, down-regulated in adenoma; ELISA, enzyme-linked immunosorbent assay; FURA-2-AM, 5Oxazolecarboxylic acid, 2-(6-(bis(carboxymethyl)amino)-5-(2-(2(bis(carboxymethyl)amino)-5-methylphenoxy)ethoxy)-2-benzofuranyl)-5oxazolecarboxylic acetoxymethyl ester; $\mathrm{H}_{2}$ DIDS, dihydro-4,4'-diisothiocyanostilbene2,2'-disulfonic acid; HSP72, heat shock protein 72; IאB, inhibitor kappa B; IL-1 $\beta$, interleukin-1 $\beta$; $\mathrm{J}\left(\mathrm{B}^{-}\right)$, transmembrane base flux; KO, knock-out; LDH, lactate dehydrogenase; MPO, myeloperoxidase; NHE3, $\mathrm{Na}^{+} / \mathrm{H}^{+}$exchanger-3; NHERF-1, $\mathrm{Na}^{+} / \mathrm{H}^{+}$ exchanger regulatory factor-1; NF- $\kappa \mathrm{B}$, nuclear factor kappa B; PAT-1, Putative anion transporter 1; PBS, phosphate buffered saline; $\mathrm{pH}_{\mathrm{i}}$, intracellular $\mathrm{pH}$; PS, physiological saline; PDZ, postsynaptic density-95/disc-large/zonula occludens-1; SLC26, solute carrier family 26; TUNEL, terminal deoxynucleotidyl transferase dUTP nick end labeling; WT, wild type. 


\begin{abstract}
OBJECTIVE: A common potentially fatal disease of the pancreas is acute pancreatitis, for which there is no treatment. Most studies of this disorder focus on the damage to acinar cells since they are assumed to be the primary target of multiple stressors affecting the pancreas. However, increasing evidence suggest that the ducts may also have a crucial role in induction of the disease. To test this hypothesis, we sought to determine the specific role of the duct in the induction of acute pancreatitis using well established disease models and mice with deletion of the $\mathrm{Na}^{+} / \mathrm{H}^{+}$exchanger regulatory factor-1 (NHERF-1) that have selectively impaired ductal function.
\end{abstract}

DESIGN: Randomized animal study.

SETTING: Animal research laboratory.

SUBJECTS: Wild-type and NHERF-1 knock-out mice.

INTERVENTIONS: Acute necrotizing pancreatitis was induced by i.p. administration of cerulein or by intraductal administration of sodium-taurocholate. The pancreatic expression of NHERF-1 and cystic fibrosis transmembrane conductance regulator (CFTR, a key player in the control of ductal secretion) was analysed by immunohistochemistry. In vivo pancreatic ductal secretion was studied in anesthetized mice. Functions of pancreatic acinar and ductal cells, as well as inflammatory cells were analyzed in vitro.

MEASUREMENTS AND MAIN RESULTS: Deletion of NHERF-1 resulted in gross mislocalization of CFTR, causing marked reduction in pancreatic ductal fluid and bicarbonate secretion. Importantly, deletion of NHERF-1 had no deleterious effect on functions of acinar and inflammatory cells. Deletion of NHERF-1 that specifically impaired ductal function increased the severity of acute pancreatitis in the two models tested.

CONCLUSIONS: Our findings provide the first direct evidence for the crucial role of ductal secretion in protecting the pancreas from acute pancreatitis, and strongly suggest that improved ductal function should be an important modality in prevention and treatment of the disease. 


\section{INTRODUCTION}

A major disease of the exocrine pancreas is acute pancreatitis (AP) that is caused by multiple stressors and for which there is no specific treatment. The disorder usually develops either as a result of gallstone disease or moderate to heavy ethanol consumption [1]. It can present as mild edematous $(85 \%)$ or as severe necrotizing $(15 \%)$ forms, the latter of which can lead to a very high mortality rate of up to $50 \%$ in the case of multi-organ failure [1]. Most studies of AP focus on the function and damage to acinar cells since they are assumed to be the key target of stressors. However, increasing evidence point to the duct as the primary target of the stressors, which may have crucial role in induction of the disease.

The main function of the pancreatic duct is fluid and $\mathrm{HCO}_{3}{ }^{-}$secretion that is mediated by basolateral $\mathrm{HCO}_{3}{ }^{-}$influx due to $\mathrm{Na}^{+}-\mathrm{HCO}_{3}{ }^{-}$contransport by $\mathrm{NBCe} 1-\mathrm{B}$ and luminal $\mathrm{HCO}_{3}{ }^{-}$exit mediated by the concerted action of cystic fibrosis transmembrane conductance regulator (CFTR), DRA (down-regulated in adenoma or slc26a3) and PAT-1 (putative anion transporter 1 or slc26a6) [2]. The interrelated function of CFTR and PAT1 requires their assembly into complexes through postsynaptic density-95/disc-large/zonula occludens (PDZ) domains by an unknown scaffolding protein [3].

$\mathrm{Na}^{+} / \mathrm{H}^{+}$exchanger regulatory factor-1 (NHERF-1) is a scaffolding protein involved in the apical targeting and trafficking of several membrane proteins and anchors them to the cytoskeleton via ezrin [4]. NHERF-1 also facilitates the association of multiprotein complexes via PDZ and ezrin-radixin-moesin binding domains, a process that is essential for the adequate function of transporters, channels, and signaling complexes [5]. The adapter protein has been shown to bind to the PDZ-binding motifs of CFTR, $\mathrm{Na}^{+} / \mathrm{H}^{+}$ exchanger-3 (NHE3), as well as a number of other proteins that functionally interact with CFTR or NHE3, such as the $\beta_{2}$-adrenoreceptor $[6,7]$, or the Slc26 anion exchanger DRA [8].

The role of NHERF-1 in the pancreas has not yet been investigated, despite the fact that CFTR, a key regulator of epithelial function, is controlled by this scaffolding protein [4]. CFTR has very important roles in pancreatic ductal physiology [9] and in the pathogenesis of diseases like cystic fibrosis [5] and AP [10,11]. We reasoned that the 
central role of NHERF-1 in CFTR function offered a unique opportunity to directly evaluate, for the first time, the role of pancreatic ducts in AP by analyzing ductal function in mice with deletion of NHERF-1 and their response to induction of AP. 


\section{MATERIALS AND METHODS}

Brief outline of the methods is given below. For further details, please see the supplemental material.

\section{Ethics}

All experiments were conducted in compliance with the Guide for the Care and Use of Laboratory Animals (National Academies Press, Eight Edition, 2011), and were approved by Committees on investigations involving animals at the University of Szeged and at the Hannover Medical School and also by independent committees assembled by local authorities.

\section{Animals}

NHERF-1-deficient mice were originally generated and described at Duke University Medical Center [12]. NHERF-1 mutation was congenic for the FVB/N background for at least 15 generations. Genotyping was performed by PCR.

\section{Isolation and culture of pancreatic ducts and acini}

Intra-/interlobular pancreatic ducts were isolated and cultured overnight at $37^{\circ} \mathrm{C}$ in a humidified atmosphere containing $5 \% \mathrm{CO}_{2}$ as described previously [13]. Acinar cells were isolated by collagenase digestion and were used for experiments immediately thereafter [14]. 
Pancreatic ducts were homogenized by sonication in lysis-buffer and RNA was isolated with a NucleoSpin RNA XS Total RNA Isolation Kit. Reverse transcription was performed using Superscript III RT. The primer sequences and PCR protocol used for the determination of the mRNA expression of transporters and NHERF-1-3 are described in the supplementary methods.

\section{Localization of NHERF-1 and CFTR proteins by immunohistochemistry \\ Immunohistochemistry of the mouse pancreas was performed as described by Cinar et al [15] using rabbit polyclonal antibodies against NHERF-1 and CFTR.}

\section{Microperfusion and measurement of intracellular $\mathrm{pH}, \mathrm{Ca}^{2+}$}

\section{concentration}

The luminal and basolateral perfusions of the cultured ducts were performed as described previously [16]. Intracellular $\mathrm{pH}\left(\mathrm{pH}_{\mathrm{i}}\right)$ and $\mathrm{Ca}^{2+}$ concentration $\left(\left[\mathrm{Ca}^{2+}\right]_{\mathrm{i}}\right)$ were assessed using the fluorescent dye BCECF-AM[17] and FURA 2-AM, respectively.

\section{Determination of $\mathrm{HCO}_{3}^{-}$efflux}

To determine the $\mathrm{HCO}_{3}{ }^{-}$efflux across the apical membrane of the pancreatic ductal epithelia, we used three methods: inhibitory stop, alkali load and luminal $\mathrm{Cl}^{-}$withdrawal. The measured rates of $\mathrm{pH}_{\mathrm{i}}$ change $(\mathrm{dpH} / \mathrm{dt})$ were converted to transmembrane base flux $\left[\mathrm{J}\left(\mathrm{B}^{-}\right)\right]$which reflects the rate of $\mathrm{HCO}_{3}{ }^{-}$efflux (i.e. secretion) on luminal $\mathrm{Cl}^{-} / \mathrm{HCO}_{3}{ }^{-}$ exchangers [18].

\section{Measurement of fluid secretion}


Fluid secretion into the closed luminal space of in vitro cultured pancreatic ducts was analysed using a swelling method [19]. Basal and secretin-stimulated pancreatic fluid secretion in vivo was determined in anesthetized mice.

\section{Induction of acute pancreatitis}

\section{Cerulein-induced pancreatitis}

Mice were administered 1, 7 or 10 hourly i.p. injections of cerulein $(50 \mu \mathrm{g} / \mathrm{kg}$ per injection). Control mice were given physiological saline (PS: $0.9 \% \mathrm{NaCl}$ ) solution i.p. instead of cerulein.

\section{Sodium-taurocholate-induced pancreatitis}

Na-taurocholate was administered intraductally as described previously by Perides et al [20].

\section{Assays}

Amylase and lactate dehydrogenase (LDH) activities were measured with commercial kits. Acinar cell viability was determined using the trypan-blue exclusion test. Interleukin-1 $\beta$ (IL-1 $\beta$ ) levels were measured by ELISA. Expression of heat shock protein72

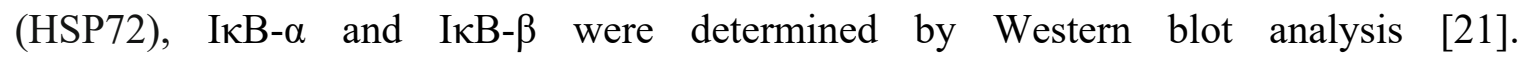
Myeloperoxidase (MPO) activity, as a marker of tissue leukocyte infiltration, was assessed by the method of Kuebler et al [22].

\section{Histologic examination}

Pancreatic injury was evaluated by semiquantitative grading of interstitial edema, haemorrhage and leukocyte infiltration [21]. The extent (\%) of cell damage was confirmed 
by analysis with ImageJ software (NIH, Bethesda, MD, USA). Apoptotic cells were quantified in $1 \mathrm{~mm}^{2}$ of pancreatic tissue by TUNEL assay using an In Situ Cell Death Detection Kit according to the manufacturer's instructions.

\section{Statistical analysis}

Statistical analysis was performed by SigmaPlot (Systat Software Inc., Chicago, IL, USA). Data are presented as means \pm SEM. Both parametric (one- or two-way analysis of variance) and non-parametric (Kruskal-Wallis) tests were used based on the normality of data distribution (analyzed by the Shapiro-Wilk test). Post-hoc analysis (either Dunn's or Bonferroni's test) was performed according to the recommendations made by SigmaPlot. $\chi^{2}$-test was used to determine differences between groups in the proportion of mice who died. A $\mathrm{P}<0.05$ was accepted as statistically significant. 


\section{RESULTS}

mRNA expression of CFTR, DRA, PAT-1 and NHERFs in mouse pancreatic ducts

CFTR, DRA, PAT-1, NHERF-1 and NHERF-2, but not NHERF-3 mRNA were expressed in isolated pancreatic ducts of WT mice (Fig.1). Notably, quantitative RT-PCR indicated that NHERF-1 was expressed more abundantly than the other two CFTR-binding NHERFs (NHERF-2 and NHERF-3).

\section{Apical NHERF-1 and CFTR localization in pancreatic ducts is reduced in NHERF-1-knock-out mice}

NHERF-1 was highly expressed in the apical membrane of pancreatic duct cells, but only weakly expressed in some acinar cells of WT mice (Fig.2A,B). No or weak staining was detected in NHERF-1-KO mice (Fig.2G,H). The weak staining is non-specific and was not localized to the luminal membrane.

Next, we determined whether NHERF-1 affects the localization of CFTR which was expressed in both pancreatic acinar and ductal cells. Compared to WT animals (Fig.2C), apical CFTR staining in pancreatic ducts was markedly reduced and overall CFTR staining in the pancreas appeared more diffuse in the absence of NHERF-1 (Fig.2I). Suppl.Fig. 1 shows that although the CFTR antibody gave a small amount of nonspecific staining, this was not localized to the luminal membrane. The strong cytoplasmic staining by the CFTR antibody correlates with the high CFTR mRNA expression levels in murine pancreas as compared to other gastrointestinal tissues (i.e. some cytoplasmic and basolateral staining in the duodenum [7], but not the ileum or colon of this mouse strain unpublished observations). Expression of pancreatic ductal CFTR mRNA was not significantly different in WT and NHERF-1-KO mice (results not shown).

Pancreatic ductal $\mathrm{HCO}_{3}{ }^{-}$secretion is decreased in NHERF-1-knock-out mice 
To determine if mislocalization of CFTR affects pancreatic ductal function, we investigated $\mathrm{HCO}_{3}{ }^{-}$secretion in isolated ducts using three different, but complementary methods that measure the rate at which $\mathrm{HCO}_{3}{ }^{-}$is secreted across the luminal membrane via $\mathrm{Cl}^{-} / \mathrm{HCO}_{3}{ }^{-}$exchangers and/or CFTR [18].

(1) Inhibitor stop. The administration of dihydro-4,4'-diisothiocyanostilbene-2,2'disulfonic acid $\left(\mathrm{H}_{2} \mathrm{DIDS}, 0.2 \mathrm{mM}\right)$ and amiloride $(0.2 \mathrm{mM})$ resulted in a rate of $\mathrm{J}\left(\mathrm{B}^{-}\right)$which was more than 4-fold lower in NHERF-1-KO compared to WT mice (Figs.3A,D).

(2) Alkali load. Here the recovery of $\mathrm{pH}_{\mathrm{i}}$ from an alkali load induced by exposure to $20 \mathrm{mM} \mathrm{NH}_{4} \mathrm{Cl}$ in a $\mathrm{HCO}_{3}{ }^{-} / \mathrm{CO}_{2}$-containing solution reflects the rate of $\mathrm{HCO}_{3}{ }^{-}$secretion [16]. Figs.3B and 3E show that the recovery from alkali load was about 2-fold lower in NHERF-1-KO vs. WT animals.

(3) Chloride removal. Figs.3C and $3 \mathrm{~F}$ show that $\mathrm{pH}_{\mathrm{i}}$ alkalinisation induced by removal of luminal $\mathrm{Cl}^{-}$was significantly reduced in NHERF-1-KO compared to WT mice.

These data show that pancreatic ductal $\mathrm{HCO}_{3}{ }^{-}$secretion was significantly reduced in NHERF-1-KO compared to WT mice.

\section{Fluid secretion is decreased in NHERF-1-knock-out mice}

To investigate if fluid secretion was also compromised in $\mathrm{KO}$ mice, the rate of fluid secretion was measured using sealed ducts. In the absence of secretagogue, we could not detect any significant changes in the volume of WT and NHERF-1-KO ducts (Fig.4A). Stimulation of WT ducts with $5 \mu \mathrm{M}$ forskolin caused dynamic swelling of the ducts as a result of fluid secretion into the closed luminal space. In contrast, ducts from NHERF-1KO mice had a blunted response to forskolin (Fig.4B).

We also examined the rate of pancreatic juice secretion in vivo in anesthetized mice. Under basal conditions, WT animals secreted pancreatic juice at a rate of $0.12 \pm 0.02 \mu \mathrm{l} / \mathrm{h} / \mathrm{g}$ body weight (Fig.4C). In contrast, we could not detect any basal secretion in NHERF-1$\mathrm{KO}$ animals. In response to secretin stimulation, we observed about 4-fold higher rates of pancreatic juice secretion in WT vs. NHERF-1-KO mice. These results demonstrate that 
pancreatic fluid secretion was significantly reduced in NHERF-1-KO compared to WT animals under both basal and secretin-stimulated conditions.

To rule out secondary alterations in pancreatic fluid secretion by changes in microcirculation due to loss of NHERF-1, we measured baseline microcirculatory plasma velocities in the capillaries of the pancreas, which were similar in WT and NHERF-1-KO animals (Suppl.Fig.2).

\section{Cerulein-induced pancreatitis is more severe in NHERF-1-knock-out mice}

To determine if the observed changes in pancreatic secretion could influence the development of AP, mice were given 10 hourly i.p. injections of either PS (control) or supramaximal doses of cerulein to induce AP (Fig.5A). The control animals had normal pancreatic histology (Fig.5A.a,d). I.p. injections of cerulein caused extensive cell damage (Fig.5A.b,c,e,f), the rates of necrosis (Fig.5B) and apoptosis (Fig.5C) were markedly higher in the NHERF-1-KO vs. WT mice. However, no significant differences were observed in the extent of interstitial edema ( $2.0 \pm 0.11$ for WT vs. $2.2 \pm 0.2$ for KO) or leukocyte infiltration $(1.72 \pm 0.08$ for WT vs. $1.95 \pm 0.13$ for $\mathrm{KO}, \mathrm{p}=0.08)$ in cerulein-treated groups.

There were also no significant differences between WT and NHERF-1-KO control groups in all laboratory parameters, except for the level of IкB- $\beta$.

Serum amylase activities were greatly elevated in cerulein-treated WT and NHERF$1-\mathrm{KO}$ vs. the control groups (Fig.6A). Importantly, amylase activity was significantly higher in the cerulein-treated NHERF-1-KO vs. WT mice. Pancreatic MPO activity was significantly increased in cerulein-treated vs. control groups, but not different in WT compared to KO mice exposed to cerulein (Fig.6B). Pancreatic HSP72 expression (a sensitive marker of tissue injury) was significantly increased in cerulein-treated vs. control groups (Fig.6C), and significant differences were also observed between cerulein-treated WT and NHERF-1-KO groups.

Key events in the pathogenesis of AP include premature activation of trypsinogen $[23,24]$ and the activation of the proinflammatory transcription factor nuclear factor- $\kappa \mathrm{B}$ $(\mathrm{NF}-\kappa \mathrm{B})$ [25]. To exclude any potential effects of NHERF-1 deletion on early trypsinogen 
and NF- $\kappa \mathrm{B}$ activation (regulated by $\mathrm{IkBs}$ ), we measured pancreatic trypsin activity (Fig.6D) and expression of IkBs (Suppl.Figs.3A-B) in mice injected i.p. with 1x50 $\mu \mathrm{g} / \mathrm{kg}$ cerulein. Trypsin activity was increased by about 4 -fold $0.5 \mathrm{~h}$ after the injection of cerulein compared to the control group (Fig.6D), however, there were no significant differences between WT and NHERF-1-KO mice. Also, with respect to IкB- $\alpha$ expression, there was no significant differences between WT and NHERF-1-KO animals in cerulein-treated groups (Suppl.Fig.3A). The basal level of IкB- $\beta$ was significantly higher in NHERF-1-KO vs. WT control mice, and no differences were observed in cerulein-treated WT and NHERF-1-KO groups (Suppl.Fig.3B). These data demonstrate that the difference in AP severity between WT and NHERF-1-KO mice is independent of pancreatic trypsinogen and NF- $\kappa \mathrm{B}$ activation.

The expression of the proinflammatory cytokine IL-1 $\beta$ was significantly elevated in the pancreas of cerulein-treated WT and NHERF-1-KO mice vs. the control groups (Suppl.Fig.3C), but there was no difference between the cerulein-treated WT vs. NHERF1-KO mice.

Of note, i.p. administration of $7 \times 50 \mu \mathrm{g} / \mathrm{kg}$ cerulein in WT and NHERF-1-KO mice caused similar effects in the investigated histological and laboratory parameters as shown for the higher cerulein dose. A summary of these results can be found in Suppl.Figs.4-5. Overall, our results clearly demonstrate that the severity of cerulein-induced AP is lower in mice expressing NHERF-1.

To exclude any possible deleterious effects of NHERF-1 deletion on cholecystokinin receptor function, we tested the sensitivity of acinar cells to cerulein. Amylase secretion of acinar cells from WT and NHERF-1-KO animals showed no significant differences in response to cerulein stimulation (Suppl.Fig.6).

Intraductal administration of $4 \%$ sodium-taurocholate causes more extensive acinar cell necrosis in NHERF-1-knock-out compared to wild-type mice

We also investigated if NHERF-1-KO mice responded differently than WT mice when AP was induced by intraductal infusion of $4 \%$ Na-taurocholate. Postoperative 
mortality after administration of Na-taurocholate in KO mice (2/14 animals) was not significantly different vs. WT animals (0/10).

Intraductal infusion of PS caused no postoperative mortality, but mild pancreatic edema and inflammation was seen on histology without any significant necrosis (Fig.7A,B). The rate of leukocyte infiltration was significantly higher in the NHERF-1-KO vs. WT mice (Table1). The infusion of $4 \%$ Na-taurocholate into the pancreatic duct induced necrotizing AP in the head (Fig.7C,D), but not in the tail of the pancreas (not shown). The latter finding is in accord with that of others [20]. Therefore, only the pancreatic heads were used for analysis. Approximately $24 \%$ of acinar cells were necrotic in WT (Fig.7C,E) and about $47 \%$ in NHERF-1-KO mice (Figs.7D,E). Table1 summarizes the histopathological changes in the various groups. Significantly higher rates of leukocyte infiltration were detected in Na-taurocholate-treated vs. PS-treated WT groups. In contrast, there were no differences in leukocyte infiltration between the Na-taurocholate-treated vs. PS-treated NHERF-1-KO groups, and Na-taurocholate-treated NHERF-1-KO vs. WT groups.

Serum amylase activities were significantly higher in Na-taurocholate-treated vs. control WT and NHERF-1-KO groups (Suppl.Fig.7A), but there were no differences between Na-taurocholate-treated NHERF-1-KO and WT mice. We did not observe any significant differences in MPO activity between WT and NHERF-1-KO mice after intraductal PS infusion (Suppl.Fig.7B). However, MPO activity was increased in Nataurocholate-treated vs. control NHERF-1-KO mice, and even higher in the KO compared to the WT Na-taurocholate-treated mice. Pancreatic IL-1 $\beta$ expression was elevated in Nataurocholate-treated WT and NHERF-1-KO mice vs. the control groups (Suppl.Fig.7C). However, there were no significant differences in the levels of IL-1 $\beta$ of Na-taurocholatetreated WT and NHERF-1-KO animals.

These data indicate that NHERF-1 expression reduces Na-taurocholate-induced pancreatic injury, but does not necessarily influence other laboratory parameters of the disease.

Functions of inflammatory cells are unaltered by deletion of NHERF-1 
Since inflammatory cells are implicated in the pathogenesis of AP and NHERF-1 expression has been shown in neutrophils [26], we checked the bacterial killing efficiency of polymorphonuclear cells and the phagocytic activity of peritoneal macrophages. The results in Suppl.Fig.8 demonstrate that knocking out NHERF-1 did not alter these functions.

NHERF-1 expression does not influence intracellular calcium signaling and the degree of cell damage caused by high concentrations of cerulein or sodiumtaurocholate in isolated acini

To further investigate whether acinar cells are affected by the deletion of NHERF1 , we tested the effects of cerulein and Na-taurocholate on the critical intracellular $\mathrm{Ca}^{2+}$ signaling pathway in induction of AP, and on cell damage of isolated acini prepared from WT and NHERF-1-KO mice. Suppl.Fig.9. shows no significant differences in elevation of $\left[\mathrm{Ca}^{2+}\right]_{\mathrm{i}}$ induced by cerulein or Na-taurocholate on isolated acinar cell from WT and NHERF-1-KO mice ( $\mathrm{n}=5-8)$. Next, we looked at the extent of in vitro cell damage induced by the administration of high concentrations (based on literature data) of cerulein $\left(10^{-8} \mathrm{M}\right)$ [27] and Na-taurocholate (1mM) [28]. Acinar viability of WT and NHERF-1-KO mice was $99.5 \pm 0.5 \%$ and $97.6 \pm 1.0 \%$ immediately after isolation, respectively $(n=7)$; LDH release was $9.2 \pm 1.2 \%$ and $7.6 \pm 1.0 \%$, respectively $(n=7)$. Acinar viability significantly decreased with time and in response to cerulein or Na-taurocholate administration (Fig.8). However, we did not find any significant differences in cell viability parameters of treated WT and NHERF-1-KO acini. 


\section{DISCUSSION}

We have demonstrated that NHERF-1 mRNA is highly expressed in mouse pancreatic ducts, but not acini. Furthermore, the genetic deletion of NHERF-1 greatly reduced the localisation of CFTR in the luminal ductal cell membrane and also decreased both in vitro and in vivo pancreatic bicarbonate and fluid secretion. Both basal and cAMPstimulated secretion was reduced in the transgenic animals, but this effect was not caused by alterations in pancreatic blood flow. The diminished ductal secretion in NHERF-1-KO mice was associated with increased severity of necrotizing AP in two independent models of the disease. Importantly, early acinar events associated with AP, such as intracellular $\mathrm{Ca}^{2+}$ signaling, trypsinogen and NF- $\kappa \mathrm{B}$ activation were unaltered by deletion of NHERF1, but late events such as apoptosis and necrosis were increased in the KO animals. Notably, deletion of NHERF-1 had no deleterious effect on functions of acinar and inflammatory cells independent of AP, indicating that increased severity of the disease is specifically due to impaired ductal secretion.

NHERF-1 has been identified as a CFTR-interacting PDZ domain protein, which is involved in the apical targeting of CFTR, signal complex formation with a variety of receptors, and possibly the interaction with other membrane transport proteins, in a celland signal-specific manner [26, 29-34]. In our study, the absence of NHERF-1 greatly reduced CFTR abundance in the apical membrane of pancreatic ducts, whereas CFTR mRNA expression was unaltered. The gross mislocalization of CFTR resulted in decreased ductal fluid and $\mathrm{HCO}_{3}{ }^{-}$secretion. Consistent with our findings, mutations in CFTR that cause cystic fibrosis, impair the stability of the $\mathrm{Cl}^{-}$channel in the plasma membrane and also result in markedly reduced bicarbonate and fluid secretion [35]. Our study does not differentiate between a loss of $\mathrm{HCO}_{3}{ }^{-}$and fluid secretion via CFTR or via a disruption between CFTR and other transporters involved in pancreatic bicarbonate and fluid secretion, such as SLC26 anion exchangers. Of note, both DRA and PAT-1 are known to have PDZ domain binding motifs [4], and to bind to NHERF-1 [8, 36, 37]. In addition, activation of CFTR by SLC26 transporters was shown to be facilitated by PDZ ligands [3]. The reduced expression of CFTR in the apical membrane in NHERF-1-KO pancreatic ducts thus will likely decrease the activities of PAT-1 and DRA [38, 39]. 
Several groups have shown that binding of CFTR to NHERF may regulate CFTR activity. Two studies $[7,40]$ have demonstrated that NHERF-1 is required for full activation of transepithelial $\mathrm{Cl}^{-}$and $\mathrm{HCO}_{3}{ }^{-}$secretion by cAMP- and cGMP-linked agonists in the duodenum and jejunum. This reduced activation of anion currents in NHERF-1-KO mice was independent of the total amount of CFTR expression in epithelial cells, and appeared to be due to a defect in apical targeting and/or retention of CFTR [40]. In addition, the NHERF-1 assisted formation of receptor-transporter signaling complexes in the apical membrane were disrupted [7]. A recent study has shown that CFTR activity is also dependent on NHERF-1 regulated cAMP compartmentalization and local protein kinase A activity in human airway epithelial cells [41]. The particularly high expression of NHERF1 and CFTR in pancreatic ducts is quite different from that found in the small intestine [42, 43]. These findings suggest to us that CFTR-NHERF-1 interaction may be crucial to pancreatic ductal secretion.

Accumulating evidence suggests that pancreatic ducts not only have prominent roles physiologically, but also pathophysiologically. It is well known that insufficient electrolyte and fluid secretion by ductal cells in cystic fibrosis (caused by mutations in the CFTR gene) leads to destruction of acini [9]. Numerous CFTR mutations predispose to chronic pancreatitis [44]. Pancreatic biopsies from patients with autoimmune pancreatitis showed mislocalization of CFTR in the ducts and secretin-stimulated fluid and $\mathrm{HCO}_{3}{ }^{-}$ secretion was reduced in these patients [45]. Until quite recently, the pathophysiological relevance of pancreatic ducts in AP has been neglected. It is commonly assumed that the primary target of all stressors is the acinar cells since they are damaged in all forms of AP. However, both clinical and experimental data suggest that pancreatic ductal cells may also have fundamental roles in the development of AP [11]. Cavesto et al [10] have found statistically significant association of CFTR gene mutations in patients with recurrent AP. Pancreatic fluid secretion is greatly increased at the initiation of AP [46]. Also, in vitro administration of agents inducing AP such as bile acids, viruses or ethanol to pancreatic duct cells stimulate bicarbonate secretion $[11,16]$. Our hypothesis is that ductal secretion serves to defend the pancreas by washing out toxic agents such as activated digestive enzymes. If this ductal defence mechanism is insufficient, ductal secretion will be inhibited and the harmful enzymes cannot leave the pancreas. The beneficial effect of ductal fluid 
hypersecretion is indicated by the fact that secretin, a major mediator of pancreatic ductal secretion, has been shown to protect against cerulein-induced AP [47, 48]. Furthermore, the severity of AP in galanin (a neuropeptide which has a potent inhibitory effect on pancreatic $\mathrm{HCO}_{3}{ }^{-}$secretion) $\mathrm{KO}$ mice was significantly reduced compared to WT littermates [49].

A striking finding of this study was that the severity of cerulein-induced acute necrotizing pancreatitis was significantly greater in animals lacking NHERF-1 (and thus reduced pancreatic ductal secretion), which suggests that normal ductal secretion in WT mice protects acinar cells against necrosis and apoptosis. This effect was independent of a change in cerulein sensitivity of acinar cells, and shows that NHERF-1 expression is not necessary for cholecystokinin receptor function. Furthermore, we did not find any significant differences in intracellular $\mathrm{Ca}^{2+}$ signaling and pancreatic activation of trypsinogen and NF- $\kappa B$ in mice lacking NHERF-1. Taken together, the latter findings show that early acinar events leading to AP are unaltered by NHERF-1 expression. Similar to our findings, another group has shown that transgenic mice with reduced CFTR expression were more susceptible to cerulein-induced AP [50, 51]. As CFTR-KO mice exhibited constitutive overexpression of pancreatic proinflammatory mediators, this is not that surprising. However, we did not find any differences in basal pancreatic proinflammatory parameters between WT and NHERF-1-KO mice. Furthermore, in the studies by DiMagno et al, only the cerulein-induced AP model was tested and the acinar- vs. ductal-specific effects were not investigated. To confirm that the effect of diminished secretion on AP severity was not specific to the cerulein-induced model, we also determined disease severity in the clinically more relevant Na-taurocholate model [52]. Similar to the results observed in the cerulein-induced pancreatitis model, the degree of acinar cell damage in Na-taurocholate-induced AP was significantly greater in NHERF-1-KO vs. WT mice. Notably, the lower degree of necrosis was not necessarily accompanied by markedly reduced levels of inflammatory infiltration. Interestingly, leukocyte infiltration was higher in NHERF-1-KO vs. WT mice injected intraductally with PS. The latter data indicate that $\mathrm{KO}$ animals may even be more sensitive to increased ductal pressure.

Importantly, NHERF-1 expression did not influence the degree of cell damage caused by high concentrations of cerulein or sodium-taurocholate in isolated acini. These 
data indicate that the general deletion of NHERF-1 does not affect acinar cell damage caused by the latter agents. Therefore, it is likely that factors other than variations in the direct effects of cerulein or sodium-taurocholate on acinar cells are responsible for the differences in AP severities of WT and NHERF-1-KO mice.

\section{CONCLUSIONS}

Our results show for the first time that NHERF-1 plays a critical role in regulating the apical localization of CFTR in mouse pancreatic duct cells and ductal secretion which significantly influences the severity of acute necrotizing pancreatitis. Importantly, we provide in vivo data that strongly suggests the involvement of pancreatic ductal secretion in the pathogenesis of AP. The results obtained from this study may eventually open up new therapeutic possibilities (targeting ductal secretion) in the treatment of pancreatic inflammation which have to date mainly focused on acinar cells.

\section{ACKNOWLEDGEMENTS}

We are greatly indebted to Dr. José San Román (Salamanca, Spain) and Prof. Fred Gorelick et al (New Haven, CT, USA) for their valuable advice in setting up the in vitro fluid secretory measurement and acinar cell isolation techniques, respectively. The authors thank Dr. Gizella Karácsony (Szeged, Hungary) for her help with the TUNEL assay, Dr. Colin R. Muirhead (Newcastle upon Tyne, UK) for statistical review of the paper, Prof. Shmuel Muallem for thoughtful comments regarding the manuscript preparation and Brigitte Rausch, Natascha Cirpka and Silke Thiele (Hannover, Germany) for mouse breeding and genotyping. The rabbit anti-HSP72 antibody was a generous gift from Dr. István Kurucz (Budapest, Hungary). 


\section{REFERENCES}

1. Pandol SJ, Saluja AK, Imrie CW, Banks PA: Acute pancreatitis: bench to the bedside. Gastroenterology 2007, 132(3):1127-1151.

2. Lee MG, Ohana E, Park HW, Yang D, Muallem S: Molecular mechanism of pancreatic and salivary gland fluid and $\mathrm{HCO} 3$ secretion. Physiological reviews 2012, 92(1):39-74.

3. Ko SB, Zeng W, Dorwart MR, Luo X, Kim KH, Millen L, Goto H, Naruse S, Soyombo A, Thomas PJ et al: Gating of CFTR by the STAS domain of SLC26 transporters. Nat Cell Biol 2004, 6(4):343-350.

4. Lamprecht $\mathrm{G}$, Seidler $\mathrm{U}$ : The emerging role of PDZ adapter proteins for regulation of intestinal ion transport. Am J Physiol Gastrointest Liver Physiol 2006, 291(5):G766-777.

5. Guggino WB, Stanton BA: New insights into cystic fibrosis: molecular switches that regulate CFTR. Nature reviews Molecular cell biology 2006, 7(6):426-436.

6. Hall RA, Premont RT, Chow CW, Blitzer JT, Pitcher JA, Claing A, Stoffel RH, Barak LS, Shenolikar S, Weinman EJ et al: The beta2-adrenergic receptor interacts with the $\mathrm{Na}^{+} / \mathrm{H}^{+}$-exchanger regulatory factor to control $\mathrm{Na}^{+} / \mathrm{H}^{+}$exchange. Nature 1998, 392(6676):626-630.

7. Singh AK, Riederer B, Krabbenhoft A, Rausch B, Bonhagen J, Lehmann U, de Jonge HR, Donowitz M, Yun C, Weinman EJ et al: Differential roles of NHERF1, NHERF2, and PDZK1 in regulating CFTR-mediated intestinal anion secretion in mice. J Clin Invest 2009, 119(3):540-550.

8. Rossmann H, Jacob P, Baisch S, Hassoun R, Meier J, Natour D, Yahya K, Yun C, Biber J, Lackner KJ et al: The CFTR associated protein CAP70 interacts with the apical $\mathrm{Cl}^{-} / \mathrm{HCO}_{3}{ }^{-}$exchanger DRA in rabbit small intestinal mucosa. Biochemistry 2005, 44(11):4477-4487. 
9. Steward MC, Ishiguro H: Molecular and cellular regulation of pancreatic duct cell function. Curr Opin Gastroenterol 2009, 25(5):447-453.

10. Cavestro GM, Zuppardo RA, Bertolini S, Sereni G, Frulloni L, Okolicsanyi S, Calzolari C, Singh SK, Sianesi M, Del Rio P et al: Connections between genetics and clinical data: Role of MCP-1, CFTR, and SPINK-1 in the setting of acute, acute recurrent, and chronic pancreatitis. Am J Gastroenterol 2010, 105(1):199-206.

11. Hegyi P, Pandol S, Venglovecz V, Rakonczay Z, Jr.: The acinar-ductal tango in the pathogenesis of acute pancreatitis. Gut 2011, 60(4):544-552.

12. Shenolikar S, Voltz JW, Minkoff CM, Wade JB, Weinman EJ: Targeted disruption of the mouse NHERF-1 gene promotes internalization of proximal tubule sodiumphosphate cotransporter type IIa and renal phosphate wasting. Proc Natl Acad Sci U S A 2002, 99(17):11470-11475.

13. Gray MA, Winpenny JP, Porteous DJ, Dorin JR, Argent BE: CFTR and calciumactivated chloride currents in pancreatic duct cells of a transgenic CF mouse. Am J Physiol 1994, 266(1 Pt 1):C213-221.

14. Pandol SJ, Jensen RT, Gardner JD: Mechanism of [Tyr4]bombesin-induced desensitization in dispersed acini from guinea pig pancreas. J Biol Chem 1982, 257(20):12024-12029.

15. Cinar A, Chen M, Riederer B, Bachmann O, Wiemann M, Manns M, Kocher O, Seidler U: NHE3 inhibition by cAMP and $\mathrm{Ca}^{2+}$ is abolished in PDZ-domain protein PDZK1-deficient murine enterocytes. $J$ Physiol 2007, 581(Pt 3):1235-1246.

16. Venglovecz V, Rakonczay Z, Jr., Ózsvári B, Takács T, Lonovics J, Varró A, Gray MA, Argent BE, Hegyi P: Effects of bile acids on pancreatic ductal bicarbonate secretion in guinea pig. Gut 2008, 57(8):1102-1112.

17. Hegyi P, Rakonczay Z, Jr., Gray MA, Argent BE: Measurement of intracellular pH in pancreatic duct cells: a new method for calibrating the fluorescence data. Pancreas 2004, 28(4):427-434.

18. Hegyi P, Rakonczay Z, Jr., Tiszlavicz L, Varró A, Tóth A, Rácz G, Varga G, Gray MA, Argent BE: Protein kinase $\mathrm{C}$ mediates the inhibitory effect of substance $\mathrm{P}$ on 
HCO3- secretion from guinea pig pancreatic ducts. Am J Physiol Cell Physiol 2005, 288(5):C1030-1041.

19. Fernandez-Salazar MP, Pascua P, Calvo JJ, Lopez MA, Case RM, Steward MC, San Roman JI: Basolateral anion transport mechanisms underlying fluid secretion by mouse, rat and guinea-pig pancreatic ducts. $J$ Physiol 2004, 556(Pt 2):415-428.

20. Perides G, van Acker GJ, Laukkarinen JM, Steer ML: Experimental acute biliary pancreatitis induced by retrograde infusion of bile acids into the mouse pancreatic duct. Nat Protoc 2010, 5(2):335-341.

21. Rakonczay Z, Jr., Hegyi P, Dosa S, Ivanyi B, Jarmay K, Biczo G, Hracsko Z, Varga IS, Karg E, Kaszaki J et al: A new severe acute necrotizing pancreatitis model induced by L-ornithine in rats. Crit Care Med 2008, 36(7):2117-2127.

22. Kuebler WM, Abels C, Schuerer L, Goetz AE: Measurement of neutrophil content in brain and lung tissue by a modified myeloperoxidase assay. Int J Microcirc Clin Exp 1996, 16(2):89-97.

23. Hofbauer B, Saluja AK, Lerch MM, Bhagat L, Bhatia M, Lee HS, Frossard JL, Adler G, Steer ML: Intra-acinar cell activation of trypsinogen during caeruleininduced pancreatitis in rats. Am J Physiol 1998, 275 (2 Pt 1):G352-362.

24. Saluja AK, Donovan EA, Yamanaka K, Yamaguchi Y, Hofbauer B, Steer ML: Cerulein-induced in vitro activation of trypsinogen in rat pancreatic acini is mediated by cathepsin B. Gastroenterology 1997, 113(1):304-310.

25. Rakonczay Z, Jr., Hegyi P, Takács T, McCarroll J, Saluja AK: The role of NFkappaB activation in the pathogenesis of acute pancreatitis. Gut 2008, 57(2):259267.

26. Wu Y, Wang S, Farooq SM, Castelvetere MP, Hou Y, Gao JL, Navarro JV, Oupicky D, Sun F, Li C: A chemokine receptor CXCR2 macromolecular complex regulates neutrophil functions in inflammatory diseases. J Biol Chem 2012, 287(8):57445755. 
27. Thrower EC, Wang J, Cheriyan S, Lugea A, Kolodecik TR, Yuan J, Reeve JR, Jr., Gorelick FS, Pandol SJ: Protein kinase C delta-mediated processes in cholecystokinin-8-stimulated pancreatic acini. Pancreas 2009, 38(8):930-935.

28. Barrow SL, Voronina SG, Xavier GD, Chvanov MA, Longbottom RE, Gerasimenko OV, Petersen OH, Rutter GA, Tepikin AV: ATP depletion inhibits $\mathrm{Ca}^{2+}$ release, influx and extrusion in pancreatic acinar cells but not pathological $\mathrm{Ca}^{2+}$ responses induced by bile. Pflug Arch Eur J Phy 2008, 455(6):1025-1039.

29. Raghuram V, Mak DO, Foskett JK: Regulation of cystic fibrosis transmembrane conductance regulator single-channel gating by bivalent PDZ-domain-mediated interaction. Proc Natl Acad Sci U S A 2001, 98(3):1300-1305.

30. Moyer BD, Denton J, Karlson KH, Reynolds D, Wang S, Mickle JE, Milewski M, Cutting GR, Guggino WB, Li M et al: A PDZ-interacting domain in CFTR is an apical membrane polarization signal. J Clin Invest 1999, 104(10):1353-1361.

31. Milewski MI, Mickle JE, Forrest JK, Stafford DM, Moyer BD, Cheng J, Guggino WB, Stanton BA, Cutting GR: A PDZ-binding motif is essential but not sufficient to localize the C terminus of CFTR to the apical membrane. J Cell Sci 2001, 114(Pt 4):719-726.

32. Swiatecka-Urban A, Duhaime M, Coutermarsh B, Karlson KH, Collawn J, Milewski M, Cutting GR, Guggino WB, Langford G, Stanton BA: PDZ domain interaction controls the endocytic recycling of the cystic fibrosis transmembrane conductance regulator. J Biol Chem 2002, 277(42):40099-40105.

33. Benharouga M, Sharma M, So J, Haardt M, Drzymala L, Popov M, Schwapach B, Grinstein S, Du K, Lukacs GL: The role of the $\mathrm{C}$ terminus and $\mathrm{Na}^{+} / \mathrm{H}^{+}$exchanger regulatory factor in the functional expression of cystic fibrosis transmembrane conductance regulator in nonpolarized cells and epithelia. J Biol Chem 2003, 278(24):22079-22089.

34. Ostedgaard LS, Randak C, Rokhlina T, Karp P, Vermeer D, Ashbourne Excoffon KJ, Welsh MJ: Effects of C-terminal deletions on cystic fibrosis transmembrane 
conductance regulator function in cystic fibrosis airway epithelia. Proc Natl Acad Sci U S A 2003, 100(4):1937-1942.

35. Lukács GL, Verkman AS: CFTR: folding, misfolding and correcting the DeltaF508 conformational defect. Trends Mol Med 2012, 18(2):81-91.

36. Lamprecht G, Heil A, Baisch S, Lin-Wu E, Yun CC, Kalbacher H, Gregor M, Seidler U: The down regulated in adenoma (dra) gene product binds to the second PDZ domain of the NHE3 kinase A regulatory protein (E3KARP), potentially linking intestinal $\mathrm{Cl}^{-} / \mathrm{HCO}_{3}^{-}$exchange to $\mathrm{Na}^{+} / \mathrm{H}^{+}$exchange. Biochemistry 2002, 41(41):12336-12342.

37. Lohi H, Lamprecht G, Markovich D, Heil A, Kujala M, Seidler U, Kere J: Isoforms of SLC26A6 mediate anion transport and have functional PDZ interaction domains. Am J Physiol Cell Physiol 2003, 284(3):C769-779.

38. Rakonczay Z, Jr., Hegyi P, Hasegawa M, Inoue M, You J, Iida A, Ignáth I, Alton EW, Griesenbach U, Ovari G et al: CFTR gene transfer to human cystic fibrosis pancreatic duct cells using a Sendai virus vector. J Cell Physiol 2008, 214(2):442455.

39. Chernova MN, Jiang L, Shmukler BE, Schweinfest CW, Blanco P, Freedman SD, Stewart AK, Alper SL: Acute regulation of the SLC26A3 congenital chloride diarrhoea anion exchanger (DRA) expressed in Xenopus oocytes. J Physiol 2003, 549(Pt 1):3-19.

40. Broere N, Hillesheim J, Tuo B, Jorna H, Houtsmuller AB, Shenolikar S, Weinman EJ, Donowitz M, Seidler U, de Jonge HR et al: Cystic fibrosis transmembrane conductance regulator activation is reduced in the small intestine of $\mathrm{Na}^{+} / \mathrm{H}^{+}$ exchanger 3 regulatory factor 1 (NHERF-1)- but Not NHERF-2-deficient mice. $J$ Biol Chem 2007, 282(52):37575-37584.

41. Monterisi S, Favia M, Guerra L, Cardone RA, Marzulli D, Reshkin SJ, Casavola V, Zaccolo M: CFTR regulation in human airway epithelial cells requires integrity of the actin cytoskeleton and compartmentalized cAMP and PKA activity. $J$ Cell Sci 2012, 125(Pt 5):1106-1117. 
42. Hillesheim J, Riederer B, Tuo B, Chen M, Manns M, Biber J, Yun C, Kocher O, Seidler U: Down regulation of small intestinal ion transport in PDZK1(CAP70/NHERF3) deficient mice. Pflugers Arch 2007, 454(4):575-586.

43. Singh AK, Riederer B, Chen M, Xiao F, Krabbenhoft A, Engelhardt R, Nylander O, Soleimani M, Seidler U: The switch of intestinal Slc26 exchangers from anion absorptive to HCO3- secretory mode is dependent on CFTR anion channel function. Am J Physiol Cell Physiol 2010, 298(5):C1057-1065.

44. Chen JM, Ferec C: Chronic pancreatitis: genetics and pathogenesis. Annu Rev Genomics Hum Genet 2009, 10:63-87.

45. Ko SB, Mizuno N, Yatabe Y, Yoshikawa T, Ishiguro H, Yamamoto A, Azuma S, Naruse S, Yamao K, Muallem S et al: Corticosteroids correct aberrant CFTR localization in the duct and regenerate acinar cells in autoimmune pancreatitis. Gastroenterology 2010, 138(5):1988-1996.

46. Czako L, Yamamoto M, Otsuki M: Exocrine pancreatic function in rats after acute pancreatitis. Pancreas 1997, 15(1):83-90.

47. Renner IG, Wisner JR, Jr., Rinderknecht H: Protective effects of exogenous secretin on ceruletide-induced acute pancreatitis in the rat. J Clin Invest 1983, 72(3):10811092.

48. Niederau C, Ferrell LD, Grendell JH: Caerulein-induced acute necrotizing pancreatitis in mice: protective effects of proglumide, benzotript, and secretin. Gastroenterology 1985, 88(5 Pt 1):1192-1204.

49. Bhandari M, Thomas AC, Hussey DJ, Li X, Jaya SP, Woods CM, Schloithe AC, Mayne GC, Carati CJ, Toouli J et al: Galanin mediates the pathogenesis of ceruleininduced acute pancreatitis in the mouse. Pancreas 2010, 39(2):182-187.

50. DiMagno MJ, Lee SH, Owyang C, Zhou SY: Inhibition of acinar apoptosis occurs during acute pancreatitis in the human homologue DeltaF508 cystic fibrosis mouse. Am J Physiol Gastrointest Liver Physiol 2010, 299(2):G400-412.

51. Dimagno MJ, Lee SH, Hao Y, Zhou SY, McKenna BJ, Owyang C: A proinflammatory, antiapoptotic phenotype underlies the susceptibility to acute 
pancreatitis in cystic fibrosis transmembrane regulator (-/-) mice. Gastroenterology 2005, 129(2):665-681.

52. Hegyi P, Perides G, Steer ML, et al: Commonly employed rodent models of experimental acute pancreatitis: Their strengths and weaknesses, relevance to human disease, selection, and appropriate use. The Pancreapedia: Exocrine Pancreas Knowledge Base 2013; DOI: 10.3998/panc.2013.4. 
FIGURE AND TABLE LEGENDS

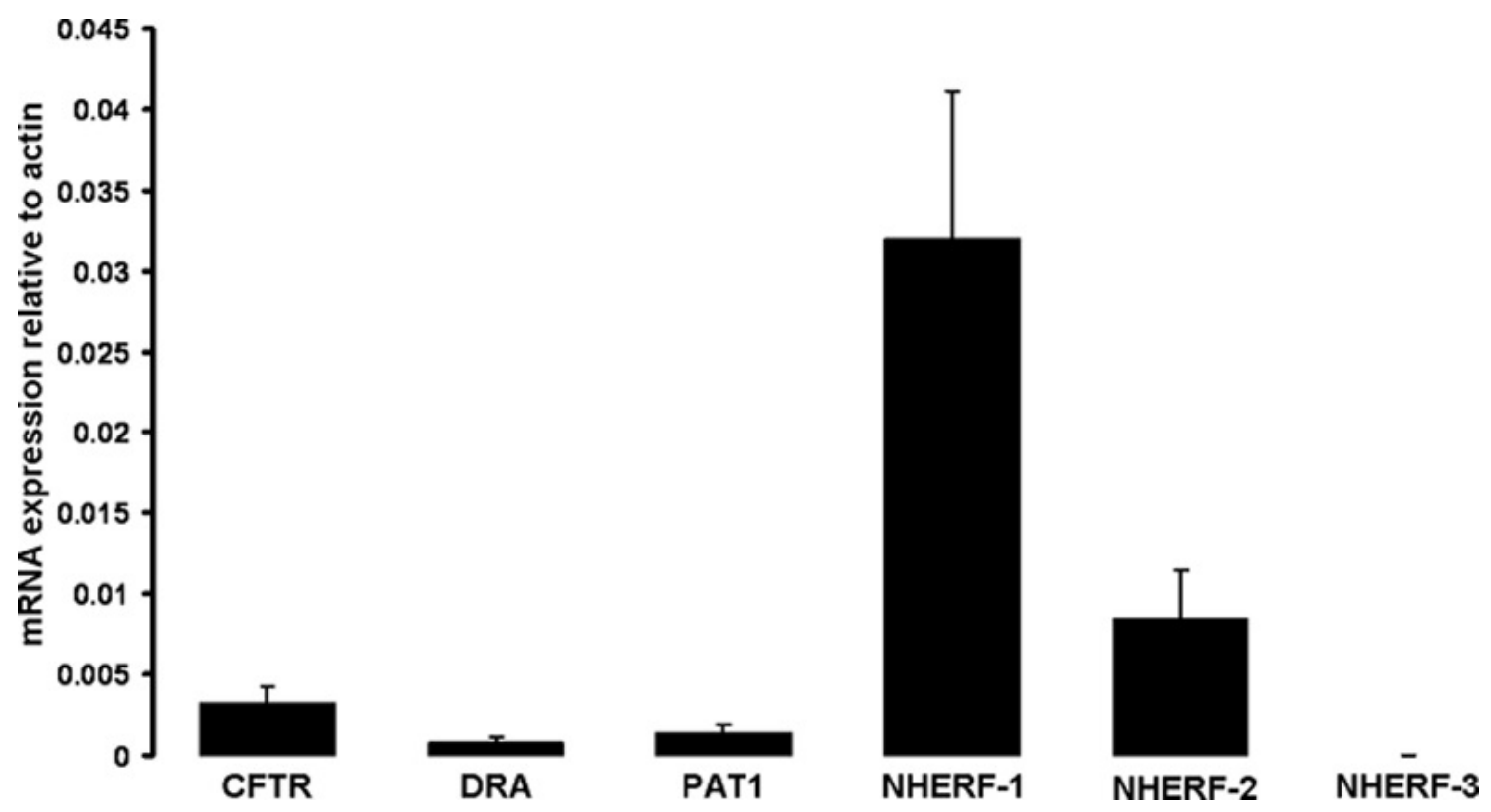

Fig. 1. mRNA expression of CFTR, DRA, PAT1, NHERF-1, NHERF-2 and NHERF-3 in isolated mouse pancreatic ducts. Total RNA was prepared from isolated interlobular pancreatic ducts of wild-type (WT) mice $(n=6)$ after overnight culture and mRNA expression of transporters/NHERF1-3 was measured by real-time RT-PCR. Data are shown as means $\pm \mathrm{SEM}$. 


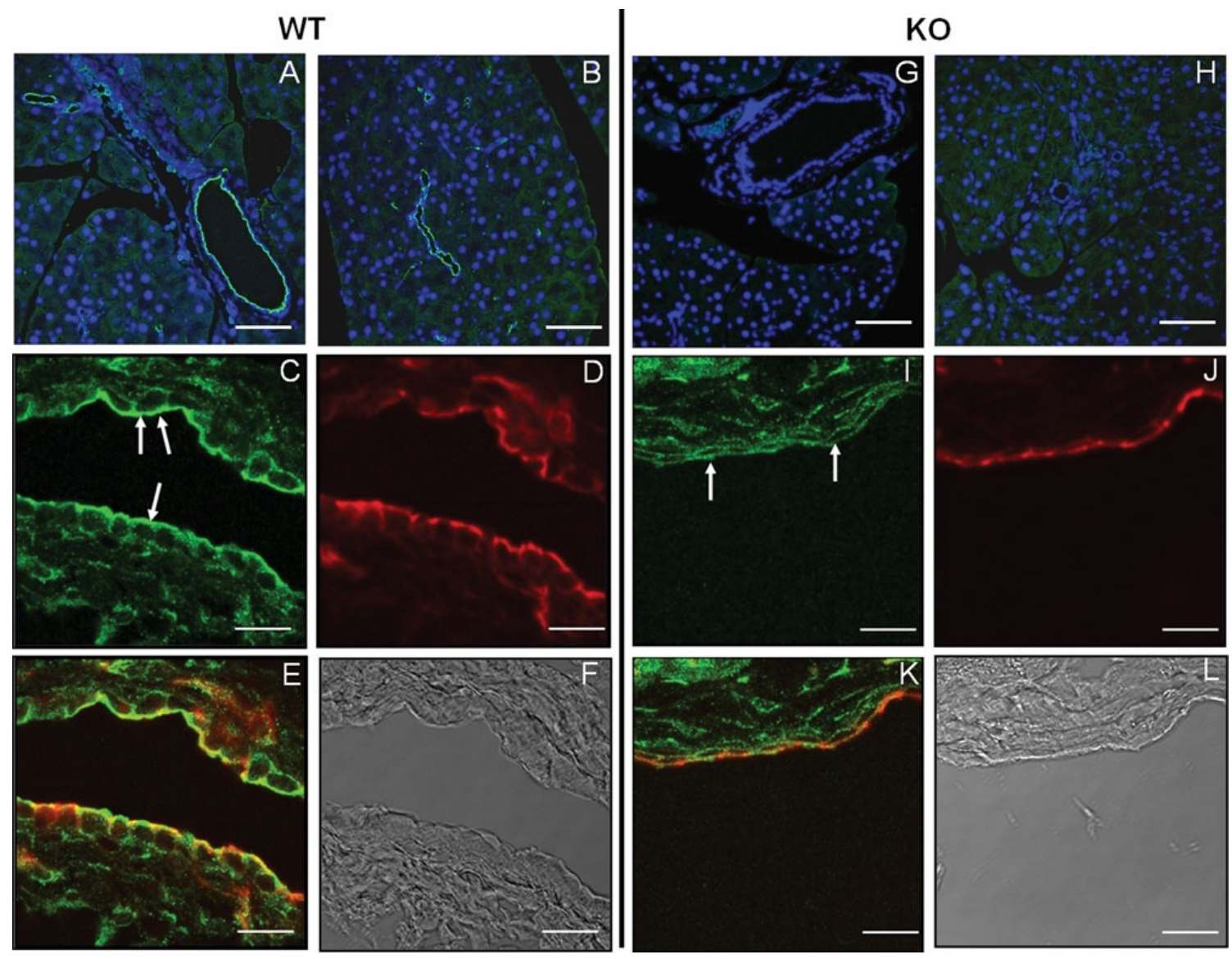

Fig. 2. NHERF-1 and CFTR staining in wild-type and NHERF-1-knock-out pancreata.

Representative immunohistochemical staining of NHERF1 (A, B, G, H) and CFTR $(\mathbf{C}, \mathbf{I})$ in the pancreas of WT and NHERF-1-knock-out (KO) mice. NHERF-1 was localized in the apical membrane of intra- and interlobular duct cells; only weak staining was noted in some acinar cells of WT mice (A, B). No or weak staining was detected in NHERF-1KO mice $(\mathbf{G}, \mathbf{H})$. CFTR staining in the pancreas of WT and NHERF-1-KO mice showed that apical (white arrow) CFTR localization (green) was reduced in NHERF-1-KO (I) vs. WT (C) ducts. Red staining shows F-actin expression (D, J). E, K show merged images of CFTR and F-actin (yellow color indicates co-localization). F, $\mathbf{L}$ are phase contrast pictures. Scale bar $=50 \mu \mathrm{m}$ 

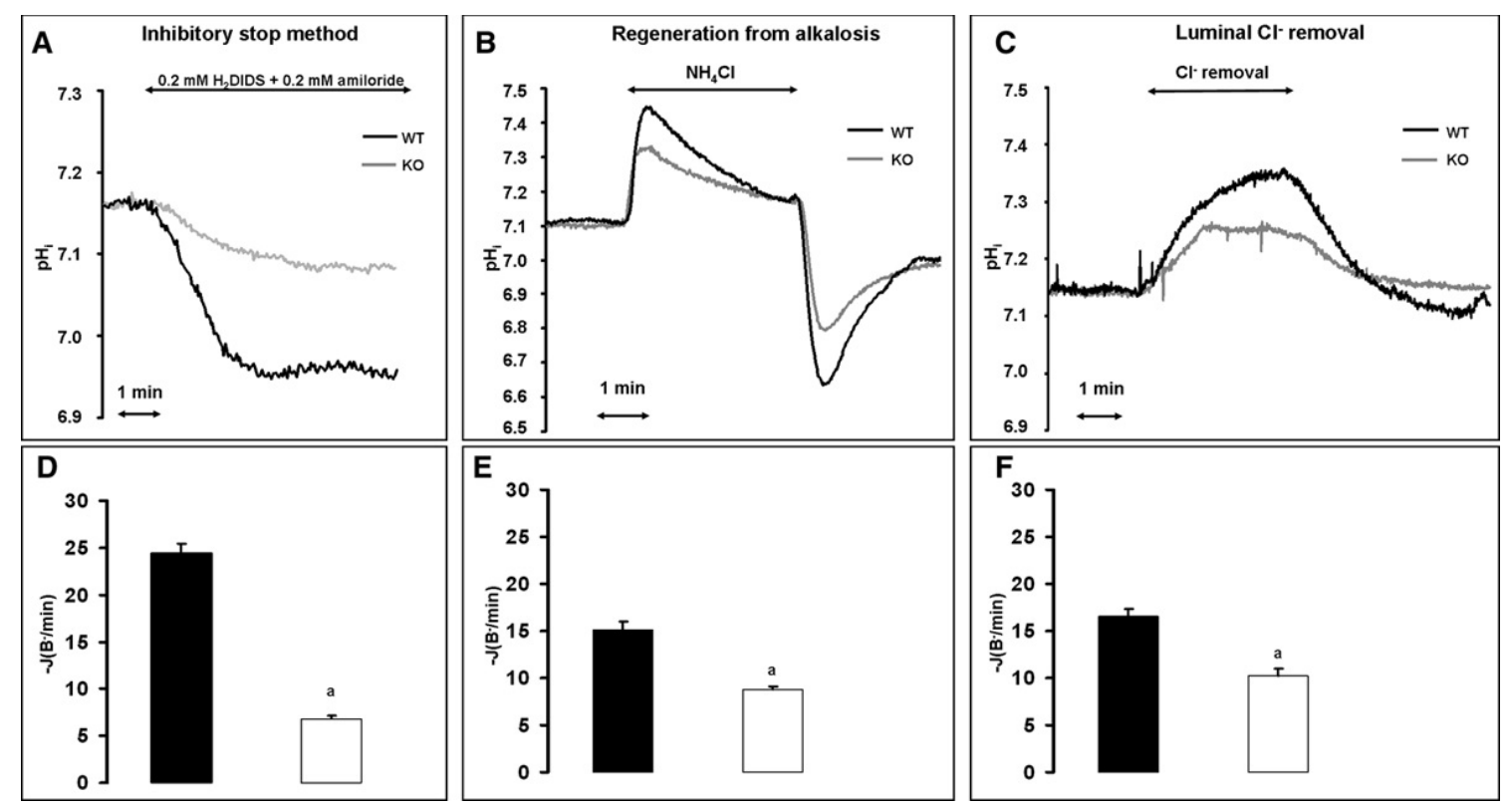

Fig. 3. Pancreatic ductal $\mathrm{HCO}_{3}^{-}$secretion is decreased in NHERF-1-knock-out

mice. Panels A-C show representative intracellular $\mathrm{pH}$ traces of isolated pancreatic ducts bathed in standard $\mathrm{HCO}_{3}-\mathrm{CO}_{2}$ solution demonstrating the effects of $0.2 \mathrm{mM}$ amiloride and $0.2 \mathrm{mM} \mathrm{H} \mathrm{H}_{2}$ DIDS administered from the basolateral membrane (A), the recovery from alkalosis via administration of $20 \mathrm{mM} \mathrm{NH}_{4} \mathrm{Cl}(\mathbf{B})$, or after luminal $\mathrm{Cl}^{-}$removal $(\mathbf{C})$. Bar charts show summary data for the base fluxes $\left[-\mathrm{J}\left(\mathrm{B}^{-} / \mathrm{min}\right)\right]$ after exposure of the transport inhibitors $(\mathbf{D}), 20 \mathrm{mM} \mathrm{NH}_{4} \mathrm{Cl}(\mathbf{E})$ or luminal $\mathrm{Cl}^{-}$removal $(\mathbf{F})$ in $\mathrm{WT}$ (closed columns) and NHERF-1-KO (open columns) mice. Means \pm SEM are from 30-50 regions of interest from 5-8 ducts. a: $\mathrm{P}<0.05$ vs. the respective WT group. 

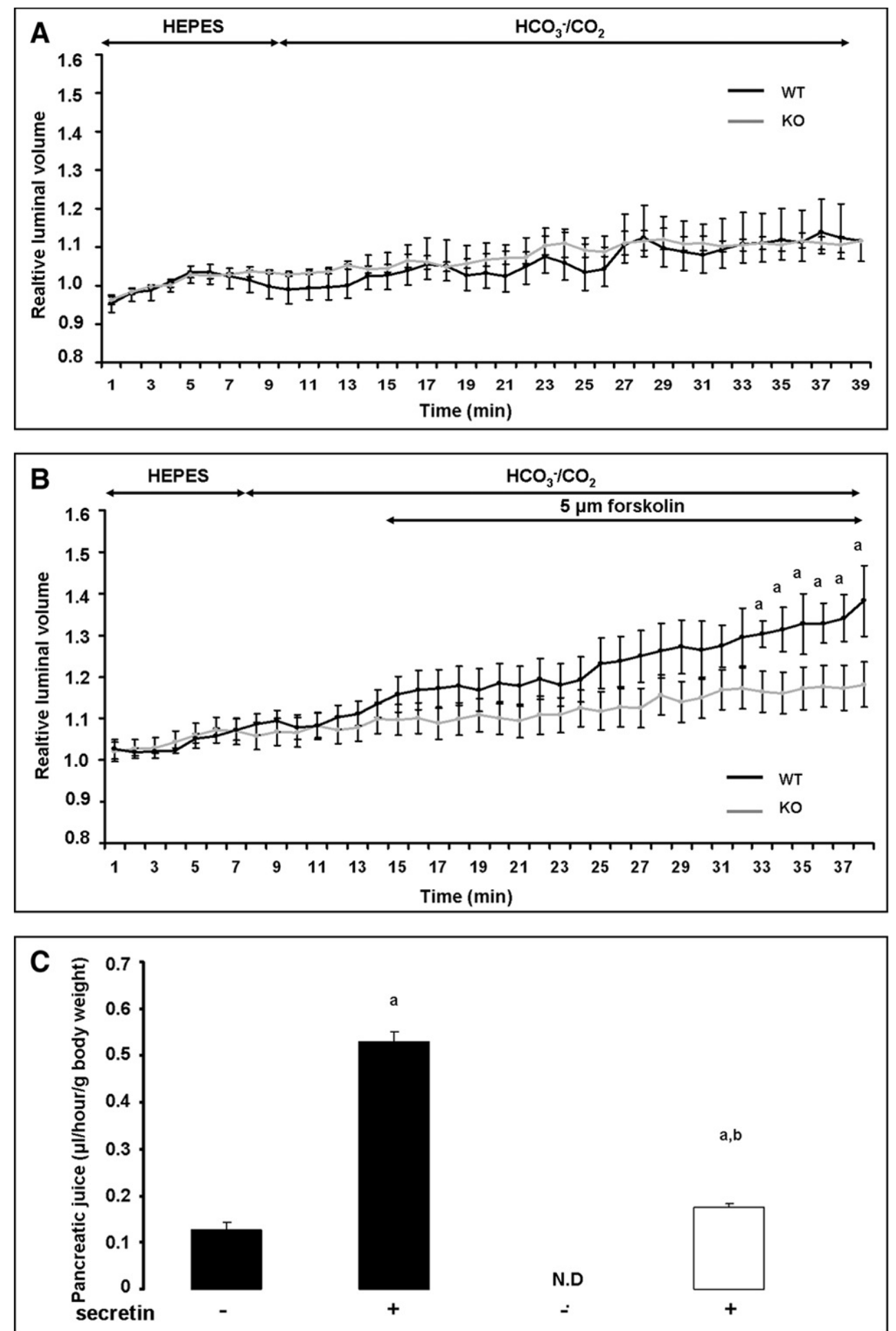

Fig. 4. Fluid secretion is decreased in NHERF-1-knock-out vs. wild-type mice.

$\mathbf{A}$ and $\mathbf{B}$ show changes in the relative luminal volume of pancreatic ducts from WT (black line, $\mathrm{n}=8$ from 3 animals) and NHERF-1-KO (gray line, $\mathrm{n}=8$ from 3 animals) mice. Initially, 
ducts were perfused with HEPES-buffered solution, then perfusion was switched to standard $\mathrm{HCO}_{3}{ }^{-} / \mathrm{CO}_{2}$-buffered solution (A). In some cases the ductal secretion was stimulated with $5 \mu \mathrm{M}$ forskolin (B). Panel $\mathbf{C}$ shows the volume of pancreatic juice collected in vivo under basal (secretin -) and secretin-stimulated (secretin +, $0.75 \mathrm{CU} / \mathrm{kg}$ i.v.) conditions from WT (closed columns) and NHERF-1-KO (open column) mice anesthetized with urethane. Means \pm SEM are from 5-6 animals. $\mathrm{P}<0.05$ vs. a: the respective secretingroup or b: vs. the WT secretin+ group. N.D.: not detected in case of NHERF-1-KO mice.
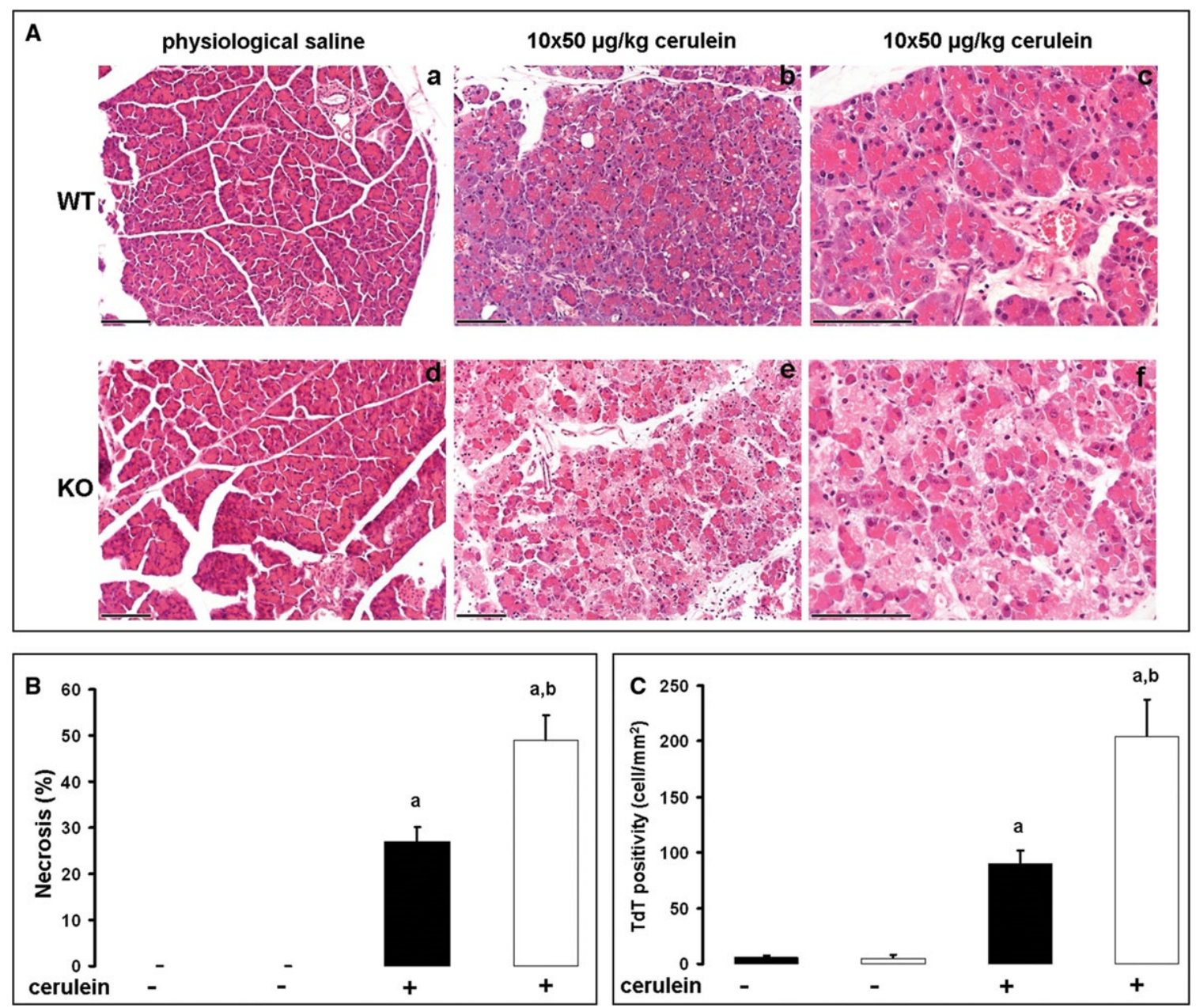

Fig. 5. Histopathologic changes of the pancreas in response to intraperitoneal administration of cerulein in wild-type and NHERF-1-knock-out mice. Acute 
pancreatitis was induced by administering 10 hourly i.p. injections of cerulein $(50 \mu \mathrm{g} / \mathrm{kg}$ per injection, cerulein+). Control mice were given PS (cerulein-) instead of cerulein. Mice were exsanguinated through the inferior vena cava $12 \mathrm{~h}$ after the first i.p. injection. (A)The pictures show representative light micrographs (H\&E staining) of the pancreata of WT control (a) and cerulein-treated (b-c) and NHERF-1-KO control (d) and cerulein-treated (e-f) mice. Scale bar $=100 \mu \mathrm{m}$. The bar diagrams show the rates of pancreatic necrosis (B) $(\mathrm{n}=9-10)$ and apoptosis $(\mathbf{C})(\mathrm{n}=4-6)$. Data are shown as means \pm SEM. $\mathrm{P}<0.05$ vs. a: the respective control group or b: vs. the WT cerulein+ group. WT (closed columns), NHERF1-KO (open columns).
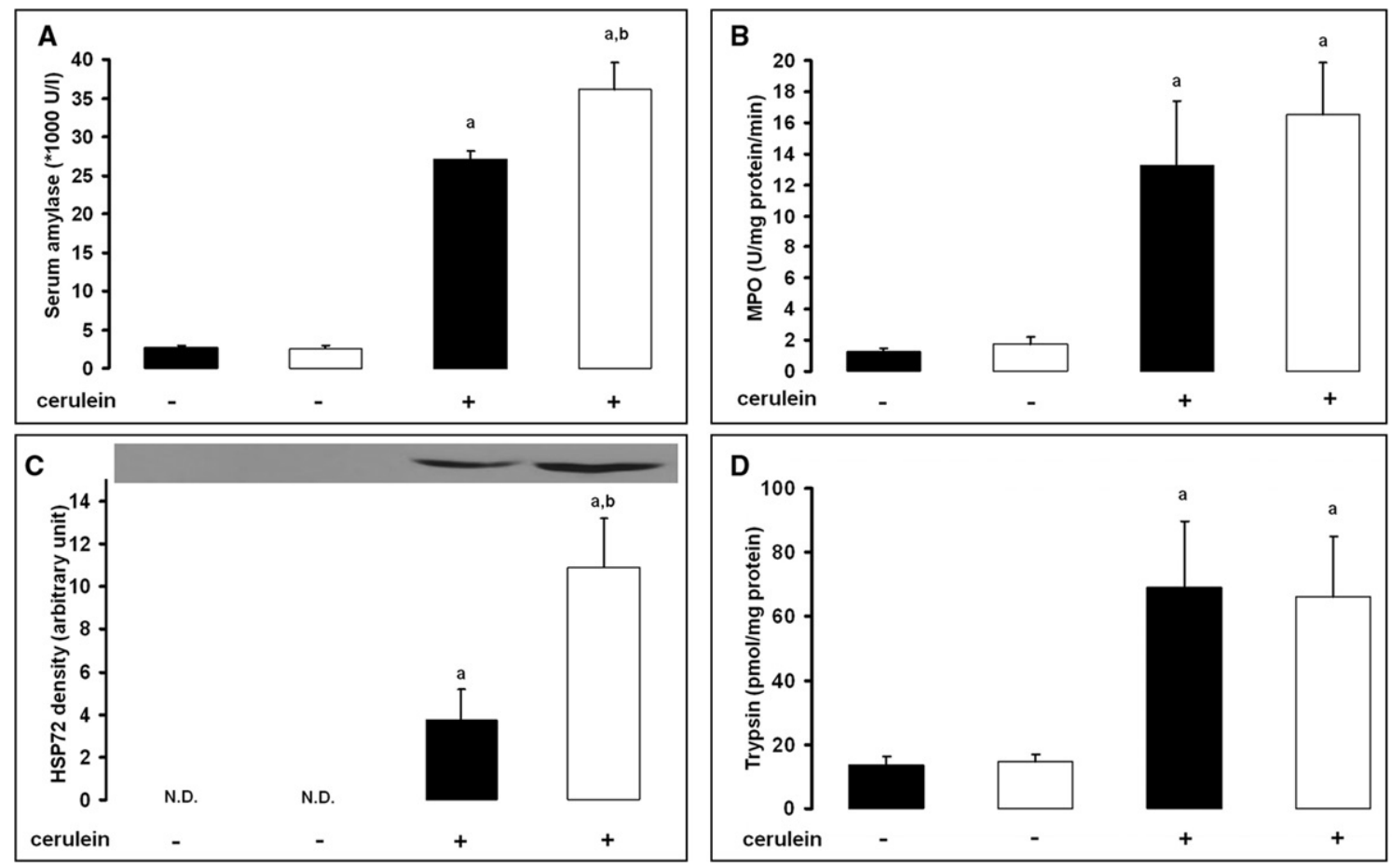

Fig. 6. Severity of cerulein-induced acute pancreatitis and pancreatic trypsinogen activation in wild-type and NHERF-1-knock-out mice. Acute pancreatitis was induced in WT (closed columns) and NHERF-1-KO (open columns) mice by administering $1 \times 50 \mu \mathrm{g} / \mathrm{kg}$ (for measurement of trypsin activity) or 10 hourly i.p. injections 
of $50 \mu \mathrm{g} / \mathrm{kg}$ cerulein (cerulein+). Control mice were given PS (cerulein-) instead of cerulein. Mice were exsanguinated through the inferior vena cava $0.5 \mathrm{~h}$ (in case of measurement of trypsin activity) or $12 \mathrm{~h}$ after the first i.p. injection. The bar diagrams show serum amylase activity (A), the pancreatic myeloperoxidase (MPO) activity (B), heat shock protein-72 (HSP72) expression (C) and trypsin (D) activities. Data are shown as means \pm SEM, $\mathrm{n}=4-6 . \mathrm{P}<0.05$ vs. a: the respective control group or b: vs. the WT cerulein + group. N.D.: not detected. 

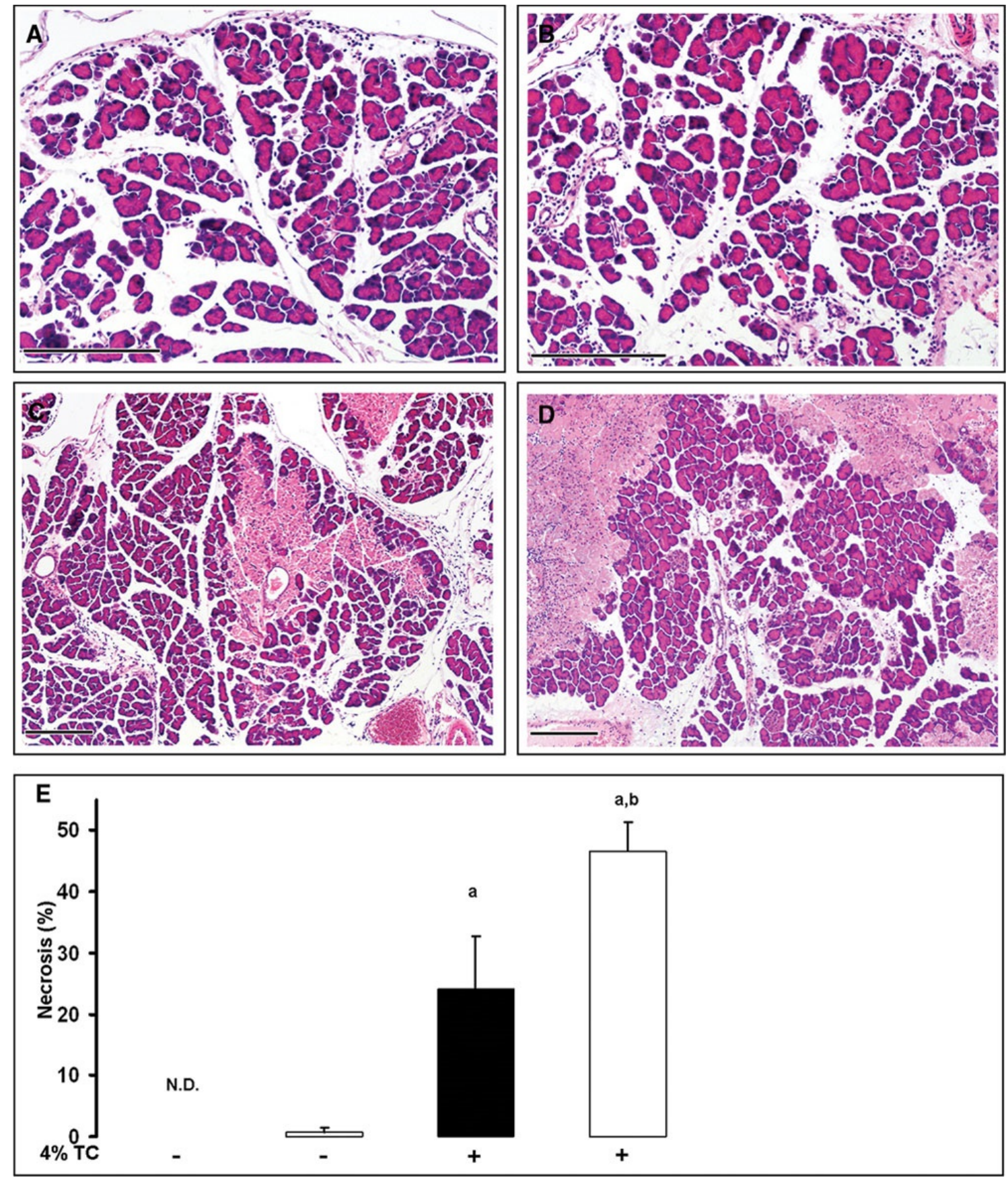

Fig. 7. Histopathologic changes of the pancreatic head in response to intraductal administration of physiological saline and $4 \%$ sodium-taurocholate in wild-type and NHERF-1-knock-out mice. The diagrams show representative light micrographs (H\&E staining) of pancreata of WT (A, C) and NHERF-1-KO (B, D) mice 24 h after intraductal treatment with $50 \mu \mathrm{l}(10 \mu \mathrm{l} / \mathrm{min})$ PS (4\% TC-) (A, B) or $4 \% \mathrm{Na}-$ 
taurocholate $(4 \% \mathrm{TC}+)(\mathbf{C}, \mathbf{D})$. Inflammatory infiltration was significantly higher in NHERF-1-KO (A) vs. WT (B) PS-treated mice. Intraductal infusion with 4\% Nataurocholate caused the development of severe acute necrotizing pancreatitis in WT (C) and NHERF-1-KO (D) mice. The bar diagram shows the rates of pancreatic necrosis $(\mathbf{E})$ in the various groups. Data are shown as means $\pm \mathrm{SEM}, \mathrm{n}=5-7 . \mathrm{P}<0.05$ vs. a: the respective control group or b: vs. the WT 4\%TC+ group. N.D.: not detected in the WT group. Scale bar $=200 \mu \mathrm{m} . \mathrm{WT}$ (closed columns), NHERF-1-KO (open columns).
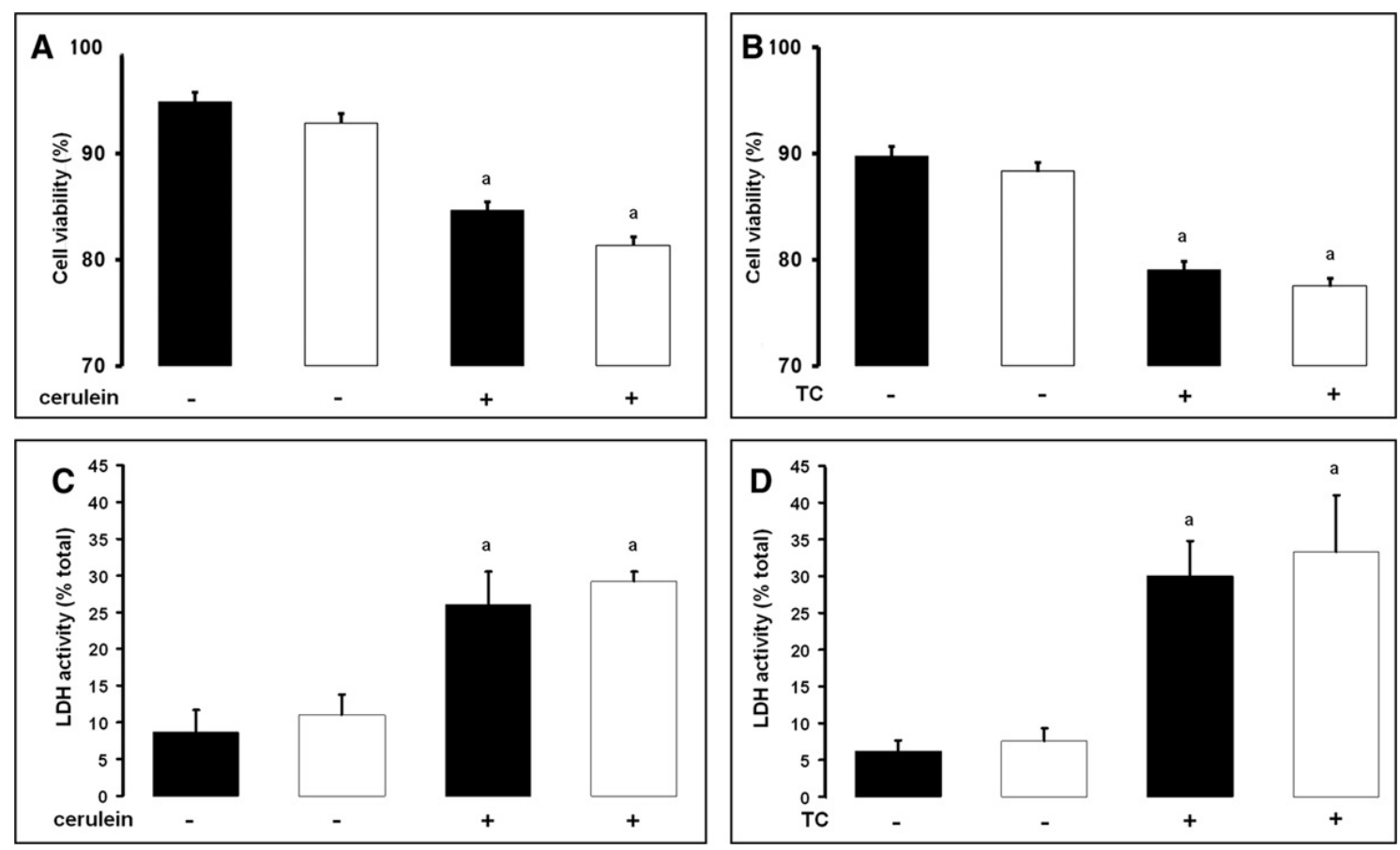

Fig. 8. NHERF-1 expression does not influence the degree of cell damage caused by high concentrations of cerulein or sodium-taurocholate in isolated acinar cells. Acinar cells were isolated from WT and NHERF-1-KO mice by collagenase digestion. In vitro cell damage was induced by the administration of high concentrations of $10^{-8} \mathrm{M}$ cerulein (cerulein + ) for $2 \mathrm{~h}$ or $1 \mathrm{mM} \mathrm{Na-taurocholate}(\mathrm{TC}+)$ for $3 \mathrm{~h}$. Alternatively, cells were treated with the vehicle for cerulein (cerulein-) or Na-taurocholate (TC-) for the 
same time-periods. Cell viability was determined by trypan blue staining $(\mathbf{A}, \mathbf{B})$ and measurement of lactate dehydrogenase $(\mathrm{LDH})$ release $(\mathbf{C}, \mathbf{D})$ from acini. Data are shown as means $\pm \mathrm{SEM}, \mathrm{n}=7 . \mathrm{P}<0.05$ vs. a: the respective control group. WT (closed columns), NHERF-1-KO (open columns). 


\section{TABLES}

\begin{tabular}{|c|c|c|c|c|}
\hline Histologic Features & $\begin{array}{c}\text { WT Physiological } \\
\text { Saline }\end{array}$ & $\begin{array}{c}\text { WT } 4 \% \\
\text { Na-Taurocholate }\end{array}$ & $\begin{array}{c}\text { KO Physiological } \\
\text { Saline }\end{array}$ & $\begin{array}{c}\text { KO 4\% } \\
\text { Na-Taurocholate }\end{array}$ \\
\hline Intestinal edema (0-3) & $1.75 \pm 0.47$ & $2 \pm 0.6$ & $1.8 \pm 0.2$ & $2.35 \pm 0.14$ \\
\hline Hemorrhage (0-3) & 0 & $0.42 \pm 0.2^{\mathrm{a}}$ & 0 & $0.71 \pm 0.28^{a}$ \\
\hline Leukocyte infiltration (0-3) & $0.8 \pm 0.3$ & $1.9 \pm 0.4^{a}$ & $1.6 \pm 0.36^{b}$ & $1.9 \pm 0.45$ \\
\hline
\end{tabular}

Table 1. Histopathological changes in response to intraductal infusion of $4 \%$ sodium-taurocholate and physiological saline in wild-type and NHERF-1-knock-out mice. WT and NHERF-1-KO mice were infused intraductally with 4\% Na-taurocholate or physiological saline (PS, control) and were sacrificed after 24h. Histological scores are shown as means \pm SEM for 5-7 animals. $\mathrm{P}<0.05$ vs. a: the respective PS-treated group or b: vs. the WT PS-treated group. 


\section{SUPPLEMENTARY MATERIALS AND METHODS}

\section{Materials}

All laboratory chemicals were obtained from Sigma-Aldrich (Munich, Germany) unless indicated otherwise. Forskolin was from Tocris Bioscience (Bristol, UK), purified CLSPA collagenase was from Worthington Biochemical Corporation (Lakewood, NJ, USA) and cerulein was from American Peptide Company (Sunnyvale, CA, USA). $\mathrm{H}_{2}$ DIDS, Superscript III RT, TrypLETM Express solution, Alexa Fluor 488-labelled goat anti-rabbit IgG, phalloidin-633 and SlowFade Gold antifade reagent were purchased from Invitrogen Corporation (Carlsbad, CA, USA). CP-Ketamine (10\%) and CP-Xylazine (2\%) were obtained from CP-Pharma-Handelsgesellschaft MBH (Burgdorf, Germany). Urethane was from Reanal (Budapest, Hungary) and pentobarbital was from Bimeda MTC (Cambridge, Canada). DirectPCR (Tail) reagent was obtained from Viagen Biotech Inc. (Los Angeles, CA, USA). NucleoSpin RNA XS Total RNA Isolation Kit was from Machery \& Nagel (Düren, Germany). MesaGreen was from Eurogentec (Seraing, Liège, Belgium). CellTak was purchased from Becton Dickinson Labware (Bedford, Massachusetts, USA). Background reducing buffer was from DAKO (Glostrup, Denmark). Mr Pink rabbit polyclonal antibody against human CFTR provided by W.E. Balch, Scripps Research Institute (La Jolla, CA, USA). An IL-1 $\beta$ ELISA kit was purchased from R\&D Systems (Minneapolis, MN, USA). Laboratory chow was from Biofarm (Zagyvaszántó, Hungary). Dulbecco's Modified Eagle Medium (DMEM) and heat-inactivated fetal bovine serum were purchased from Lonza (Basel, Switzerland). Amylase and lactate dehydrogenase activities were determined using commercial kits (DIALAB GmbH, Neudorf, Austria and Diagnosticum ZRt., Budapest, Hungary, respectively). Isolation of polymorphonuclear cells was performed by Polymorphprep (Axis-Shield, Oslo, Norway). Apoptotic cells were quantitated by using an In Situ Cell Death Detection Kit from Roche Diagnostics (Mannheim, Germany). Concentrated stock solutions of forskolin (100mM), cerulein $(4 \mathrm{mM})$ and amiloride $(50 \mathrm{mM})$ were prepared in dimethylsulfoxide. $2 \%$ stock solution of dextran was dissolved in physiological saline (PS). 


\section{Maintenance and genotyping of mice}

The mice were housed in a standard animal care facility with a 12-h light/12-h dark cycle and were allowed free access to water and standard laboratory chow. Genotyping of mice was performed after DNA extraction from tail samples using the DirectPCR (Tail) reagent supplemented with proteinase $\mathrm{K}$. The primer sequences for genotyping NHERF-1 mice were as follows: wild-type forward, 5'-TCGGGGTTGTTGGCTGGAGAC-3'; common reverse, 5'-AGCCCAACCCGCACTTACCA-3'; KO forward, 5'AGGGCTGGCACTCTGTCG-3'. Amplicons generated by PCR were 294 bp for the WT gene and $242 \mathrm{bp}$ for the $\mathrm{KO}$ gene.

mRNA expression of CFTR, PAT-1, DRA, NHERF-1, NHERF-2 and NHERF-3 in mouse pancreatic ducts

The primer sequences for CFTR Homolog NM_021050 are forward: 5'TTCTTCACGCCCCTATGTCGA-3' reverse: 5'-GCTCCAATCACAATGAACACCA-3' (PCR product length: $145 \mathrm{bp}$ ), for slc26a3 (DRA) NM_021353 are forward: 5'TTCCCCTCAACATCACCATCC-3', reverse: 5'-GTAAAATCGTTCTGAGGCCCC-3' (PCR-product length: 110 bp), for NHERF-2 NM_023449:2 are forward: 5'TAGTCGATCCTGAGACTGATG-3'， reverse: 5'-ATTGTCCTTCTCTGAGCCTG-3' (PCR-product length: $173 \mathrm{bp}$ ), and for NHERF-3 NM_021517:1 are forward: 5'TGACGGTGTGGTGGAAATG-3'， reverse: 5'-TGGCAGTAAAGAAGTGGAGAC-3' (PCR-product length: 117 bp) were designed with "Primer Express" (Applied Biosystems, Foster City, CA, USA). The primers sequences for slc26a6 (putative anion transporter-1, PAT-1) and NHERF-1 were published before [1, 2]. Real-time polymerase chain reactions (qRT-PCR) were carried out using MesaGreen in the Applied Biosystems 7300 Real-time PCR System. PCR extension was performed at $60{ }^{\circ} \mathrm{C}$ with 40 repeats. Data were analyzed using Sequence Detection Software 1.2.3 (Applied Biosystems) and exported to Microsoft Excel. Relative quantification was carried out using $\beta$-actin as a reference gene [3]. 


\section{Immunohistochemistry}

Briefly, for NHERF-1 staining, paraformaldehyde-fixed, paraffin-embedded tissue sections $(5 \mu \mathrm{m})$ from mice of different genotypes were prepared on the same slide. After deparaffinization with xylene, sections were treated with $0.01 \mathrm{M}$ sodium citrate solution at $100{ }^{\circ} \mathrm{C}$ for $10 \mathrm{~min}$. For CFTR staining, pancreata were fixed in $2 \%$ paraformaldehyde (in PBS). Fixed tissue was rinsed with PBS and transferred to 30\% sucrose in PBS overnight. The tissue was embedded in tissue-freezing medium (TissueTec O.C.T., Sakura). Cryosectioning was done with a microtome cryostat at $-20^{\circ} \mathrm{C}$ and $10 \mu \mathrm{m}$ thick sections were collected on microscope slides (SuperFrost Plus, Menzel-Gläser, Germany).

Pancreatic sections were incubated sequentially with PBS for 5 min, washing buffer of PBS with $50 \mathrm{mM} \mathrm{NH}_{4} \mathrm{Cl}$ twice for $10 \mathrm{~min}$ each, background reducing buffer for $20 \mathrm{~min}$ and $5-10 \%$ goat serum for $30 \mathrm{~min}$ for blocking and incubated with rabbit anti-NHERF-1 (1:500) [4] antibody or Mr. Pink rabbit polyclonal antibody against human CFTR (1:100) in background reducing buffer overnight at $4{ }^{\circ} \mathrm{C}$. Washing 4 times for $5 \mathrm{~min}$ in the washing buffer was followed by secondary antibody (Alexa Fluor 488-labelled goat antirabbit $\operatorname{IgG}$ ) incubation for $1 \mathrm{~h}$ at room temperature at a dilution of 1:300-1:500 in background reducing buffer. After 2-4 washes for 5 min each, in case of NHERF-1 staining, the sections were treated with $5 \mathrm{U} / \mathrm{ml}$ phalloidin-633 in PBS with $1 \%$ bovine serum albumin, $0.2 \%$ Triton $\mathrm{X}-100$ for 30 min which was followed by washes with washing buffer (six times). After washing, each cover slide was mounted with SlowFade Gold antifade reagent with DAPI, and slides were imaged on a confocal microscope (TCS SP2; Leica, Wetzlar, Germany). Excitation wavelengths used were 405, 488, and $633 \mathrm{~nm}$, and emission was taken at 415-450, 490-540, and 560-700nm for detection of DAPI, Alexa Fluor 488, and phalloidin 633 , respectively.

\section{Solutions used for the determination of pancreatic ductal $\mathrm{HCO}_{3}^{-}$}


The HEPES-buffered solution contained (in $\mathrm{mM}$ ): $130 \mathrm{NaCl}, 5 \mathrm{KCl}, 1 \mathrm{CaCl}_{2}, 1$ $\mathrm{MgCl}_{2}, 10$ glucose and $10 \mathrm{Na}$-HEPES and its $\mathrm{pH}$ was set to 7.4 with $\mathrm{HCl}$ at $37^{\circ} \mathrm{C}$. The standard $\mathrm{HCO}_{3}{ }^{-}$-buffered solution contained (in $\mathrm{mM}$ ): $115 \mathrm{NaCl}, 25 \mathrm{NaHCO}_{3}, 5 \mathrm{KCl}, 1$ $\mathrm{CaCl}_{2}, 1 \mathrm{MgCl}_{2}, 10$ Glucose. In the $\mathrm{NH}_{4}{ }^{+}$pulse experiments in $\mathrm{HCO}_{3}{ }^{-}$-buffered soultion, $20 \mathrm{mM} \mathrm{NaCl}$ was repleaced with $\mathrm{NH}_{4} \mathrm{Cl}$. The $\mathrm{Cl}^{-}$-free $\mathrm{HCO}_{3}{ }^{-}$solution contained (in $\mathrm{mM}$ ): $25 \mathrm{NaHCO}_{3}, 115 \mathrm{Na}$-gluconate, $1 \mathrm{Mg}$-gluconate, $6 \mathrm{Ca}$-gluconate, $2.5 \mathrm{KH}_{2}$-sulfate and 10 glucose. The $\mathrm{HCO}_{3}{ }^{-}$-containing solutions were equilibrated with $95 \% \mathrm{O}_{2}$ and $5 \% \mathrm{CO}_{2}$ to maintain $\mathrm{pH}$ at 7.4 at $37^{\circ} \mathrm{C}$.

\section{Determination of $\mathrm{HCO}_{3}{ }^{-}$efflux}

To determine the $\mathrm{HCO}_{3}{ }^{-}$efflux across the apical membrane of the pancreatic ductal epithelia, we used three methods: inhibitory stop, alkali load and luminal $\mathrm{Cl}^{-}$withdrawal. The measured rates of $\mathrm{pH}_{\mathrm{i}}$ change $(\mathrm{dpH} / \mathrm{dt})$ were converted to $\mathrm{J}\left(\mathrm{B}^{-}\right)$using the equation: $\mathrm{J}\left(\mathrm{B}^{-}\right)=(\mathrm{dpH} / \mathrm{dt}) \times \beta_{\text {total }}$ where $\beta_{\text {total }}$ is the total buffering capacity of the cells. $\mathrm{J}\left(\mathrm{B}^{-}\right)$reflects the rate of $\mathrm{HCO}_{3}{ }^{-}$efflux (i.e. secretion) on luminal $\mathrm{Cl}^{-} / \mathrm{HCO}_{3}{ }^{-}$exchangers [5].

\section{Measurement of fluid secretion}

In vitro

Fluid secretion into the closed luminal space of the cultured pancreatic ducts was analysed using a swelling method developed by Fernandez-Salazar et al [6]. Briefly, the ducts were transferred to a perfusion chamber $(0.45 \mathrm{ml})$ and were attached to a coverslip precoated with CellTak in the base of the chamber. Bright-field images were acquired at 1 min intervals using a CCD camera (CFW 1308C, Scion Corporation, Frederick, MD, USA). The integrity of the duct wall was checked at the end of each experiment by perfusing the chamber with a hypotonic solution (standard HEPES-buffered solution diluted 1:1 with distilled water). Digital images of the ducts were analysed using Scion Image software 
(Scion Corporation, Frederick, MD, USA) to obtain values for the area corresponding to the luminal space in each image.

In vivo

Mice were anesthetized with $1.5 \mathrm{~g} / \mathrm{kg}$ urethane by i.p. injection. The body temperature of mice was maintained by placing the animals on a warm pad $\left(37^{\circ} \mathrm{C}\right)$ during the experiments. The abdomen was opened, and the lumen of the common biliopancreatic duct was cannulated with a blunt-end 31-gauge needle. Then the proximal end of the common duct was occluded with a microvessel clip to prevent contamination with bile, and the pancreatic juice was collected in PE-10 tube for $30 \mathrm{~min}$. Using an operating microscope, the jugular vein was cannulated for i.v. administration of secretin $(0.75 \mathrm{CU} / \mathrm{kg})$ and the pancreatic juice was collected for an additional $120 \mathrm{~min}$.

\section{Isolation of pancreatic acini}

Mouse pancreatic acinar cells were isolated according to the method of Pandol et al [7]. Briefly, mice were anaesthetized with $85 \mathrm{mg} / \mathrm{kg}$ pentobarbital by i.p. injection. The pancreas was quickly removed, and was cleaned from fat and lymph nodes. The extracellular solution for cell isolation contained (in $\mathrm{mM}$ ) $120 \mathrm{NaCl}, 5 \mathrm{KCl}, 25 \mathrm{HEPES}, 2$ $\mathrm{NaH}_{2} \mathrm{PO}_{4}, 2 \mathrm{CaCl}_{2}, 1 \mathrm{MgCl}_{2}, 5$ pyruvate, 4 Na-fumarate, 4 Na-glutamate, $12 \mathrm{mM}$ Dglucose, as well as $0.02 \%$ (wt/vol) soybean trypsin inhibitor, $0.2 \%(\mathrm{wt} / \mathrm{vol})$ bovine serum albumin, $0.025 \%$ (vol/vol) minimal essential amino acids and $0.01 \%$ (vol/vol) vitamins eagle. The pancreas was inflated with $5 \mathrm{ml}$ of extracellular solution containing collagenase (105 U/ml) then subjected to three successive 20-min incubations in this solution with vigorous shaking at $37{ }^{\circ} \mathrm{C}$. For each 20 -min incubation, the extracellular solution containing collagenase was replaced with a fresh oxygenated aliquot. Acinar cells were then washed three times with extracellular solution, followed by resuspension in Medium 199 and incubated for $30 \mathrm{~min}$. Acinar cells were used for experiments thereafter. Cells were incubated with cerulein $\left(10^{-8}-10^{-12} \mathrm{M}\right), 1 \mathrm{mM} \mathrm{Na}^{+}$-taurocholate or physiological saline. Amylase secretion was determined in response to cerulein and is given as the percentage of total amylase content. The extent of cytotoxicity (in response to $10^{-8} \mathrm{M}$ cerulein and 1 
$\mathrm{mM} \mathrm{Na}^{+}$-taurocholate) as quantified by trypan-blue staining and by measuring the amount of lactate dehydrogenase (LDH) released into the incubation medium of acinar cells. LDH activity was measured spectrophotometrically as the production of NAD from pyruvic acid and NADH. Values for LDH release are presented as the percentage of total LDH activity (medium/medium+cells).

\section{Isolation of polymorphonuclear cells and bacterial killing assay}

Mouse polymorphonuclear cells (PMNs) were isolated from freshly drawn, heparinized blood using Polymorphprep (Axis-Shield) according to the manufacturer's instructions. Isolated PMNs were immadiately plated in round-bottom 96-well plastic cell culture plates $\left(10^{5} \mathrm{PMNs} /\right.$ well $)$ in DMEM supplemented with $10 \%$ autologous serum. $E$. coli bacteria were added to the cultures at an effector/target ratio of 1:5. As a control, the same number of bacterial cells were incubated in the appropriate cell culture medium without PMNs. After a $1 \mathrm{~h}$ incubation period, PMNs were treated with distilled water and the lysates were plated on LB agar plates and incubated overnight at $37{ }^{\circ} \mathrm{C}$. Then, the number of colony forming units was determined and the efficiency of killing was calculated as follows: (number of live E. coli cells in control wells - number of live E. coli cells in cocultures) / number of live E. coli cells in control wells x 100.

\section{Culturing and FITC labeling of $E$. coli bacteria}

E. coli (ATCC 25922) bacteria were grown overnight in LB medium ( $1 \% \mathrm{NaCl}, 1 \%$ tryptone, $0.5 \%$ yeast extract). Cells were harvested by centrifugation, washed twice with PBS, counted in a Bürker-chamber and adjusted to the proper concentration used in subsequent experiments. For phagocytosis assay, E. coli were heat-killed (15 min, $\left.100^{\circ} \mathrm{C}\right)$, and incubated in hydrogen carbonate buffer $\left(50 \mathrm{mM} \mathrm{NaHCO}_{3}, 100 \mathrm{mM} \mathrm{NaCl}\right)$ containing $200 \mu \mathrm{g} / \mathrm{ml}$ fluorescein isothiocyanate (FITC). After $1 \mathrm{~h}$ incubation, cells were washed extensively with PBS and adjusted to the proper concentration used in subsequent experiments. 


\section{Isolation of peritoneal macrophages and phagocytosis assay}

Mouse peritoneal macrophages were obtained by lavage [8] and plated in 24-well $\left(8 \times 10^{5}\right.$ cells/well) flat-bottomed plates in DMEM supplemented with $10 \%$ heat-inactivated fetal bovine serum and 1\% 100x penicillin-streptomycin solution. Macrophages were allowed to attach for $2 \mathrm{~h}$, and their medium was replaced therafter.

Macrophages were co-cultured with the FITC-labeled E. coli at a ratio of 1:5 for 1 $\mathrm{h}$ to allow phagocytosis. After the incubation period, the cell culture medium was removed, and macrophages were washed gently with PBS. Subsequently, $500 \mu 1$ TrypLE ${ }^{\text {TM }}$ Express solution was added to the cultures and incubated for $45 \mathrm{~min}$ at $37{ }^{\circ} \mathrm{C}$ in order to detach cells from the bottom of cell culture plates. Macrophages were then gently resuspended to a single cell suspension by pipetting, harvested by centrifugation, resuspended in $400 \mu 1$ PBS and measured on a FACSCalibur instrument (BD Biosciences, San Jose, CA, USA). Experiments were performed in triplicate. Data were analysed using the FlowJo software.

\section{Intravital video microscopy and data analysis}

A separate experimental series was performed to assess the possible consequences of secretin treatment on the microcirculation of the pancreas in mice anaesthetized with 1.5 $\mathrm{g} / \mathrm{kg}$ urethane i.p. ( $\mathrm{n}=3-4$ in each group). Using an operating microscope, the right jugular vein was cannulated (with polyethylene tubing ID: $0.28 \mathrm{~mm}$, OD: $0.61 \mathrm{~mm}$, Smiths Medical International Ltd, Kent, UK) for i.v. administration of secretin and the fluorescence marker used for the intravital microscopic examination. The animals were placed in a supine position on a heating pad to maintain the body temperature between 36 and $37^{\circ} \mathrm{C}$, and a midline laparotomy performed. The majority of the intestines were exteriorized to gain good assess to the pancreas which was carefully placed on a specially designed stage and covered with a microscopic cover slip. The rest of the exteriorized abdominal organs were also covered with Saran wrap to minimize the fluid and heat loss. 
The microcirculation of the pancreas was visualized by intravital fluorescence microscopy (Zeiss Axiotech Vario 100HD microscope, 100 W HBO mercury lamp, Acroplan 20x water immersion objective) using a single i.v. bolus of fluorescein isothiocyanate-labeled dextran (150 kDa; $75 \mu \mathrm{l} /$ animal for plasma labeling). The microscopic images were recorded with a charge-coupled device video camera (AVT HORN-BC 12; Aalen, Germany) attached to an S-VHS video recorder (Panasonic AG-MD 830, Budapest, Hungary) and a personal computer. Video images of the microcirculatory network of the pancreatic tail were recorded at baseline and 20 min after the i.v. application of secretin.

Plasma velocity in the pancreatic capillaries was assessed off-line by frame-toframe analysis of the videotaped images, using image analysis software (IVM, Pictron Ltd., Budapest, Hungary). Average velocity values were measured in 3-5 separate capillaries per 3-5 microscopic fields in each animal.

\section{Sodium-taurocholate-induced pancreatitis}

Na-taurocholate was administered intraductally as described previously by Perides et al [9]. Briefly, anesthesia was achieved with a $125 \mathrm{mg} / \mathrm{kg}$ ketamine and $12.5 \mathrm{mg} / \mathrm{kg}$ xylazine cocktail. After median laparotomy, the duodenum was punctured with a $0.4 \mathrm{~mm}$ diameter needle connected to polyethylene tubing. Leakage of Na-taurocholate was prevented by temporary ligature of the biliopancreatic duct, while the proximal bile duct was temporarily occluded with a microvessel clip. 4\% Na-taurocholate or PS solution was infused with an infusion pump (10 $\mu \mathrm{l} / \mathrm{min})$ (TSE System GmbH, Bad Homburg, Germany) for $5 \mathrm{~min}$. After the infusion, the microvessel clip, the injection needle, as well as the distal ligature were removed, and the abdominal wall and the skin were closed separately. Mice were sacrificed $24 \mathrm{~h}$ later.

\section{Sacrifice of animals, sample processing}


Mice were anesthetized with pentobarbital (85 mg/kg i.p.). The animals were exsanguinated through the inferior vena cava and the pancreas was quickly removed, cleaned from fat and lymph nodes and frozen in liquid nitrogen and stored at $-80{ }^{\circ} \mathrm{C}$ until use for assays or put into $6 \%$ neutral formaldehyde solution for histologic examinations. In case of taurocholate-induced pancreatitis, the pancreas was removed with attached duodenum and spleen for histologic examinations. Only the pancreatic head was used for laboratory measurements. The pancreatic head (defined as the portion of the pancreas located within $5 \mathrm{~mm}$ of the lesser duodenal curvature) was separated from the pancreatic body/tail regions.

The pancreas fixed in $6 \%$ neutral formaldehyde solution was subsequently embedded in paraffin. Sections were cut at $4 \mu \mathrm{m}$ thickness and stained with hematoxylin and eosin. The slides were coded and read by two independent observers who were blind to the experimental protocol. In case of taurocholate-induced pancreatitis only the pancreatic head (defined as the portion of the pancreas located within $\sim 5 \mathrm{~mm}$ of the lesser duodenal curvature) was investigated. The observers investigated 4-6 low-power fields in the head of the pancreas. 


\section{SUPPLEMENTARY FIGURES}

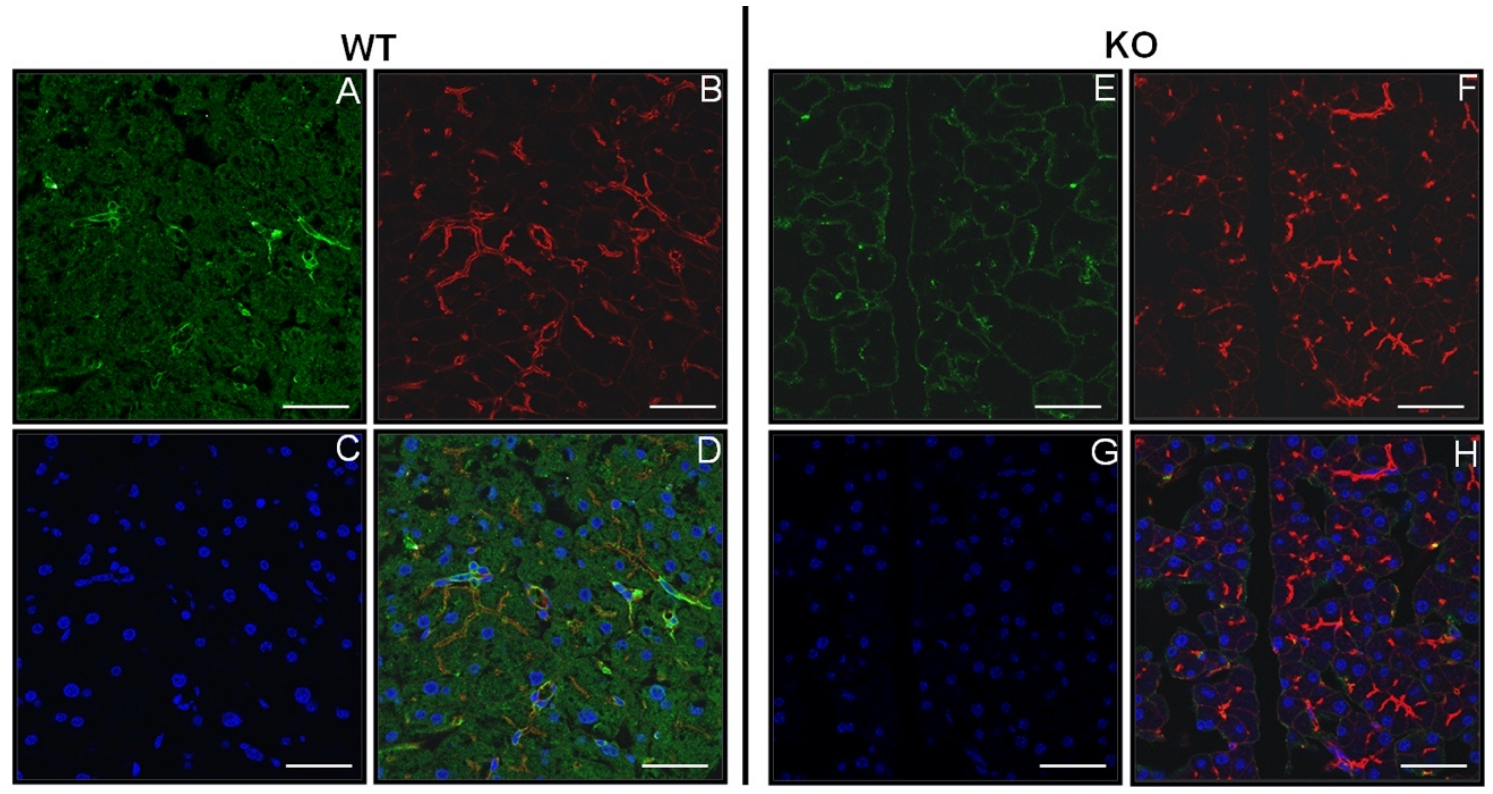

Supplementary figure 1. Specificity of Mr Pink rabbit polyclonal CFTR antibody tested in the pancreas of CFTR-knock-out mouse. Representative immunohistochemical stainings in the pancreas of WT (A-D) and CFTR-KO (E-H) mice. KO mice showed no apical-specific staining of CFTR (green) in the KO (E) vs. the WT (A) tissue. Red color indicates the staining of F-actin $(\mathbf{B}, \mathbf{F})$. The nuclei are stained with DAPI (blue) (C, G). D and $\mathbf{H}$ show merged images of CFTR, F-actin and nucleus. Scale bar $=50 \mu \mathrm{m}$. 


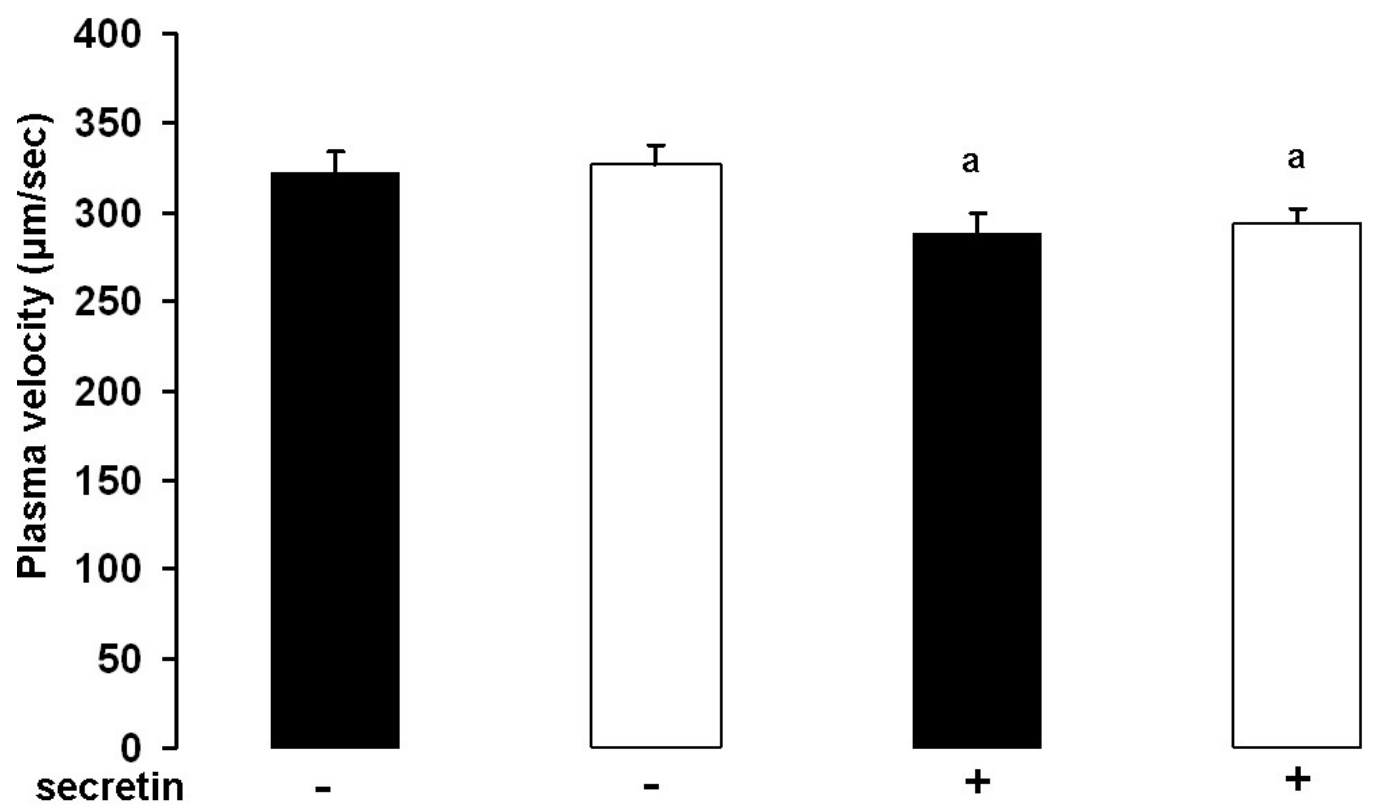

Supplementary figure 2. Pancreatic microcirculation shows similar changes in wild-type and NHERF-1-knock-out mice. The microcirculation of the pancreatic tail was visualized by intravital fluorescence microscopy (see supplementary methods) using a single i.v. bolus of fluorescein isothiocyanate-labelled dextran for plasma labeling in wildtype (closed columns) or NHERF-1-KO (open columns) mice anesthetized with urethane ( $1.5 \mathrm{~g} / \mathrm{kg}$ i.p.). Video images were recorded at baseline (secretin -) and $20 \mathrm{~min}$ after the i.v. administration of secretin $(0.75 \mathrm{CU} / \mathrm{kg}$, secretin +$)$. 20min after the i.v. injection of secretin, significantly lower plasma velocity values were observed in both experimental groups. These reduced microcirculatory velocities, however, were not due to the effect of secretin, but most likely resulted from the 20-min exteriorization period of the pancreas, since a similar degree of reduction (by about 10\%) in plasma velocities was also observed in timematched pilot studies where mice were treated with PS vehicle (data not shown). a: $\mathrm{P}<0.05$ vs. the respective secretin - group. 


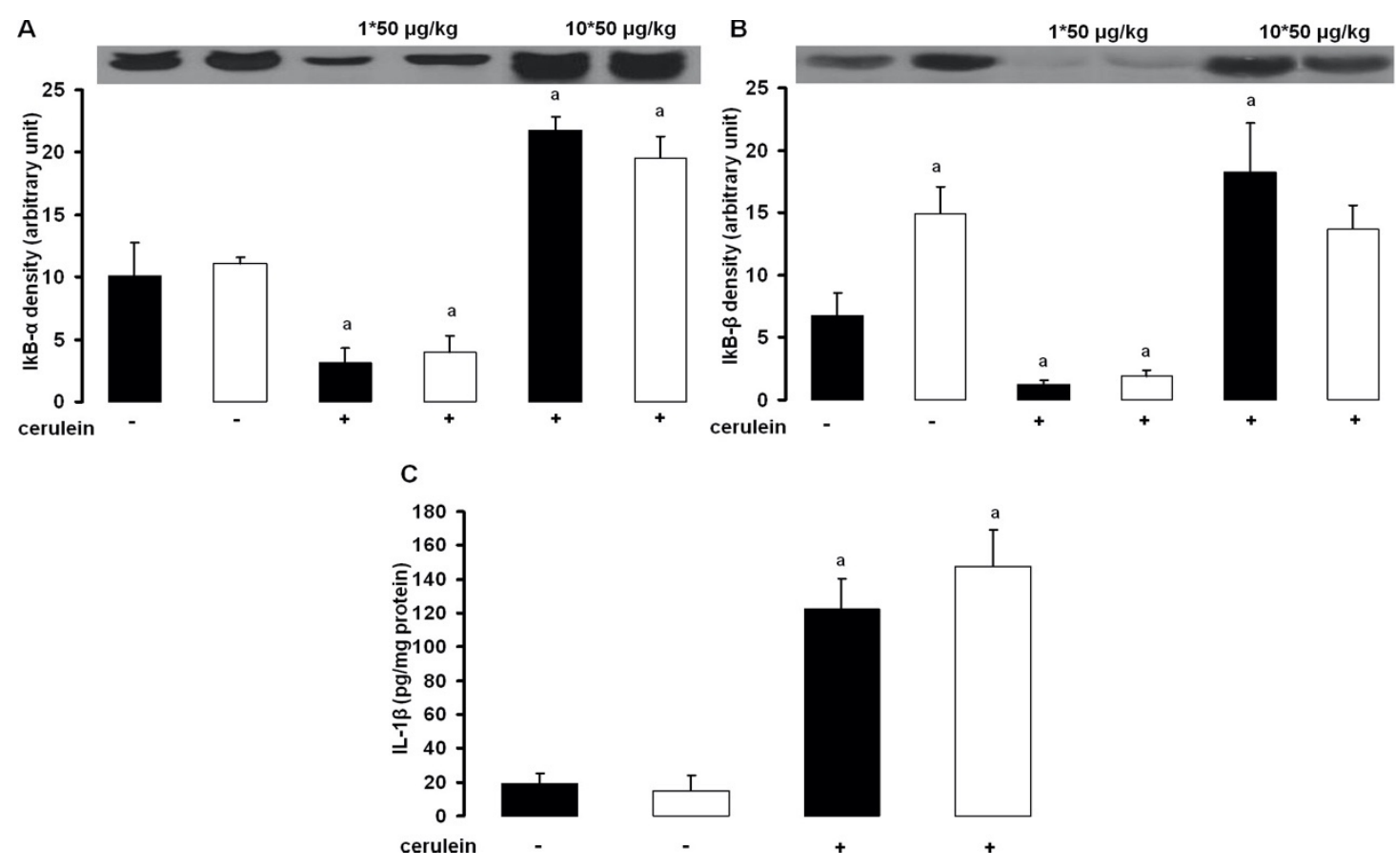

Supplementary figure 3. Effects of cerulein administration on pancreatic IкB$\alpha$, IкB- $\beta$, interleukin-1 $\beta$ in wild-type and NHERF-1-knock-out mice. Acute pancreatitis

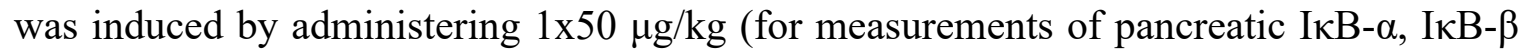
levels) or 10 hourly (A-C) i.p. injection of $50 \mu \mathrm{g} / \mathrm{kg}$ cerulein (cerulein+) in WT (closed columns) and NHERF-1-KO (open columns) mice. Control animals were given PS (cerulein-) instead of cerulein. Mice were sacrificed by exsanguination through the inferior vena cava $0.5 \mathrm{~h}$ (in case of administration of $1 \times 50 \mu \mathrm{g} / \mathrm{kg}$ cerulein) or $12 \mathrm{~h}$ after the first i.p. injection. The bar diagrams and the representative Western immunoblot analysis $(\mathbf{A}, \mathbf{B})$ of

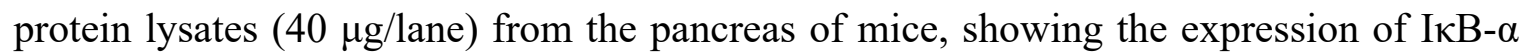
(A) and I $\mathrm{I} B-\beta$ (B). Equal loading/transfer of proteins was checked by Ponceau S staining of the nitrocellulose membrane. IL-1 $\beta$ expression (C) was determined from the pancreatic homogenates by ELISA. Means \pm SEM for 4-6 animals are shown. $\mathrm{P}<0.05$ vs. a: the respective control group or b: vs. the WT cerulein+ group. N.D.: not detected. 
A

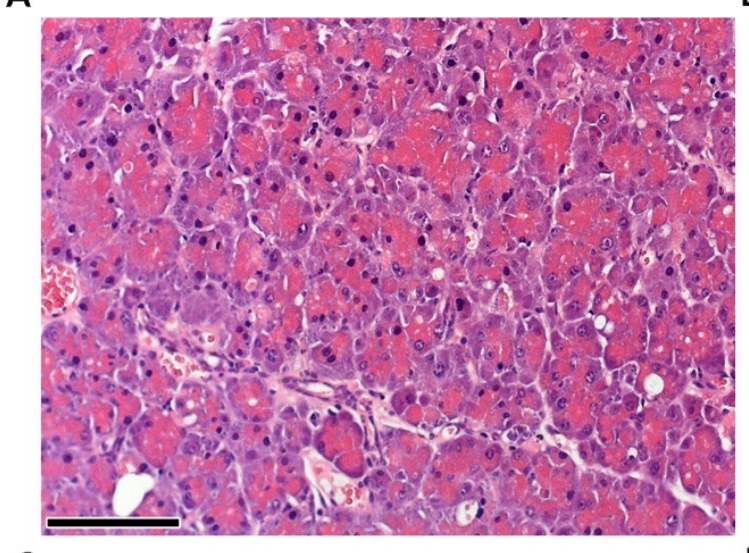

C

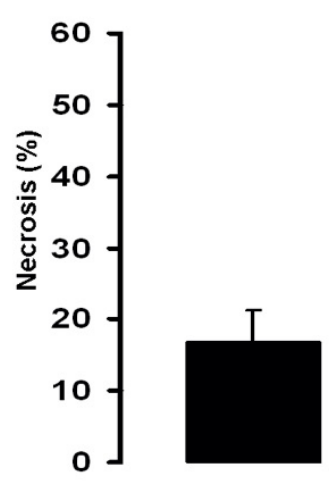

B

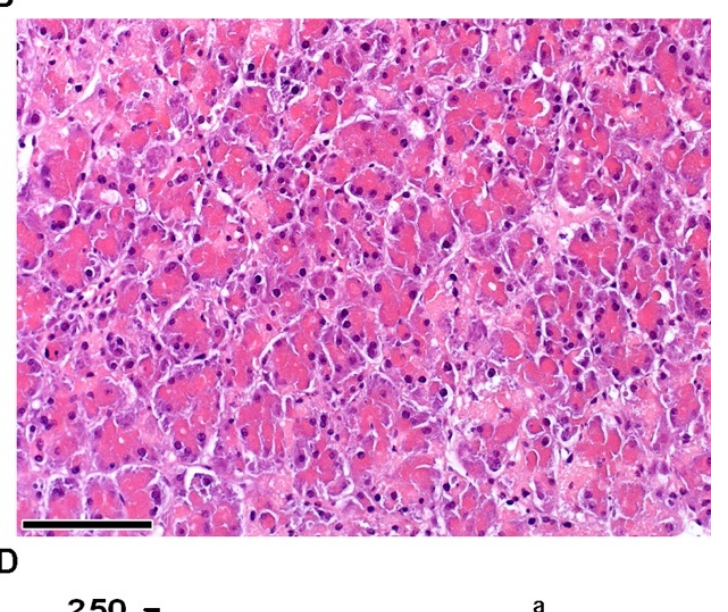

Supplementary figure 4. Histopathologic changes of the pancreas in response to intraperitoneal administration of cerulein in wild-type and NHERF-1-knock-out mice. Acute pancreatitis was induced in WT (closed columns) and NHERF-1-KO (open columns) mice by administering 7 hourly i.p. injections of cerulein $(50 \mu \mathrm{g} / \mathrm{kg}$ per injection). The mice were sacrificed by exsanguination through the inferior vena cava $12 \mathrm{~h}$ after the first i.p. injection. The diagrams show representative light micrographs (hematoxylin and eosin staining) of the pancreata of cerulein-treated WT (A) and NHERF-1-KO (B) mice. The bar diagrams show the rates of pancreatic necrosis $(\mathbf{C})(n=8)$ and apoptosis $(\mathbf{D})(n=4)$. Data are shown as means \pm SEM. a: $\mathrm{P}<0.05$ vs. the WT group. Scale bar $=100 \mu \mathrm{m}$. 
A

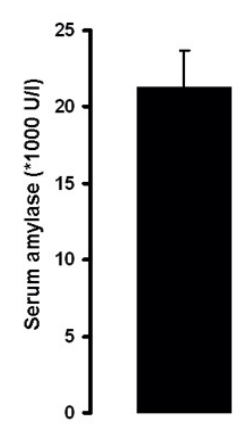

D

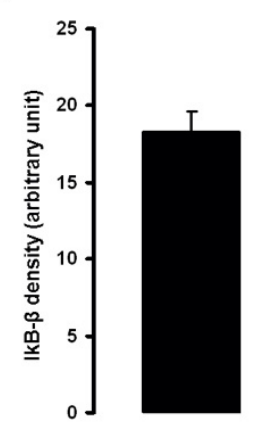

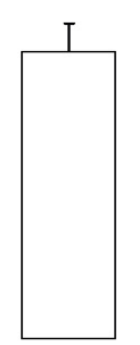

B

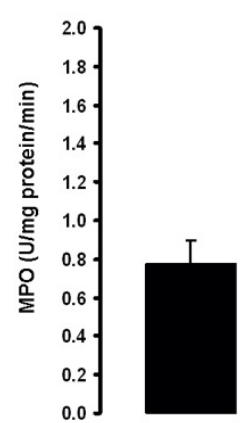

E

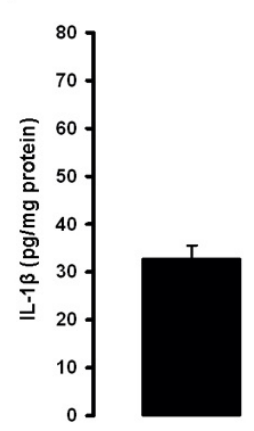

C
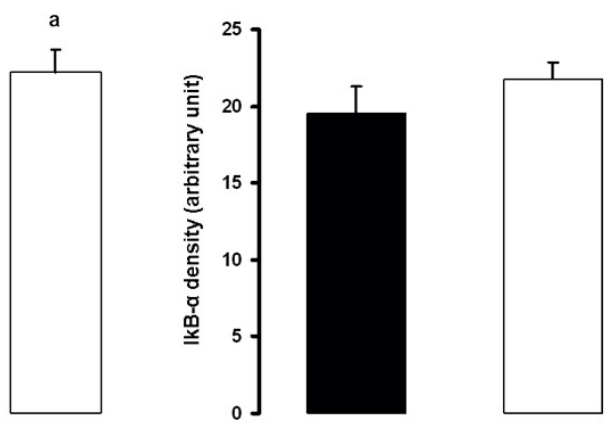

$\mathbf{F}$

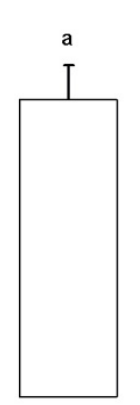

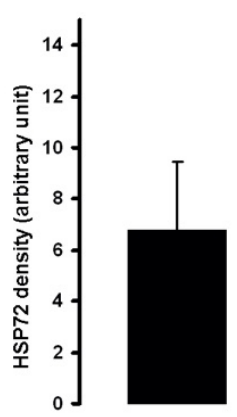

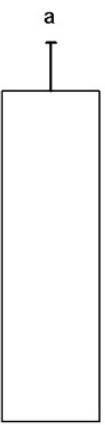

Supplementary figure 5. Severity of cerulein-induced acute pancreatitis in wild-type and NHERF-1-knock-out mice. Acute pancreatitis was induced in WT (closed columns) and NHERF-1-KO (open columns) mice by administering 7 hourly i.p. injections of $50 \mu \mathrm{g} / \mathrm{kg}$ cerulein. The mice were sacrificed by exsanguination through the inferior vena cava $12 \mathrm{~h}$ after the first i.p. injection. There was no significant difference in serum amylase activity of WT and NHERF-1-KO mice (A). Pancreatic MPO activity was significantly increased in NHERF-1-KO vs. WT mice (B). No significant difference was detected between WT and NHERF-1-KO mice in expression of pancreatic I $\mathrm{KB}-\alpha(\mathbf{C})$. The expression of pancreatic IкB- $\beta$ was significantly lower in NHERF-1-KO vs. WT mice (D). The expression of pancreatic IL-1 $\beta$ (E) and HSP72 (F) were significantly higher in NHERF-1-KO vs. WT animals. Data are shown as means \pm SEM, $n=4-6$. a: $P<0.05$ vs. the respective control group. 


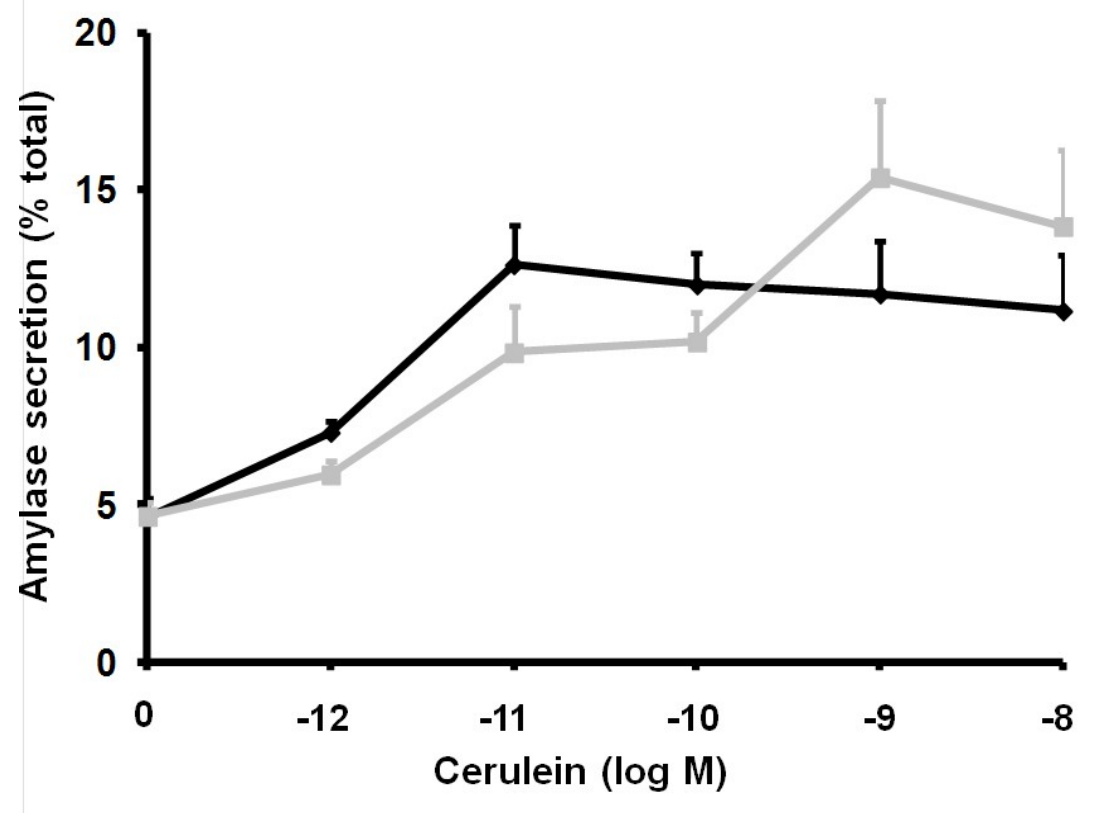

Supplementary figure 6. Acinar sensitivity to cerulein is unaltered by NHERF-

1 expression. To determine the sensitivity of dispersed acinar cells (see supplementary methods) of WT (black line) and NHERF-1-KO (grey line) mice to cerulein, amylase secretion was determined in response to various concentrations $\left(10^{-12}-10^{-8} \mathrm{M}\right)$ of cerulein for $30 \mathrm{~min}$. Amylase secretion was calculated as the percent of total release (medium/medium+cells). a: $\mathrm{P}<0.05$ vs. $0 \mathrm{M}$ cerulein, $\mathrm{n}=4-6$ animals. 
A

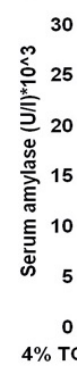

$\left.\begin{array}{l}30 \\ 25 \\ 20 \\ 15 \\ 10 \\ 5 \\ 0 \\ 0 \\ \text { TC }\end{array}\right]$

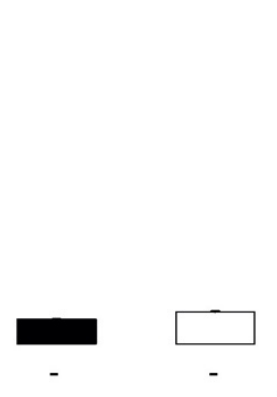

$\mathrm{C}_{3}$
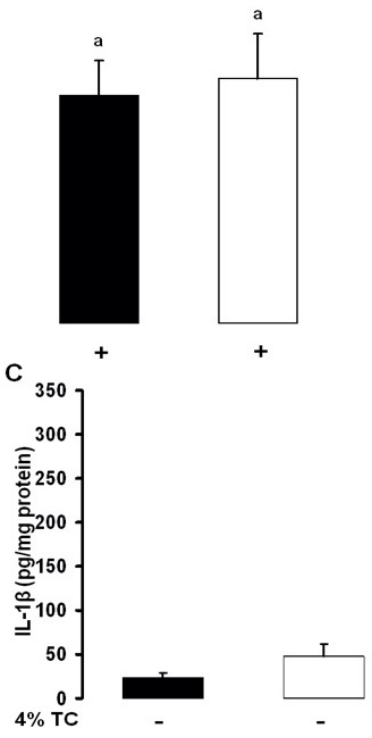

B

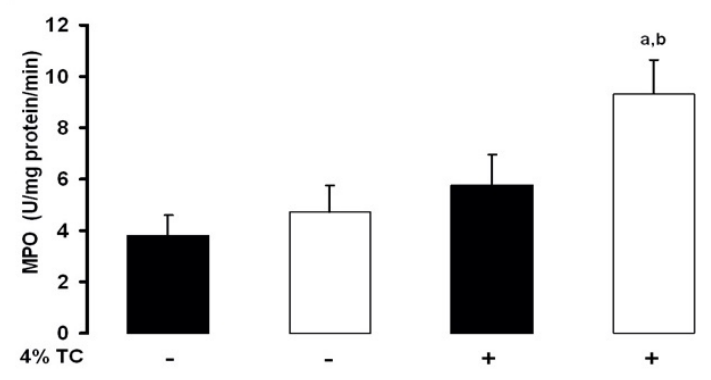

Supplementary figure 7. Severity of sodium-taurocholate-induced acute pancreatitis in wild-type and NHERF-1-knock-out mice. WT and NHERF-1-KO mice were treated as described in Figure 8 . The mice were sacrificed by exsanguination through the inferior vena cava $24 \mathrm{~h}$ after the infusion. There were no significant differences in serum amylase (A) and pancreatic MPO (B) activities between $\mathrm{Na}^{+}$-taurocholate-treated WT (closed columns) and NHERF-1-KO (open columns) mice. There was no significant difference in the levels of pancreatic IL-1 $\beta$ (C) of $\mathrm{Na}^{+}$-taurocholate-treated WT and NHERF-1-KO mice. Data are shown as means \pm SEM, $\mathrm{n}=4-6 . \mathrm{P}<0.05$ vs. a: the respective control group or b: vs. the WT 4\% TC+ group. 
A

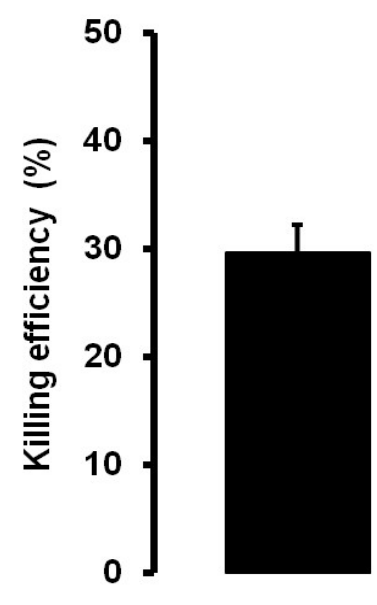

B

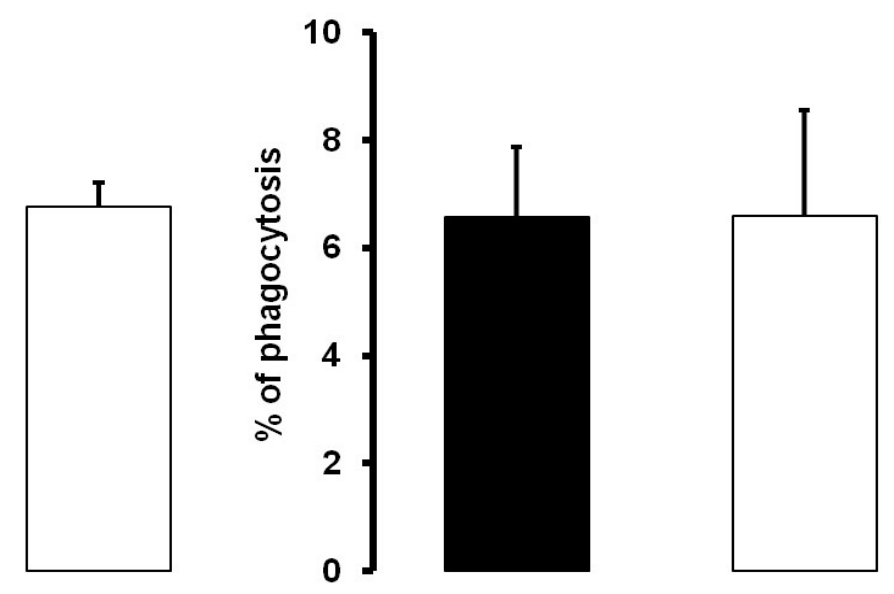

Supplementary figure 8. Functions of inflammatory cells are unaltered by deletion of NHERF-1. Blood polymorphonuclear cells and peritoneal macrophages were isolated from WT and NHERF-1-KO mice. (A) Bacterial killing efficiency of polymorphonuclear cells (PMNs) after a $1 \mathrm{~h}$ incubation period with E. coli was deduced from the number of colony forming units from control wells (without PMNs) and cocultured wells (containing PMNs). (B) Phagocytosis by macrophages was determined on FITC-labeled, heat-killed E. coli. Data are shown as means \pm SEM. WT (closed columns), NHERF-1-KO (open columns). 
A

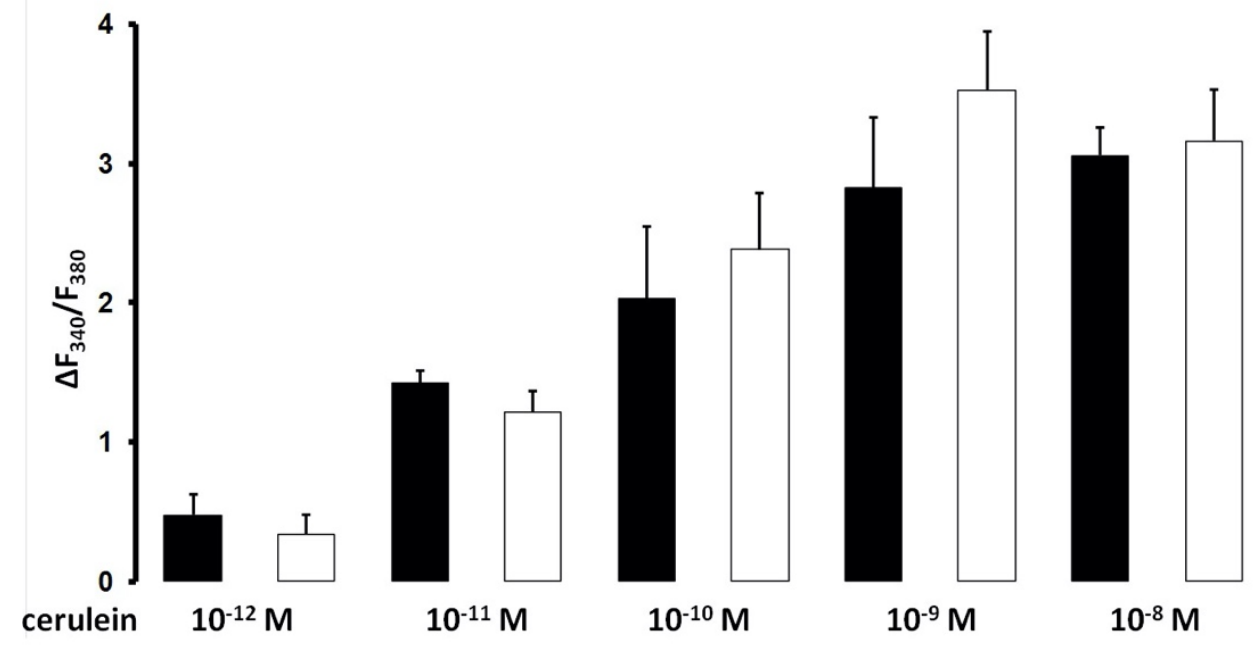

B

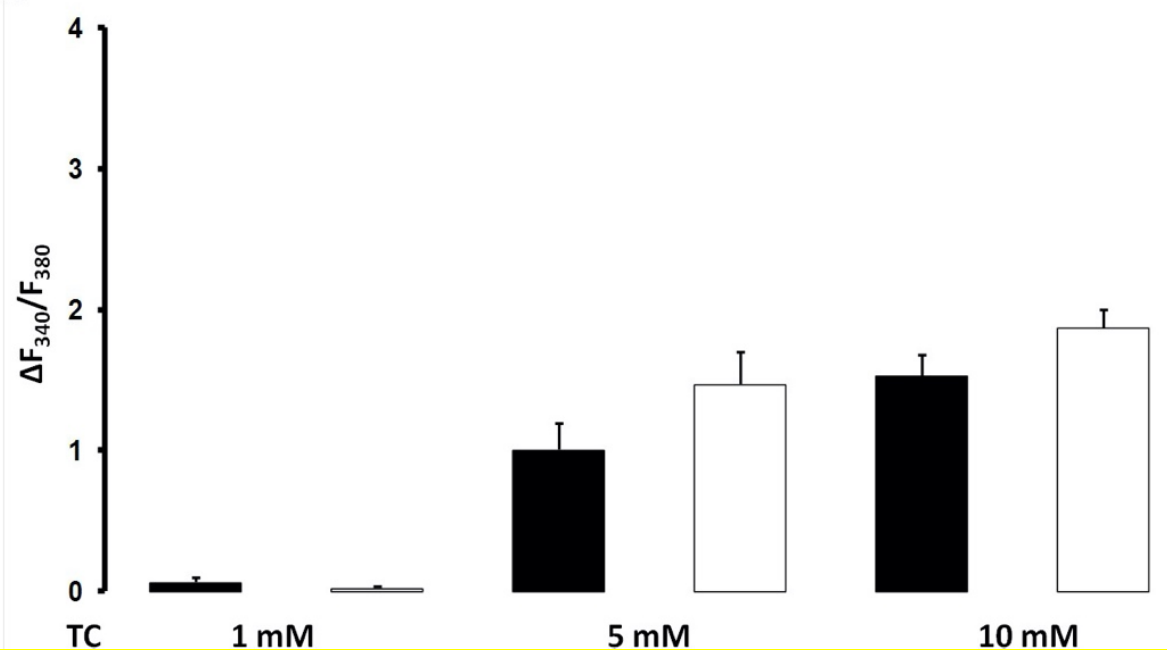

Supplementary figure 9. NHERF-1 expression does not influence the changes in intracellular $\mathrm{Ca}^{2+}$ concentration caused by cerulein or sodium-taurocholate in isolated acinar cells. Acinar cells were isolated from WT and NHERF-1-KO mice by collagenase digestion. Summary data show the maximal changes of $\left[\mathrm{Ca}^{2+}\right]_{\mathrm{i}}$ induced by administration of cerulein or $\mathrm{Na}^{+}$-taurocholate (TC). There were no significant differences between WT and NHERF-1 KO mice in the changes of $\left[\mathrm{Ca}^{2+}\right]_{i}$ on isolated acinar cell in response to different concentrations of cerulein $\left(10^{-8}-10^{-12} \mathrm{M}\right)(\mathbf{A})$ or TC $(1-10 \mathrm{mM})(\mathbf{B})$. Data are shown as means \pm SEM, $n=5-8$. WT (closed columns), NHERF-1-KO (open columns). 


\section{SUPPLEMENTARY REFERENCES}

1. Alvarez BV, Kieller DM, Quon AL, Markovich D, Casey JR: Slc26a6: a cardiac chloride-hydroxyl exchanger and predominant chloride-bicarbonate exchanger of the mouse heart. $J$ Physiol 2004, 561:721-734.

2. Hillesheim J, Riederer B, Tuo B, Chen M, Manns M, Biber J, Yun C, Kocher O, Seidler U: Down regulation of small intestinal ion transport in PDZK1(CAP70/NHERF3) deficient mice. Pflugers Arch 2007, 454(4):575-586.

3. Giulietti A, Overbergh L, Valckx D, Decallonne B, Bouillon R, Mathieu C: An overview of real-time quantitative PCR: applications to quantify cytokine gene expression. Methods 2001, 25(4):386-401.

4. Weinman EJ, Steplock D, Tate K, Hall RA, Spurney RF, Shenolikar S: Structurefunction of recombinant $\mathrm{Na} / \mathrm{H}$ exchanger regulatory factor (NHE-RF). $J$ Clin Invest 1998, 101(10):2199-2206.

5. Hegyi P, Rakonczay Z, Jr., Tiszlavicz L, Varró A, Tóth A, Rácz G, Varga G, Gray $\mathrm{MA}$, Argent BE: Protein kinase $\mathrm{C}$ mediates the inhibitory effect of substance $\mathrm{P}$ on $\mathrm{HCO}_{3}{ }^{-}$secretion from guinea pig pancreatic ducts. Am J Physiol Cell Physiol 2005, 288(5):C1030-1041.

6. Fernandez-Salazar MP, Pascua P, Calvo JJ, Lopez MA, Case RM, Steward MC, San Roman JI: Basolateral anion transport mechanisms underlying fluid secretion by mouse, rat and guinea-pig pancreatic ducts. $J$ Physiol 2004, 556(Pt 2):415-428.

7. Pandol SJ, Jensen RT, Gardner JD: Mechanism of [Tyr4]bombesin-induced desensitization in dispersed acini from guinea pig pancreas. J Biol Chem 1982, 257(20):12024-12029.

8. Zhang X, Goncalves R, Mosser DM: The isolation and characterization of murine macrophages. Current protocols in immunology / edited by John E Coligan [et al] 2008, Chapter 14:Unit 1411.

9. Perides G, van Acker GJ, Laukkarinen JM, Steer ML: Experimental acute biliary pancreatitis induced by retrograde infusion of bile acids into the mouse pancreatic duct. Nat Protoc 2010, 5(2):335-341. 


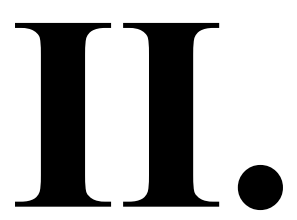


OPEN ACCESS

Edited by: Alexei Tepikin University of Liverpoo, United Kingdom

Reviewed by: Julia Gerasimenko, Cardiff University, United Kingdom Jason I. E. Bruce, University of Manchester, United Kingdom

*Correspondence:

Péter Hegyi hegyi.peter@pte.hu

Specialty section This article was submitted to Gastrointestinal Sciences, a section of the journal Frontiers in Physiology

Received: 21 April 2018 Accepted: 15 June 2018 Published: 12 July 2018

Citation:

Venglovecz V, Pallagi P, Kemény LV Balázs A, Balla Z, Becskeházi E, Gál E, Tóth E, Zvara Á, Puskás LG, Borka K, Sendler M, Lerch MM, Mayerle J, Kühn J-P, Rakonczay Z Jr. and Hegyi P (2018) The Importance of Aquaporin 1 in Pancreatitis and lts Relation to the CFTR Cl- Channel. Front. Physiol. 9:854. doi: 10.3389/fphys.2018.00854

\section{The Importance of Aquaporin 1 in Pancreatitis and Its Relation to the CFTR $\mathrm{Cl}^{-}$Channel}

Viktória Venglovecz ${ }^{1}$, Petra Pallagi ${ }^{2}$, Lajos V. Kemény ${ }^{1}$, Anita Balázs ${ }^{2}$, Zsolt Balla ${ }^{3}$, Eszter Becskeházi ${ }^{1}$, Eleonóra Gál' ${ }^{1}$, Emese Tóth², Ágnes Zvara ${ }^{4}$, László G. Puskás ${ }^{4}$, Katalin Borka ${ }^{5}$, Matthias Sendler ${ }^{6}$, Markus M. Lerch ${ }^{6}$, Julia Mayerle ${ }^{6,7}$, Jens-Peter Kühn ${ }^{8,9}$, Zoltán Rakonczay $\mathrm{Jr}^{3}$ and Péter Hegyi ${ }^{2,10,11 *}$

${ }^{1}$ Department of Pharmacology and Pharmacotherapy, University of Szeged, Szeged, Hungary, ${ }^{2}$ First Department of Medicine, University of Szeged, Szeged, Hungary, ${ }^{3}$ Department of Pathophysiology, University of Szeged, Szeged, Hungary, ${ }^{4}$ Laboratory of Functional Genomics, Biological Research Centre, Hungarian Academy of Sciences, Szeged, Hungary, ${ }^{5}$ Second Department of Pathology, Semmelweis University, Budapest, Hungary, ${ }^{6}$ Department of Medicine A, University Medicine Greifswald, University of Greifswald, Greifswald, Germany, ${ }^{7}$ Department of Medicine II, Klinikum Grosshadern, Universitätsklinikum der Ludwig-Maximilians-Universität München, Munich, Germany, ${ }^{8}$ Institute of Radiology, University Medicine Greifswald, University of Greifswald, Greifswald, Germany, ${ }^{9}$ Institute and Policlinic of Radiology, University Hospital Carl Gustav Carus, TU Dresden, Dresden, Germany, ${ }^{10}$ MTA-SZTE Translational Gastroenterology Research Group, University of Szeged, Szeged, Hungary, " Institute for Translational Medicine and First Department of Medicine, Medical School, University of Pécs, Pécs, Hungary

Aquaporins (AQPS) facilitate the transepithelial water flow involved in epithelial fluid secretion in numerous tissues; however, their function in the pancreas is less characterized. Acute pancreatitis (AP) is a serious disorder in which specific treatment is still not possible. Accumulating evidence indicate that decreased pancreatic ductal fluid secretion plays an essential role in AP; therefore, the aim of this study was to investigate the physiological and pathophysiological role of AQPs in the pancreas. Expression and localization of AQPs were investigated by real-time PCR and immunocytochemistry, whereas osmotic transmembrane water permeability was estimated by the dye dilution technique, in Capan-1 cells. The presence of AQP1 and CFTR in the mice and human pancreas were investigated by immunohistochemistry. Pancreatic ductal $\mathrm{HCO}_{3}{ }^{-}$and fluid secretion were studied on pancreatic ducts isolated from wild-type (WT) and AQP1 knock out (KO) mice using microfluorometry and videomicroscopy, respectively. In vivo pancreatic fluid secretion was estimated by magnetic resonance imaging. AP was induced by intraperitoneal injection of cerulein and disease severity was assessed by measuring biochemical and histological parameters. In the mice, the presence of AQP1 was detected throughout the whole plasma membrane of the ductal cells and its expression highly depends on the presence of CFTR Cl- channel. In contrast, the expression of AQP1 is mainly localized to the apical membrane of ductal cells in the human pancreas. Bile acid treatment dose- and time-dependently decreased mRNA and protein expression of AQP1 and reduced expression of this channel was also demonstrated in patients suffering from acute and chronic pancreatitis. $\mathrm{HCO}_{3}{ }^{-}$and fluid secretion significantly decreased in AQP1 KO versus WT mice and the absence of 
AQP1 also worsened the severity of pancreatitis. Our results suggest that AQP1 plays an essential role in pancreatic ductal fluid and $\mathrm{HCO}_{3}{ }^{-}$secretion and decreased expression of the channel alters fluid secretion which probably contribute to increased susceptibility of the pancreas to inflammation.

Keywords: pancreas, aquaporins, bile acids, $\mathrm{HCO}_{3}{ }^{-}$secretion, $\mathrm{CFTR} \mathrm{Cl}^{-}$channel

\section{INTRODUCTION}

The pancreas secretes 1.5-2 1 of fluid per day (Hegyi et al., 2011a; Pallagi et al., 2015). This fluid contains the inactive form of digestive enzymes and is prominently rich in $\mathrm{HCO}_{3}{ }^{-}$ produced by the ductal cells (Pallagi et al., 2015). The main functions of this $\mathrm{HCO}_{3}{ }^{-}$-rich fluid are (i) to prevent the premature activation of zymogens (Pallagi et al., 2011), (ii) to wash out the toxic factors (such as bile acids) from the ductal tree (Venglovecz et al., 2008), and (iii) to provide an alkaline environment in the duodenum for the optimal function of digestive enzymes (Steward et al., 2005). In the last few years, the importance of ion transport proteins has been highlighted in the course of pancreatitis; therefore intensive research has been conducted in order to characterize their pathological roles (Hegyi and Rakonczay, 2015; Pallagi et al., 2015). These clinical and experimental studies indicate that impaired ductal $\mathrm{HCO}_{3}{ }^{-}$ secretion makes the pancreas more susceptible to inflammatory diseases such as acute or chronic pancreatitis (CP) (Hegyi and Rakonczay, 2010; Hegyi et al., 2011b; Takacs et al., 2013; Pallagi et al., 2014; Maleth et al., 2015). In contrast, much less is known about the water transport processes, despite the fact that movement of electrolytes is osmotically coupled to water flow.

Aquaporins (AQPs) are small membrane proteins that primarily mediate the transport of water molecules and recent research also emphasize their importance in certain regulatory processes (Rodriguez et al., 2011; Ribatti et al., 2014; Madeira et al., 2015). In mammals, $13 \mathrm{AQP}$ isoforms have been identified so far and a few of them show a species-specific expression pattern in the pancreas. In humans, AQP1, $-5,-8$, and -12 are present in the pancreas (Hurley et al., 2001; Tani et al., 2001; Furuya et al., 2002; Burghardt et al., 2003; Itoh et al., 2005). AQP1 is the first AQP which has been described and is exclusively permeable to water (Preston et al., 1992). The presence of this channel has been shown in the apical and lateral plasma membrane of centroacinar cells, and in the apical and basolateral membranes of intercalated and intralobular ducts (Furuya et al., 2002; Burghardt et al., 2003). AQP5 is an aquaglyceroporin which mediates the transport of glycerol, urea and other small solutes beside water. Expression of AQP5 has only been detected in the apical plasma membrane of intercalated ducts but not in the centroacinar cells (Burghardt et al., 2003). AQP1 and -5 are colocalized with the cystic fibrosis transmembrane conductance regulator (CFTR) $\mathrm{Cl}^{-}$channel at the apical membrane of the ductal cells which indicates that these channels influence each other's function (Burghardt et al., 2003). AQP8 and 12 are exclusively localized to centroacinar cells. AQP8 is expressed on the apical plasma membrane (Hurley et al., 2001;
Tani et al., 2001), whereas AQP12, a relatively new member of the AQP family, is an intracellular water channel (Itoh et al., 2005). Several studies suggest that altered expression or functions of AQPs are often associated with different diseases affecting the kidney, colon, lacrimal, or salivary glands (Steinfeld et al., 2001; Tsubota et al., 2001; Bedford et al., 2003; Zhu et al., 2016). However, only scarce information is available regarding the role of AQPs in pancreatitis. Ohta et al. (2009) have shown that in the absence of AQP12 the course of cerulein-induced pancreatitis is much worse, probably due to the defect in the secretion of zymogens. In addition, decreased expression of AQP1 and -8 has been found in this pancreatitis model that may also affects the outcome of pancreatitis (Kitami et al., 2007).

The aim of this study is to provide the first detailed characterization regarding the role of AQPs in the pancreas, both under physiological and pathophysiological conditions and to study its relationship to the CFTR $\mathrm{Cl}^{-}$channel. We have chosen to focus on AQP1, since this isoform is abundantly expressed in both acinar and ductal cells of mouse and human pancreas and the role of this AQP has not been evaluated in pancreatitis yet. Using in vitro models, human tissues and transgenic mice, we have shown that AQP1 plays essential role in ductal fluid and $\mathrm{HCO}_{3}{ }^{-}$secretion, lack of CFTR decreases its expression and deletion of AQP1 is strongly associated with increased susceptibility of the gland to pancreatitis.

\section{MATERIALS AND METHODS}

\section{Ethical Approval}

Animal experiments were conducted in accordance with the Guide for the Care and Use of Laboratory Animals (United States, Department of Health and Human Services). In addition, the experimental protocol was approved by the local Ethical Board of the University of Szeged, Hungary and by the National Scientific Ethical Committee on Animal Experimentation (Budapest, Hungary). The use of human tissue was approved by the local ethical committee (University of Szeged, Hungary) and written informed consent was obtained from the patients.

\section{Transgenic Mice}

AQP1 knock out (KO) mice were a kind gift from Dr. Alan Verkman (University of California, CA, United States) and Dr. Alastair Poole (University of Bristol, United Kingdom). CFTR KO mice were kindly supplied by Dr. Ursula Seidler (Hannover Medical School, Hannover, Germany). Animals were kept in standard plastic cages on 12:12 h light-dark cycle at room temperature $\left(23 \pm 1^{\circ} \mathrm{C}\right)$ and had free access to standard or CFTR 
specific laboratory chow and drinking solutions. Functional experiments were performed on litter-matched (age 12-16 weeks, both sexes) wild-type (WT) and AQP1 KO mice. All mice were genotyped prior to the experiments. For genotyping, genomic DNA from the tail was isolated and amplified by traditional PCR.

\section{Human Pancreatic Tissue Samples}

Human pancreatic tissue samples were obtained from autopsy and from surgical resections. Control tissue $(n=5)$ were collected from the tumor-free region of the pancreas of patients with neuroendocrine tumors. Tissue samples from patients with acute necrotizing pancreatitis (ANP; $n=5)$ or $\mathrm{CP}(n=5)$ were from autopsy and from surgical resections. The average age of ANP patients was $56 \pm 2.8$ years, and the male/female ratio was 1.5:1. The average age of CP patients was $56.8 \pm 2.8$ years, and the male/female ratio was $4: 1$.

\section{Cell Cultures and Treatments}

Capan-1, Panc-1, and Miapaca-2 cells were obtained from the American Type Culture Collection (Manassas, VA, United States). Capan-1 cells were maintained in Roswell Park Memorial Institute (RPMI)-1640 Medium supplemented with $15 \%(\mathrm{v} / \mathrm{v})$ fetal bovine serum (FBS), $1 \%(\mathrm{v} / \mathrm{v})$ L-glutamine and $1 \%(\mathrm{v} / \mathrm{v})$ Penicillin-Streptomycin (PS). Panc-1 and Miapaca2 were maintained in Dulbecco's Modified Eagle's Medium (DMEM) high glucose Medium supplemented with $10 \%$ (v/v) FBS, $1 \%$ (v/v) L-glutamine, $2.5 \%$ (v/v) horse serum and $1 \%$ $(\mathrm{v} / \mathrm{v})$ PS. All three cell lines were kept in a humidified incubator at $37^{\circ} \mathrm{C}$. Cells from passage numbers $20-60$ were used in this study. In case of PCR experiments $10^{6}$, whereas in the case of immunostaining $10^{4}$ cells were seeded into $75 \mathrm{~cm}^{2}$ tissue culture flasks or glass bottom petri dishes, respectively, and incubated for $24 \mathrm{~h}$ at $37^{\circ} \mathrm{C}$. After the incubation, cells were treated with chenodeoxycholic acid (CDCA; 100, 300, and 500 $\mu \mathrm{M})$, glycochenodeoxycholic acid (GCDCA; 100, 300, and 500 $\mu \mathrm{M})$, ethanol (EtOH; 1, 10, and $100 \mathrm{mM}$ ), palmitoleic acid (POA; 10,100 , and $200 \mu \mathrm{M}$ ) and palmitoleic acid ethyl ester (POAEE; 10,100 and $200 \mu \mathrm{M}$ ) for $6,12,24$, and $48 \mathrm{~h}$ and the mRNA and protein expression were investigated by real-time PCR and immunohistochemistry.

\section{Chemicals and Solutions}

2,7-bis-(2-carboxyethyl)-5(6)-carboxyfluorescein acetoxymethyl ester (BCECF-AM) was from Invitrogen (Eugene, OR, United States). BCECF-AM (2 $\mathrm{mmol} / \mathrm{l})$ were prepared in dimethyl sulfoxide (DMSO) and stored at $-20^{\circ} \mathrm{C}$. POAEE was purchased from Cayman Chemical (Tallinn, Estonia). POA and POAEE were made up as a $10 \mathrm{mM}$ stock solution in DMSO and stored at $-20^{\circ} \mathrm{C}$. Chromatographically pure collagenase was purchased from Worthington (Lakewood, NJ, United States). All other chemicals were obtained from Sigma-Aldrich (Budapest, Hungary).

For microfluorimetry studies, the standard HEPES-buffered solution contained (in $\mathrm{mM}$ ): $130 \mathrm{NaCl}, 5 \mathrm{KCl}, 1 \mathrm{CaCl}_{2}, 1 \mathrm{MgCl}_{2}$, $10 \mathrm{D}$-glucose and $10 \mathrm{Na}$-HEPES. HEPES-buffered solutions were gassed with $100 \% \mathrm{O}_{2}$ and their $\mathrm{pH}$ was set to 7.4 with $\mathrm{HCl}$. The standard $\mathrm{HCO}_{3}{ }^{-} / \mathrm{CO}_{2}$-buffered solution contained (in $\mathrm{mM}$ ): $115 \mathrm{NaCl}, 25 \mathrm{NaHCO}_{3}, 5 \mathrm{KCl}, 1 \mathrm{CaCl}_{2}, 1 \mathrm{MgCl}_{2}$, and $10 \mathrm{D}-$ glucose. The $\mathrm{Cl}^{-}$-free $\mathrm{HCO}_{3}{ }^{-} / \mathrm{CO}_{2}$-buffered solution contained (in $\mathrm{mM}$ ): $115 \mathrm{Na}$-gluconate, $25 \mathrm{NaHCO}_{3}, 6 \mathrm{Ca}$-gluconate, 1 $\mathrm{Mg}$-gluconate, $2.5 \mathrm{~K} 2 \mathrm{H}$-sulfate, and $10 \mathrm{D}$-glucose. $\mathrm{HCO}_{3}{ }^{-} / \mathrm{CO}_{2}-$ buffered solutions were gassed with $95 \% \mathrm{O}_{2} / 5 \% \mathrm{CO}_{2}$ to set the $\mathrm{pH}$ to 7.4 .

\section{Isolation of Pancreatic Ducts and Measurement of Intracellular pH}

Intra/interlobular ducts were isolated from the pancreas of WT and AQP KO mice using the microdissection technique as described previously (Argent et al., 1986). Changes in intracellular $\mathrm{pH}\left(\mathrm{pH}_{\mathrm{i}}\right)$ were detected using the $\mathrm{pH}$-sensitive fluorescence dye, BCECF. Pancreatic ducts were incubated with BCECF-AM $(2 \mu \mathrm{M})$ for 30-60 min, at room temperature. After the incubation, ducts were attached to a cover glass, which formed the base of a perfusion chamber, mounted on the stage of an IX71 live cell imaging fluorescence microscope (Olympus, Budapest, Hungary) and excited at 440 and $490 \mathrm{~nm}$. Emissions were monitored at $530 \mathrm{~nm}$. Five to seven region of interests (ROIs) were examined in each experiment, and one measurement per second was obtained. The $490 / 440$ fluorescence ratio was calibrated to $\mathrm{pH}_{\mathrm{i}}$ using the high $\mathrm{K}^{+}$-nigericin technique, as previously described (Thomas et al., 1979; Hegyi et al., 2004).

\section{Measurement of $\mathrm{HCO}_{3}{ }^{-}$Secretion}

In order to estimate $\mathrm{HCO}_{3}{ }^{-}$efflux, the activity of the $\mathrm{Cl}^{-} / \mathrm{HCO}_{3}{ }^{-}$exchanger was measured by the $\mathrm{Cl}^{-}$withdrawal technique. Removal of luminal $\mathrm{Cl}^{-}$from the standard $\mathrm{HCO}_{3}{ }^{-} / \mathrm{CO}_{2}$-buffered solution induced an alkalization in the cells due to the reverse mode of the exchanger. Re-addition of $\mathrm{Cl}^{-}$induces $\mathrm{HCO}_{3}{ }^{-}$secretion via the $\mathrm{Cl}^{-} / \mathrm{HCO}_{3}{ }^{-}$exchanger. Under these conditions the initial rate of acidification reflects the activity of the $\mathrm{Cl}^{-} / \mathrm{HCO}_{3}{ }^{-}$exchanger. In order to evaluate base efflux $\left[-J\left(\mathrm{~B}^{-} / \mathrm{min}\right)\right]$ the following equation was used: $-J\left(\mathrm{~B}^{-} / \mathrm{min}\right)=\Delta \mathrm{pH} / \Delta \mathrm{t} \times \beta_{\text {total }}$, where $\Delta \mathrm{pH} / \Delta \mathrm{t}$ is the rate of acidification measured over the first $60 \mathrm{~s}$ and $\beta_{\text {total }}$ is the total buffering capacity of the cell.

\section{Measurement of in Vitro Ductal Fluid Secretion}

Fluid secretion of intra/interlobular pancreatic ducts was measured using a swelling method, as described previously (Fernandez-Salazar et al., 2004). Briefly, isolated pancreatic ducts were attached to a cover glass which formed the base of a perfusion chamber and mounted on the stage of an IX71 live cell imaging fluorescence microscope. Low magnification, brightfield images were acquired at 1-min intervals using a CCD camera (Hamamatsu ORCA-ER, Olympus, Budapest, Hungary). At the end of each experiment, ducts were perfused with hypotonic solution in order to check the integrity of the duct wall. Ducts that not respond to the hypotonic challenge were excluded from the analysis. Changes in relative luminal volume was analyzed by Scion Image software (Scion Corporation, Frederick, MD, United States) (Fernandez-Salazar et al., 2004; Pascua et al., 2009). 


\section{Measurement of in Vivo Pancreatic Fluid Secretion}

In order to measure pancreatic fluid secretion in vivo, magnetic resonance imaging (MRI) was performed on WT and AQP1 KO mice (Maleth et al., 2015). Animals were allowed free access to pineapple juice $12 \mathrm{~h}$ before the MRI examination. MRI was performed in a 7.1 Tesla animal scanner (Bruker, Ettlingen, Germany). Strong T2-weighted series of the complete abdomen were acquired before and after retroorbital injection of $10 \mathrm{IU}$ units/kg body weight (b.w.) secretin (ChiroStim, ChiRhoClin, Burtonville, MD, United States). The time between injection and MRI was $6 \mathrm{~min}$. The sequences were acquired using the image parameters: TR/TE $4400 / 83 \mathrm{~ms}$; flip angle: $180^{\circ}$; matrix $256 \times 256$; field of view $40 \times 40 \mathrm{~mm}$; bandwidth $315 \mathrm{~Hz} /$ pixel; slice thickness $1 \mathrm{~mm} ; 20$ slices. All image analyses were performed using Osirix (version 5; Pixameo, Bernex, Switzerland). In order to exclude effects of the basal secretion, MRI datasets after and before secretion were subtracted. The created images show the total excretion after secretin stimulation. Excreted fluid is defined as high signal intensity in created images. The fluid excretion into the small intestine was segmented in each slice. The software calculated the volume of the segmented areas. This volume represents the total excreted volume (TEV). In order to minimize artifacts, image noise was reduced.

\section{Measurement of Osmotic Transepithelial Water Permeability}

The osmotic transcellular water movement $\left(\mathrm{P}_{\mathrm{f}}\right)$ was estimated using the cell-impermeant dye, Texas $\operatorname{Red}^{\mathrm{TM}}$ Dextran as previously described (Levin et al., 2006). Briefly, cells $\left(5 \times 10^{5}\right)$ were grown on a polyester permeable support (Transwell, $12 \mathrm{~mm}$ diameter and $0.4 \mu \mathrm{m}$ pore size). Monolayer confluence was checked by measuring the transepithelial electrical resistance $\left(\mathrm{R}_{\mathrm{T}}\right)$ using an EVOM-G Volt/Ohm Meter (World Precision Instruments, Sarasota, FL, United States). Cells were washed with isoosmolar phosphate-buffered saline (PBS) from the basolateral surface and hyperosmolar PBS (complemented with $300 \mathrm{mM}$ D-mannitol and $0.25 \mu \mathrm{g} / \mathrm{mL}$ Texas Red Dextran) from the luminal surface. In some experiments, different concentrations of bile acids were added to the apical solution. Transwells were than placed into a $\mathrm{CO}_{2}$ incubator and $5 \mu \mathrm{l}$ samples were collected from the apical solution at specified time points. Water moves along the osmotic gradient that causes the dilution of the fluorescent dye, in the apical solution. Fluorescence was measured at $595 \mathrm{~nm}$ excitation and $615 \mathrm{~nm}$ emission, using a Fluoro Max-4 spectrofluorometer (Horiba Scientific, Tokyo, Japan). For the calculation of $\mathrm{P}_{\mathrm{f}}$ the following formula was used: $\mathrm{dV}(0) / \mathrm{dt}=\mathrm{P}_{\mathrm{f}}{ }^{*} \mathrm{~S}^{*} \mathrm{v}_{\mathrm{w}}{ }^{*}\left(\Phi_{1}-\Phi_{2}\right)$, where $S$ is the tissue surface area, $v_{w}$ is the partial molar volume of water and $\Phi_{1}-\Phi_{2}$ is the transepithelial osmotic gradient.

\section{Real-Time PCR}

Total RNA was purified from individual cell culture samples using the RNA isolation kit of Macherey-Nagel (Macherey-Nagel,
Düren, Germany). All the preparation steps were carried out according the manufacturer's instructions. RNA samples were stored at $-80^{\circ} \mathrm{C}$ in the presence of $30 \mathrm{U}$ of Prime RNAse inhibitor (Fermentas, Lithuania) for further analysis. The quantity of isolated RNA samples was checked by spectrophotometry (NanoDrop 3.1.0, Rockland, DE, United States). In order to monitor gene expression, QRT-PCR was performed on a RotorGene 3000 instrument (Corbett Research, Sydney, NSW, Australia) using the TaqMan probe sets of specific Aquaporin genes (Applied Biosystems, Foster City, CA, United States). Information about the genes and the TaqMan assays is collected in Table 1. $3 \mu \mathrm{g}$ of total RNA was reverse transcribed using the High-Capacity cDNA Archive Kit (Applied Biosystems, Foster City, CA, United States) according to the manufacturer's instructions in final volume of $30 \mu \mathrm{L}$. The temperature profile of the reverse transcription was the following: $10 \mathrm{~min}$ at room temperature, $2 \mathrm{~h}$ at $37^{\circ} \mathrm{C}, 5 \mathrm{~min}$ on ice and finally $10 \mathrm{~min}$ at $75^{\circ} \mathrm{C}$ for enzyme inactivation. These steps were carried out in a Thermal Cycler machine (MJ Research, Waltham, MA, United States). After dilution with $30 \mu \mathrm{L}$ of water, $1 \mu \mathrm{L}$ of the diluted reaction mix was used as template in the QRT-PCR. For all the reactions TaqMan Universal Master Mix (Applied Biosystems, Foster City, CA, United States) were used according to the manufacturer's instructions. Each reaction mixture (final volume $20 \mu \mathrm{L}$ ) contained $1 \mu \mathrm{L}$ of primer-TaqMan probe mix. The QRT-PCR reactions were carried out under the following conditions: $15 \mathrm{~min}$ at $95^{\circ} \mathrm{C}$ and 45 cycles of $95^{\circ} \mathrm{C}$ for $15 \mathrm{~s}$, $60^{\circ} \mathrm{C}$ for $1 \mathrm{~min}$. Fluorescein dye (FAM) intensity was detected after each cycle. Non-template control sample was used for each PCR run to check the primer-dimer formation. Relative gene expression ratios were calculated as $\Delta \mathrm{Ct}$ values (Ct values of gene of interest versus $\mathrm{Ct}$ values of human hypoxanthine phosphoribosyltransferase gene). In the case of treatments, relative changes in gene expression were determined using the $\Delta \Delta \mathrm{C}_{\mathrm{T}}$ method as described in Applied Biosystems User Bulletin No. 2 (P/N 4303859). $\Delta \Delta \mathrm{C}_{\mathrm{T}}$ was calculated using the following formula: $\Delta \Delta \mathrm{C}_{\mathrm{T}}=\Delta \mathrm{C}_{\mathrm{T}}$ of treated cells $-\Delta \mathrm{C}_{\mathrm{T}}$ of control, nontreated cells. The $\mathrm{N}$-fold differential expression in the target gene was expressed as $2^{-\Delta \Delta C_{\mathrm{T}}}$. Genes with expression values less than or equal to 0.5 were considered to be down-regulated, whereas values higher than or equal to 2 were considered to be upregulated. Values ranging from 0.51 to 1.99 were not considered to be significant.

\section{Immunocytochemistry}

CAPAN-1 cells were washed with PBS twice and fixed in paraformaldehyde ( $4 \%$ in PBS) for $30 \mathrm{~min}$ at room temperature (RT). In order to avoid non-specific antibody binding cells were incubated with $10 \%$ donkey serum and $1 \%$ BSA for further $30 \mathrm{~min}$. After blocking, cells were incubated with primary AQPs human, polyclonal antibodies (1:100 dilutions; Abcam, Cambridge, United Kingdom) at $4^{\circ} \mathrm{C}$ overnight. Petri dishes were then washed with PBS and incubated with FITC-conjugated AffiniPure Donkey AntiRabbit IgG secondary antibody (1:400 dilutions; DAKO, Milan, Italy) for $60 \mathrm{~min}$ at RT. Nuclei were counterstained with Dapi. Dishes were then mounted and observed by a 
TABLE 1 | TaqMan assays used for the investigation of AQP expression.

\begin{tabular}{llll}
\hline Definition & Gene symbol & Ref Seq Acc. number & ABI TaqMan assay ID \\
\hline Homo sapiens aquaporin 1 (Colton blood group) & AQP1 & NM_198098 & Hs00166067_m1 \\
Homo sapiens aquaporin 2 (collecting duct) & AQP2 & NM_000486 & Hs00166640_m1 \\
Homo sapiens aquaporin 3 (Gill blood group) & AQP3 & NM_004925 & Hs00185020_m1 \\
Homo sapiens aquaporin 4 & AQP4 & NM_001650 & Hs00242341_m1 \\
Homo sapiens aquaporin 5 & AQP5 & NM_001651 & Hs00387048_m1 \\
Homo sapiens aquaporin 6, kidney specific & AQP6 & NM_001652 & Hs01546883_m1 \\
Homo sapiens aquaporin 7 & AQP7 & NM_001170 & Hs00357359_m1 \\
Homo sapiens aquaporin 8 & AQP8 & NM_001169 & Hs00154124_m1 \\
Homo sapiens aquaporin 9 & AQP9 & NM_020980 & Hs00175573_m1 \\
Homo sapiens aquaporin 10 & AQP10 & NM_080429 & Hs00369738_m1 \\
Homo sapiens aquaporin 11 & AQP11 & NM_173039 & Hs016542681_m1 \\
Homo sapiens aquaporin 12A & AQP12A & NM_198998 1 \\
Homo sapiens aquaporin 12B & AQP12B & NM_001102467.1 &
\end{tabular}

Fluowiew 10i-W confocal microscopy (Olympus, Budapest, Hungary).

\section{Immunohistochemistry}

Paraffin-embedded, 3- to $4-\mu \mathrm{m}$-thick sections of surgically removed resection specimens and autopsy tissue samples were used for immunohistochemistry. After deparaffinization of tissue samples with EZ Prep Concentrate 10X (Ventana Medical Systems, Tucson, AZ, United States), endogenous peroxidase blocking and antigen retrieval (CC1; Ventana Medical Systems), pancreas sections were incubated with polyclonal AQP1 antibody (1:100 dilution; Alomone Labs, Jerusalem, Israel) overnight at $4^{\circ} \mathrm{C}$. Immunohistochemical staining was performed with horseradish peroxidase multimer-based, biotin-free detection technique according to the protocol of the automated Ventana system (Ventana Benchmark XT; Ventana Medical Systems). For visualization, the UltraView Universal diaminobenzidine (DAB) Detection Kit (Ventana Medical Systems) was applied. Sections from human pancreas were used as positive controls. For negative control, primary antibodies were substituted with antibody diluent (Ventana Medical Systems). The stained slides were digitized with Mirax Pannoramic MIDI and Mirax Pannoramic SCAN digital slide scanners (3DHistech Ltd., Budapest, Hungary).

Cryosections from WT, AQP1, and CFTR KO mice pancreas were fixed in $2 \%$ paraformaldehyde, permeabilized in $10 \%$ Tween 20 -sodium citrate, blocked with $5 \%$ goat serum followed by immunofluorescent double staining for AQP1 mouse monoclonal antibody (1:500 dilutions; Thermo Fisher, Rockford, IL, United States) and CFTR rabbit polyclonal antibody (1:100 dilutions; Alomone Labs, Jerusalem, Israel) at $4^{\circ} \mathrm{C}$, overnight. Following washing, sections were incubated with secondary antibodies goat-anti-mouse (Alexa fluor 488, Thermo Fisher, Rockford, IL, United States) and goat-anti-rabbit (Alexa fluor 568, Thermo Fisher, Rockford, IL, United States) for $2 \mathrm{~h}$ at room temperature in the dark. Nuclei were counterstained with Dapi. Sections were then mounted and analyzed using a Zeiss LSM 880 confocal laser scanning microscope (Carl Zeiss Technika Kft., Budaörs, Hungary).

\section{Quantification of the Immunostainings}

In order to quantify AQP1 or CFTR positively stained area, 10-12 representative, digital images were taken from the human (normal pancreas, AP and CP) and mice (WT, AQP1 KO and CFTR KO) pancreas sections and from Capan-1 cells. Pictures were than converted to gray scale (16-bit) and thresholded in order to select the positively stained area, using the ImageJ software. The intensity of DAB (human pancreas) or fluorescence signal (mice pancreas and Capan-1 cells) varied on an arbitrary scale from 0 to 255 , where 0 is the negative staining (white pixels) and 255 is the maximal staining (black pixels). In the human samples, the mean integrated density of the positively stained area was normalized to the mean integrated density of the total image and converted into percentage. In the cell line, the mean integrated density of the positively stained area was normalized to the total cell number and expressed in arbitrary units. In the mice samples, the ductal area was selected and the total fluorescence intensity was calculated and summarized which was than normalized to the ductal area $\left(\mu \mathrm{m}^{2}\right)$ and expressed in arbitrary units $/ \mu \mathrm{m}^{2}$. Comparison of each groups were calculated by one-way ANOVA, followed by the Holm-Sidak method. Statistical significance was defined as $p \leq 0.05$. Data are expressed as means \pm SEM.

\section{Induction of Acute Pancreatitis in Mice}

Acute pancreatitis (AP) was induced in mice by hourly (10 times) intraperitoneal (i.p.) injections of cerulein $(50 \mu \mathrm{g} / \mathrm{kg})$ (Niederau et al., 1985; Ding et al., 2003; Pallagi et al., 2014) following anesthesia with i.p. $85 \mathrm{mg} / \mathrm{bwkg}$ pentobarbital (Bimeda MTC, Cambridge, ON, Canada). The control animals received the same amount of saline. Two hours after the final injection, mice were euthanized by pentobarbital overdose $(200 \mathrm{mg} / \mathrm{bwkg}$ i.p.). Animals were exsanguinated through the cardiac puncture and the pancreata were immediately removed. The collected blood was centrifuged at $4^{\circ} \mathrm{C}$ with $2500 \mathrm{RCF}$ for $15 \mathrm{~min}$ and the sera were stored at $-20^{\circ} \mathrm{C}$ until use. The pancreas was trimmed from fat and lymphatic tissue, put into $6 \%$ neutral formaldehyde solution and stored at $-80^{\circ} \mathrm{C}$ until use. Serum amylase activity was measured with a commercial colorimetric kit 
(Diagnosticum, Budapest, Hungary) with a FLUOstar OPTIMA (BMG Labtech, Budapest, Hungary) microplate reader at $405 \mathrm{~nm}$. The formaldehyde-fixed pancreatic tissue was embedded in paraffin blocks, cut into $3 \mu \mathrm{m}$ thick sections and stained for hematoxylin-eosin using standard techniques and viewed by light microscopy. A semiquantitative scoring system was used to evaluate the presence of edema, the rate of necrosis and infiltration of inflammatory cells according to the following scoring system (Kui et al., 2015): Edema (0: none, 1: patchy interlobular; 2: diffuse interlobular; 3: diffuse interlobular, and intraacinar), necrosis (0: none, 1 : patchy interlobular; 2 : diffuse interlobular; 3: diffuse interlobular and patchy intraacinar; 4: diffuse interlobular and intraacinar) and leukocytic infiltration (0: none; 1: patchy interlobular; 2: diffuse interlobular; 3 : diffuse interlobular and intraacinar). The rate of necrosis was expressed as percentage of the total analyzed pancreatic area.

\section{Statistical Analysis}

Data are expressed as means \pm SEM. In the case of pancreatic fluid and $\mathrm{HCO}_{3}{ }^{-}$secretion measurements, significant difference between groups was determined by ANOVA. Statistical analysis of the immunohistochemical data was performed using the Student's $t$-test. Probability values of $p \leq 0.05$ were accepted as being significant.

\section{RESULTS}

\section{Capan-1 Cells Express Functionally Active AQPs}

The relative gene expressions of $\mathrm{AQP}$ isoforms were studied in different pancreatic ductal cell lines (Capan-1, Panc-1, and Miapaca-2) using RT-PCR and TaqMan primer-probe sets, specific for AQP1-AQP12 isoforms (Table 1). Expressions of $\mathrm{AQPs}$ were investigated at different time points $(6,12,24$, and $48 \mathrm{~h}) 24 \mathrm{~h}$ after plating the cells, and as an internal gene, human hypoxanthine phosphoribosyltransferase (HPRT) was used. RTPCR analysis revealed that among the three cell lines, AQPs were expressed at the highest level in Capan-1 cells, whereas in Panc-1 and Miapaca-2 the expression of AQPs was hardly detectable (Figures 1A-C). In Capan-1 cells high levels of AQP1, -3 , and -5 was detected, which is in agreement with previous observations (Burghardt et al., 2003). The presence of these isoforms was also confirmed at protein level in the Capan-1 cells (Figure 1D). In order to test that the AQPs expressed on Capan1 cells are functionally active, we investigated the transepithelial water flow in the presence and absence of the non-specific AQP inhibitor $\mathrm{HgCl}_{2}$. As shown in Figures 1E,F, administration of $0.3 \mathrm{mM} \mathrm{HgCl}_{2}$ to the apical solution inhibited the osmotic water movement by $52.6 \pm 2.4 \%$, indicating that significant proportion of water is transported through AQPs.

\section{AQP1 Is Essential for Pancreatic Ductal Fluid and $\mathrm{HCO}_{3}$ - Secretion}

Aquaporins are involved in transepithelial water transport in numerous tissues (Tradtrantip et al., 2009). In the next step, we investigated the role of this protein in pancreatic ductal fluid secretion using gene modified mice. Using traditional PCR we have shown the presence of AQP1 both in the isolated, intra/interlobular pancreatic ducts and the total pancreas (Figure 2A). Slight expression of AQP5 was also detected in the pancreatic ducts, whereas the mRNA presence of AQP8 and -12 was only observed in the total pancreas (data not shown). We decided to characterize the role of AQP1, since this isoform is constitutively expressed in both the ductal and acinar cells and also can be found in the mouse and human pancreas (Table 2). In contrast to AQP1, AQP3 is not expressed in the mouse pancreas and this isoform is either involved in tumor progression than pancreatitis (Direito et al., 2017; Huang et al., 2017). Although AQP5 is present in the intra/interlobular pancreatic ducts of mice and human, and probably plays role in ductal fluid secretion (Burghardt et al., 2003), KO animal for this isoform was not available to us. Table 2 summarizes the presence of AQP isoforms in mice and human.

The rate of fluid secretion was measured over $30-40 \mathrm{~min}$ using sealed ducts and the swelling technique. Initially, ducts were perfused with the standard HEPES-buffered solution and then perfusion was switched to $\mathrm{HCO}_{3}{ }^{-} / \mathrm{CO}_{2}$-buffered solution to initiate $\mathrm{HCO}_{3}{ }^{-}$-dependent secretion. As shown in Figure 2B, the presence of $\mathrm{HCO}_{3}{ }^{-}$induced a dynamic swelling of the WT ducts as a result of fluid secretion into the closed luminal space. In contrast, ducts from AQP1 KO mice showed no or only a slight response to $\mathrm{HCO}_{3}{ }^{-}$. Under stimulated conditions (forskolin; $10 \mu \mathrm{M}$ ), the rate of fluid secretion further increased in the WT ducts, whereas in the case of KO ducts, no response was detected. Figure $\mathbf{2 C}$ summarizes the relative luminal volume changes in WT and KO ducts after forskolin stimulation. As shown in Figure 2C, the relative luminal volume increase reduced by $89.9 \pm 6.2 \%$ in the absence of $A Q P 1$, indicating that this $A Q P$ isoform plays an essential role in fluid secretion.

We also investigated the rate of pancreatic fluid secretion in vivo by MRI cholangiopancreatography in anesthetized mice. Fluid secretion was stimulated by retroorbital administration of $10 \mathrm{U} / \mathrm{kg}$ b.w. secretin, and then TEV was measured in WT and KO animals. Similarly, to the in vitro measurements, the pancreatic fluid secretion significantly reduced in AQP1 KO $\left(0.0041 \mathrm{TEV} / \mathrm{cm}^{3}\right)$ vs. WT $\left(0.023 \mathrm{TEV} / \mathrm{cm}^{3}\right)$ mice (Figures 2D,E).

Next, we were curious whether the decreased ductal fluid secretion is also associated with impaired $\mathrm{HCO}_{3}{ }^{-}$efflux in AQP1 $\mathrm{KO}$ animals. For the measurement of ductal $\mathrm{HCO}_{3}{ }^{-}$secretion, intra/interlobular pancreatic ducts were isolated from the pancreas of WT and AQP1 KO mice. Ducts were perfused both from the luminal and basolateral membrane with $\mathrm{HCO}_{3}{ }^{-} / \mathrm{CO}_{2}-$ buffered solution. Removal of $\mathrm{Cl}^{-}$from the apical solution induced an alkalisation inside the cells, due to the reverse mode of the $\mathrm{Cl}^{-} / \mathrm{HCO}_{3}{ }^{-}$exchanger. Addition of $\mathrm{Cl}^{-}$back to the external solution decreased the $\mathrm{pH}_{\mathrm{i}}$ indicating $\mathrm{HCO}_{3}{ }^{-}$efflux through the exchanger. Under these conditions, the initial rate of recovery from alkalosis reflects the activity of the $\mathrm{Cl}^{-} / \mathrm{HCO}_{3}{ }^{-}$exchanger $\left[\left(-J\left(\mathrm{~B}^{-} / \mathrm{min}\right)\right]\right.$. Using this technique, we showed that the rate of acidification significantly reduced in AQP1 KO $(42 \pm 3.2 \%)$ vs. WT ducts indicating that pancreatic ductal $\mathrm{HCO}_{3}{ }^{-}$secretion is impaired in the absence of AQP1 (Figures 2F,G). 


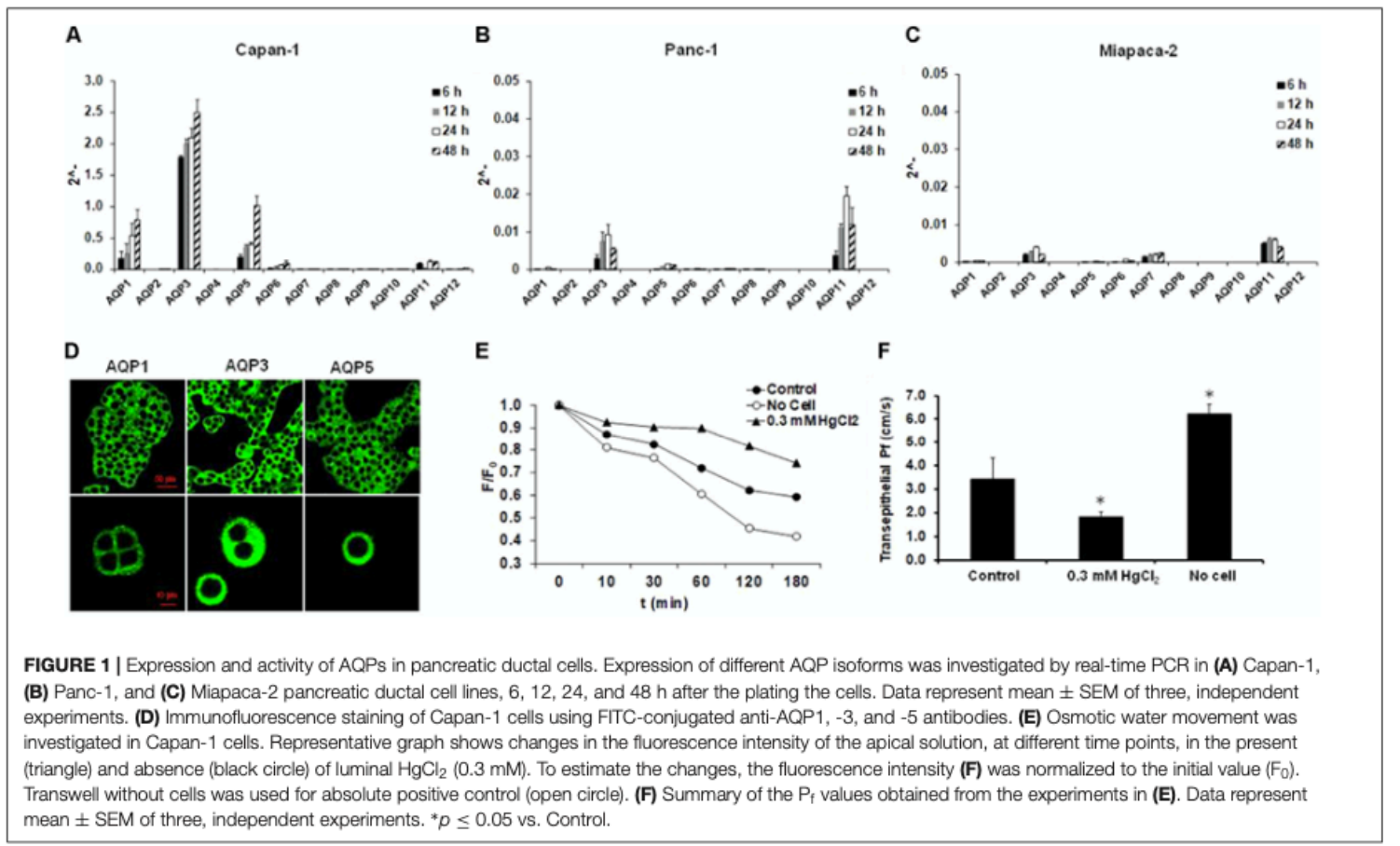

\section{AQP1 Expression Decreased in CFTR KO Mice}

The decreased $\mathrm{HCO}_{3}{ }^{-}$secretion in AQP1 KO mice indicates that beside the transport of water, AQP1 interacts with one or more ion transporters which are involved in $\mathrm{HCO}_{3}{ }^{-}$secretion. The CFTR $\mathrm{Cl}^{-}$channel plays essential role in ductal $\mathrm{HCO}_{3}{ }^{-}$ secretion by maintaining a luminal $\left[\mathrm{Cl}^{-}\right]$which is necessary for $\mathrm{HCO}_{3}{ }^{-}$efflux through the $\mathrm{Cl}^{-} / \mathrm{HCO}_{3}{ }^{-}$exchanger. Several studies presume a physical interaction between the CFTR $\mathrm{Cl}^{-}$ channel and certain AQP isoforms (Schreiber et al., 1999; Cheung et al., 2003; Jesus et al., 2014a,b). Colocalization of this two channel has also been found in the human pancreas (Burghardt et al., 2003). In the following step, we performed immunostaining on the pancreas of AQP1 and CFTR KO mice in order to characterize the possible relation between the two channels. In WT mice, AQP1 expression was detected throughout the whole plasma membrane, whereas expression of CFTR exclusively localized to the apical membrane of the ducts (Figure 3A). The absence of AQP1 caused a slight but not significant decrease in the expression of CFTR, indicating that the impaired $\mathrm{HCO}_{3}{ }^{-}$ secretion in the AQP1 KO mice is not due to the decreased expression of CFTR (Figure 3A, middle line). Interestingly we have found that expression of $\mathrm{AQP1}$ dramatically decreased in the intra/interlobular ducts of CFTR KO mice, especially at the apical membrane (Figure 3A, bottom line and Figure 3B). We have also found that the absence of CFTR did not affect the expression of AQP1 in the blood vessels indicating that some kind of interaction may exist between these two channels in the pancreatic ductal cells. Although further investigations are needed to clarify whether the two channels are able to regulate each others function, expression or trafficking.

\section{Expression and Function of AQPs Significantly Decreased After Bile Acid Treatment}

In the next step, we studied the effect of pancreatitis-inducing factors on the expression of AQP1. Gallstone obstruction and heavy alcohol consumption are the two major causes of pancreatitis. Capan-1 cells were treated with CDCA and GCDCA $(100,300$, and $500 \mu \mathrm{M})$ (Venglovecz et al., 2008, 2011; Muili et al., 2013), EtOH (1, 10, and $100 \mathrm{mM}), \mathrm{POA}$ and POAEE $(10,100$, and $200 \mu \mathrm{M})$ (Criddle et al., 2006; Judak et al., 2014; Maleth et al., 2015) for 6, 12, 24, and $48 \mathrm{~h}$ and the mRNA expressions of AQP1 were analyzed by RT-PCR. Among the investigated agents, CDCA had the most marked effect, it dose- and time-dependently decreased the expression of AQP1 (Figure 4A). GCDCA, POA, and POAEE caused a significant decrease at 12 and $24 \mathrm{~h}$, primarily at higher doses, which partially regenerated after $48 \mathrm{~h}$ in the continuous presence of the agents (Supplementary Figures 1A-C). In contrast to bile acids, EtOH initially ( $24 \mathrm{~h}$ ) increased the expression of AQP1 that was followed by a decrease (Supplementary Figure 1D). In order to decide whether the downregulating effect of CDCA can also be observed at protein level, we performed immunostaining on the CDCA-treated cells, using specific antibodies against AQP1. CDCA dose- and time-dependently 


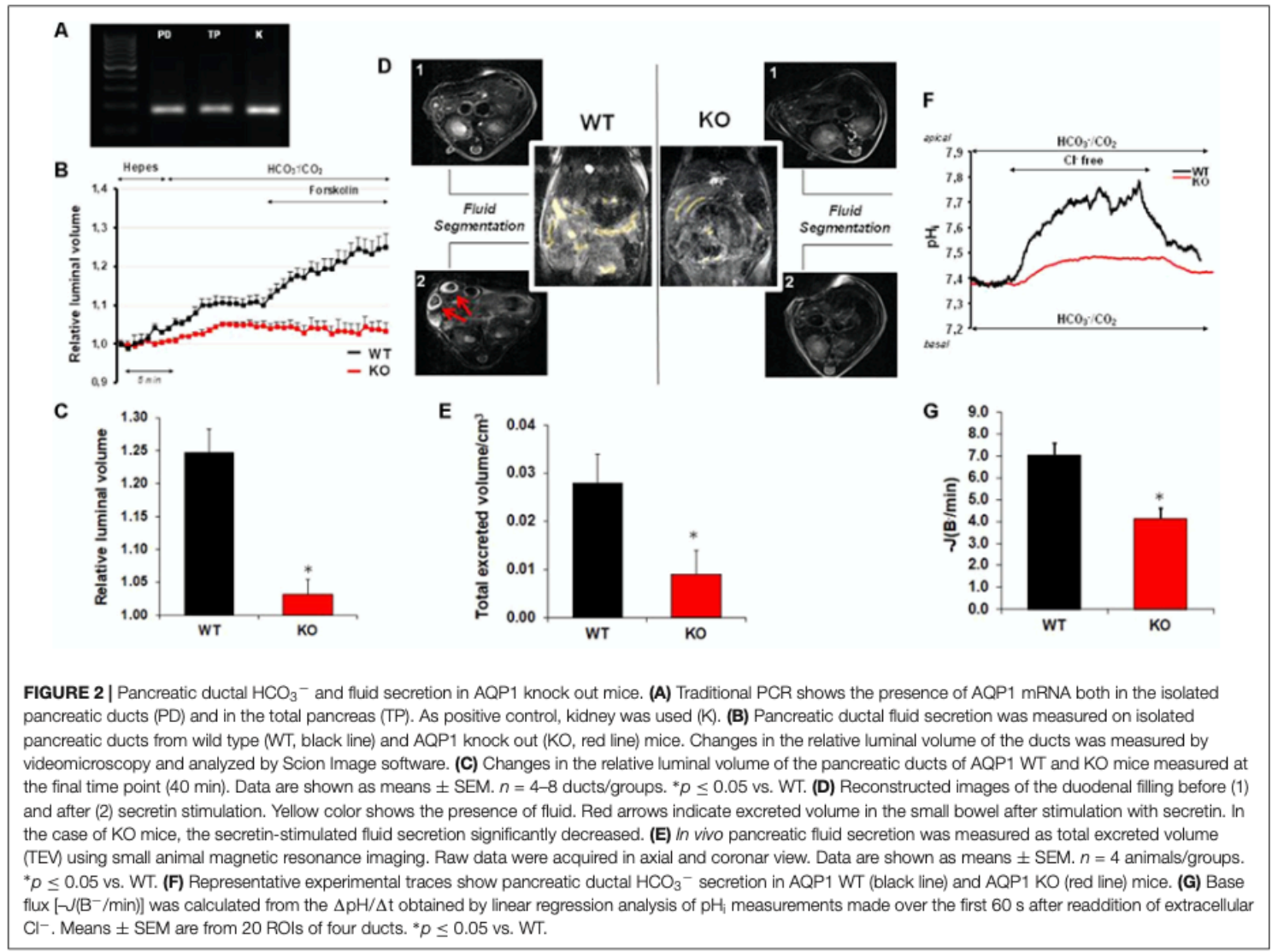

TABLE 2 | mRNA expression of AQP isoforms in mice and human

\begin{tabular}{|c|c|c|c|c|c|}
\hline Known isoforms & $\begin{array}{l}\text { Isoforms in mice } \\
\text { pancreas }\end{array}$ & $\begin{array}{l}\text { Isoforms in mice } \\
\text { pancreatic ducts }\end{array}$ & $\begin{array}{l}\text { Isoforms in human } \\
\text { pancreas }\end{array}$ & $\begin{array}{l}\text { Isoforms in human } \\
\text { pancreatic ducts }\end{array}$ & Available KO mice \\
\hline AQPO & - & - & - & - & - \\
\hline AQP1 & $\sqrt{ }$ & $\sqrt{ }$ & $\sqrt{ }$ & $\sqrt{ }$ & $\sqrt{ }$ \\
\hline AQP2 & - & - & - & - & - \\
\hline AQP3 & - & - & - & $\sqrt{ }$ & - \\
\hline AQP4 & - & - & - & - & $\sqrt{ }$ \\
\hline AQP5 & $\sqrt{ }$ & $\sqrt{ }$ & $\sqrt{ }$ & $\sqrt{ }$ & - \\
\hline AQP6 & - & - & - & - & - \\
\hline AQP7 & - & - & - & - & - \\
\hline AQP8 & $\sqrt{ }$ & - & $\sqrt{ }$ & - & - \\
\hline AQP9 & - & - & - & - & - \\
\hline AQP10 & - & - & - & - & - \\
\hline AQP11 & - & - & - & - & - \\
\hline AQP12 & $\sqrt{ }$ & - & $\sqrt{ }$ & - & - \\
\hline
\end{tabular}

decreased the protein expression of AQP1 was consistent with the PCR data (Figure 4B). Representative ICC pictures show that incubation with $500 \mu \mathrm{M}$ CDCA time-dependently decreased the AQP expression in the cells (Figure 4C). The effect of
CDCA on the activity of AQPs was also investigated. As shown in Figure 4D, 100 and $300 \mu \mathrm{M}$ CDCA had no effect on the transepithelial water movement, however, at $500 \mu \mathrm{M} \mathrm{P}_{\mathrm{f}}$ was significantly impaired. 
A
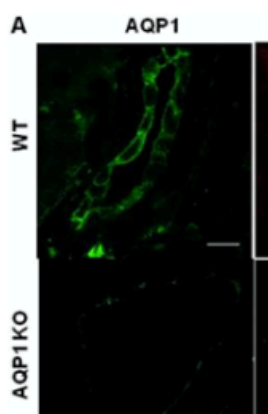

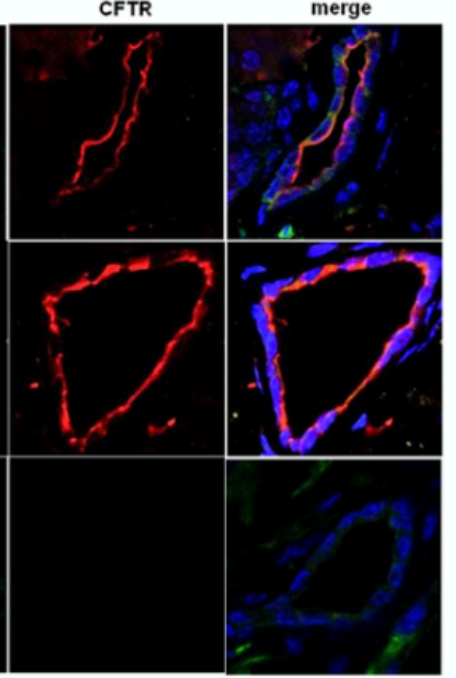

FTR
B

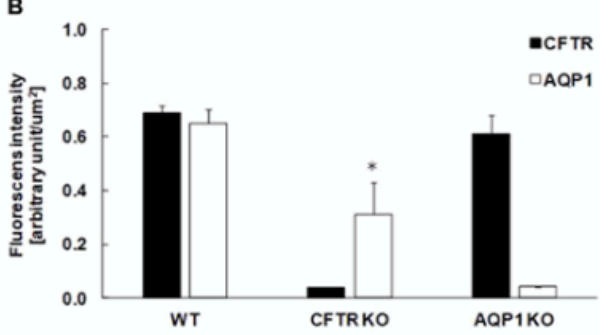

FIGURE 3 | Expression of AQP1 and CFTR in the pancreas of knock out mice. (A) Representative immunofluorescence staining of AQP1 and CFTR in wild type (WT, upper line), AQP1 knock out (AQP1 KO, middle line) and CFTR KO (bottom line) mice. Pictures were taken at 40x magnification. Pancreas slices were excited at 405 (Dapi), 488 (Alexa fluor 488) and 568 (Alexa fluor 568) nm and emissions were collected at 453, 516, and $603 \mathrm{~nm}$, respectively. Scale bar represents $10 \mu \mathrm{m}$. (B) Summary bar chart shows the mean fluorescence intensity in the ductal cells normalized to the ductal area and expressed in arbitrary units $/ \mu \mathrm{m}^{2}$. Data are presented as means \pm SEM. ${ }^{*} p \leq 0.05$ vs. WT (AQP1), $n=5$.

\section{Acute Pancreatitis Is Aggravated in AQP1 KO Mice}

In order to test the hypothesis that AQP1 may be involved in the pathomechanism of pancreatitis, we investigated the severity of cerulein-induced AP in WT and AQP1 KO mice. WT and AQP1 KO mice were given 10 hourly injections of either physiological saline (control) or supramaximal doses of cerulein (50 $\mu \mathrm{g} / \mathrm{kg}$ per injection) i.p. to induce AP. After saline injection, the pancreas had normal histology in both WT and $\mathrm{KO}$ animals. In contrast, i.p. injections of cerulein caused extensive cell damage both in the WT and KO animals. The extension of pancreatic necrosis were markedly higher in the AQP1 KO $(25 \pm 2.8 \%)$ vs. WT mice $(12.1 \pm 3.2 \%)$, whereas no differences were observed in the extent of edema and in the infiltration of inflammatory cells (Figures 5A-C). Serum amylase activities were significantly higher in KO (1605 \pm 6 $\mathrm{U} / \mathrm{l})$ vs. WT mice $(1285 \pm 51 \mathrm{U} / \mathrm{l})$ after the induction of AP (Figure 5D). As shown on the representative histological images (Figure 5E), the rate of pancreatic necrosis was more extensive in AQP1 KO mice. Overall, these results indicate that in the absence of AQP1 the course of pancreatitis is more severe.

\section{Expression of AQP1 Is Decreased in Acute and Chronic Pancreatitis}

Since we found that the lack of AQP1 exacerbates the course of cerulein-induced pancreatitis in mice, we tested whether this water channel is also involved in the pathomechanism of pancreatitis in humans. Therefore, in the next step we investigated the expression of AQP1 in pancreatic tissues samples obtained from five patients with ANP and five patients with CP. Control pancreatic tissue were obtained from tumorfree tissue surrounding neuroendocrine pancreatic tumors. In order to localize AQP1, IHC was performed. In the normal pancreas, strong AQP1 immunoreactivity was detected in the intra/interlobular and intercalated ducts, the acinar and centroacinar cells (Figures 6A-C). The staining in acinar cells and smaller ducts is mainly localized to the lateral and apical surface of the cells (Figures 6B,C). In the interlobular ducts, the apical plasma membrane was positive to AQP1 with some cytoplasmic staining, whereas Langerhans islets were completely negative for AQP1. These results are consistent with previous observations (Burghardt et al., 2003). In the ANP and CP pancreatic tissue sections the expression of AQP1 strongly reduced in the interlobular ducts, whereas intralobular and intercalated ducts still exhibited weak to moderate AQP1 immunoreactivity (Figures 6D-G). In case of acinar cells, the expression of AQP1 slightly decreased in the inflamed pancreas, especially in ANP. Quantification of DAB intensity showed that AQP1 staining was significantly higher in normal pancreas vs. the ANP or CP groups (Figure $6 \mathrm{H}$ ).

\section{DISCUSSION}

Acute and chronic pancreatitis are serious disorders characterized by inflammation and injury of the gland. 


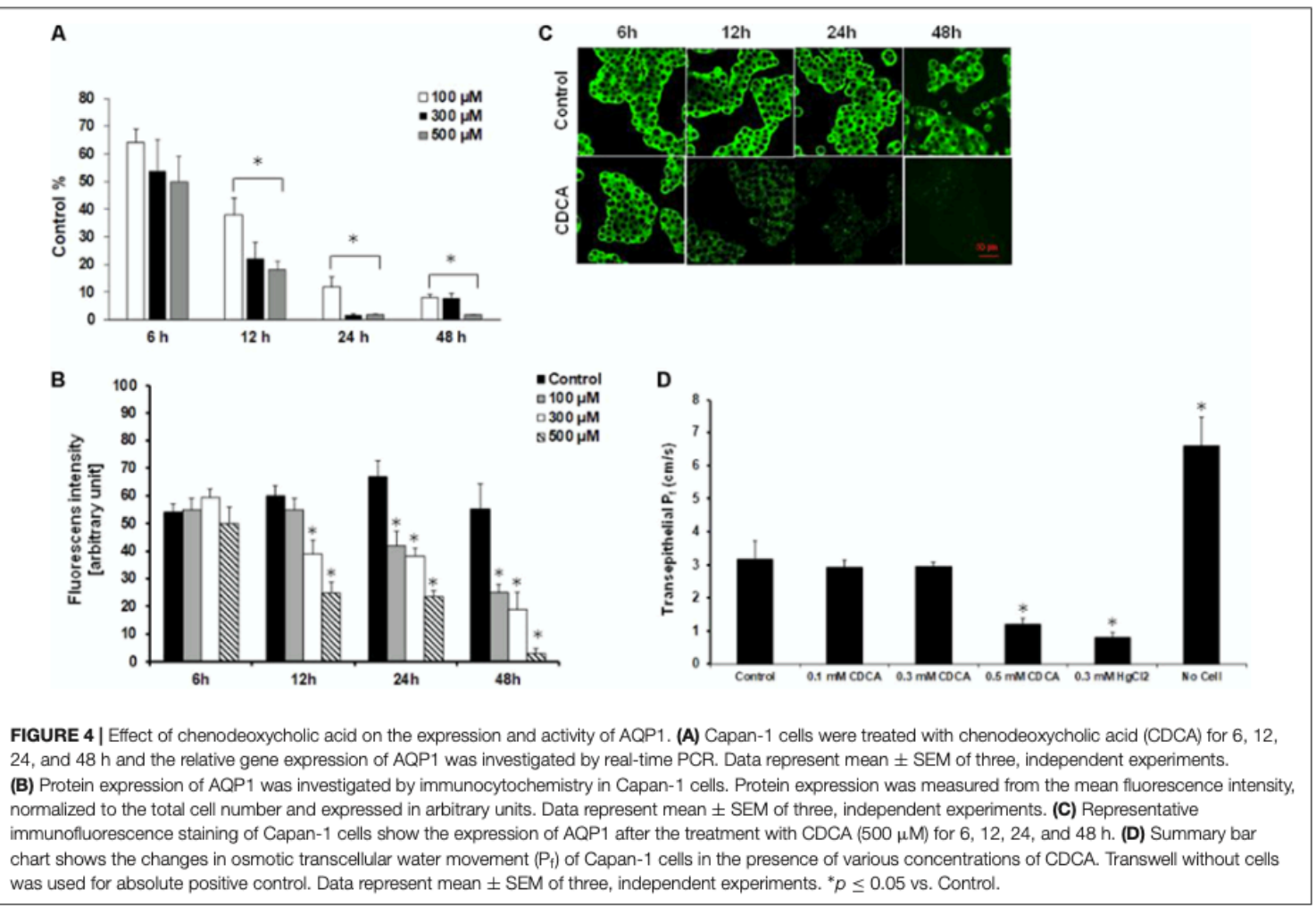

Gallstones and heavy alcohol consumption are responsible for approximately $80 \%$ of all AP patients (Parniczky et al., 2016), whereas alcohol abuse is the primary cause of CP (Szucs et al., 2017). Although the therapy improved a lot in the last few years the morbidity and mortality of pancreatitis is still excessively high (Parniczky et al., 2016). Defects in ductal fluid secretion have been proposed as an important factor in the pathomechanism of pancreatitis (Hegyi et al., 2011b). This fluid is high in $\mathrm{HCO}_{3}{ }^{-}$ which prevents the premature activation of zymogens and provides an optimal environment in the duodenum for the action of digestive enzymes. The secreted fluid is also beneficial from the point of view that washing out the potential toxic factors such as activated digestive enzymes or bile acids from the ductal tree and therefore prevents the pancreas from their damaging effects (Venglovecz et al., 2008). AQP1 is a water channel that extensively expressed in the acinar and ductal cells where mediates pancreatic fluid production. Several studies indicate that altered expression or localization of AQPs associates with different gastrointestinal disorders, such as gastritis or diarrhea; therefore, many studies have been conducted to identify the specific role of particular AQP isoforms. Although, AQP1 plays an essential role in pancreatic physiology its function under pathological conditions is not known.

In the present study, we showed that (i) bile acids strongly decrease the expression of AQPs in pancreatic ductal cells, (ii) chronic or acute inflammation of the pancreas is associated with decreased expression of $A Q P 1$, (iii) the absence of $A Q P 1$ reduces ductal fluid and $\mathrm{HCO}_{3}{ }^{-}$secretion, (iv) and induces a more severe pancreatitis in a cerulein-induced pancreatitis model.

Basically there are two ways for water transport. One is the paracellular way along the osmotic gradient generated by the ion transporters and the other one is the transcellular pathway through the AQPs. In case of the pancreatic ducts, it is not clear which pathway is the dominant. The pancreatic ductal epithelium is a moderately leaky epithelium which favors the paracellular movement of water (Novak and Greger, 1988). Nevertheless, administration of luminal $\mathrm{Hg}^{2+}$, a non-specific inhibitor of AQPs, decreased ductal fluid secretion by more than $90 \%$ in rat pancreatic ducts, which strengthen the importance of transcellular pathway (Ko et al., 2002). In the present study, we demonstrated that pancreatic ductal cells express functionally active AQPs. We have identified the presence of AQP1, -3, and -5 on the ductal cells that are consistent with previous observations (Burghardt et al., 2003). Treatment of the cells with pancreatitis-inducing agents, mostly decreased the expression of AQPs both at mRNA and protein levels. Among the investigated agents, CDCA had the biggest effect, which dose- and timedependently decreased the expression of AQP1. These data are partly consistent with previous findings in the colon, where bile acid treatment reduced the protein expression of AQP3, 

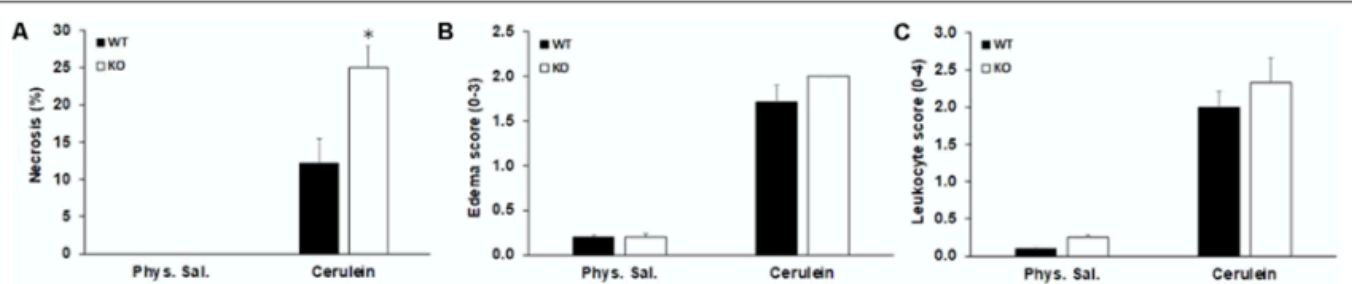

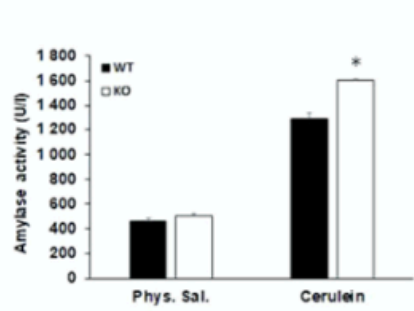

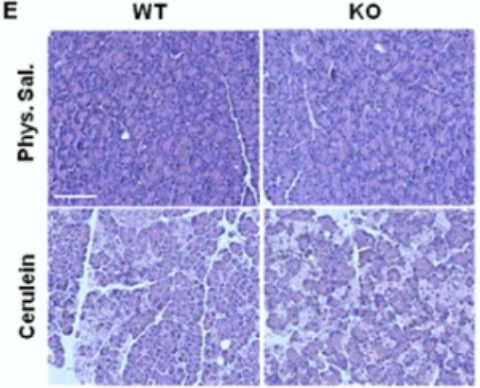

FIGURE 5 | Characterization of acute pancreatitis in AQP1 knock out mice. (A) Pancreatic cell necrosis, (B) edema, (C) leukocyte infiltration, and (D) serum amylase activity (U/I) were measured in wild-type (WT) and AQP1 knock out (KO) mice after induction of pancreatitis. Control animals received the same amount of saline. Data are presented as means \pm SEM. ${ }^{*} p \leq 0.05$ vs. WT. (E) Representative histological images show pancreatic sections from control (physiological saline) and cerulein-treated animals. Phys sal., physiological saline. Scale bar represents $50 \mu \mathrm{m}$.

whereas increased the levels of AQP7 and -8 (Yde et al., 2016). In case of $\mathrm{EtOH}$, the expression of $\mathrm{AQPs}$ initially increased (presumably due to a compensatory mechanism), then a decrease was observed, similarly to the rat stomach, where intragastrical administration of $1 \mathrm{mM}$ EtOH caused analogous changes in the expression of AQPs (Bodis et al., 2001). High concentration of CDCA also decreased the activity of the water channels, which is somewhat related to our previous findings on guinea pig pancreatic ducts, where $1 \mathrm{mM}$ CDCA strongly inhibited ductal $\mathrm{HCO}_{3}{ }^{-}$and thus fluid secretion (Venglovecz et al., 2008). The involvement of AQP1 in epithelial water movements has been described in various tissues, although there is still no consensus among researchers regarding the functional importance of this water channel (Marples, 2000). In cholangiocytes, the absence of AQP1 does not affect the fluid secretion (Mennone et al., 2002), although inhibition of the secretin-induced translocation of AQP1 reduces bile flow more than half (Marinelli et al., 1997, 1999). It has been also demonstrated that inhibition of $\mathrm{AQPs}$ by $\mathrm{HgCl}_{2}$ dose-dependently reduced the osmotically induced volume increase in these cells (Roberts et al., 1994). In the kidney, the absence of AQP1 dramatically decreased the urine concentrating ability of mice due to the impaired water permeability of the proximal tubule, limb of Henle and vasa recta (Ma et al., 1998; Schnermann et al., 1998; Pallone et al., 2000). The importance of AQP1 has been also highlighted in the brain where cerebrospinal fluid production decreased by fivefold in mice lacking AQP1 (Oshio et al., 2004).

In order to determine the role of AQP1 in pancreatic fluid secretion, we used AQP1 KO mice. No differences were observed in body weight and physical appearance between WT and KO mice, although the lifespan of AQP1 deficient mice was slightly lower. Using both in vitro and in vivo approaches, we found that fluid and $\mathrm{HCO}_{3}{ }^{-}$secretion significantly reduced in the absence of AQP1. These data are partly in contrast with previous observations demonstrating that defect in AQP1 expression cause only a small, but not significant decrease in the rate of stimulated pancreatic fluid secretion (Ma et al., 2001). Although this discrepancy can be explained by the different methods used for the measurement of pancreatic fluid. Nevertheless, other studies have found that decreased expression or function of AQP1 dramatically reduce ductal fluid secretion (Ko et al., 2002; Gabbi et al., 2008). Ko et al. (2002) have shown that luminal or basolateral administration of $\mathrm{HgCl}_{2}$ dose-dependently decrease the fluid secretory rate and osmotic water permeability of isolated pancreatic ducts. It has been also described that the defect in pancreatic fluid secretion in liver $\mathrm{X}$ receptor $\beta$-deficient mice is related to the decreased expression of AQP1 in the pancreatic ducts of these mice (Gabbi et al., 2008).

In order to identify the mechanism by which AQP1 influences ductal $\mathrm{HCO}_{3}{ }^{-}$secretion, we investigated the relation of this channel with the CFTR $\mathrm{Cl}^{-}$channel. CFTR is a cAMP-activated $\mathrm{Cl}^{-}$channel, which primarily located at the apical membrane of epithelial cells and plays a crucial role in the maintenance of fluid homeostasis. Growing number of studies indicate that a molecular interaction exists between CFTR and certain AQP isoforms. It has been demonstrated that activation of CFTR by cAMP, increases the water permeability of the cells through the activation of AQP3 (Schreiber et al., 1999; Jourdain et al., 2014). 


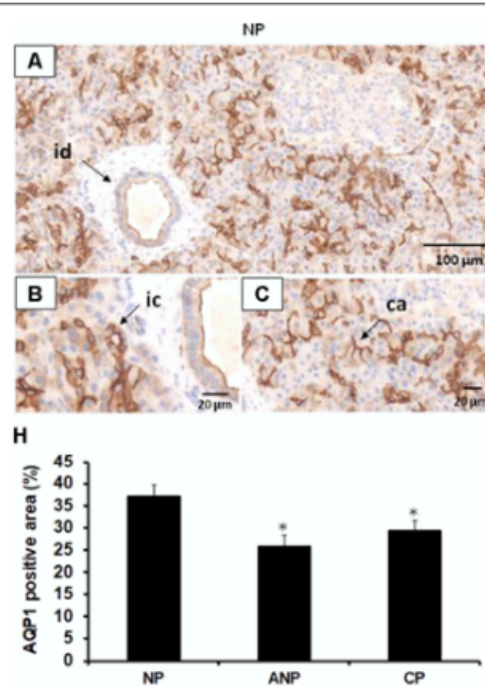

FIGURE 6 | Expression of AQP1 in patients with acute and chronic pancreatitis. Representative histological images show expression and localization of AQP1 in normal human pancreas (NP, A-C) acute necrotizing pancreatitis (ANP, D,E) and chronic pancreatitis (CP, F,G) samples. AQP1 immunoreactivity was detected in inter/intralobular and intercalated ducts, in the acinar and centroacinar cells of the normal pancreas. In contrast, expression of AQP1 strongly decreased in ANP and $\mathrm{CP}$. id, interlobular duct; ic, intercalated duct; ca, centroacinar cells. (H) Intensity of diaminobenzidine staining was measured in pancreas samples by ImageJ software and expressed as percentage of total pancreatic area. ${ }^{*} p \leq 0.05$ vs. normal pancreas, $n=10-12$.

The relation between AQPs and CFTR has been also confirmed in rat epididymis, where CFTR potentiates $A Q P 9$-mediated water permeability (Cheung et al., 2003). Moreover, a direct interaction between AQPs and CFTR has been also observed in Sertoli cells (Jesus et al., 2014a,b). Using double immunostaining we showed for the first time that AQP1 and CFTR are co-localized at the apical membrane of pancreatic ductal cells. Lack of CFTR significantly decreased the expression of AQP1, indicating that CFTR somehow controls the water permeability of ductal cells. Similar results have been found in respiratory epithelial cells, where in the presence of CFTR inhibitor or mutant CFTR the water permeability significantly decreased (Schreiber et al., 1999, 2000; Jourdain et al., 2014) which highlights the significance of this water channel in cystic fibrosis. In contrast, expression of CFTR does not depend on the presence of AQP1, since in the absence of this water channel, strong CFTR staining was detected. This result indicates that the decreased $\mathrm{HCO}_{3}{ }^{-}$secretion in the AQP1 KO mice is not due to the impaired expression of CFTR. Nevertheless, we cannot exclude that although the expression of CFTR did not change but the channel does not work correctly, however, further functional experiments are needed to confirm this hypothesis.

There is more and more evidence that impaired pancreatic fluid secretion plays role in the pathomechanism of pancreatitis (Hegyi and Rakonczay, 2010; Pallagi et al., 2014; Maleth et al., 2015). So in the next step, we investigated whether the lack of AQP1 has any effects on the progression of pancreatitis. The loss of AQP1 itself does not damage the pancreas and does not cause pancreatitis in mice, which assuming the compensating effect of
AQP5; however, induces a more severe disease progression. The involvement of AQP1 in the pathophysiology of pancreatitis has been already raised previously (Kitami et al., 2007). Kitami et al. (2007) have found that AQP1 expression decreased both in the ductal and acinar cells in a cerulein-induced pancreatitis model, which indicate that reduced levels of AQP1 may contribute to exocrine insufficiency. These findings are in accordance with our observation that expression of AQP1 decreased in the ductal and acinar cells of patients with AP or CP. The importance of AQP1 in the exocrine pancreas has been also confirmed by the fact that this water channel is abundantly expressed in the zymogen granules of acinar cells and plays an essential role in zymogen swelling and probably secretion (Cho et al., 2002). AQP12 is also expressed in the zymogen granule of acinar cells and huge amount of this isoform is present in the rough endoplasmic reticulum (Ohta et al., 2009). In the absence of AQP12, high concentration of cholecystokinin octapeptide makes the pancreas more susceptible to pancreatitis, presumably by the aberrant exocytosis of zymogen granules in these mice (Ohta et al., 2009). All of these previous observations indicate that AQP1 plays essential role both in ductal and acinar functions and we speculate that the absence of AQP1 makes the pancreas more sensitive in two ways: (1) ductal fluid secretion is not sufficient and (2) exocytosis of zymogen granules is impaired.

In this study, we provided an overview regarding the expression and role of AQP1 in the physiology and pathophysiology of the pancreas. Our data indicate that AQP1 interacts with the CFTR $\mathrm{Cl}^{-}$channel and takes part in the formation of pancreatic fluid. Moreover, we have found that 
AQP1 plays role in the pathology of pancreatitis. We hypothesize that absence of the channel makes the pancreas more sensitive to pancreatitis, probably due to the decreased pancreatic fluid and $\mathrm{HCO}_{3}{ }^{-}$secretion. Our novel findings not only help to understand the pathomechanism of pancreatitis better, but open up new therapeutic opportunities in the treatment of the disease.

\section{AUTHOR CONTRIBUTIONS}

PP performed microfluorimetric and videomicroscopy experiments. LK, $A Z$, and LP were involved in molecular biology experiments. $A B, M S$, and J-PK performed MRI and JM and ML interpreted the MRI pictures. Genotyping and breeding of $A Q P$ mice were done by EB and EG. Pancreatitis was induced by ZB. $\mathrm{KB}$ and ET did the immunostainings on the human and mice pancreatic samples, respectively, and quantified fluorescence intensity. ZR was involved in data interpretation and edited the manuscript. VV was involved in all of the above mentioned experiments, analyzed the data, and drafted the manuscript. $\mathrm{PH}$ supervised the project and edited the manuscript. All authors approved the final version of the manuscript.

\section{FUNDING}

This study was supported by the National Research, Development and Innovation Office (K109756 to VV, K116634 to PH,

\section{REFERENCES}

Argent, B. E., Arkle, S., Cullen, M. J., and Green, R. (1986). Morphological, biochemical and secretory studies on rat pancreatic ducts maintained in tissueculture. Q. J. Exp. Physiol. 71, 633-648, doi: 10.1113/expphysiol.1986.sp003023

Bedford, J. J., Leader, J. P., and Walker, R. J. (2003). Aquaporin expression in normal human kidney and in renal disease. J. Am. Soc. Nephrol. 14, 2581-2587. doi: 10.1097/01.asn.0000089566.28106.f6

Bodis, B., Nagy, G., Nemeth, N., and Mozsik, G. (2001). Active water selective channels in the stomach: investigation of aquaporins after ethanol and capsaicin treatment in rats. J. Physiol. Paris 95, 271-275. doi: 10.1016/s0928-4257(01) 00037-37

Burghardt, B., Elkjaer, M. L., Kwon, T. H., Racz, G. Z., Varga, G., Steward, M. C., et al. (2003). Distribution of aquaporin water channels AQP1 and AQP5 in the ductal system of the human pancreas. Gut 52, 1008-1016. doi: 10.1136/gut.52. 7.1008

Cheung, K. H., Leung, C. T., Leung, G. P. H., and Wong, P. Y. D. (2003). Synergistic effects of cystic fibrosis transmembrane conductance regulator and aquaporin-9 in the rat epididymis. Biol. Reprod. 68, 1505-1510. doi: 10.1095/biolreprod.102. 010017

Cho, S. J., Sattar, A., Jeong, E. H., Satchi, M., Cho, J. A., Dash, S., et al. (2002). Aquaporin 1 regulates GTP-induced rapid gating of water in secretory vesicles. Proc. Natl. Acad. Sci. U.S.A. 99, 4720-4724. doi: 10.1073/pnas.07208 3499

Criddle, D. N., Murphy, J., Fistetto, G., Barrow, S., Tepikin, A. V., Neoptolemos, J. P., et al. (2006). Fatty acid ethyl esters cause pancreatic calcium toxicity via inositol trisphosphate receptors and loss of ATP synthesis. Gastroenterology 130, 781-793. doi: 10.1053/j.gastro.2005.12.031

Ding, S. P., Li, J. C., and Jin, C. (2003). A mouse model of severe acute pancreatitis induced with caerulein and lipopolysaccharide. World J. Gastroenterol. 9, 584589. doi: 10.3748/wjg.v9.i3.584 and K119938 to ZR), the Economic Development and Innovation Operative Programme Grants (GINOP-2.3.2-152016-00015 and GINOP-2.3.2-15-2016-00020 to PH), the National Research, Development and Innovation Office, by the Ministry of Human Capacities (EFOP 3.6.2-16-2017-00006 to ZR), by Bolyai Postdoctoral Fellowship of the Hungarian Academy of Sciences (HAS) to VV (00531/11/5), the HASUSZ Momentum Grant to PH (LP2014-10/2017), the TÁMOP 4.2.4.A/2-11-1-2012-0001 of the National Excellence Program, the Deutsche Forschungsgemeinschaft (DFG MA 4115/1-2/3, DFG SE 2702/2-1, and GRK 1947;A3), the Federal Ministry of Education and Research (BMBF GANI-MED 03IS2061A and BMBF 0314107, 01ZZ9603, 01ZZ0103, 01ZZ0403, 03ZIK012) and the European Union (EU-FP-7: EPC-TM), V-630-S-1502012/132/133 and PePPP center of excellence MV; ESF/14-BMA55-0045/16.

\section{SUPPLEMENTARY MATERIAL}

The Supplementary Material for this article can be found online at: https://www.frontiersin.org/articles/10.3389/fphys. 2018.00854/full\#supplementary-material

FIGURE S1 | Expression of AQP after various treatments. Capan-1 cells were treated with (A) glycochenodeoxycholic acid (GCDCA), (B) palmitoleic acid (POA), (C) palmitoleic acid ethyl ester and (D) ethanol (EtOH) for 6, 12, 24, and $48 \mathrm{~h}$ and the relative gene expression of AQP1 was investigated by real-time PCR. Data represent mean \pm SEM of three, independent experiments. ${ }^{*} p \leq 0.05$ vs. Control.

Direito, I., Paulino, J., Vigia, E., Brito, M. A., and Soveral, G. (2017) Differential expression of aquaporin-3 and aquaporin -5 in pancreatic ductal adenocarcinoma. J. Surg. Oncol. 115, 980-996. doi: 10.1002/jso.24605

Fernandez-Salazar, M. P., Pascua, P., Calvo, J. J., Lopez, M. A., Case, R. M., Steward, M. C., et al. (2004). Basolateral anion transport mechanisms underlying fluid secretion by mouse, rat and guinea-pig pancreatic ducts. J. Physiol. 556, 415-428. doi: 10.1113/jphysiol.2004.061762

Furuya, S., Naruse, S., Ko, S. B. H., Ishiguro, H., Yoshikawa, T., and Hayakawa, T. (2002). Distribution of aquaporin 1 in the rat pancreatic duct system examined with light- and election-microscopic immunohistochemistry. Cell Tissue Res. 308, 75-86. doi: 10.1007/s00441-002-0527-x

Gabbi, C., Kim, H. J., Hultenby, K., Bouton, D., Toresson, G., Warner, M., et al. (2008). Pancreatic exocrine insufficiency in LXR beta $(-/)$ mice is associated with a reduction in aquaporin-1 expression. Proc. Natl. Acad. Sci. U.S.A. 105, 15052-15057. doi: 10.1073/pnas.0808097105

Hegyi, P., Maleth, J., Venglovecz, V., and Rakonczay, Z. (2011a). Pancreatic ductal bicarbonate secretion: challenge of the acinar acid load. Front. Physiol. 2:36. doi: 10.3389 /fphys.2011.00036

Hegyi, P., Pandol, S., Venglovecz, V., and Rakonczay, Z. Jr. (2011b). The acinarductal tango in the pathogenesis of acute pancreatitis. Gut 60, 544-552. doi: 10.1136/gut.2010.218461

Hegyi, P., and Rakonczay, Z. (2010). Insufficiency of electrolyte and fluid secretion by pancreatic ductal cells leads to increased patient risk for pancreatitis. Am. J. Gastroenterol. 105, 2119-2120. doi: 10.1038/ajg.2010.191

Hegyi, P., and Rakonczay, Z. (2015). The role of pancreatic ducts in the pathogenesis of acute pancreatitis. Pancreatology 15, S13-S17. doi: 10.1016/j. pan.2015.03.010

Hegyi, P., Rakonczay, Z., Gray, M. A., and Argent, B. E. (2004). Measurement of intracellular $\mathrm{pH}$ in pancreatic duct cells: a new method for calibrating the fluorescence data. Pancreas 28, 427-434. doi: 10.1097/00006676-200405000200405012 
Huang, X. W., Huang, L., and Shao, M. H. (2017). Aquaporin 3 facilitates tumor growth in pancreatic cancer by modulating mTOR signaling. Biochem. Biophys. Res. Commun. 486, 1097-1102. doi: 10.1016/j.bbrc.2017.03.168

Hurley, P. T., Ferguson, C. J., Kwon, T. H., Andersen, M. L. E., Norman, A. G., Steward, M. C., et al. (2001). Expression and immunolocalization of aquaporin water channels in rat exocrine pancreas. Am. J. Physiol. Gastrointestinal Liver Physiol. 280, G701-G709. doi: 10.1152/ajpgi.2001.280.4.G701

Itoh, T., Rai, T., Kuwahara, M., Ko, S. B. H., Uchida, S., Sasaki, S., et al. (2005). Identification of a novel aquaporin, AQP12, expressed in pancreatic acinar cells. Biochem. Biophys. Res. Commun. 330, 832-838. doi: 10.1016/j.bbrc.2005.03.046

Jesus, T. T., Bernardino, R. L., Martins, A. D., Sa, R., Sousa, M., Alves, M. G., et al. (2014a). Aquaporin-4 as a molecular partner of cystic fibrosis transmembrane conductance regulator in rat Sertoli cells. Biochem. Biophys. Res. Commun. 446 1017-1021. doi: 10.1016/j.bbrc.2014.03.046

Jesus, T. T., Bernardino, R. L., Martins, A. D., Sa, R., Sousa, M., Alves, M. G., et al. (2014b). Aquaporin-9 is expressed in rat sertoli cells and interacts with the cystic fibrosis transmembrane conductance regulator. IUBMB Life 66, 639-644. doi: $10.1002 /$ iub.1312

Jourdain, P., Becq, F., Lengacher, S., Boinot, C., Magistretti, P. J., and Marquet, P. (2014). The human CFTR protein expressed in CHO cells activates aquaporin-3 in a cAMP-dependent pathway: study by digital holographic microscopy. J. Cell Sci. 127, 546-556. doi: 10.1242/jcs.133629

Judak, L., Hegyi, P., Rakonczay, Z. Jr., Maleth, J., Gray, M. A. and Venglovecz, V. (2014). Ethanol and its non-oxidative metabolites profoundly inhibit CFTR function in pancreatic epithelial cells which is prevented by ATP supplementation. Pflugers Arch. 466, 549-562. doi: 10.1007/s00424-013-1333-x

Kitami, C.-E., Koyama, Y., Nishino, H., Kurosaki, I., Iiai, T., and Hatakeyama, K. (2007). Dynamics of aquaporin 1 and aquaporin 8 in the pancreas: an experimental study with a caerulein-induced pancreatitis model. Acta Med. Biol. 55, 91-101.

Ko, S. B. H., Naruse, S., Kitagawa, M., Ishiguro, H., Furuya, S., Mizuno, N., et al. (2002). Aquaporins in rat pancreatic interlobular ducts. Am. J. Physiol. Gastrointestinal Liver Physiol. 282, G324-G331. doi: 10.1152/ajpgi.00198.2001

Kui, B., Balla, Z., Vasas, B., Vegh, E. T., Pallagi, P., Kormanyos, E. S., et al. (2015). New insights into the methodology of $\mathrm{L}$-arginine-induced acute pancreatitis. PLoS One 10:e0117588. doi: 10.1371/journal.pone.0117588

Levin, M. H., Sullivan, S., Nielson, D., Yang, B. X., Finkbeiner, W. E., and Verkman, A. S. (2006). Hypertonic saline therapy in cystic fibrosis: evidence against the proposed mechanism involving aquaporins. J. Biol. Chem. 281, 25803-25812. doi: $10.1074 /$ jbc.M604332200

Ma, T. H., Jayaraman, S., Wang, K. S., Song, Y. L., Yang, B. X., Li, J., et al. (2001), Defective dietary fat processing in transgenic mice lacking aquaporin-1 water channels. Am. J. Physiol. Cell Physiol. 280, C126-C134. doi: /10.1152/ajpcell. 2001.280.1.C126

Ma, T. H., Yang, B. X., Gillespie, A., Carlson, E. J., Epstein, C. J., and Verkman, A. S. (1998). Severely impaired urinary concentrating ability in transgenic mice lacking aquaporin-1 water channels. J. Biol. Chem. 273, 4296-4299. doi $10.1074 / \mathrm{jbc} .273 .8 .4296$

Madeira, A., Moura, T. F., and Soveral, G. (2015). Aquaglyceroporins: implications in adipose biology and obesity. Cell. Mol. Life Sci. 72, 759-771. doi: 10.1007/s00018-014-1773-2

Maleth, J., Balazs, A., Pallagi, P., Balla, Z., Kui, B., Katona, M., et al. (2015). Alcohol disrupts levels and function of the cystic fibrosis transmembrane conductance regulator to promote development of pancreatitis. Gastroenterology 148, 427-439. doi: 10.1053/j.gastro.2014.11.002

Marinelli, R. A., Pham, L., Agre, P., and LaRusso, N. F. (1997). Secretin promotes osmotic water transport in rat cholangiocytes by increasing aquaporin-1 wate channels in plasma membrane: evidence for a secretin-induced vesicula translocation of aquaporin-1. J. Biol. Chem. 272, 12984-12988. doi: 10.1074/ jbc.272.20.12984

Marinelli, R. A., Tietz, P. S., Pham, L. D., Rueckert, L., Agre, P., and LaRusso, N. F. (1999). Secretin induces the apical insertion of aquaporin-1 water channels in rat cholangiocytes. Am. J. Physiol. 276, G280-G286. doi: 10.1152/ajpgi.1999. 276.1.G280

Marples, D. (2000). Water channels: who needs them anyway? Lancet 355, 1571-1572. doi: 10.1016/s0140-6736(00)02209-1

Mennone, A., Verkman, A. S., and Boyer, J. L. (2002). Unimpaired osmotic water permeability and fluid secretion in bile duct epithelia of AQP1 null mice. Am.
J. Physiol. Gastrointestinal Liver Physiol. 283, G739-G746. doi: 10.1152/ajpgi. 00540.2001

Muili, K. A., Wang, D., Orabi, A. I., Sarwar, S., Luo, Y., Javed, T. A., et al. (2013). Bile acids induce pancreatic acinar cell injury and pancreatitis by activating calcineurin. J. Biol. Chem. 288, 570-580. doi: 10.1074/jbc.M112.428896

Niederau, C., Ferrell, L. D., and Grendell, J. H. (1985). Caerulein-induced acute necrotizing pancreatitis in mice: protective effects of proglumide, benzotript, and secretin. Gastroenterology 88(5 Pt 1), 1192-1204. doi: 10.1016/S00165085(85) 80079-2

Novak, I., and Greger, R. (1988). Electrophysiological study of transport-systems in isolated perfused pancreatic ducts - properties of the basolateral membrane. Pflugers Arch. 411, 58-68. doi: 10.1007/bf00581647

Ohta, E., Itoh, T., Nemoto, T., Kumagai, J., Ko, S. B. H., Ishibashi, K., et al. (2009). Pancreas-specific aquaporin 12 null mice showed increased susceptibility to caerulein-induced acute pancreatitis. Am. J. Physiol. Cell Physiol. 297, C1368C1378. doi: 10.1152/ajpcell.00117.2009

Oshio, K., Watanabe, H., Song, Y., Verkman, A. S., and Manley, G. T. (2004). Reduced cerebrospinal fluid production and intracranial pressure in mice lacking choroid plexus water channel Aquaporin-1. FASEB J. 18, 76-78. doi: 10.1096/fj.04-1711fje

Pallagi, P., Balla, Z., Singh, A. K., Dosa, S., Ivanyi, B., Kukor, Z., et al. (2014). The role of pancreatic ductal secretion in protection against acute pancreatitis in mice*. Crit. Care Med. 42, e177-e188. doi: 10.1097/CCM.0000000000000101

Pallagi, P., Hegyi, P., and Rakonczay, Z. (2015). The physiology and pathophysiology of pancreatic ductal secretion the background for clinicians. Pancreas 44, 1211-1233. doi: 10.1097/mpa.0000000000000421

Pallagi, P., Venglovecz, V., Rakonczay, Z., Borka, K., Korompay, A., Ozsvari, B., et al. (2011). Trypsin reduces pancreatic ductal bicarbonate secretion by inhibiting cftr cl-channels and luminal anion exchangers. Gastroenterology 141 , 2228-2239. doi: 10.1053/j.gastro.2011.08.039

Pallone, T. L., Edwards, A., Ma, T. H., Silldorff, E. P., and Verkman, A. S. (2000). Requirement of aquaporin-1 for NaCl-driven water transport across descending vasa recta. J. Clin. Invest. 105, 215-222. doi: 10.1172/jci8214

Parniczky, A., Kui, B., Szentesi, A., Balazs, A., Szucs, A., Mosztbacher, D. et al. (2016). Prospective, multicentre, nationwide clinical data from 600 cases of acute pancreatitis. PLoS One 11:e0165309. doi: 10.1371/journal.pone. 0165309

Pascua, P., Garcia, M., Fernandez-Salazar, M. P., Hernandez-Lorenzo, M. P., Calvo, J. J., Colledge, W. H., et al. (2009). Ducts isolated from the pancreas of CFTRnull mice secrete fluid. Pflugers Arch. 459, 203-214. doi: 10.1007/s00424-0090704-9

Preston, G. M., Carroll, T. P., Guggino, W. B., and Agre, P. (1992). Appearance of water channels in xenopus oocytes expressing red-cell chip28 protein. Science 256, 385-387. doi: 10.1126/science.256.5055.385

Ribatti, D., Ranieri, G., Annese, T., and Nico, B. (2014). Aquaporins in cancer. Biochim. Biophys. Acta 1840, 1550-1553. doi: 10.1016/j.bbagen.2013.09.025

Roberts, S. K., Yano, M., Ueno, Y., Pham, L., Alpini, G., Agre, P., et al. (1994). Cholangiocytes express the aquaporin chip and transport water via a channel-mediated mechanism. Proc. Natl. Acad. Sci. U.S.A. 91, 13009-13013. doi: 10.1073/pnas.91.26.13009

Rodriguez, A., Catalan, V., Gomez-Ambrosi, J., and Fruhbeck, G. (2011). Aquaglyceroporins serve as metabolic gateways in adiposity and insulin resistance control. Cell Cycle 10, 1548-1556. doi: 10.4161/cc.10.10. 15672

Schnermann, J., Chou, C. L., Ma, T. H., Traynor, T., Knepper, M. A., and Verkman, A. S. (1998). Defective proximal tubular fluid reabsorption in transgenic aquaporin-1 null mice. Proc. Natl. Acad. Sci. U.S.A. 95, 9660-9664. doi: 10.1073/ pnas. 95.16 .9660

Schreiber, R., Nitschke, R., Greger, R., and Kunzelmann, K. (1999). The cystic fibrosis transmembrane conductance regulator activates aquaporin 3 in airway epithelial cells. J. Biol. Chem. 274, 11811-11816. doi: 10.1074/jbc.274.17. 11811

Schreiber, R., Pavenstadt, H., Greger, R., and Kunzelmann, K. (2000). Aquaporin 3 cloned from Xenopus laevis is regulated by the cystic fibrosis transmembrane conductance regulator. FEBS Lett. 475, 291-295. doi: 10.1016/s0014-5793(00) 01689-6

Steinfeld, S., Cogan, E., King, L. S., Agre, P., Kiss, R., and Delporte, C. (2001). Abnormal distribution of aquaporin-5 water channel protein in salivary glands 
from Sjogren's syndrome patients. Lab. Invest. 81, 143-148. doi: 10.1038/ labinvest.3780221

Steward, M. C., Ishiguro, H., and Case, R. M. (2005). Mechanisms of bicarbonate secretion in the pancreatic duct. Annu. Rev. Physiol. 67, 377-409. doi: 10.1146/ annurev.physiol.67.031103.153247

Szucs, A., Marjai, T., Szentesi, A., Farkas, N., Parniczky, A., Nagy, G., et al. (2017). Chronic pancreatitis: multicentre prospective data collection and analysis by the Hungarian Pancreatic Study Group. PLoS One 12:e171420. doi: 10.1371/ journal.pone. 0171420

Takacs, T., Rosztoczy, A., Maleth, J., Rakonczay, Z., and Hegyi, P. (2013). Intraductal acidosis in acute biliary pancreatitis. Pancreatology 13, 333-335. doi: 10.1016/j.pan.2013.05.011

Tani, T., Koyama, Y., Nihei, K., Hatakeyama, S., Ohshiro, K., Yoshida, Y., et al. (2001). Immunolocalization of aquaporin-8 in rat digestive organs and testis. Arch. Histol. Cytol. 64, 159-168. doi: 10.1679/aohc. 64.159

Thomas, J. A., Buchsbaum, R. N., Zimniak, A., and Racker, E. (1979). Intracellular ph measurements in ehrlich ascites tumor-cells utilizing spectroscopic probes generated insitu. Biochemistry 18, 2210-2218. doi: 10.1021/bi0057 $8 \mathrm{a} 012$

Tradtrantip, L., Tajima, M., Li, L., and Verkman, A. S. (2009). Aquaporin water channels in transepithelial fluid transport. J. Med. Invest. 56(Suppl.), 179-184. doi: $10.2152 / \mathrm{jmi} .56 .179$

Tsubota, K., Hirai, S., King, L. S., Agre, P., and Ishida, N. (2001). Defective cellular trafficking of lacrimal gland aquaporin-5 in Sjogren's syndrome. Lancet 357, 688-689. doi: 10.1016/s0140-6736(00)04140-4
Venglovecz, V., Hegyi, P., Rakonczay, Z. Jr., Tiszlavicz, L., Nardi, A., Grunnet, M., et al. (2011). Pathophysiological relevance of apical large-conductance $\mathrm{Ca}(2)+-$ activated potassium channels in pancreatic duct epithelial cells. Gut 60, 361369. doi: 10.1136/gut.2010.214213

Venglovecz, V., Rakonczay, Z., Ozsvari, B., Takacs, T., Lonovics, J., Varro, A., et al. (2008). Effects of bile acids on pancreatic ductal bicarbonate secretion in guinea pig. Gut 57, 1102-1112. doi: 10.1136/gut.2007.134361

Yde, J., Keely, S., Wu, Q., Borg, J. F., Lajczak, N., O’Dwyer, A., et al. (2016). Characterization of AQPs in mouse, rat, and human colon and their selective regulation by bile acids. Front. Nutr. 3:46. doi: 10.3389/fnut.2016.00046

Zhu, C., Chen, Z., and Jiang, Z. Y. (2016). Expression, distribution and role of aquaporin water channels in human and animal stomach and intestines. Int. J. Mol. Sci. 17:1399. doi: 10.3390/ijms17091399

Conflict of Interest Statement: The authors declare that the research was conducted in the absence of any commercial or financial relationships that could be construed as a potential conflict of interest.

Copyright $\odot 2018$ Venglovecz, Pallagi, Kemény, Balázs, Balla, Becskeházi, Gál, Tóth Zvara, Puskás, Borka, Sendler, Lerch, Mayerle, Kühn, Rakonczay and Hegyi. This is an open-access article distributed under the terms of the Creative Commons Attribution License (CC BY). The use, distribution or reproduction in other forums is permitted, provided the original author(s) and the copyright owner(s) are credited and that the original publication in this journal is cited, in accordance with accepted academic practice. No use, distribution or reproduction is permitted which does not comply with these terms. 
Supplementary Figure 1
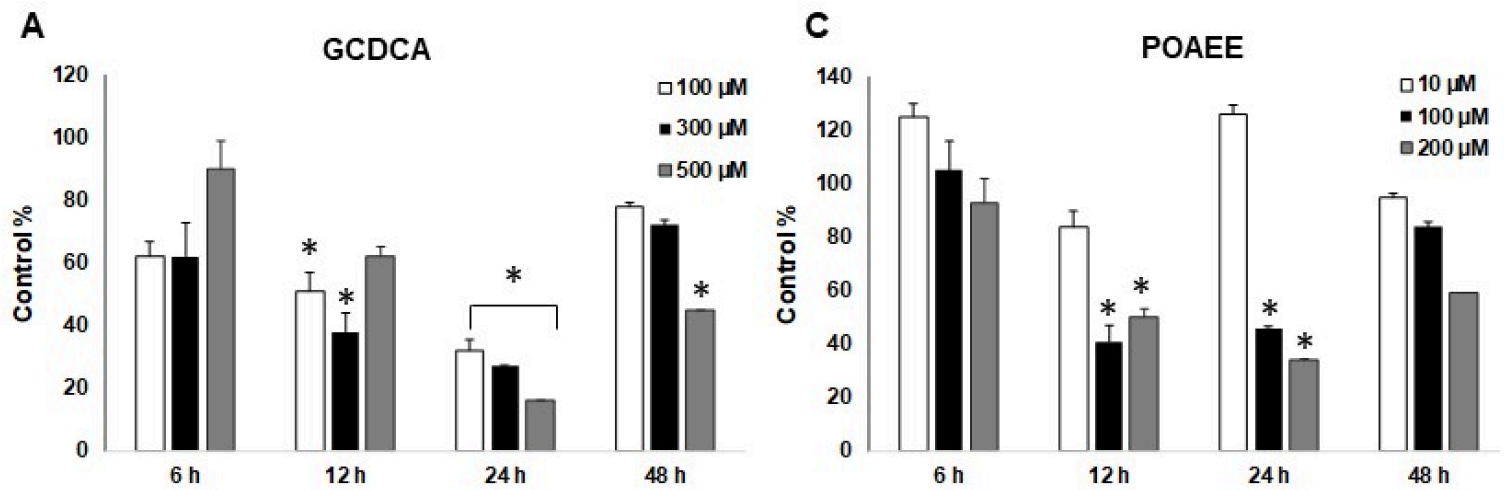

B

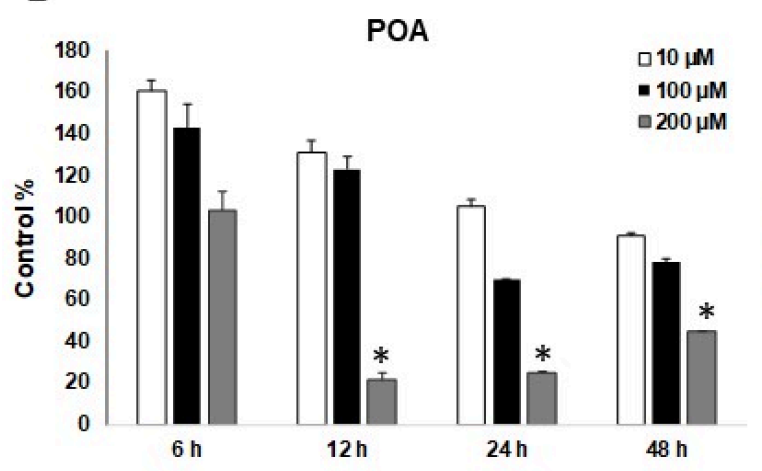

D

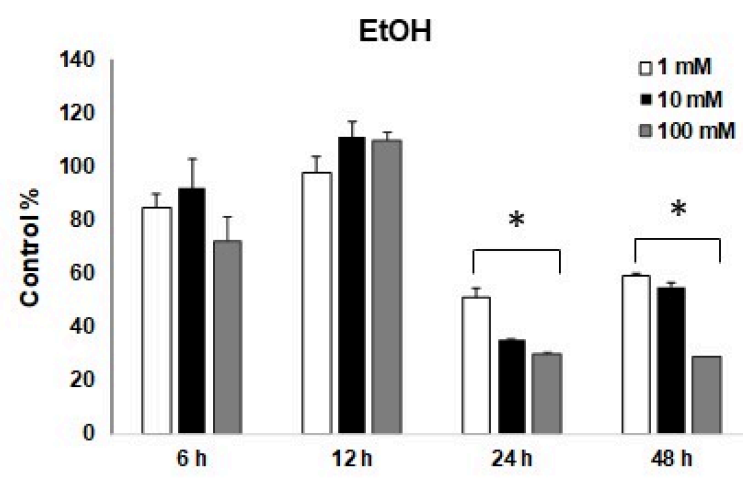

